\title{
EFFECTS OF COAL-MINE DISCHARGES ON THE QUALITY OF THE STONYCREEK RIVER AND ITS TRIBUTARIES, SOMERSET AND CAMBRIA COUNTIES, PENNSYLVANIA
}

U.S. GEOLOGICAL SURVEY

Water-Resources Investigations Report 96-4133

prepared in cooperation with the

SOMERSET CONSERVATION DISTRICT

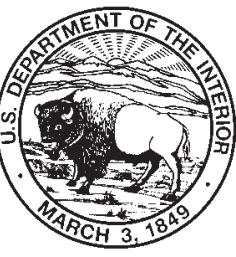




\section{EFFECTS OF COAL-MINE DISCHARGES ON THE QUALITY OF THE STONYCREEK RIVER AND ITS TRIBUTARIES, SOMERSET AND CAMBRIA COUNTIES, PENNSYLVANIA}

by Donald R. Williams, James I. Sams III, and Mary E. Mulkerrin

U.S. GEOLOGICAL SURVEY

Water-Resources Investigations Report 96-4133

prepared in cooperation with the

SOMERSET CONSERVATION DISTRICT

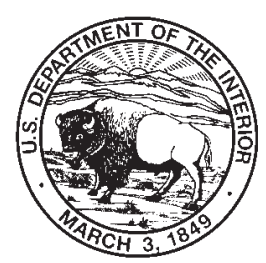

Lemoyne, Pennsylvania

1996 


\title{
U.S. DEPARTMENT OF THE INTERIOR BRUCE BABBITT, Secretary
}

\author{
U.S. GEOLOGICAL SURVEY \\ Gordon P. Eaton, Director
}

For additional information write to:

District Chief

U.S. Geological Survey

840 Market Street

Lemoyne, Pennsylvania 17043-1586
Copies of this report may be purchased from:

U.S. Geological Survey

Branch of Information Services

Box 25286

Denver, Colorado 80225-0286 


\section{CONTENTS}

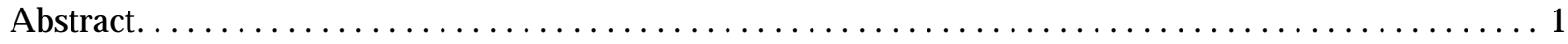

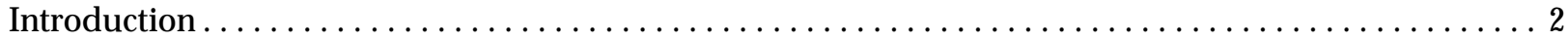

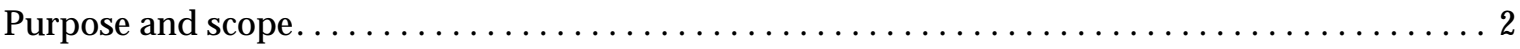

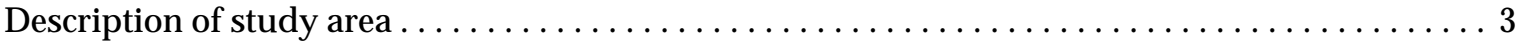

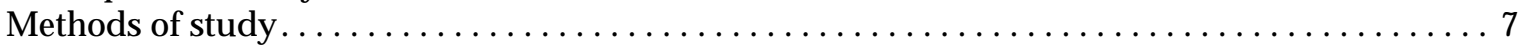

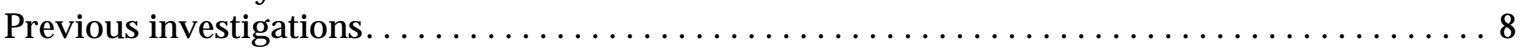

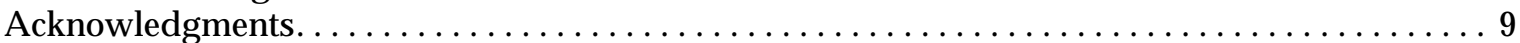

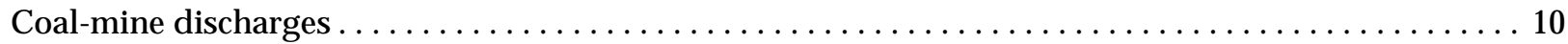

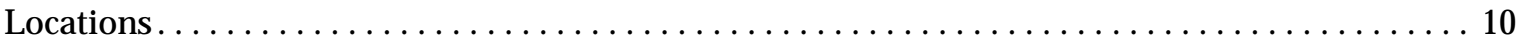

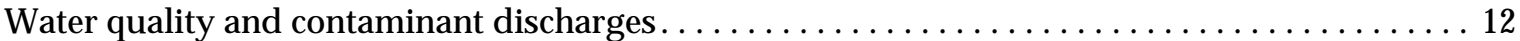

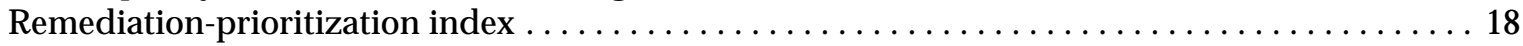

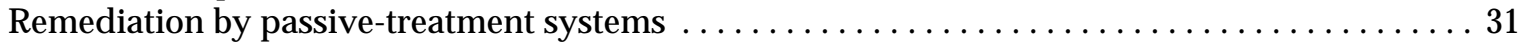

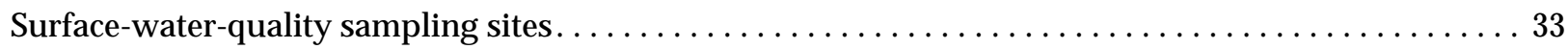

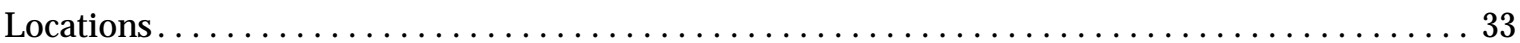

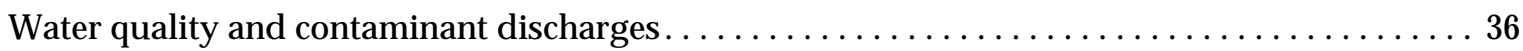

Effects of coal-mine discharge on the quality of Stonycreek River and its tributaries . . . . . . . . . 41

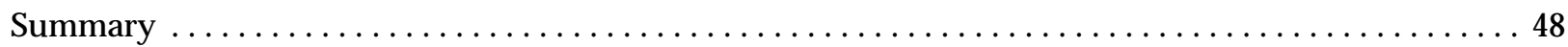

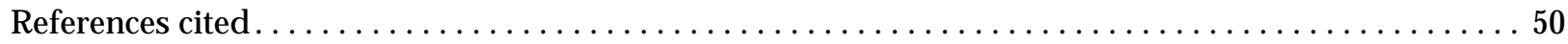

Appendix 1. Geographic information system (GIS) datasets . . . . . . . . . . . . . . . 54

2. Location coordinates and station numbers for sampled mine discharges in the

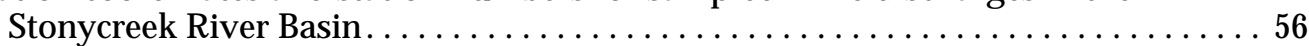

3. Field data and laboratory analyses of mine discharges $\ldots \ldots \ldots \ldots \ldots \ldots \ldots \ldots$

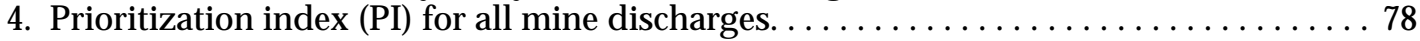

5. Field data and laboratory analyses for surface-water sites $\ldots \ldots \ldots \ldots \ldots \ldots$ 


\section{ILLUSTRATIONS}

Figure 1. Map showing the location of the Stonycreek River Basin. . . . . . . . . . . . .

2. A generalized stratigraphic column of the geologic formations in the Stonycreek

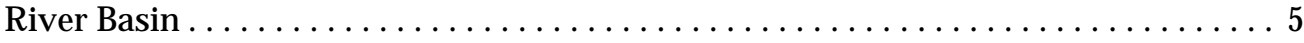

3. Geologic map of the Stonycreek River Basin $\ldots \ldots \ldots \ldots \ldots \ldots \ldots \ldots \ldots \ldots \ldots \ldots$

4. Map showing locations of coal-mine-discharge sites in the Stonycreek River Basin . . . 11

5. Graph showing coal-mine discharges that exceeded federal effluent limits for $\mathrm{pH}$ and concentrations of total iron and total manganese, and arbitrary indicator limits for sulfate and net acidity concentrations. . . . . . . . . . . 13

6-11. Maps showing:

6. Location of the coal-mine-discharge sites in the Shade Creek Basin . . . . . . . 25

7. Location of the coal-mine-discharge sites in the Paint Creek Basin . . . . . . . 26

8. Location of the coal-mine-discharge sites in the Wells Creek Basin . . . . . . . . 27

9. Location of the coal-mine-discharge sites in the Quemahoning Creek Basin . . . . 28

10. Location of the coal-mine-discharge sites in the Oven Run Basin . . . . . . . . . . 29

11. Location of the coal-mine-discharge sites in the Pokeytown Run Basin . . . . . . 30

12. Diagram showing the layout of the Shade passive-treatment system in the Stonycreek River Basin. . . . . . . . . . . . . . . . . . 32

13. Diagram showing a typical cross-sectional view of a successive alkalinity-producing

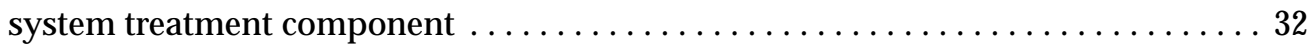

14. Map showing surface-water-quality sampling sites in the Stonycreek River Basin . . . . 35

Figures 15-21. Graphs showing:

15. Specific conductance, $\mathrm{pH}$, and concentrations and discharges of dissolved solids measured in the mainstem and in tributary streams in the Stonycreek

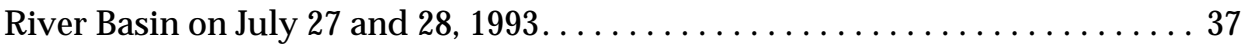

16. Concentrations and discharges of alkalinity and acidity measured in the mainstem and in tributary streams in the Stonycreek River Basin on

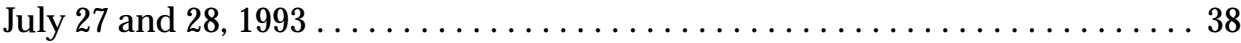

17. Concentrations and discharges of total iron and total manganese measured in the mainstem and in tributary streams in the Stonycreek River Basin on

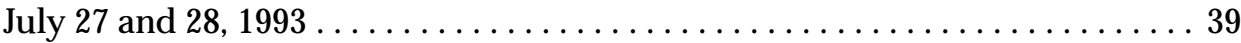

18. Concentrations and discharges of total sulfate measured in the mainstem and in tributary streams in the Stonycreek River Basin on July 27 and 28, 1993 . . . 40

19. Measured total sulfate discharges in tributary streams and measured and calculated total sulfate discharges in the mainstem of the Stonycreek River

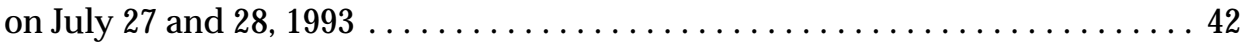

20. The effects of mine discharges 17 and 22 on Wells Creek on September 9, 1993 . . 45

21. The effects of Oven Run and Pokeytown Run on the Stonycreek River on

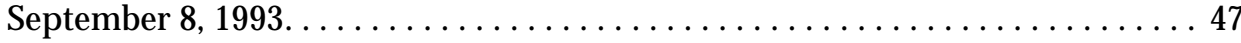




\section{TABLES}

Table 1. Federal effluent limitations for coal-mine drainage $\ldots \ldots \ldots \ldots \ldots \ldots \ldots \ldots \ldots \ldots$

2. Water-quality and quantity changes that occurred downstream of mine-discharge sites 17 and 22 on May 12,1994............................. 14

3. Mine discharges that met federal effluent standards for $\mathrm{pH}$ and concentrations of

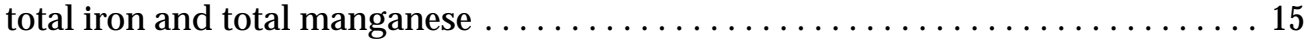

4. Flows, concentrations of total iron and acidity, and iron and acidity discharges and discharge rank for mine discharge sites in the Stonycreek River Basin . . . . . . . 17

5. Unsorted total-iron data and sorted, ranked, and scored total-iron data used for the

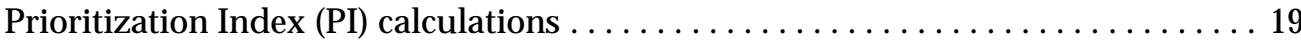

6. Prioritization index (PI) for coal-mine discharges in the Shade Creek Basin. . . . . . . . 21

7. Prioritization index (PI) for coal-mine discharges in the Paint Creek Basin . . . . . . 22

8. Prioritization index (PI) for coal-mine discharges in the Wells Creek Basin . . . . . . . . 23

9. Prioritization index (PI) for coal-mine discharges in the Quemahoning Creek Basin . . 23

10. Prioritization index (PI) for coal-mine discharges in the Oven Run Basin. . . . . . . . 24

11. Prioritization index (PI) for coal-mine discharges in the Pokeytown Run Basin . . . . . 24

12. Surface-water-quality sampling sites in the Stonycreek River Basin . . . . . . . . . . 34

13. Water-quality data for five coal-mine discharges and the receiving streams $\ldots \ldots \ldots 43$

14. Water-quality data collected on September 8, 1993, for Oven Run, Pokeytown Run, and the Stonycreek River above and below where each of the runs flows into

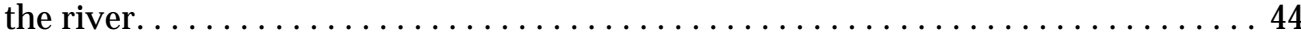


CONVERSION FACTORS, VERTICAL DATUM, AND ABBREVIATED WATER-QUALITY UNITS

Multiply

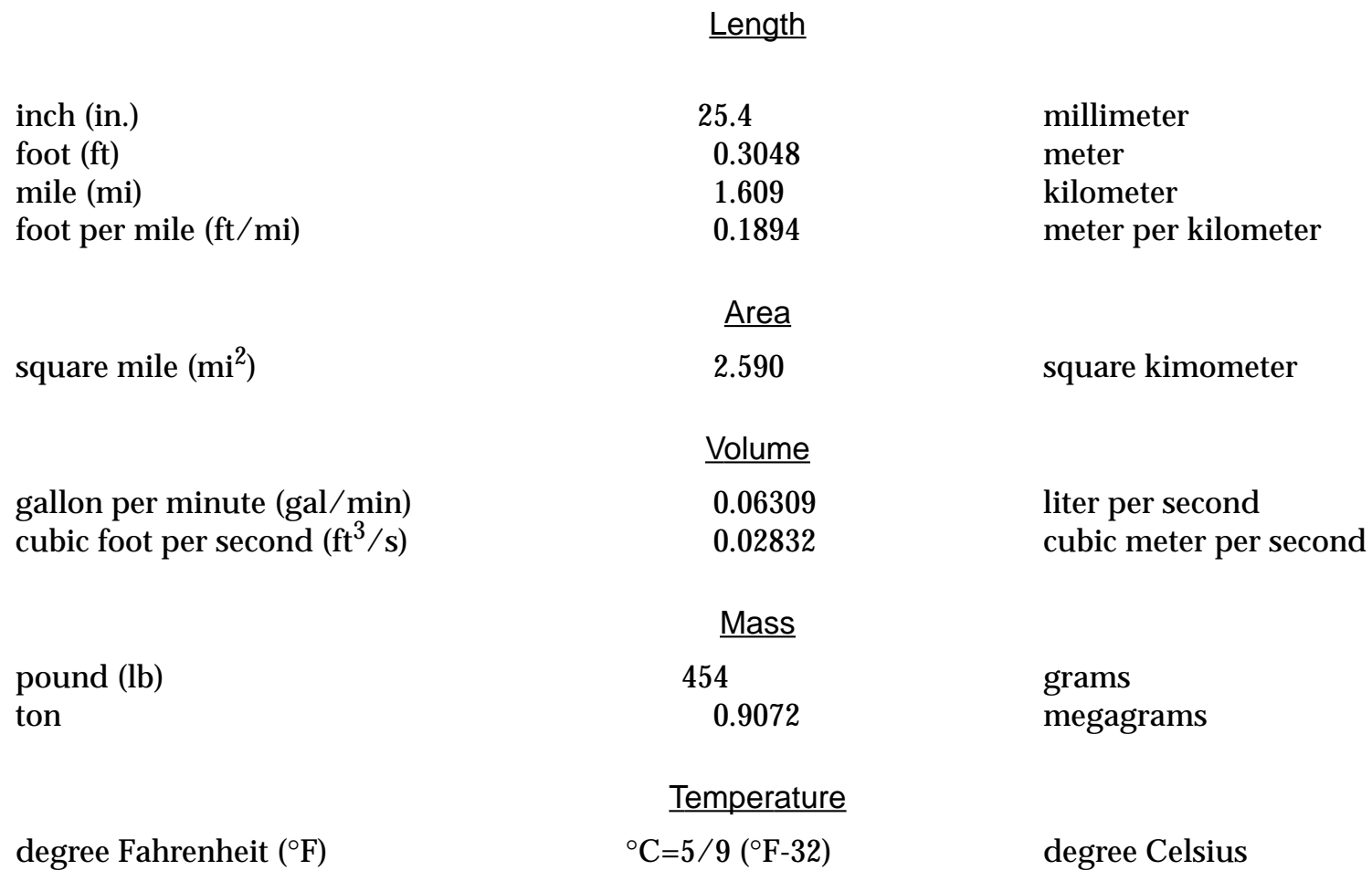

inch (in.)

mile $(\mathrm{mi})$

foot per mile $(\mathrm{ft} / \mathrm{mi})$

${ }^{\circ} \mathrm{C}=5 / 9\left({ }^{\circ} \mathrm{F}-32\right)$ $\underline{\text { To obtain }}$

By

millimeter

meter

kilometer

meter per kilometer liter per second

Sea level: In this report, "sea level" refers to the National Geodetic Vertical Datum of 1929—a geodetic datum derived from a general adjustment of the first-order level nets of the United States and Canada, formerly called Sea Level Datum of 1929.

Abbreviated water-quality units used in report:

micrograms per liter $(\mu \mathrm{g} / \mathrm{L})$

milligrams per liter $(\mathrm{mg} / \mathrm{L})$ 


\title{
EFFECTS OF COAL-MINE DISCHARGES ON THE QUALITY OF THE STONYCREEK RIVER AND ITS TRIBUTARIES, SOMERSET AND CAMBRIA COUNTIES, PENNSYLVANIA
}

\author{
By Donald R. Williams, James I. Sams III, and Mary E. Mulkerrin
}

\begin{abstract}
This report describes the results of a study by the U.S. Geological Survey, done in cooperation with the Somerset Conservation District, to locate and sample abandoned coal-mine discharges in the Stonycreek River Basin, to prioritize the mine discharges for remediation, and to determine the effects of the mine discharges on water quality of the Stonycreek River and its major tributaries. From October 1991 through November 1994, 270 abandoned coal-mine discharges were located and sampled. Discharges from 193 mines exceeded U.S. Environmental Protection Agency effluent standards for pH, discharges from 122 mines exceeded effluent standards for total-iron concentration, and discharges from 141 mines exceeded effluent standards for total-manganese concentration. Discharges from 94 mines exceeded effluent standards for all three constituents. Only 40 mine discharges met effluent standards for $\mathrm{pH}$ and concentrations of total iron and total manganese.
\end{abstract}

A prioritization index (PI) was developed to rank the mine discharges with respect to their loading capacity on the receiving stream. The PI lists the most severe mine discharges in a descending order for the Stonycreek River Basin and for subbasins that include the Shade Creek, Paint Creek, Wells Creek, Quemahoning Creek, Oven Run, and Pokeytown Run Basins.

Passive-treatment systems that include aerobic wetlands, compost wetlands, and anoxic limestone drains (ALD's) are planned to remediate the abandoned mine discharges. The successive alkalinityproducing-system treatment combines ALD technology with the sulfate reduction mechanism of the compost wetland to effectively remediate mine discharge. The water quality and flow of each mine discharge will determine which treatment system or combination of treatment systems would be necessary for remediation.

A network of 37 surface-water sampling sites was established to determine stream-water quality during base flow. A series of illustrations show how water quality in the mainstem deteriorates downstream because of inflows from tributaries affected by acidic mine discharges. From the upstream mainstem site (site 801) to the outflow mainstem site (site 805), $\mathrm{pH}$ decreased from 6.8 to 4.2 , alkalinity was completely depleted by inflow acidities, and total-iron discharges increased from 30 to 684 pounds per day. Total-manganese and total-sulfate discharges increased because neither constituent precipitates readily. Also, discharges of manganese and sulfate entering the mainstem from tributary streams have a cumulative effect.

Oven Run and Pokeytown Run are two small tributary streams significantly affected by acidic mine drainage (AMD) that flow into the Stonycreek River near the town of Hooversville. The Pokeytown Run inflow is about 0.5 mile downstream from the Oven Run inflow. These two streams are the first major source of AMD flowing into the Stonycreek River. Data collected on the Stonycreek River above the Oven Run inflow and below the Pokeytown Run inflow show a decrease in $\mathrm{pH}$ from 7.6 to 5.1, a decrease in alkalinity concentration from 42 to 2 milligrams per liter, an increase in total sulfate discharge from 18 to 41 tons per day, and an increase in total iron discharge from 29 to 1,770 pounds per day. Data collected at three mainstem sites on the Stonycreek River below Oven Run and Pokeytown Run show a progressive deterioration in river water quality from AMD.

Shade Creek and Paint Creek are other tributary streams to the Stonycreek River that have a significant negative effect on water quality of the Stonycreek River. One third the abandoned-mine discharges sampled were in the Shade Creek and Paint Creek Basins. 


\section{INTRODUCTION}

Coal is Pennsylvania's most important mineral resource. In 1993, coal production in Pennsylvania was more than 63 million tons and Somerset and Cambria Counties ranked second (5.6 million tons) and fifth (4.6 million tons), respectively, in the state for total coal produced (Pennsylvania Coal Association, 1994). Much of the Stonycreek River Basin, which is primarily in Somerset County and part in Cambria County, is underlain by low-volatile bituminous coal deposits that are an important economic mineral resource. With the onset of the Industrial Revolution in the late 1800's, extensive commercial mining of these coal resources began with almost no concern for the protection of the land surface and water resources. Consequently, the water quality in the Stonycreek River and its tributaries has been severely degraded for many decades by acid mine drainage (AMD) from abandoned coal mines and coal-refuse piles. The AMD problem has been recognized as one of the most serious and persistent water-quality problems not only in Pennsylvania, but in all of Appalachia, extending from New York to Alabama (Biesecker and George, 1966). Thousands of stream and river miles in Appalachia are currently affected by the input of mine drainage from sites mined and abandoned before strict effluent regulations were implemented (Kleinmann and others, 1988).

Part of the Stonycreek River Basin received an AMD evaluation in the early 1970's in the Operation Scarlift studies (Carson Engineers, 1974). The evaluation indicated the cleanup cost (based on conventional treatment technologies) in that part of the basin would amount to several hundred million dollars, and annual operating costs also would be in the millions of dollars. However, new passive-treatment technologies pioneered by the U.S. Bureau of Mines in the late 1970's and first applied by the mining industry in the 1980's, offer effective, low-cost, low-maintenance remediation.

The Stonycreek-Conemaugh River Improvement Project (SCRIP) association is a coalition of grassroots groups and local resource agencies seeking to restore water quality in the Upper Conemaugh River Basin. This will be accomplished by the combined efforts of government, industry, and the private sectors and by use of new passive-treatment technologies. SCRIP was formed at the request of U.S Congressman John P. Murtha. Its goal is to develop and implement solutions to the AMD problem in the Conemaugh River Basin. SCRIP was instrumental in initiating the cooperative study of the Stonycreek River Basin between the U. S. Geological Survey (USGS) and the Somerset Conservation District.

\section{Purpose and Scope}

This report presents the results of a coal-mine-drainage study in the Stonycreek River Basin in Somerset and Cambria Counties, Pa., from 1992 to 1995. The report describes the locations and instantaneous contaminant loads of 270 mine discharges sampled during low flow throughout the basin and shows the effect that the discharges had on the water quality of the Stonycreek River and its major tributary streams. The report also describes the method used to prioritize the mine discharges for remediation and gives methods for remediation by use of passive-treatment systems. Base-flow samples were collected at 5 mainstem sites and 32 tributary sites in September 1992, July 1993, and May 1994. All 37 sites were sampled each year. To show the specific effect of mine discharges on the receiving streams, five mine discharges were sampled at their point of discharge into the receiving streams, and the receiving streams were sampled above and below these discharges. Also, two streams significantly affected by AMD, Oven Run and Pokeytown Run, were sampled at their point of discharge into the Stonycreek River, and the Stonycreek River was sampled above and below these tributary-stream inflows. 


\section{Description of Study Area}

The Stonycreek River Basin is almost entirely in northern Somerset County in southwestern Pennsylvania with only a small part of the basin in Cambria County (fig. 1). Stonycreek River drains an area of $468 \mathrm{mi}^{2}$. Stonycreek River Basin is in the Allegheny Mountain Section of the Appalachian Plateaus Physiographic Province (Berg and others, 1989). The eastern basin boundary is the Allegheny Front, which is a crest forming the western edge of the Appalachian Mountains of the Ridge and Valley Physiographic Province. The western border of the Stonycreek River Basin is Laurel Ridge. The headwaters of the Stonycreek River rise near the town of Berlin in central Somerset County and flow generally north to Johnstown in Cambria County where it joins the Little Conemaugh River to form the Conemaugh River. The Stonycreek River has a length of $43.4 \mathrm{mi}$ and an average slope of $38 \mathrm{ft} / \mathrm{mi}$ (U.S. Army Corps of Engineers, 1994). Elevations in the basin range from more than 2,900 ft above sea level on both the Allegheny Front and the Laurel Ridge to about 1,150 ft above sea level in the city of Johnstown. Relief throughout the basin is moderate to high. A wide, low flood plain exists at the headwaters of the Stonycreek River. As the river meanders northward, it enters an area of steep flanking hills with relief of 400 to $500 \mathrm{ft}$ near the town of Hooversville; relief increases to a maximum of about $600 \mathrm{ft}$ in Johnstown.

The Stonycreek River Basin contains a large resource of low-volatile bituminous coal. About 14 coal beds of mineable thickness are in the basin. However, the Lower and Upper Kittanning and the Upper Freeport coals have been the most extensively mined. The earliest mining activity in the basin was during the middle to late 1800's and was limited almost entirely to the Pittsburgh Coal bed in the southeastern most part of the basin and the Lower Kittanning Coal bed in the central and northern part of the basin. In the early 1900's, extensive mining of the Upper Kittanning Coal bed began. Surface-mining activities began between 1940 and 1950 and continue to be a major industry throughout the basin.

Rock in the Stonycreek River Basin is sedimentary in origin, and the rock types are primarily sandstone, siltstone, and shale with thin beds of limestone and coal. Folding along the Allegheny Front on the east and Laurel Hill on the west exposes a considerable part of the geologic column, from the Mississippian-Devonian age Rockwell Formation to the Pennsylvania age Monongahela Group. A generalized stratigraphic column showing the units present in the basin is shown in figure 2.

The rocks are divided into eight stratigraphic units: the Rockwell Formation of the MississippianDevonian System; the Burgoon sandstone, Loyalhanna Formation, and Mauch Chunk Formation of the Mississippian System; and the Pottsville Group, Allegheny Group, Conemaugh Group, and Monongahela Group of the Pennsylvanian System. The distribution of stratigraphic units in the basin is shown in figure 3. The Rockwell Formation consists of sandstone, shale, and some red beds. The Burgoon sandstone consists of buff-nonmarine sandstone and conglomerate. The Loyalhanna Formation is a highly crossbedded siliceous limestone. The Mauch Chunk Formation consists of red shale with subordinate sandstone and limestone. The Pottsville Group is composed of the Homewood, Mercer, and Connoquenessing Formations and consists predominantly of sandstone, conglomerate, and thin beds of shale.

The Allegheny and Conemaugh Groups are the two most areally extensive stratigraphic units in the basin. The Allegheny Group is composed of the Freeport, Kittanning, and Clarion Formations. The group consists of sandstone, shale, and discontinuous limestone and coal beds. The Conemaugh Group is composed of the Casselman and Glenshaw Formations and consists primarily of sandstone and shale and lesser amounts of limestone and coal. The Allegheny Group is the major coal-bearing unit in the Stonycreek River Basin, containing the thick Freeport and Kittanning coal beds. In the basin, the Monongahela Group is composed only of the Pittsburgh Formation, which consists of sandstone, limestone, shale, and coal. The Monongahela Group is confined to the hilltops just north of Berlin. This Group contains three workable coal beds-the Pittsburgh coal, the Blue Lick coal (local name), and the Redstone coal. However, in the Stonycreek River Basin, this Group is sparsely represented. 


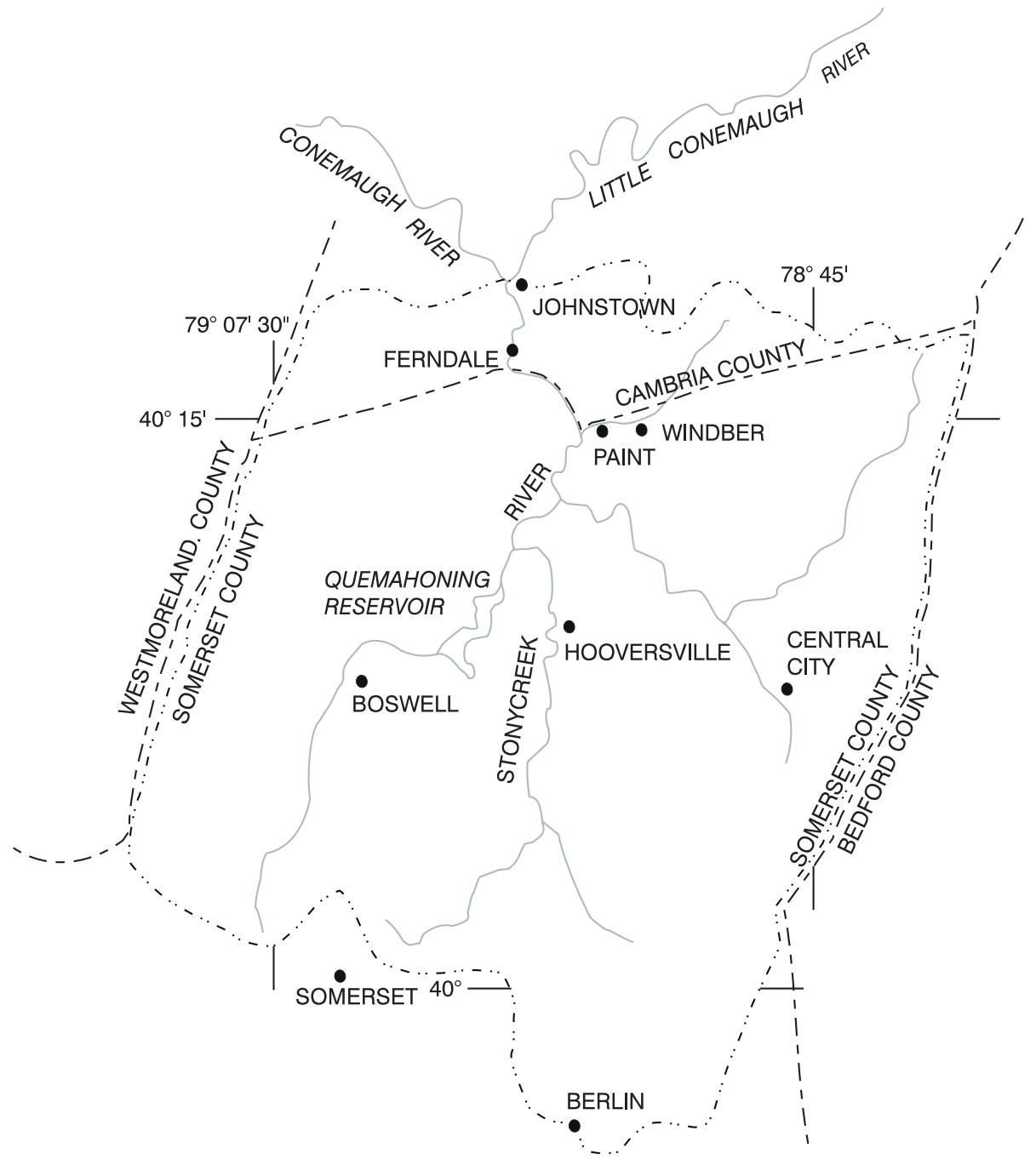

EXPLANATION

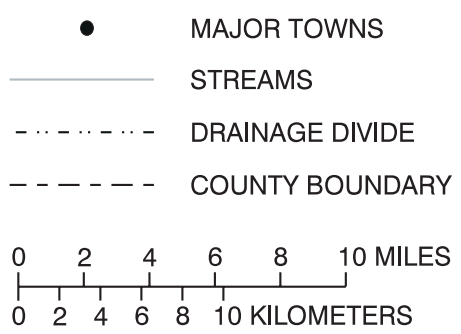

Figure 1. Location of the Stonycreek River Basin. 
GENERALIZED STRATIGRAPHIC COLUMN STONYCREEK RIVER BASIN

\begin{tabular}{|c|c|c|}
\hline \multirow{4}{*}{ 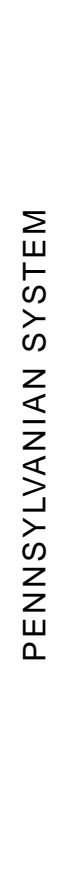 } & 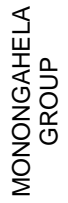 & $\begin{array}{l}\text { Sandstones, limestones, } \\
\text { shales, and thin coal beds }\end{array}$ \\
\hline & 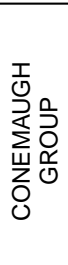 & $\begin{array}{l}\text { Gray and red shales and } \\
\text { sandstones, thin coal beds, } \\
\text { and thin units of limestone }\end{array}$ \\
\hline & 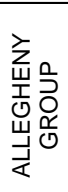 & $\begin{array}{l}\text { Freeport coal } \\
\text { Kittanning coals } \\
\text { Sandstones, shales, } \\
\text { limestones, and coals }\end{array}$ \\
\hline & 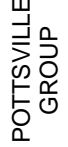 & $\begin{array}{l}\text { Sandstone with shale and } \\
\text { coal beds }\end{array}$ \\
\hline \multirow{3}{*}{ 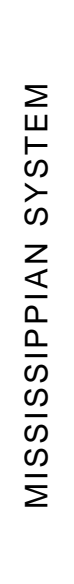 } & 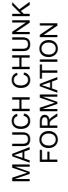 & $\begin{array}{l}\text { Red shale with sandstone } \\
\text { and limestone }\end{array}$ \\
\hline & 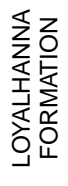 & Siliceous limestone \\
\hline & 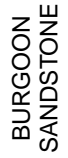 & $\begin{array}{l}\text { Cross-bedded sandstone } \\
\text { with some basal } \\
\text { conglomerate }\end{array}$ \\
\hline 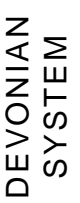 & 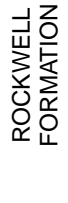 & $\begin{array}{l}\text { Sandstone and } \\
\text { carbonaceous shale }\end{array}$ \\
\hline
\end{tabular}

Figure 2. A generalized stratigraphic column of the geologic formations in the Stonycreek River Basin. 


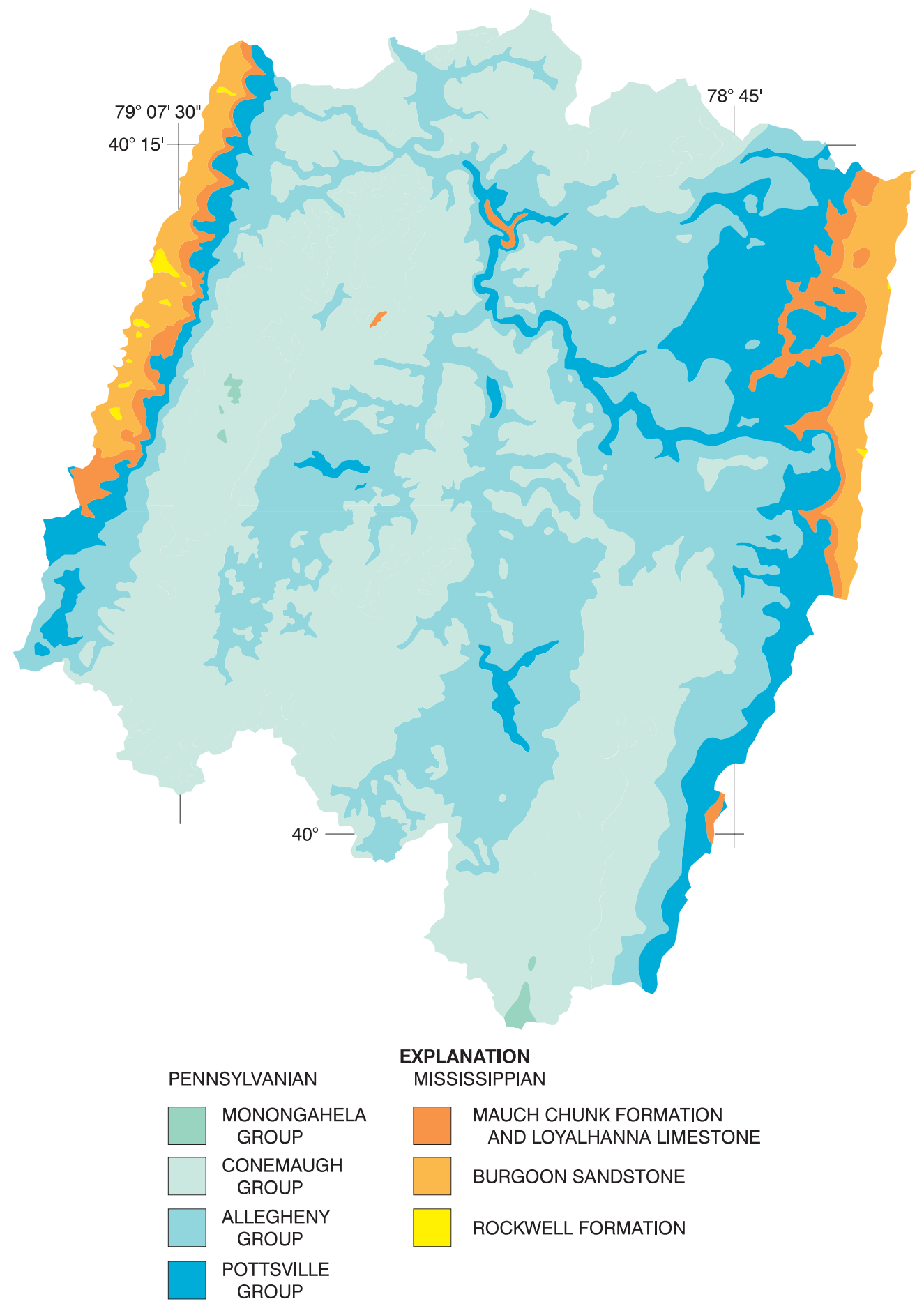

Figure 3. Geologic map of the Stonycreek River Basin (Geology compiled by Berg and others, 1980) 
The climate in the Stonycreek River Basin is humid continental, characterized by warm summers and cold winters. Prevailing winds are from the west and bring most major weather systems that affect the basin. Air currents are mainly from the polar region, but during the summer, air currents from the Gulf of Mexico are frequent and result in warm, humid weather. Annual precipitation from 1926 to 1992 averaged 45.5 in. at Johnstown and from 1960 to 1991 averaged 40.7 in. at Boswell (U.S. Army Corps of Engineers, 1994). Snowfall and resulting snow on the ground throughout the basin tend to be much greater in areas of higher elevation. Average-annual snowfall at Johnstown (elevation approximately 1,200 ft) is $49.9 \mathrm{in}$. and at Boswell (elevation approximately 1,900 ft) is $64.9 \mathrm{in}$. The mean annual temperature at Johnstown during the period $1926-92$ was $51.7^{\circ} \mathrm{F}$. The average monthly temperature at Johnstown varies from a low of $27.9^{\circ} \mathrm{F}$ in January to a high of $72.9^{\circ} \mathrm{F}$ in July. The last frost of the season at Johnstown usually occurs in mid-April to early May; in higher elevations in the basin it could be from mid to late May. The first frost at Johnstown can be expected about mid-September until mid-October, but at higher elevations it has occurred as early as late August.

Agricultural land and forest land collectively account for 90 percent of the total land use throughout the basin (Anderson, 1967). The eastern (Allegheny Front) and western (Laurel Ridge) parts of the basin are the most heavily forested. Surface-mining operations, which affect both agricultural and forest land, are major activities in the basin and account for 4.4 percent of the land use. Residential development, commercial areas, urban areas, light industrial areas, and community parks account for the remaining 5.4 percent. The Stonycreek River Basin is sparsely populated and predominantly rural except near the mouth of the river at Johnstown, where most of the population is concentrated. The largest communities in the basin other than Johnstown and its suburbs include Windber, Berlin, Boswell, Paint, and Central City.

\section{Methods of Study}

One of the most significant challenges of the study was to physically locate the abandoned mine discharges throughout the basin. The mine-discharge locations were determined by four principal methods: (1) from previously published reports and from abandoned mine land (AML) maps supplied by the Bureau of Abandoned Mine Reclamation of the Pennsylvania Department of Environmental Protection (PaDEP); (2) from information obtained from Mine Conservation Inspectors of the PaDEP and River Keepers of the SCRIP organization (River Keepers are local residents who volunteered periodically to walk a section of the banks of the Stonycreek River or its tributaries and provide written reports on the condition of the selected stream segment and locations of mine discharges, sewage outflows, or any other unnatural inflows to the stream); (3) from talking to local residents and farmers familiar with the area and aware of discharges on their property or adjacent properties, (4) and by physically walking along the stream banks of tributary streams and the mainstem in remote areas where mining was known to have occurred. When a mine discharge was found, its location was determined by use of a Global Positioning System (GPS) receiver to record the latitude and longitude of the site to the nearest one tenth of a second. Each mine discharge was sampled where it first came from the ground. At the end of each sampling year, all mine discharges were prioritized and ranked with respect to their loading of selected constituents to the receiving stream. In the following year, the top 30 ranked discharges were resampled.

An initial field reconnaissance of the Stonycreek River Basin was conducted in October and November 1991 to determine the sampling locations of all stream sites. Five mainstem sites were selected on the Stonycreek River and 32 additional sites were selected on tributary streams. All 37 stream sites were sampled during low base flow on September 1 and 2, 1991, and July 27 and 28, 1993, and during high base flow on May 24 and 25, 1994.

The effect of mine discharges on receiving streams was determined by sampling five discharges at their point of inflow to the receiving streams and sampling the receiving streams above and below the mine discharges. The effect of Oven Run and Pokeytown Run on the Stonycreek River was determined by sampling the streams at their point of discharge into the river and sampling the river above and below the stream inflows. 
All water-quality samples were collected and preserved according to USGS standard procedures (Ward and Harr, 1990). Water-quality field measurements for $\mathrm{pH}$, specific conductance, and water temperature were determined by methods described in Fishman and Friedman (1989). Streamflow and mine-discharge flow were measured by methods described in Rantz and others (1982). Laboratory analyses for all water samples included $\mathrm{pH}$, specific conductance, acidity (hot), alkalinity, fluoride, sulfate, total inorganic carbon, total dissolved solids, total and dissolved iron, total and dissolved manganese, and total and dissolved aluminum. Mine discharges that had a field $\mathrm{pH}$ less than 4 were analyzed for ferrous iron. All laboratory analyses were done by the PaDEP laboratory in Harrisburg, Pa., by use of their current methods procedures (Pennsylvania Department of Environmental Resources, 1994a).

To organize the data for the Stonycreek River Basin and provide a means for viewing spatial relations, 14 Geographic Information System (GIS) datasets were developed by use of ARC/INFO 1 software. Datasets are in the export file format. These datasets include hydrography, roads, municipal boundaries, drainage basin boundaries, geology, land use/land cover, state game lands, special protection waters, wetlands, mine discharges, surface-water-quality data, ground-water site inventory (GWSI) data, Pennsylvania water well inventory (PWWI) data, and digital elevation model (DEM) data. All datasets are in the Universal Transverse Mercator (UTM), Zone 17 projection, have measurement units in meters, are clipped to the study-area boundary, and contain a metadata standard describing the dataset. All GIS datasets are described in Appendix 1.

\section{Previous Investigations}

In 1971, the U.S. Environmental Protection Agency (USEPA) conducted a water-supply and waterquality-control study in the Conemaugh River Basin for the U.S. Army Corps of Engineers, Pittsburgh District. The study was initiated to determine needs for flood protection, water supply, recreation, and water-quality control (U.S. Environmental Protection Agency, 1971). The Stonycreek River Basin was one major basin studied within the Conemaugh River Basin.

The USEPA (1972) Wheeling Field Office, Wheeling, W. Va., published a Cooperative Mine Drainage Survey of the Kiskiminetas River Basin that included the Stonycreek River Basin. In the survey, a total of 199 active and abandoned mine-discharge sources were sampled in the Stonycreek River Basin for discharge, total net acidity, total hardness, sulfate, total iron, manganese, and aluminum. Abandoned drift mines are the major source of mine drainage in the Stonycreek River Basin. Shaft mines and mine refuse piles also are major contributors. These three source types contributed a combined acid discharge of $184,145 \mathrm{lb} / \mathrm{d}$, about 86 percent of the total-acid discharge from all 199 sources. Stream water-quality samples were collected on the Stonycreek River and seven tributaries.

A benchmark watershed study of the upper 30 percent of the Stonycreek River Basin was prepared for the Commonwealth of Pennsylvania under the Operation Scarlift program (Carson Engineers, 1974). The report described the origin of AMD in affected tributaries. The report made recommendations for permanent abatement at the mine-discharge sources and gave cost estimates for carrying out each reclamation measure.

From 1979 through 1981, the USGS measured streamflow and sampled water chemistry and aquatic invertebrates at selected stream sites in the coal region that included the Stonycreek River Basin (Herb and others, 1981). The report described information that was useful to surface mine owners, operators, and consulting engineers for the preparation of permit applications, and to regulatory authorities in appraising the adequacy of the applications. From 1976 through 1981, the USGS collected and published waterquality data on Stonycreek River at Ferndale, Pa., for the PaDEP. Data were published annually in the USGS Water-Data Reports PA 76-3 to PA 81-3 (U.S. Geological Survey, 1976-81).

${ }^{1}$ The use of brand names in this report is for identification purposes only and does not constitute endorsement by the U.S. Geological Survey. 
In 1983-86, the USGS collected data on five headwater streams in the Laurel Hill area, three of which were in the Stonycreek River Basin, to determine the effect of acid precipitation on stream water quality (Barker and Witt III, 1990). Sulfate was the dominant precursor for acid formation in precipitation and streamflow. Nitrate was more abundant in snowfalls and contributed to streamflow acidification only during snowmelt.

Water-resources data, climatological data, and quality-assurance data were collected by the USGS in the North Fork Bens Creek Basin, a small subbasin in the Stonycreek River Basin, from 1983 through 1988 (Witt III, 1991).

In 1993, the U.S. Army Corps of Engineers, Pittsburgh District, completed a reconnaissance survey on the lower 4-mi section of the flood-reduction channel on the Stonycreek River (U.S. Army Corps of Engineers, 1993). The survey was conducted to examine the water quality, the channel sediments that might be removed or disturbed, and aquatic-life resources that might be affected by proposed rehabilitation in that section of the flood channel.

A Conemaugh River Basin Reconnaissance Study was published in 1994 by the U.S. Army Corps of Engineers, Pittsburgh District. This study considered a broad array of basin problems, one of which was water-quality degradation with respect to AMD. The study also recommended solutions for identified problem conditions.

The PaDEP publishes a water-quality assessment for Pennsylvania waters on a biennial basis in response to Section 305(b) of the Federal Clean Water Act. The PaDEP 1994 Water-Quality Assessment report for subbasin 18, which includes the Conemaugh River Basin, indicates that the single biggest source of water degradation in the subbasin is coal mining and is responsible for more than 81 percent of the degradation (Pennsylvania Department of Environmental Resources, 1994b).

\section{$\underline{\text { Acknowledgments }}$}

The authors gratefully acknowledge the many individuals residing in the Stonycreek River Basin who took an earnest interest in this project and provided information and assistance in finding many abandoned-mine discharges. A special thanks goes to the Mine Conservation Inspectors of the PaDEP and to the River Keepers of SCRIP who provided information on the location of many mine discharges and assisted field personnel in physically locating the discharges. The authors also acknowledge the interest and cooperation of the many individual landowners, companies, and municipalities throughout the Stonycreek River Basin who provided access to private and public property for the field data collection, and commonly, provided personal escorts for locating secluded mine discharges. 


\section{COAL-MINE DISCHARGES}

Coal mining can result in drainages that have a low $\mathrm{pH}$ and are contaminated with elevated concentrations of iron, manganese, aluminum, sulfate, and acidity. At sites mined since May 4, 1984, drainage chemistry must meet strict effluent quality criteria (Code of Federal Regulations, 1994) (table 1). In an effort to meet these criteria, mining companies commonly treat contaminated drainage by use of chemical methods. In most chemical-treatment systems, metal contaminants are removed through the addition of alkaline chemicals (e.g., sodium hydroxide, calcium hydroxide, calcium oxide, sodium carbonate or ammonia). The chemicals used in these treatment systems can be expensive, especially when required in large quantities. In addition, operation and maintenance costs are associated with aeration and mixing devices, and additional costs are associated with the disposal of metal-laden sludges that accumulate in settling ponds. Water-treatment costs can exceed $\$ 10,000$ per year at sites that are otherwise successfully reclaimed (Hedin and others, 1994). The high costs of chemical water treatment place a serious financial burden on active mining companies and have contributed to bankruptcies of many others.

Table 1. Federal effluent limitations for coal-mine drainage

[Code of Federal Regulations, 1994, Title 40, Part 434, Section 22; concentrations are in micrograms per liter]

\begin{tabular}{lcc}
\hline Element or property & $\begin{array}{c}\text { Maximum for } \\
\text { any } 1 \text { day }\end{array}$ & $\begin{array}{c}\text { Average of daily } \\
\text { values for } 30 \\
\text { consecutive days }\end{array}$ \\
\hline Iron, total & 7,000 & 3,500 \\
Manganese, total & 4,000 & 2,000 \\
$\mathrm{pH}$ & Within the range of 6.0 and 9.0 at all times \\
\hline
\end{tabular}

Although the mining industry throughout the United States spends more than $\$ 1$ million every day to treat effluent waters from active coal mines (Kleinmann, 1989), mine drainage continues to affect stream water quality because of the adverse effects of discharges from abandoned mines, many of which have been inactive for over a century.

The rate and direction of water movement through abandoned mines can be influenced by factors that include precipitation, the structure of the mined coal beds, overburden structure, mine tunnels, air shafts, boreholes, and local collapses. When an underground mine is abandoned, water levels rise until the water eventually overflows to another mine or at the land surface creating an abandoned mine discharge. Mine drainage from abandoned mines and coal refuse piles is the major source of water-quality degradation in the Stonycreek River. Most of the Stonycreek River and particularly the lower half of the river and many of its major tributaries are currently affected by mine drainage from both underground and surface sites. Many sites were mined and abandoned before passage of the Surface Mining Control and Reclamation Act of 1977 (Office of Surface Mining Reclamation and Enforcement, 1993). This Act sets strict compliance standards for surface coal-mining operations and for the surface effects of underground mining.

All mine discharges that were located and sampled for this study were abandoned mine discharges. Mine discharges from active mines are monitored regularly by the PaDEP to determine if the discharges comply with the current Federal and State effluent limitations.

\section{Locations}

Locations of the 270 coal-mine discharges sampled during the study are shown in figure 4 and listed in appendix 2. Methods used to physically locate most of the mine discharges are defined in the Methods of Study section on page 7. After reviewing the information from two previously published reports (U.S. Environmental Protection Agency, 1972; Carson Engineers, 1974) and the AML maps from PaDEP with mine-discharge locations, it was determined that a much more precise method than was used in previous studies was needed to locate mine discharges. A Trimble Navigation GPS Pathfinder system was used to achieve a horizontal accuracy of 3 to $10 \mathrm{ft}$. The exact location coordinates of all 270 mine-discharge locations are given in appendix 2. 


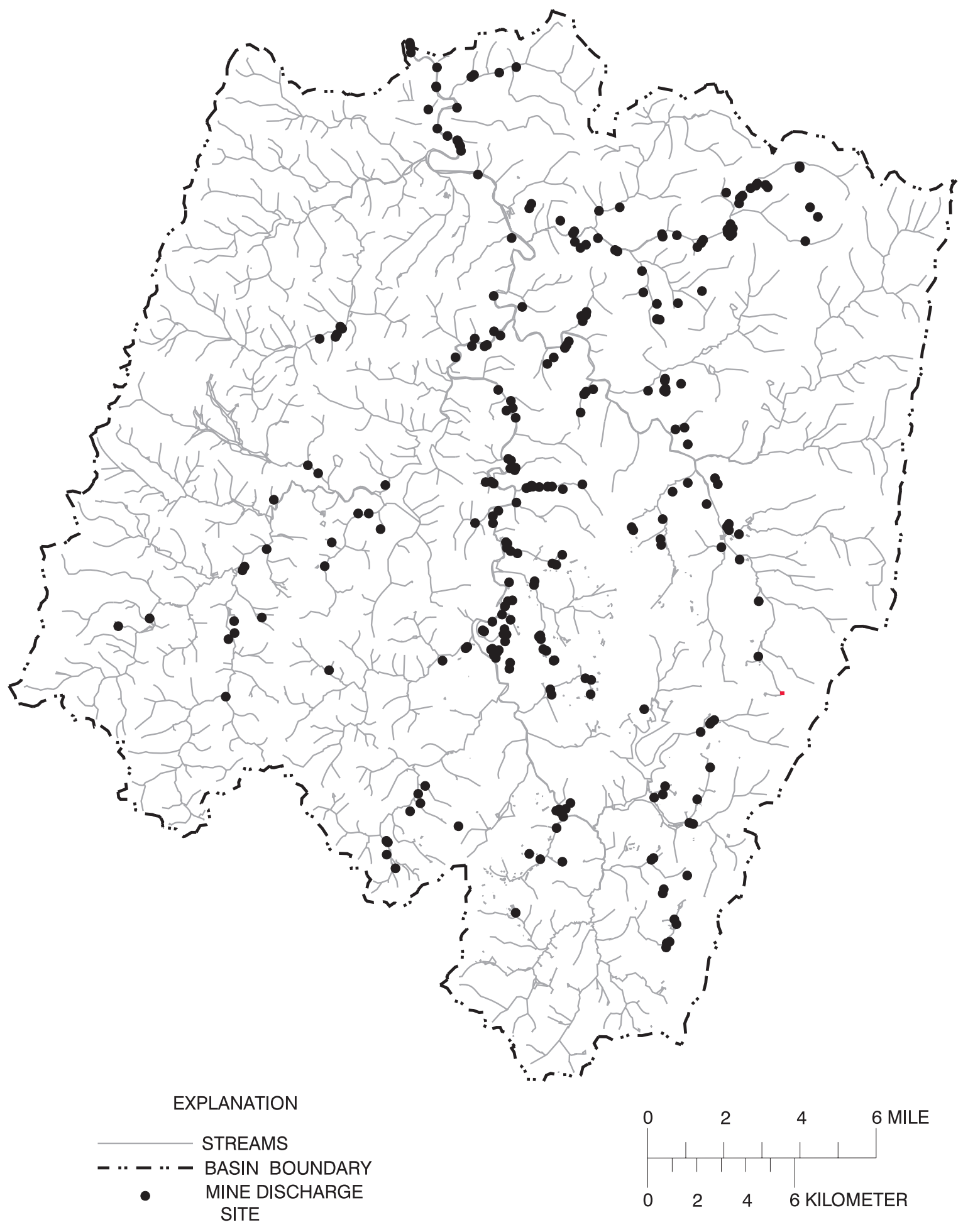

Figure 4. Locations of coal-mine-discharge sites in the Stonycreek River Basin. 


\section{Water Quality and Contaminant Discharges}

Surface and underground coal mining exposes many earth materials to weathering. The physicalchemical breakdown of some materials is accelerated by this weathering process. Pyrite, or iron sulfide $\left(\mathrm{FeS}_{2}\right)$, is commonly present in coal and the adjacent rock strata and is the compound most associated with AMD. Water is also a principal component of the AMD problem, functioning as a reactant in pyrite oxidation, as a reaction medium, and as a transport medium for oxidation products. Pyrite oxidation is described by the following reaction in which pyrite, oxygen, and water form sulfuric acid and ferrous sulfate:

$$
2 \mathrm{FeS}_{2}+7 \mathrm{O}_{2}+2 \mathrm{H}_{2} \mathrm{O}=4 \mathrm{H}^{+}+2 \mathrm{Fe}^{2+}+4 \mathrm{SO}_{4}^{2-}
$$

Oxidation of ferrous iron $\left(\mathrm{Fe}^{2+}\right)$ produces ferric ions $\left(\mathrm{Fe}^{3+}\right)$ according to the following reaction:

$$
2 \mathrm{Fe}^{2+}+1 / 2 \mathrm{O}_{2}+2 \mathrm{H}^{+}=2 \mathrm{Fe}^{3+}+\mathrm{H}_{2} \mathrm{O} .
$$

When the ferric ions react with water, an insoluble ferric hydroxide $\left[\mathrm{Fe}(\mathrm{OH})_{3}\right]$, also called "yellow boy," and more acid are produced:

$$
\mathrm{Fe}^{3+}+3 \mathrm{H}_{2} \mathrm{O}=\mathrm{Fe}(\mathrm{OH})_{3}+3 \mathrm{H}^{+}
$$

The above reactions produce elevated concentrations of the precipitate insoluble ferric hydroxide $\left[\mathrm{Fe}(\mathrm{OH})_{3}\right]$, dissolved sulfate $\left(\mathrm{SO}_{4}^{2-}\right)$, and acid $\left(\mathrm{H}^{+}\right)$. Secondary reactions of the acidic water dissolve many other constituents associated with coal deposits, including manganese, aluminum, zinc, and trace metals such as arsenic, cadmium, and mercury (Tolar, 1982).

High acidities of many mine discharges also can be attributed to the action of the bacterium Thiobacillus ferrooxidans on the pyrite associated with the coal. At near-neutral $\mathrm{pH}$, the oxidation rates of pyrite by air and by T. ferrooxidans are comparable. This stage is typical of freshly exposed coal or refuse, and despite the high concentration of pyrite, the oxidation rate either by oxygen or T. ferrooxidans is low. When a mine discharge is sufficiently alkaline, the acidic water may persist for only a short time before neutralization occurs. However, when the neutralization capacity of the discharge is exceeded, acid begins to accumulate and the $\mathrm{pH}$ decreases. As the $\mathrm{pH}$ decreases, the rate of iron oxidation by oxygen also decreases, but $T$. ferrooxidans catalyze the pyrite oxidation and accelerate acid production, which serves to further lower $\mathrm{pH}$. As the $\mathrm{pH}$ near the pyrite falls to less than 3 , the increased solubility of iron and the decreased rate of ferric hydroxide precipitation significantly increase the overall rate of acid production. Most sampled mine discharges throughout the Stonycreek River Basin that had a pH less than 3 also had very high acidities in addition to high concentrations of iron, manganese, aluminum, and sulfate. The field and laboratory analyses of all samples collected at the 270 mine discharge sites are listed in appendix 3. The number of sampled mine discharges that exceeded effluent limits for $\mathrm{pH}$, total iron, and total manganese concentrations (Code of Federal Regulations, 1994) (table 1) and arbitrary limits for sulfate (U.S. Department of the Interior, 1968) and acidity are shown in figure 5. A pH less than 6.0 was measured in 193 mine discharges, and a pH greater than 9.0 was measured in 1 discharge. Concentrations of total iron greater than 7,000 $\mu \mathrm{g} / \mathrm{L}$ were measured in 122 mine discharges, and 141 mine discharges contained concentrations of total manganese greater than 4,000 $\mu \mathrm{g} / \mathrm{L}$. Effluent limits for $\mathrm{pH}$ and for concentrations of total iron and total manganese were all exceeded in 94 mine discharges. Effluent standards for 1 or 2 of those constituents were exceeded in 140 mine discharges. Sulfate is an excellent indicator of mine drainage because neutralization processes generally do not change the sulfate concentration and the sulfate ion remains in solution. The U.S. Department of Interior (1968) reported that $75 \mathrm{mg} / \mathrm{L}$ of sulfate is an indicator of AMD in streams. Sulfate concentrations exceeded $75 \mathrm{mg} / \mathrm{L}$ in 263 mine discharges. 


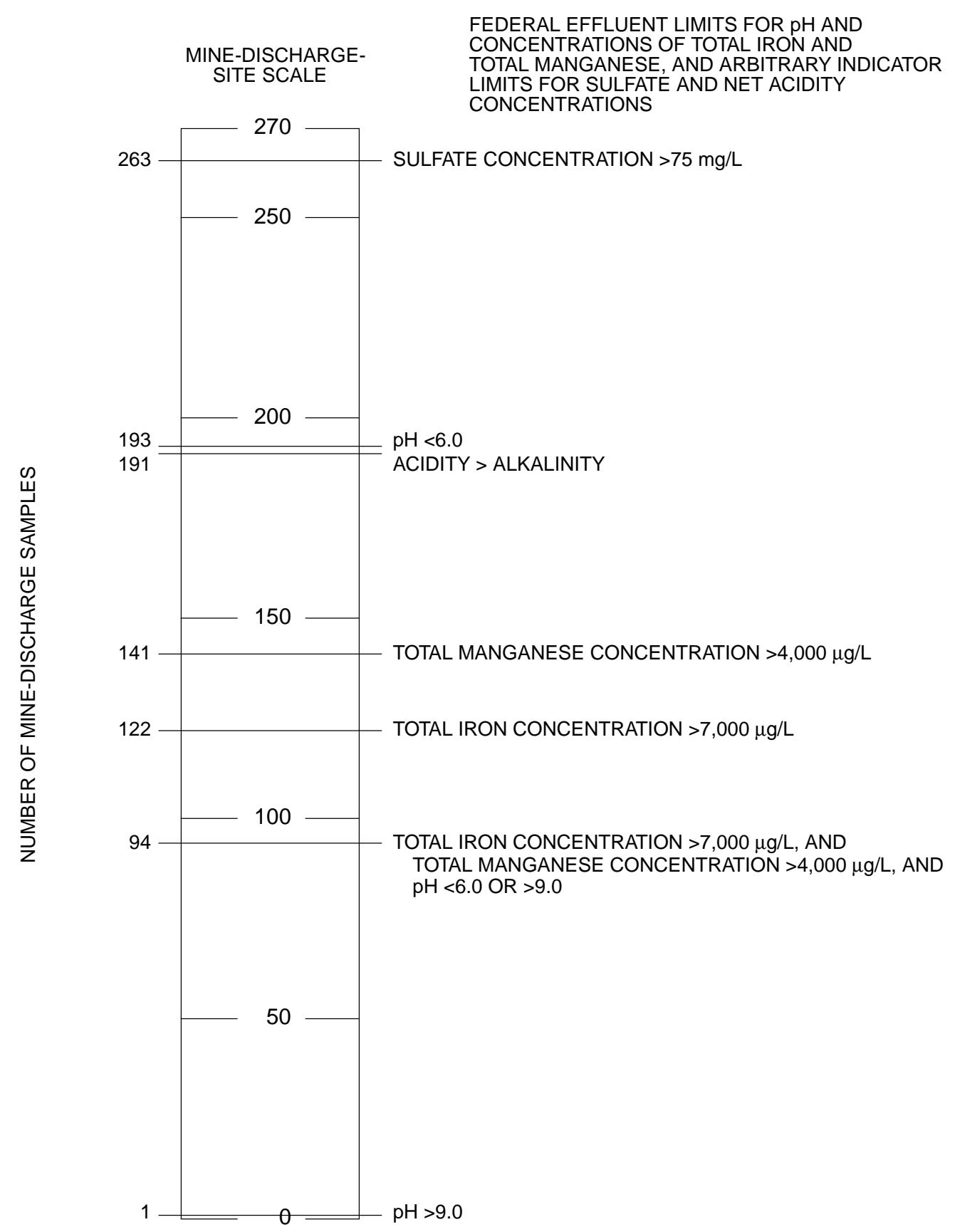

Figure 5. Coal-Mine discharges that exceeded Federal effluent limits for $\mathrm{pH}$ and concentrations of total iron and total manganese, and arbitrary indicator limits for sulfate and net acidity concentrations. 
Acidity concentrations show the severity of a mine discharge. A discharge that is appreciably acidic will be highly aggressive- that is, it will dissolve many minerals in coal mines. The acidity of coal-mine drainage generally arises from free hydrogen ions $\left(\mathrm{H}^{+}\right)$and mineral acidity from dissolved iron, manganese, and aluminum, which can undergo hydrolysis reactions that produce $\mathrm{H}^{+}$. When a mine discharge contains both mineral acidity and alkalinity, the discharge is net acidic if acidity is greater than alkalinity or net alkaline if alkalinity is greater than acidity. Of the mine discharges sampled, 191 were classified as net acidic and the remaining 79 were classified as net alkaline.

Natural processes commonly ameliorate mine discharges and the toxic characteristics of the discharges can decrease because of chemical and biological reactions and by dilution with uncontaminated water. Many of these processes occur as the mine discharge flows on the land surface and is exposed to the air. The data in table 2 show the changes that occurred in water quality and quantity of two mine discharges sampled on the same day at their point of discharge from the ground and at a distance downstream just before the discharges flowed into the receiving stream. Water quality of minedischarge at site 17 showed slight improvement about $400 \mathrm{ft}$ downstream. The flow of mine discharge at site 17 was about the same at both sampling points. The quality of mine discharge at site 22 was considerably improved about 1,000 ft downstream, but dilution appears to have been a significant cause.

Natural processes that ameliorate the quality of mine discharges also can occur before the discharge flows from the ground. When mine water contacts oxygen in the mine voids, iron and manganese can precipitate as hydroxides or oxides, and $\mathrm{pH}$ can increase if the discharge comes in direct contact with carbonate rocks. Of the 270 abandoned-mine discharges sampled, 38 met effluent standards for $\mathrm{pH}$ and concentrations of iron and manganese (table 3). Five of the 38 discharges met secondary drinking-water standards established by USEPA (1994) for $\mathrm{pH}$, iron, manganese, aluminum, and fluoride.

Table 2. Water-quality and quantity changes that occurred downstream of mine-discharge sites 17 and 22 on May 12, 1994

[mg/L, milligram per liter; $\mu \mathrm{g} / \mathrm{L}$, microgram per liter]

\begin{tabular}{|c|c|c|c|c|c|c|}
\hline Site & $\begin{array}{l}\text { Discharge } \\
\text { (cubic feet } \\
\text { per second) }\end{array}$ & $\begin{array}{c}\mathrm{pH} \\
\text { (units) }\end{array}$ & $\begin{array}{c}\text { Iron, } \\
\text { total }(\mu \mathrm{g} / \mathrm{L} \\
\text { as } \mathrm{Fe})\end{array}$ & $\begin{array}{c}\text { Manganese, } \\
\text { total }(\mu \mathrm{g} / \mathrm{L} \\
\text { as } \mathrm{Mn})\end{array}$ & $\begin{array}{c}\text { Acidity, } \\
\text { total heated } \\
(\mu \mathrm{g} / \mathrm{L} \text { as } \\
\left.\mathrm{CaCO}_{3}\right)\end{array}$ & $\begin{array}{c}\text { Sulfate, } \\
\text { total } \\
(\mathrm{mg} / \mathrm{L} \text { as } \\
\left.\mathrm{SO}_{4}\right)\end{array}$ \\
\hline Site 17 at point of discharge from the ground & 2.5 & 3.6 & 990 & 800 & 32 & 200 \\
\hline $\begin{array}{l}\text { Location approximately } 400 \text { feet downstream } \\
\text { of site } 17\end{array}$ & 2.3 & 3.7 & 900 & 760 & 30 & 230 \\
\hline Site 22 at point of discharge from the ground & 1.2 & 3.6 & 21,300 & 7,100 & 172 & 730 \\
\hline $\begin{array}{l}\text { Location approximately 1,000 feet downstream } \\
\text { of site } 22\end{array}$ & 2.5 & 3.4 & 9,300 & 3,700 & 82 & 400 \\
\hline
\end{tabular}


Table 3. Mine discharges that met Federal effluent standards for $\mathrm{pH}$ and concentrations of total iron and total manganese

[U.S. Environmental Protection Agency, 1994; $\mu \mathrm{g} / \mathrm{L}$, microgram per liter; $\mathrm{mg} / \mathrm{L}$, milligrams per liter, <, less than]

\begin{tabular}{|c|c|c|c|c|c|}
\hline $\begin{array}{c}\text { Site } \\
\text { number }\end{array}$ & $\begin{array}{c}\mathrm{pH} \\
\text { (units) }\end{array}$ & $\begin{array}{c}\text { Manganese, } \\
\text { total }(\mu \mathrm{g} / \mathrm{L})\end{array}$ & $\begin{array}{c}\text { Iron, } \\
\text { total } \\
(\mu \mathrm{g} / \mathrm{L})\end{array}$ & $\begin{array}{l}\text { Aluminum, } \\
\text { total }(\mu \mathrm{g} / \mathrm{L})\end{array}$ & $\begin{array}{c}\text { Fluoride } \\
\text { (mg/L) }\end{array}$ \\
\hline 50 & 7.1 & 330 & 24 & & \\
\hline 61 & 6.7 & 2,000 & 150 & & \\
\hline 64 & 6.4 & 2,900 & 1,700 & & \\
\hline 66 & 6.8 & 500 & 260 & & \\
\hline 68 & 6.7 & 130 & 1,400 & & \\
\hline 86 & 6.6 & 610 & 500 & & \\
\hline 88 & 6.5 & 10 & 60 & & \\
\hline 91 & 6.8 & 120 & 88 & & \\
\hline 96 & 6.3 & 610 & 460 & & \\
\hline 121 & 6.0 & 760 & 940 & & \\
\hline 123 & 6.4 & 170 & 50 & & \\
\hline 135 & 6.6 & 1,200 & 140 & & \\
\hline 136 & 6.6 & 1,800 & 170 & & \\
\hline 145 & 6.2 & 70 & 280 & & \\
\hline 146 & 6.7 & 1,600 & 120 & & \\
\hline 151 & 6.5 & 3,000 & 260 & & \\
\hline 152 & 6.5 & 40 & 100 & & \\
\hline 153 & 6.3 & 230 & 320 & & \\
\hline 171 & 6.6 & 950 & 510 & & \\
\hline 193 & 6.9 & 1,400 & 130 & & \\
\hline${ }^{1} 195$ & 7.1 & 100 & 10 & $<130$ & $<0.2$ \\
\hline${ }^{1} 196$ & 6.8 & 30 & 10 & $<130$ & $<.2$ \\
\hline 197 & 7.2 & 1,900 & 79 & & \\
\hline 199 & 7.1 & 230 & 170 & & \\
\hline 202 & 6.1 & 150 & 86 & & \\
\hline 211 & 6.6 & 1,200 & 1,600 & & \\
\hline 224 & 6.4 & 830 & 3,900 & & \\
\hline 229 & 6.2 & 2,200 & 380 & & \\
\hline 230 & 6.1 & 4,000 & 2,000 & & \\
\hline 243 & 6.3 & 2,000 & 43 & & \\
\hline 244 & 6.3 & 220 & 17 & & \\
\hline 245 & 6.0 & 210 & 120 & & \\
\hline${ }^{1} 246$ & 6.4 & 20 & 240 & $<130$ & $<.2$ \\
\hline${ }^{1} 247$ & 6.6 & 490 & 840 & 150 & $<.2$ \\
\hline 257 & 6.9 & 570 & 33 & & \\
\hline 259 & 6.3 & 180 & 190 & & \\
\hline 268 & 6.3 & 700 & 680 & & \\
\hline${ }^{1} 270$ & 6.6 & 110 & 10 & 197 & .2 \\
\hline
\end{tabular}

${ }^{1}$ Discharges that met U.S. Environmental Protection Agency secondary drinking water standards for aluminum and fluoride. 
The flow rate of a mine discharge is one of the most important factors when determining contaminant discharges. This is illustrated in table 4 . The first set of data on the top left side of the table represents the top 10 percent ( 27 discharges) of the 270 mine discharges with respect to the largest total iron concentrations. The sites are sorted from highest concentration to lowest concentration of total iron. The "DISCHARGE RANK" column represents the rank of the corresponding discharge for each site from highest measured instantaneous discharge to lowest measured instantaneous discharge of all 270 mine discharges. For example, mine discharge at site 20 contained the highest measured total-iron concentration $(4,750,000 \mu \mathrm{g} / \mathrm{L})$ of all 270 mine discharges, but the iron discharge of $39.9 \mathrm{lb} / \mathrm{d}$ ranked 26th of all 270 mine discharges. Mine discharge at site 122 contained the fourth highest measured iron concentration $(690,000 \mu \mathrm{g} / \mathrm{L})$, but its discharge of only $1.66 \mathrm{lb} / \mathrm{d}$ ranked that mine discharge 107th of the 270 mine discharges.

On the top right side of table 4, the data are sorted with respect to total-iron discharges, with the highest measured discharge at the top of the data group in the column marked "Discharge, lb/ $\mathrm{d}$ " and the lowest measured discharge at the bottom. In this data group, mine discharge at site 16 contained the largest total iron discharge $(1,700 \mathrm{lb} / \mathrm{d})$, but the concentration ranked only 41 of the 270 discharges. The reason for the highest measured total iron discharge was because of the very large flow $(2,250 \mathrm{gal} / \mathrm{min})$ in addition to a large concentration $(63,000 \mu \mathrm{g} / \mathrm{L})$. Mine discharges at sites 149 and 242 ranked very high in both iron discharge rank and iron concentration rank because both mine discharges contained high totaliron concentrations and high flows.

The bottom half of table 4 shows discharge ranks and concentration ranks for acidities that were sorted on the basis of acidity concentrations and acidity discharges. Site 242 ranked second of all 270 sites in acidity discharge rank and acidity concentration rank. The iron and acidity columns labeled "Discharge, $\mathrm{lb} / \mathrm{d}$ " on the right side of table 4 gives the 27 mine discharges that are contributing most of the contaminant discharges of total iron and total acidity to the receiving streams.

The next section in this report integrates discharges of total iron, total manganese, dissolved aluminum, acidity, and sulfate to prioritize all sampled mine discharges for remediation. 
Table 4. Flows, concentrations of total iron and acidity, and iron and acidity discharges and discharge rank for mine discharge sites in the Stonycreek River Basin

[gal/min, gallon per minute; $\mu \mathrm{g} / \mathrm{L}$, microgram per liter; lb/d, pound per day; mg/L, milligram perliter; <, less than]

\begin{tabular}{|c|c|c|c|c|}
\hline Site & $\begin{array}{c}\text { Flow } \\
\text { (gal/min) }\end{array}$ & $\begin{array}{l}\text { Iron } \\
(\mu \mathrm{g} / \mathrm{L})\end{array}$ & $\begin{array}{c}\text { Discharge } \\
\text { (lb/d) }\end{array}$ & $\begin{array}{l}\text { Discharge } \\
\text { rank }\end{array}$ \\
\hline 20 & 0.7 & $4,750,000$ & 39.9 & 26 \\
\hline 242 & 22 & $2,750,000$ & 726 & 4 \\
\hline 79 & 2.0 & $1,300,000$ & 31.2 & 31 \\
\hline 122 & .2 & 690,000 & 1.66 & 107 \\
\hline 165 & 18 & 320,000 & 69.1 & 17 \\
\hline 149 & 310 & 300,000 & 1,120 & 2 \\
\hline 228 & .1 & 220,000 & .26 & 164 \\
\hline 141 & 48 & 210,000 & 121 & 12 \\
\hline 24 & 3 & 210,000 & 7.56 & 68 \\
\hline 158 & .5 & 200,000 & 1.20 & 118 \\
\hline 192 & 2.1 & 190,000 & 4.79 & 76 \\
\hline 174 & 7.5 & 180,000 & 16.2 & 42 \\
\hline 180 & 25 & 180,000 & 54.0 & 23 \\
\hline 191 & 5 & 180,000 & 10.8 & 54 \\
\hline 219 & 18 & 160,000 & 34.6 & 29 \\
\hline 166 & 13 & 150,000 & 23.4 & 34 \\
\hline 142 & 2.5 & 140,000 & 4.20 & 81 \\
\hline 57 & 1.6 & 130,000 & 2.50 & 91 \\
\hline 80 & .4 & 130,000 & .62 & 139 \\
\hline 94 & 2.5 & 130,000 & 3.90 & 83 \\
\hline 125 & 225 & 130,000 & 351 & 6 \\
\hline 225 & 60 & 120,000 & 86.4 & 14 \\
\hline 184 & 45 & 120,000 & 64.8 & 20 \\
\hline 127 & 1.3 & 110,000 & 1.72 & 105 \\
\hline 176 & 330 & 110,000 & 436 & 5 \\
\hline 148 & .2 & 100,000 & .24 & 165 \\
\hline 179 & 7.5 & 95,000 & 8.55 & 61 \\
\hline Site & $\begin{array}{c}\text { Flow } \\
\text { (gal/min) }\end{array}$ & $\begin{array}{l}\text { Acidity } \\
\text { (mg/L) }\end{array}$ & $\begin{array}{c}\text { Discharge } \\
(\mathrm{lb} / \mathrm{d})\end{array}$ & $\begin{array}{l}\text { Discharge } \\
\text { rank }\end{array}$ \\
\hline 20 & 0.7 & 19,700 & 165 & 37 \\
\hline 242 & 22 & 12,200 & 3,230 & 2 \\
\hline 79 & 2.0 & 3,940 & 94.6 & 50 \\
\hline 122 & .2 & 3,620 & 8.69 & 121 \\
\hline 165 & 18 & 1,600 & 345 & 24 \\
\hline 141 & 48 & 1,300 & 751 & 6 \\
\hline 125 & 225 & 1,180 & 3,180 & 3 \\
\hline 142 & 2.5 & 1,120 & 33.6 & 79 \\
\hline 219 & 18 & 940 & 203 & 32 \\
\hline 227 & 7.5 & 940 & 84.6 & 55 \\
\hline 117 & 21 & 934 & 235 & 30 \\
\hline 124 & 18 & 866 & 187 & 35 \\
\hline 158 & .5 & 850 & 5.10 & 136 \\
\hline 24 & 3 & 840 & 30.2 & 83 \\
\hline 188 & 51 & 820 & 501 & 16 \\
\hline 180 & 25 & 820 & 246 & 28 \\
\hline 166 & 13 & 820 & 128 & 44 \\
\hline 73 & 1.6 & 780 & 15.0 & 102 \\
\hline 118 & .3 & 734 & 2.64 & 161 \\
\hline 60 & 6.4 & 720 & 55.3 & 63 \\
\hline 94 & 2.5 & 714 & 21.4 & 94 \\
\hline 80 & .4 & 700 & 3.36 & 154 \\
\hline 140 & 27 & 684 & 222 & 31 \\
\hline 208 & 374 & 680 & 3,050 & 4 \\
\hline 59 & 3.1 & 660 & 24.6 & 88 \\
\hline 3 & 155 & 630 & 1,170 & 7 \\
\hline 204 & 60 & 620 & 446 & 20 \\
\hline
\end{tabular}

\begin{tabular}{|c|c|c|c|c|}
\hline Site & $\begin{array}{c}\text { Flow } \\
\text { (gal/min) }\end{array}$ & $\begin{array}{l}\text { Iron } \\
(\mu \mathrm{g} / \mathrm{L})\end{array}$ & $\begin{array}{l}\text { Discharge } \\
(\mathrm{lb} / \mathrm{d})\end{array}$ & $\begin{array}{c}\text { Concen- } \\
\text { tration } \\
\text { rank }\end{array}$ \\
\hline 16 & 2,250 & 63,000 & 1,700 & 41 \\
\hline 149 & 310 & 300,000 & 1,120 & 6 \\
\hline 19 & 1,780 & 41,000 & 876 & 57 \\
\hline 242 & 22 & $2,750,000$ & 726 & 2 \\
\hline 176 & 330 & 110,000 & 435 & 25 \\
\hline 125 & 225 & 130,000 & 351 & 21 \\
\hline 178 & 1,620 & 17,000 & 330 & 93 \\
\hline 173 & 470 & 34,000 & 192 & 68 \\
\hline 110 & 449 & 30,000 & 162 & 75 \\
\hline 3 & 155 & 75,000 & 140 & 32 \\
\hline 4 & 348 & 30,000 & 125 & 76 \\
\hline 141 & 48 & 210,000 & 121 & 8 \\
\hline 81 & 1,400 & 6,900 & 116 & 124 \\
\hline 225 & 60 & 120,000 & 86.4 & 22 \\
\hline 109 & 180 & 39,000 & 84.2 & 60 \\
\hline 22 & 224 & 30,000 & 80.6 & 74 \\
\hline 165 & 18 & 320,000 & 69.1 & 5 \\
\hline 15 & 96 & 60,000 & 69.1 & 45 \\
\hline 97 & 197 & 28,000 & 66.2 & 80 \\
\hline 184 & 45 & 120,000 & 64.8 & 23 \\
\hline 38 & 78 & 66,000 & 61.8 & 40 \\
\hline 180 & 25 & 180,000 & 54.0 & 13 \\
\hline 205 & 75 & 52,000 & 46.8 & 49 \\
\hline 95 & 981 & 3,500 & 41.2 & 155 \\
\hline 248 & 114 & 30,000 & 41.0 & 77 \\
\hline 20 & $<1$ & $4,750,000$ & 39.9 & 1 \\
\hline 55 & 45 & 72,000 & 38.9 & 35 \\
\hline Site & $\begin{array}{c}\text { Flow } \\
\text { (gal/min) }\end{array}$ & $\begin{array}{l}\text { Acidity } \\
\text { (mg/L) }\end{array}$ & $\begin{array}{l}\text { Discharge } \\
(\mathrm{lb} / \mathrm{d})\end{array}$ & $\begin{array}{c}\text { Concen- } \\
\text { tration } \\
\text { rank }\end{array}$ \\
\hline 16 & 2,250 & 250 & 6,750 & 61 \\
\hline 242 & 22 & 12,200 & 3,230 & 2 \\
\hline 125 & 225 & 1,180 & 3,190 & 7 \\
\hline 208 & 374 & 680 & 3,050 & 24 \\
\hline 149 & 310 & 540 & 2,010 & 30 \\
\hline 19 & 1,780 & 74 & 1,580 & 132 \\
\hline 3 & 155 & 630 & 1,170 & 26 \\
\hline 4 & 348 & 270 & 1,130 & 55 \\
\hline 14 & 799 & 88 & 844 & 119 \\
\hline 141 & 48 & 1,300 & 751 & 6 \\
\hline 81 & 1,400 & 44 & 739 & 156 \\
\hline 189 & 539 & 100 & 647 & 101 \\
\hline 176 & 330 & 162 & 642 & 76 \\
\hline 110 & 449 & 100 & 539 & 102 \\
\hline 22 & 224 & 200 & 538 & 66 \\
\hline 188 & 51 & 820 & 502 & 15 \\
\hline 103 & 436 & 92 & 481 & 111 \\
\hline 104 & 200 & 194 & 466 & 68 \\
\hline 63 & 277 & 140 & 465 & 85 \\
\hline 204 & 60 & 620 & 446 & 27 \\
\hline 97 & 197 & 186 & 440 & 71 \\
\hline 38 & 78 & 442 & 414 & 40 \\
\hline 95 & 981 & 30 & 353 & 168 \\
\hline 165 & 18 & 1,600 & 346 & 5 \\
\hline 164 & 97 & 260 & 303 & 56 \\
\hline 15 & 96 & 222 & 256 & 62 \\
\hline 160 & 171 & 120 & 246 & 93 \\
\hline
\end{tabular}




\section{$\underline{\text { Remediation-Prioritization Index }}$}

A primary goal of the Stonycreek River Basin project was to prioritize individual mine discharges by a method that would show their relative severity with respect to all sampled discharges throughout the basin. If applicable, this method also could be used in other subbasins that are severely affected by mine drainage. A priority numbering system, or prioritization index (PI), was developed to identify the mine discharges that have the greatest effect on the receiving streams and that should be given a high priority for remediation. The remediation work would be designed to improve water quality in tributary streams and in the Stonycreek River. The PI was based on a site-to-site comparison of discharges of selected waterquality constituents. Discharges of the specific constituents were determined by multiplying the concentration in milligrams per liter or micrograms per liter times the flow rate in gallons per minute times a constant of 0.012 (for milligrams per liter) or 0.000012 (for micrograms per liter). The constant was used to convert concentration (in milligrams per liter or micrograms per liter) per flow rate (in gallons per minute) to pounds per day. Most mine discharge samples were collected during base-flow conditions. Because of funding limitations, sampling all 270 mine discharges at different flow conditions was not feasible. However, approximately 48 of the mine discharges were resampled 1 to 5 times and the data in appendix 3 show that the flow rate and constituent concentrations varied at the resampled sites. Data from the first sample collected at each mine discharge site were used for the PI calculations. When water-resource managers consider remediation at specific sites on the basis of these first-sample comparisons, they can take into consideration all data collected at each site and may want to consider collecting additional data at different flows and in different seasons to design treatment systems properly. The water-quality constituents used to calculate the PI included total iron, total manganese, dissolved aluminum, acidity, and total sulfate. The $\mathrm{pH}$ was indirectly used in the PI as a tie breaker for constituent discharges that were identical. These factors are related either directly or indirectly to the effects of coal-mine drainage on water quality. Low $\mathrm{pH}$ and high acidities are common to the most severe mine discharges. Total iron, total manganese, and $\mathrm{pH}$ in coal-mine drainage are limited by Federal regulations. The sulfate discharge is a reliable indicator of mine drainage because the neutralization processes that can occur in a mine discharge or stream do not greatly affect sulfate concentrations. Dissolved aluminum in waters having low $\mathrm{pH}$ affects fish and some other forms of aquatic life (Driscoll and others, 1980). Flow of a mine discharge is very significant because the flow and the concentration of a constituent determine the constituent discharge.

A computerized spreadsheet of the water-quality data at all sites was used to simplify the PI calculations. The spreadsheet was used to complete a primary sort on the discharges of each constituent in order of ascending or improving water quality. Table 5 shows how total-iron discharges were sorted, ranked, and scored for the PI calculations. The left four columns of table 5 show the unsorted total-iron data for sites 1 through 56 . The right six columns of table 5 show how the 56 sites of all 270 sites with the highest total-iron discharges were sorted, ranked, and scored. The text below refers to the sorted total-iron data in table 5. A rank number was assigned to each total-iron discharge in a descending order, with a rank 1 for the largest total-iron discharge $(1,700 \mathrm{lb} / \mathrm{d})$, and a rank 56 for the smallest total-iron discharge $(10.2 \mathrm{lb} / \mathrm{d})$. Each discharge was then given a score based on the rank. A score of 1 to 10 was assigned to each discharge by subdividing the 270 sites into 10 percent groups. The first 10 percent group (rank 1-27) received a score of 10 . The next 10 percent group (rank 28-54) received a score of 9 , and so on. If sites had identical discharges, a secondary sort was conducted on the discharges to break the tie, using $\mathrm{pH}$ as the tie breaker. The discharge with the lower $\mathrm{pH}$ received the lower rank number. Sites 165 and 15 both had total-iron discharges of $69.1 \mathrm{lb} / \mathrm{d}$. The $\mathrm{pH}$ at site 165 was 2.7 and the $\mathrm{pH}$ at site 15 was 3.6, so site 165 received the lower rank number. Discharges for all five water-quality constituents were sorted, ranked, and scored by this method. The final score for each site was then calculated by adding the scores for the five water-quality constituents. The final rank or PI was determined by assigning the largest final score the number 1 , the second largest score the number 2, and so forth through all 270 sites. Flow was used as a tie breaker for identical final scores. The site with the largest flow received the lower rank number. The final rank or PI shows which mine discharges have the greatest potential effect on the water quality of the receiving streams, in a descending order. The complete spreadsheet showing the individual ranks and scores for each water-quality constituent at all sampled discharges and the final PI for each mine discharge is given in appendix 4 . 
Table 5. Unsorted total-iron data and sorted, ranked, and scored total-iron data used for the Prioritization Index (PI) calculations

[gal/min, gallons per minute; $\mu \mathrm{g} / \mathrm{L}$, micrograms per liter; lb/d, pounds per day]

\begin{tabular}{|c|c|c|c|c|c|c|c|c|c|}
\hline \multicolumn{4}{|c|}{ Unsorted total-iron data } & \multicolumn{6}{|c|}{ Sorted, ranked, and scored total-iron data } \\
\hline $\begin{array}{c}\text { Site } \\
\text { number }\end{array}$ & $\begin{array}{c}\text { Flow } \\
\text { (gal/min) }\end{array}$ & $\begin{array}{c}\text { Total-iron } \\
\text { concentration } \\
(\mu \mathrm{g} / \mathrm{L})\end{array}$ & $\begin{array}{c}\text { Total-iron } \\
\text { discharge } \\
\text { (lb/d) }\end{array}$ & $\begin{array}{c}\text { Site } \\
\text { number }\end{array}$ & $\begin{array}{c}\text { Flow } \\
\text { (gal/min) }\end{array}$ & $\begin{array}{c}\text { Total-iron } \\
\text { concentration } \\
(\mu \mathrm{g} / \mathrm{L})\end{array}$ & $\begin{array}{c}\text { Total-iron } \\
\text { discharge } \\
(\mathrm{lb} / \mathrm{d})\end{array}$ & Rank & Score \\
\hline 1 & 16 & 46,000 & 8.83 & 16 & 2250 & 63,000 & 1,700 & 1 & 10 \\
\hline 2 & 9.0 & 3,800 & .410 & 149 & 310 & 300,000 & 1,120 & 2 & 10 \\
\hline 3 & 155 & 75,000 & 140 & 19 & 1780 & 41,000 & 876 & 3 & 10 \\
\hline 4 & 348 & 30,000 & 125 & 242 & 22 & $2,750,000$ & 726 & 4 & 10 \\
\hline 5 & 341 & 40 & .164 & 176 & 330 & 110,000 & 436 & 5 & 10 \\
\hline 6 & 306 & 9,900 & 36.4 & 125 & 225 & 130,000 & 351 & 6 & 10 \\
\hline 7 & 91 & 11,000 & 12.0 & 178 & 1620 & 17,000 & 330 & 7 & 10 \\
\hline 8 & 5.8 & 62,000 & 4.32 & 173 & 470 & 34,000 & 192 & 8 & 10 \\
\hline 9 & 6.7 & 38,000 & 3.06 & 110 & 449 & 30,000 & 162 & 9 & 10 \\
\hline 10 & 122 & 750 & 1.10 & 3 & 155 & 75,000 & 140 & 10 & 10 \\
\hline 11 & 136 & 5,800 & 9.47 & 4 & 348 & 30,000 & 125 & 11 & 10 \\
\hline 12 & 86 & 13,000 & 13.42 & 141 & 48 & 210,000 & 121 & 12 & 10 \\
\hline 13 & 52 & 8,300 & 5.18 & 81 & 1400 & 6,900 & 116 & 13 & 10 \\
\hline 14 & 799 & 880 & 8.44 & 225 & 60 & 120,000 & 86.4 & 14 & 10 \\
\hline 15 & 96 & 60,000 & 69.1 & 109 & 180 & 39,000 & 84.2 & 15 & 10 \\
\hline 16 & 2,250 & 63,000 & 1,700 & 22 & 224 & 30,000 & 80.6 & 16 & 10 \\
\hline 17 & 284 & 3,400 & 11.6 & 165 & 18 & 320,000 & 69.1 & 17 & 10 \\
\hline 18 & 11 & 6,600 & .871 & 15 & 96 & 60,000 & 69.1 & 18 & 10 \\
\hline 19 & 1,780 & 41,000 & 876 & 97 & 197 & 28,000 & 66.2 & 19 & 10 \\
\hline 20 & .7 & $4,760,000$ & 40.0 & 184 & 45 & 120,000 & 64.8 & 20 & 10 \\
\hline 21 & 46 & 6,900 & 3.81 & 38 & 78 & 66,000 & 61.8 & 21 & 10 \\
\hline 22 & 224 & 30,000 & 80.6 & 180 & 25 & 180,000 & 54.0 & 22 & 10 \\
\hline 23 & 12 & 300 & .043 & 205 & 75 & 52,000 & 46.8 & 23 & 10 \\
\hline 24 & 3.0 & 210,000 & 7.56 & 95 & 981 & 3,500 & 41.2 & 24 & 10 \\
\hline 25 & 3.9 & 68,000 & 3.18 & 248 & 114 & 30,000 & 41.0 & 25 & 10 \\
\hline 26 & 1.5 & 23,000 & .414 & 20 & .7 & $4,760,000$ & 40.0 & 26 & 10 \\
\hline 27 & 1.0 & 30,000 & .360 & 55 & 45 & 72,000 & 38.9 & 27 & 10 \\
\hline 28 & 84 & 1,200 & 1.21 & 6 & 306 & 9,900 & 36.4 & 28 & 9 \\
\hline 29 & 19 & 30 & .007 & 219 & 18 & 160,000 & 34.6 & 29 & 9 \\
\hline 30 & 4.4 & 2,100 & .111 & 204 & 60 & 48,000 & 34.6 & 30 & 9 \\
\hline 31 & 155 & 2,000 & 3.72 & 79 & 2 & $1,300,000$ & 31.2 & 31 & 9 \\
\hline 32 & 18 & 1,100 & .238 & 164 & 97 & 26,000 & 30.3 & 32 & 9 \\
\hline 33 & 8.4 & 330 & .033 & 144 & 185 & 13,000 & 28.9 & 33 & 9 \\
\hline 34 & 42 & 32,000 & 16.1 & 166 & 13 & 150,000 & 23.4 & 34 & 9 \\
\hline 35 & 48 & 5,200 & 3.00 & 140 & 27 & 70,000 & 22.7 & 35 & 9 \\
\hline 36 & 43 & 13,000 & 6.71 & 58 & 35 & 47,000 & 19.7 & 36 & 9 \\
\hline 37 & 6.8 & 1,100 & .090 & 188 & 51 & 31,000 & 19.0 & 37 & 9 \\
\hline 38 & 78 & 66,000 & 61.8 & 249 & 41 & 36,000 & 17.7 & 38 & 9 \\
\hline 39 & 63 & 820 & .620 & 208 & 374 & 3,700 & 16.6 & 39 & 9 \\
\hline 40 & 75 & 4,800 & 4.32 & 170 & 142 & 9,700 & 16.5 & 40 & 9 \\
\hline 41 & 9.0 & 78,000 & 8.42 & 104 & 200 & 6,800 & 16.3 & 41 & 9 \\
\hline 42 & 36 & 5,400 & 2.33 & 174 & 7.5 & 180,000 & 16.2 & 42 & 9 \\
\hline 43 & .5 & 27,000 & .162 & 34 & 42 & 32,000 & 16.1 & 43 & 9 \\
\hline 44 & 133 & 140 & .223 & 121 & 1510 & 760 & 13.8 & 44 & 9 \\
\hline 45 & .04 & 290 & .000 & 63 & 277 & 4,100 & 13.6 & 45 & 9 \\
\hline 46 & 20 & 7,500 & 1.80 & 12 & 86 & 13,000 & 13.4 & 46 & 9 \\
\hline 47 & 1.6 & 38,000 & 0.730 & 169 & 15 & 74,000 & 13.32 & 47 & 9 \\
\hline
\end{tabular}


Table 5. Unsorted total-iron data and sorted, ranked, and scored total-iron data used for the Prioritization Index (PI) calculations-Continued

[gal/min, gallons per minute; $\mu \mathrm{g} / \mathrm{L}$, micrograms per liter; lb/d, pounds per day]

\begin{tabular}{|c|c|c|c|c|c|c|c|c|c|}
\hline \multicolumn{4}{|c|}{ Unsorted total-iron data } & \multicolumn{6}{|c|}{ Sorted, ranked, and scored total-iron data } \\
\hline $\begin{array}{c}\text { Site } \\
\text { number }\end{array}$ & $\begin{array}{c}\text { Flow } \\
\text { (gal/min) }\end{array}$ & $\begin{array}{c}\text { Total-iron } \\
\text { concentration } \\
(\mu \mathrm{g} / \mathrm{L})\end{array}$ & $\begin{array}{c}\text { Total-iron } \\
\text { discharge } \\
(\mathrm{lb} / \mathrm{d})\end{array}$ & $\begin{array}{c}\text { Site } \\
\text { number }\end{array}$ & $\begin{array}{c}\text { Flow } \\
\text { (gal/min) }\end{array}$ & $\begin{array}{c}\text { Total-iron } \\
\text { concentration } \\
(\mu \mathrm{g} / \mathrm{L})\end{array}$ & $\begin{array}{c}\text { Total-iron } \\
\text { discharge } \\
(\mathrm{lb} / \mathrm{d})\end{array}$ & Rank & Score \\
\hline 48 & 8.0 & 6,400 & .614 & 190 & 60 & 18,000 & 12.96 & 48 & 9 \\
\hline 49 & 3.4 & 4,800 & .196 & 160 & 171 & 5,900 & 12.11 & 49 & 9 \\
\hline 50 & 1.0 & 330 & .004 & 7 & 91 & 11,000 & 12.01 & 50 & 9 \\
\hline 51 & 18 & 300 & .065 & 17 & 284 & 3,400 & 11.59 & 51 & 9 \\
\hline 52 & .2 & 9,500 & .023 & 187 & 36 & 26,000 & 11.23 & 52 & 9 \\
\hline 53 & 4.6 & 1,200 & .066 & 207 & 221 & 4,200 & 11.14 & 53 & 9 \\
\hline 54 & 111 & 7,900 & 10.523 & 191 & 5 & 180,000 & 10.80 & 54 & 9 \\
\hline 55 & 45 & 72,000 & 38.880 & 54 & 111 & 7,900 & 10.52 & 55 & 8 \\
\hline 56 & 20 & 240 & .058 & 124 & 18 & 47,000 & 10.15 & 56 & 8 \\
\hline
\end{tabular}

A PI also was established for all mine discharges in certain subbasins that were moderately to severely effected by mine drainage. This was done so that water-resource managers could work on a subbasin approach in designing remediation plans. The subbasins prioritized included Shade Creek, Paint Creek, Wells Creek, Quemahoning Creek, Oven Run, and Pokeytown Run. The subbasin data are listed in tables 6-11. Locations of the subbasin sites are shown in figures 6-11

The GIS data base containing the site locations and PI provides an effective means for viewing the spatial distribution and magnitude of each sampled mine discharge throughout the basin. The GIS was also useful in viewing spatial relations of mine discharges with high quality streams, population centers, existing wetlands, land use, and land slope. 
Table 6. Prioritization index (PI) for coal-mine discharges in the Shade Creek Basin

[gal/min, gallon per minute; lb/d, pound per day; <, less than]

\begin{tabular}{|c|c|c|c|c|c|c|c|c|c|}
\hline $\begin{array}{c}\text { Site } \\
\text { number }\end{array}$ & $\begin{array}{c}\mathrm{pH} \\
\text { (units) }\end{array}$ & $\begin{array}{l}\text { Iron, } \\
\text { total } \\
(\mathrm{lb} / \mathrm{d} \\
\text { as Fe) }\end{array}$ & $\begin{array}{c}\text { Acidity, } \\
\text { total heated } \\
(\mathrm{lb} / \mathrm{d} \text { as } \\
\left.\mathrm{CaCO}_{3}\right)\end{array}$ & $\begin{array}{c}\text { Sulfate, } \\
\text { total } \\
(\mathrm{lb} / \mathrm{d} \text { as } \\
\left.\mathrm{SO}_{4}\right) \\
\end{array}$ & $\begin{array}{c}\text { Aluminum, } \\
\text { dissolved } \\
\text { (lb/d } \\
\text { as Al) } \\
\end{array}$ & $\begin{array}{c}\text { Manganese, } \\
\text { total } \\
\text { (lb/d } \\
\text { as } \mathrm{Mn} \\
\end{array}$ & $\begin{array}{c}\text { Discharge, } \\
\text { instantaneous } \\
\text { (gal/min) }\end{array}$ & $\begin{array}{l}\text { Final } \\
\text { score }\end{array}$ & $\mathrm{PI}$ \\
\hline 16 & 3.3 & 1,700 & 6,750 & 29,700 & 486 & 232 & 2250 & 50 & 1 \\
\hline 19 & 5.1 & 876 & 1580 & 10,300 & 25.6 & 85.4 & 1780 & 50 & 2 \\
\hline 15 & 3.6 & 69.1 & 256 & 1,130 & 18.4 & 19.6 & 96 & 50 & 3 \\
\hline 14 & 3.6 & 8.44 & 844 & 7,000 & 93.0 & 64.2 & 799 & 49 & 4 \\
\hline 38 & 3.0 & 61.8 & 414 & 796 & 38.4 & 6.08 & 78 & 49 & 5 \\
\hline 42 & 3.1 & 2.33 & 86.4 & 562 & 6.05 & 11.2 & 36 & 45 & 6 \\
\hline 40 & 3.1 & 4.32 & 148 & 378 & 12.6 & 4.86 & 75 & 44 & 7 \\
\hline 76 & 3.4 & 7.14 & 52.9 & 239 & 4.12 & 1.34 & 35 & 44 & 8 \\
\hline 221 & 3.2 & 2.09 & 47.5 & 612 & 3.31 & 1.73 & 60 & 43 & 9 \\
\hline 231 & 3.4 & .92 & 62.2 & 478 & 3.28 & 5.76 & 48 & 43 & 10 \\
\hline 20 & 2.4 & 39.9 & 165 & 227 & 1.34 & .50 & .7 & 42 & 11 \\
\hline 75 & 3.3 & 1.98 & 28.8 & 176 & 1.22 & 1.22 & 30 & 40 & 12 \\
\hline 234 & 3.5 & 3.22 & 13.8 & 104 & .10 & 1.14 & 7.9 & 38 & 13 \\
\hline 236 & 5.4 & .02 & 25.9 & 421 & .39 & .39 & 45 & 34 & 14 \\
\hline 41 & 5.5 & 8.42 & 13.0 & 52.9 & .01 & .44 & 9 & 34 & 15 \\
\hline 215 & 3.0 & .35 & 9.46 & 53.4 & .38 & .58 & 7.3 & 34 & 16 \\
\hline 214 & 3.1 & .13 & 8.35 & 63.4 & .85 & .29 & 12 & 33 & 17 \\
\hline 232 & 2.7 & 1.08 & 6.58 & 29.6 & .02 & .36 & 1.3 & 32 & 18 \\
\hline 247 & 6.6 & .39 & $<.01$ & 675 & .10 & .68 & 67 & 31 & 19 \\
\hline 235 & 3.7 & .06 & 5.69 & 6.7 & .18 & .71 & 7.9 & 31 & 20 \\
\hline 216 & 5.5 & 6.27 & 9.65 & 39.4 & .01 & .33 & 6.7 & 31 & 21 \\
\hline 39 & 6.2 & .62 & $<.01$ & 159 & .08 & .46 & 63 & 30 & 22 \\
\hline 233 & 2.7 & .49 & 4.03 & 20.4 & .05 & .28 & 1 & 29 & 23 \\
\hline 37 & 3.6 & .09 & 2.94 & 21.2 & .19 & .25 & 6.8 & 28 & 24 \\
\hline 27 & 3.0 & .36 & 5.04 & 10.6 & .50 & .14 & 1 & 28 & 25 \\
\hline 229 & 6.2 & .63 & $<.01$ & 97.9 & .04 & .11 & 24 & 27 & 26 \\
\hline 230 & 6.1 & .35 & $<.01$ & 25.1 & .01 & .17 & 7.2 & 23 & 27 \\
\hline 238 & 5.3 & .01 & 4.03 & 119 & .04 & .01 & 14 & 22 & 28 \\
\hline 43 & 3.5 & .16 & .83 & 2.16 & .05 & .06 & .5 & 22 & 29 \\
\hline 245 & 6.0 & .03 & $<.01$ & 67.7 & .02 & .02 & 12 & 21 & 30 \\
\hline 200 & 4.6 & .02 & 2.16 & 12.6 & .05 & .05 & 7.5 & 21 & 31 \\
\hline 265 & 6.3 & 1.04 & .46 & 6.91 & $<.01$ & .08 & 1.2 & 21 & 32 \\
\hline 86 & 6.6 & .07 & $<.01$ & 15.1 & .01 & .05 & 9 & 17 & 33 \\
\hline 243 & 6.3 & .19 & $<.01$ & 12.3 & .01 & $<.01$ & 7.9 & 17 & 34 \\
\hline 85 & 4.6 & .06 & .33 & 8.40 & $<.01$ & .08 & 2.5 & 17 & 35 \\
\hline 246 & 6.4 & $<.01$ & $<.01$ & 32.3 & $<.01$ & .01 & 3.9 & 14 & 36 \\
\hline 201 & 4.2 & $<.01$ & .50 & 2.11 & .01 & .01 & 1.6 & 14 & 37 \\
\hline 237 & 3.6 & .12 & .20 & 1.73 & $<.01$ & $<.01$ & .2 & 13 & 38 \\
\hline 244 & 6.3 & .01 & $<.01$ & 6.34 & $<.01$ & $<.01$ & 4.8 & 11 & 39 \\
\hline 266 & 6.8 & .06 & $<.01$ & 4.61 & $<.01$ & $<.01$ & .8 & 10 & 40 \\
\hline 267 & 6.6 & .07 & $<.01$ & .02 & $<.01$ & .01 & .4 & 10 & 41 \\
\hline 239 & 6.0 & .05 & .02 & .11 & $<.01$ & $<.01$ & .1 & 10 & 42 \\
\hline 222 & 5.6 & $<.01$ & $<.01$ & 4.18 & $<.01$ & $<.01$ & 1.2 & 9 & 43 \\
\hline 240 & 5.8 & .01 & .03 & .98 & $<.01$ & $<.01$ & .2 & 9 & 44 \\
\hline
\end{tabular}


Table 7. Prioritization index (PI) for coal-mine discharges in the Paint Creek Basin

[gal/min, gallon per minute; lb/d, pounds per day; <, less than]

\begin{tabular}{|c|c|c|c|c|c|c|c|c|c|}
\hline $\begin{array}{c}\text { Site } \\
\text { number }\end{array}$ & $\begin{array}{c}\mathrm{pH} \\
\text { (units) }\end{array}$ & $\begin{array}{l}\text { Iron, } \\
\text { total } \\
(\mathrm{lb} / \mathrm{d} \\
\text { as Fe) }\end{array}$ & $\begin{array}{c}\text { Acidity, } \\
\text { total heated } \\
\text { (lb/d as } \\
\left.\mathrm{CaCO}_{3}\right)\end{array}$ & $\begin{array}{l}\text { Sulfate, } \\
\text { total } \\
(\mathrm{lb} / \mathrm{d} \text { as } \\
\left.\mathrm{SO}_{4}\right)\end{array}$ & $\begin{array}{l}\text { Aluminum, } \\
\text { dissolved } \\
\text { (lb/d } \\
\text { as Al) }\end{array}$ & $\begin{array}{c}\text { Manganese, } \\
\text { total } \\
(\mathrm{lb} / \mathrm{d} \\
\text { as } \mathrm{Mn}\end{array}$ & $\begin{array}{c}\text { Discharge, } \\
\text { instantaneous } \\
\text { (gal/min) }\end{array}$ & $\begin{array}{l}\text { Final } \\
\text { score }\end{array}$ & $\mathrm{PI}$ \\
\hline 81 & 4.8 & 116 & 739 & 12,100 & 31.9 & 47.0 & 1400 & 50 & 1 \\
\hline 125 & 2.4 & 351 & 3,180 & 8,640 & 232 & 178 & 225 & 50 & 2 \\
\hline 141 & 2.7 & 121 & 751 & 864 & 42.6 & 63.4 & 48 & 49 & 3 \\
\hline 188 & 2.6 & 19.0 & 502 & 1,470 & 61.2 & 25.7 & 51 & 48 & 4 \\
\hline 103 & 3.2 & 7.85 & 481 & 5,760 & 34.0 & 25.6 & 436 & 47 & 5 \\
\hline 104 & 3.0 & 16.3 & 466 & 3,840 & 31.2 & 33.6 & 200 & 47 & 6 \\
\hline 184 & 2.8 & 64.8 & 242 & 1,240 & 13.0 & 2.27 & 45 & 43 & 7 \\
\hline 140 & 2.5 & 22.7 & 222 & 648 & 10.4 & 15.6 & 27 & 43 & 8 \\
\hline 117 & 3.1 & 8.32 & 235 & 605 & 27.7 & 17.1 & 21 & 43 & 9 \\
\hline 124 & 2.6 & 10.2 & 187 & 648 & 19.2 & 11.4 & 18 & 42 & 10 \\
\hline 31 & 3.2 & 3.72 & 182 & 670 & 16.9 & 10.6 & 155 & 41 & 11 \\
\hline 219 & 2.4 & 34.6 & 203 & 518 & 2.59 & 6.70 & 18 & 40 & 12 \\
\hline 101 & 3.2 & 2.39 & 132 & 1100 & 6.60 & 2.53 & 117 & 38 & 13 \\
\hline 187 & 2.4 & 11.2 & 164 & 562 & 9.50 & 1.34 & 36 & 38 & 14 \\
\hline 44 & 3.6 & .22 & 99.0 & 1150 & 8.62 & 3.99 & 133 & 37 & 15 \\
\hline 28 & 3.1 & 1.21 & 101 & 433 & 9.98 & 5.85 & 84 & 37 & 16 \\
\hline 139 & 2.6 & 9.20 & 73.0 & 250 & 3.12 & 6.08 & 13 & 36 & 17 \\
\hline 126 & 2.9 & 1.22 & 86.1 & 253 & 8.74 & 7.49 & 26 & 35 & 18 \\
\hline 46 & 3.2 & 1.80 & 50.4 & 118 & 5.28 & 1.18 & 20 & 32 & 19 \\
\hline 142 & 2.2 & 4.20 & 33.6 & 102 & 1.47 & 2.79 & 2.5 & 31 & 20 \\
\hline 100 & 5.8 & .21 & 5.07 & 1770 & 1.86 & 2.91 & 352 & 30 & 21 \\
\hline 111 & 3.4 & .19 & 29.5 & 216 & 3.06 & 2.34 & 30 & 30 & 22 \\
\hline 79 & 2.2 & 31.2 & 94.6 & 149 & 2.38 & .24 & 2 & 29 & 23 \\
\hline 32 & 3.4 & .24 & 13.8 & 207 & 1.32 & .93 & 18 & 27 & 24 \\
\hline 77 & 3.8 & .10 & 24.3 & 100 & 3.10 & 2.69 & 3.8 & 27 & 25 \\
\hline 78 & 4.5 & .02 & 21.8 & 679 & .63 & .94 & 65 & 25 & 26 \\
\hline 116 & 3.6 & .16 & 13.7 & 178 & 1.15 & 1.19 & 15 & 25 & 27 \\
\hline 112 & 3.5 & .06 & 10.7 & 132 & 1.15 & .75 & 12 & 23 & 28 \\
\hline 185 & 2.7 & 1.39 & 13.2 & 54.7 & .62 & .09 & 1.9 & 21 & 29 \\
\hline 29 & 4.1 & $<.01$ & 11.9 & 141 & 1.62 & .32 & 19 & 20 & 30 \\
\hline 113 & 3.3 & .04 & 8.72 & 94.8 & .91 & .58 & 7.9 & 20 & 31 \\
\hline 96 & 6.3 & .38 & $<.01$ & 437 & .08 & .29 & 52 & 19 & 32 \\
\hline 217 & 2.9 & 1.32 & 10.7 & 29.7 & .54 & .09 & 2.5 & 19 & 33 \\
\hline 268 & 6.3 & .34 & $<.01$ & 326 & .14 & .33 & 40 & 18 & 34 \\
\hline 127 & 2.6 & 1.72 & 7.58 & 25.0 & .02 & .50 & 1.3 & 18 & 35 \\
\hline 33 & 3.9 & .03 & 4.44 & 86.7 & .50 & .57 & 8.4 & 17 & 36 \\
\hline 114 & 3.5 & .04 & 5.94 & 79.2 & .58 & .48 & 5.5 & 17 & 37 \\
\hline 30 & 3.1 & .11 & 7.39 & 24.8 & .74 & .40 & 4.4 & 17 & 38 \\
\hline 220 & 3.5 & .03 & 5.57 & 54.7 & .47 & .59 & 8.6 & 16 & 39 \\
\hline 115 & 3.6 & .05 & 4.31 & 56.2 & .37 & .51 & 3.9 & 16 & 40 \\
\hline 138 & 2.7 & .33 & 4.11 & 16.7 & .21 & .44 & 1.6 & 15 & 41 \\
\hline 218 & 5.6 & .27 & $<.01$ & 265 & .06 & .01 & 33 & 14 & 42 \\
\hline 80 & 2.7 & .62 & 3.36 & 6.24 & .12 & .03 & .4 & 12 & 43 \\
\hline 118 & 2.6 & .22 & 2.64 & 6.84 & .23 & .12 & .3 & 12 & 44 \\
\hline 102 & 4.7 & .01 & 2.16 & 14.6 & .06 & .08 & 15 & 6 & 45 \\
\hline 45 & 9.7 & $<.01$ & $<.01$ & .41 & $<.01$ & $<.01$ & .04 & 5 & 46 \\
\hline
\end{tabular}


Table 8. Prioritization index (Pl) for coal-mine discharges in the Wells Creek Basin

[gal/min, gallon per minute; lb/d, pounds per day; <, less than]

\begin{tabular}{|c|c|c|c|c|c|c|c|c|c|}
\hline $\begin{array}{c}\text { Site } \\
\text { number }\end{array}$ & $\begin{array}{c}\mathrm{pH} \\
\text { (units) }\end{array}$ & $\begin{array}{l}\text { Iron, } \\
\text { total } \\
(\mathrm{lb} / \mathrm{d} \\
\text { as Fe) }\end{array}$ & $\begin{array}{c}\text { Acidity, } \\
\text { total heated } \\
(\mathrm{lb} / \mathrm{d} \text { as } \\
\left.\mathrm{CaCO}_{3}\right)\end{array}$ & $\begin{array}{c}\text { Sulfate, } \\
\text { total } \\
(\mathrm{lb} / \mathrm{d} \text { as } \\
\left.\mathrm{SO}_{4}\right)\end{array}$ & $\begin{array}{c}\text { Aluminum, } \\
\text { dissolved } \\
\text { (lb/d } \\
\text { as Al) }\end{array}$ & $\begin{array}{c}\text { Manganese, } \\
\text { total } \\
(\mathrm{lb} / \mathrm{d} \\
\text { as } \mathrm{Mn}\end{array}$ & $\begin{array}{c}\text { Discharge, } \\
\text { instantaneous } \\
\text { (gal/min) }\end{array}$ & $\begin{array}{l}\text { Final } \\
\text { score }\end{array}$ & PI \\
\hline 22 & 3.0 & 80.6 & 538 & 2,020 & 25.5 & 20.2 & 224 & 49 & 1 \\
\hline 17 & 3.3 & 11.6 & 198 & 1,260 & 17.0 & 6.48 & 284 & 44 & 2 \\
\hline 10 & 3.5 & 1.10 & 35.1 & 571 & 2.78 & 133 & 122 & 38 & 3 \\
\hline 11 & 4.4 & 9.47 & 32.6 & 588 & 1.31 & 2.61 & 136 & 35 & 4 \\
\hline 210 & 5.8 & 9.43 & $<.01$ & 524 & .35 & 5.35 & 97 & 29 & 5 \\
\hline 23 & 3.4 & .04 & 14.4 & 51.8 & 1.58 & 1.30 & 12 & 24 & 6 \\
\hline 223 & 5.6 & .75 & 1.74 & 78.0 & .06 & .90 & 25 & 21 & 7 \\
\hline 9 & 6.1 & 3.06 & $<.01$ & 30.6 & .01 & .21 & 6.7 & 17 & 8 \\
\hline 18 & 6.4 & .87 & $<.01$ & 31.7 & .01 & .11 & 11 & 13 & 9 \\
\hline
\end{tabular}

Table 9. Prioritization index (PI) for coal-mine discharges in the Quemahoning Creek Basin [gal/min, gallon per minute; lb/d, pounds per day; <, less than]

\begin{tabular}{|c|c|c|c|c|c|c|c|c|c|}
\hline $\begin{array}{c}\text { Site } \\
\text { number }\end{array}$ & $\begin{array}{c}\mathrm{pH} \\
\text { (units) }\end{array}$ & $\begin{array}{l}\text { Iron, } \\
\text { total } \\
(\mathrm{lb} / \mathrm{d} \\
\text { as Fe) }\end{array}$ & $\begin{array}{c}\text { Acidity, } \\
\text { total heated } \\
(\mathrm{lb} / \mathrm{d} \text { as } \\
\left.\mathrm{CaCO}_{3}\right)\end{array}$ & $\begin{array}{c}\text { Sulfate, } \\
\text { total } \\
(\mathrm{lb} / \mathrm{d} \text { as } \\
\left.\mathrm{SO}_{4}\right)\end{array}$ & $\begin{array}{c}\text { Aluminum, } \\
\text { dissolved } \\
\text { (lb/d } \\
\text { as Al) }\end{array}$ & $\begin{array}{c}\text { Manganese, } \\
\text { total } \\
\text { (lb/d } \\
\text { as } \mathrm{Mn}\end{array}$ & $\begin{array}{c}\text { Discharge, } \\
\text { instantaneous } \\
\text { (gal } / \mathrm{min})\end{array}$ & $\begin{array}{l}\text { Final } \\
\text { score }\end{array}$ & $\mathrm{PI}$ \\
\hline 208 & 6.2 & 16.6 & 3,050 & 5,830 & 539 & 58.3 & 374 & 49 & 1 \\
\hline 176 & 5.9 & 436 & 642 & 1,780 & .40 & 24.2 & 330 & 46 & 2 \\
\hline 172 & 2.8 & 2.38 & 93.6 & 342 & 8.64 & 5.04 & 30 & 43 & 3 \\
\hline 173 & 6.2 & 192 & $<.01$ & 4,570 & 1.13 & 24.8 & 470 & 41 & 4 \\
\hline 259 & 6.3 & 1.87 & $<.01$ & 4,580 & 1.35 & 1.98 & 867 & 35 & 5 \\
\hline 174 & 5.0 & 16.2 & 30.6 & 83.7 & .07 & 1.17 & 7.5 & 35 & 6 \\
\hline 175 & 3.2 & 2.22 & 7.20 & 28.8 & .32 & .66 & 5 & 33 & 7 \\
\hline 209 & 3.5 & 6.68 & $<.01$ & 230 & .15 & .92 & 64 & 31 & 8 \\
\hline 48 & 4.5 & .61 & 4.80 & 53.8 & .27 & .87 & 8 & 31 & 9 \\
\hline 258 & 3.8 & 1.51 & 6.42 & 38.4 & .21 & .33 & 3.3 & 30 & 10 \\
\hline 54 & 6.7 & 10.5 & $<.01$ & 129 & .19 & .84 & 111 & 28 & 11 \\
\hline 53 & 3.6 & .07 & 3.97 & 28.2 & .43 & .04 & 4.6 & 25 & 12 \\
\hline 171 & 6.6 & .79 & $<.01$ & 124 & .11 & .42 & 69 & 23 & 13 \\
\hline 47 & 3.2 & .73 & 3.69 & 14.8 & .17 & .27 & 1.6 & 23 & 14 \\
\hline 183 & 4.2 & .05 & 1.44 & 7.56 & .14 & .10 & 3 & 20 & 15 \\
\hline 92 & 5.8 & .02 & .24 & 22.4 & $<.01$ & .02 & 1.7 & 16 & 16 \\
\hline 182 & 5.2 & .18 & .20 & 1.44 & $<.01$ & .03 & 1 & 15 & 17 \\
\hline 52 & 3.8 & .02 & .12 & 1.32 & $<.01$ & $<.01$ & .2 & 11 & 18 \\
\hline 256 & 5.8 & $<.01$ & .05 & .30 & $<.01$ & $<.01$ & .8 & 8 & 19 \\
\hline 257 & 6.9 & $<.01$ & $<.01$ & 4.09 & $<.01$ & $<.01$ & 1.1 & 7 & 20 \\
\hline
\end{tabular}


Table 10. Prioritization index (PI) for coal-mine discharges in the Oven Run Basin [gal/min, gallon per minute; lb/d, pounds per day]

\begin{tabular}{|c|c|c|c|c|c|c|c|c|c|}
\hline $\begin{array}{c}\text { Site } \\
\text { number }\end{array}$ & $\begin{array}{c}\mathrm{pH} \\
\text { (units) }\end{array}$ & $\begin{array}{l}\text { Iron, } \\
\text { total } \\
(\mathrm{lb} / \mathrm{d} \\
\text { as } \mathrm{Fe})\end{array}$ & $\begin{array}{c}\text { Acidity, } \\
\text { total heated } \\
\text { (lb/d as } \\
\mathrm{CaCO} 3)\end{array}$ & $\begin{array}{l}\text { Sulfate, } \\
\text { total } \\
(\mathrm{lb} / \mathrm{d} \\
\left.\text { as } \mathrm{SO}_{4}\right)\end{array}$ & $\begin{array}{c}\text { Aluminum, } \\
\text { dissolved } \\
\text { (lb/d } \\
\text { as Al) }\end{array}$ & $\begin{array}{c}\text { Manganese, } \\
\text { total } \\
(\mathrm{lb} / \mathrm{d} \\
\text { as } \mathrm{Mn})\end{array}$ & $\begin{array}{c}\text { Discharge, } \\
\text { instantaneous } \\
\text { (gal/min) }\end{array}$ & $\begin{array}{l}\text { Final } \\
\text { score }\end{array}$ & $\mathrm{PI}$ \\
\hline 3 & 2.8 & 140 & 1,170 & 2,980 & 100 & 42.8 & 155 & 50 & 1 \\
\hline 60 & 2.9 & .38 & 55.3 & 384 & 6.60 & 10.8 & 6.4 & 39 & 2 \\
\hline 227 & 3.0 & 1.89 & 84.6 & 144 & 9.90 & 1.71 & 7.5 & 35 & 3 \\
\hline 24 & 3.0 & 7.56 & 30.2 & 122 & 2.23 & 4.68 & 3.0 & 34 & 4 \\
\hline 72 & 3.7 & .08 & 45.4 & 144 & 5.78 & 4.54 & 8.6 & 30 & 5 \\
\hline 59 & 2.9 & 2.72 & 24.6 & 100 & 2.05 & 2.90 & 3.1 & 28 & 6 \\
\hline 71 & 3.8 & .10 & 24.3 & 100 & 3.10 & 2.69 & 3.8 & 22 & 7 \\
\hline 73 & 3.5 & 1.73 & 15.0 & 76.8 & 1.09 & 2.30 & 1.6 & 19 & 8 \\
\hline 158 & 3.8 & 1.20 & 5.10 & 21.6 & .44 & .72 & .5 & 12 & 9 \\
\hline 159 & 4.6 & .09 & 2.54 & 21.2 & .36 & .66 & 2.3 & 6 & 10 \\
\hline
\end{tabular}

Table 11. Prioritization index (PI) for coal-mine discharges in the Pokeytown Run Basin [gal/min, gallon per minute; lb/d, pounds per day; <, less than]

\begin{tabular}{|c|c|c|c|c|c|c|c|c|c|}
\hline $\begin{array}{c}\text { Site } \\
\text { number }\end{array}$ & $\begin{array}{c}\mathrm{pH} \\
\text { (units) }\end{array}$ & $\begin{array}{l}\text { Iron, } \\
\text { total } \\
(\mathrm{lb} / \mathrm{d} \\
\text { as Fe) }\end{array}$ & $\begin{array}{c}\text { Acidity, } \\
\text { total heated } \\
(\mathrm{lb} / \mathrm{d} \text { as } \\
\left.\mathrm{CaCO}_{3}\right)\end{array}$ & $\begin{array}{c}\text { Sulfate, } \\
\text { total } \\
(\mathrm{lb} / \mathrm{d} \text { as } \\
\left.\mathrm{SO}_{4}\right)\end{array}$ & $\begin{array}{l}\text { Aluminum, } \\
\text { dissolved } \\
\text { (lb/d } \\
\text { as Al) }\end{array}$ & $\begin{array}{c}\text { Manganese, } \\
\text { total } \\
(\mathrm{lb} / \mathrm{d} \\
\text { as } \mathrm{Mn}\end{array}$ & $\begin{array}{c}\text { Discharge, } \\
\text { instantaneous } \\
\text { (gal/min) }\end{array}$ & $\begin{array}{l}\text { Final } \\
\text { score }\end{array}$ & $\mathrm{PI}$ \\
\hline 242 & 2.3 & 726 & 3,230 & 5,280 & 259 & 7.39 & 22 & 49 & 1 \\
\hline 4 & 2.8 & 125 & 1,130 & 4,010 & 83.5 & 21.7 & 348 & 46 & 2 \\
\hline 34 & 2.7 & 16.1 & 156 & 605 & 10.6 & 7.06 & 42 & 40 & 3 \\
\hline 1 & 2.8 & 8.83 & 73.0 & 288 & 6.14 & 5.76 & 16 & 35 & 4 \\
\hline 94 & 3.0 & 3.90 & 21.4 & 51.0 & .75 & 4.50 & 2.5 & 28 & 5 \\
\hline 35 & 6.0 & 3.00 & $<.01$ & 173 & .12 & 1.84 & 48 & 24 & 6 \\
\hline 2 & 3.1 & .41 & 9.94 & 107 & .56 & .95 & 9 & 23 & 7 \\
\hline 87 & 6.4 & .24 & $<.01$ & 12.7 & $<.01$ & .09 & 1.8 & 15 & 8 \\
\hline
\end{tabular}




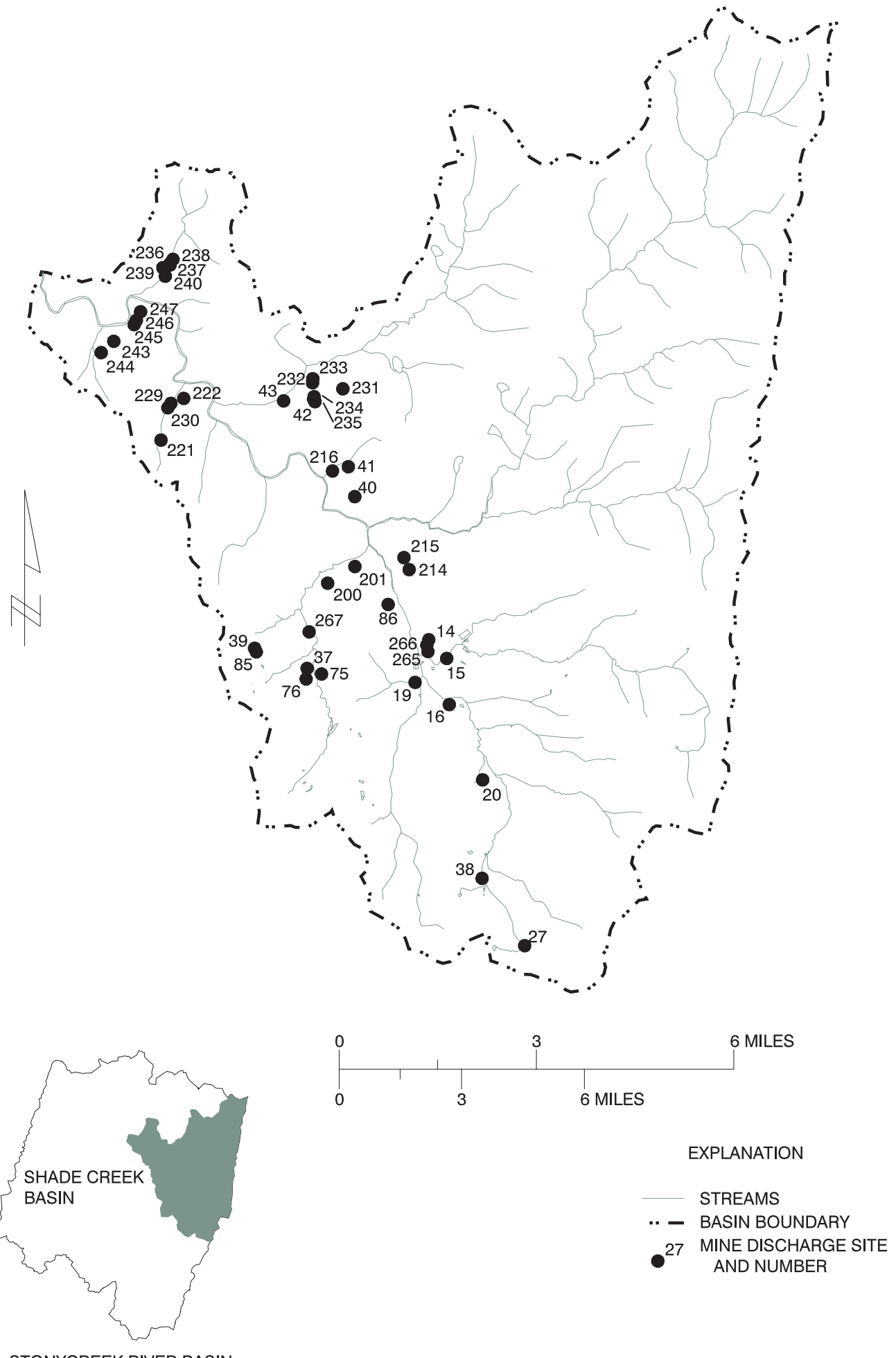

STONYCREEK RIVER BASIN

Figure 6. Location of the coal-mine-discharge sites in the Shade Creek Basin. 


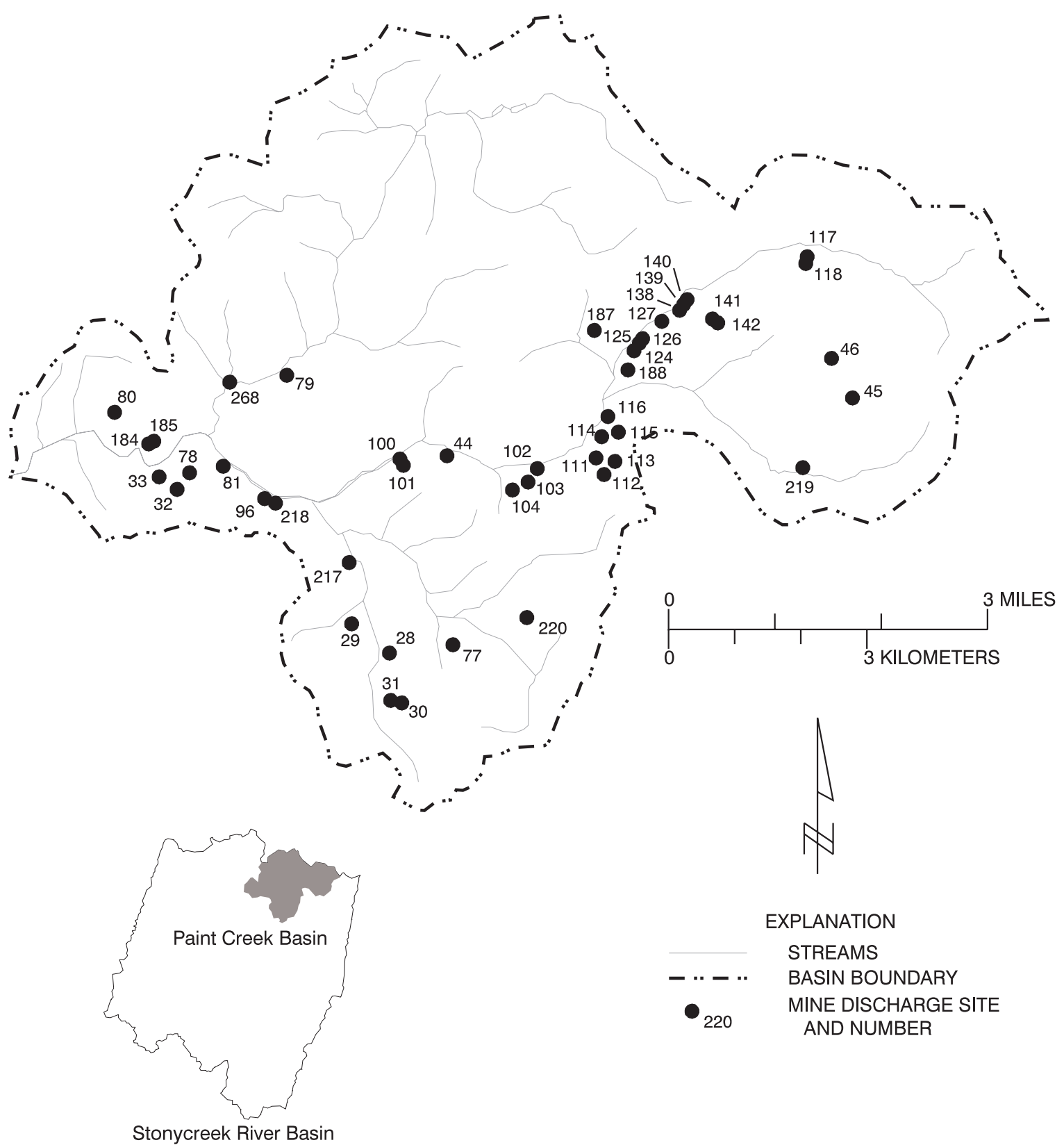

Figure 7. Location of the coal-mine-discharge sites in the Paint Creek Basin. 

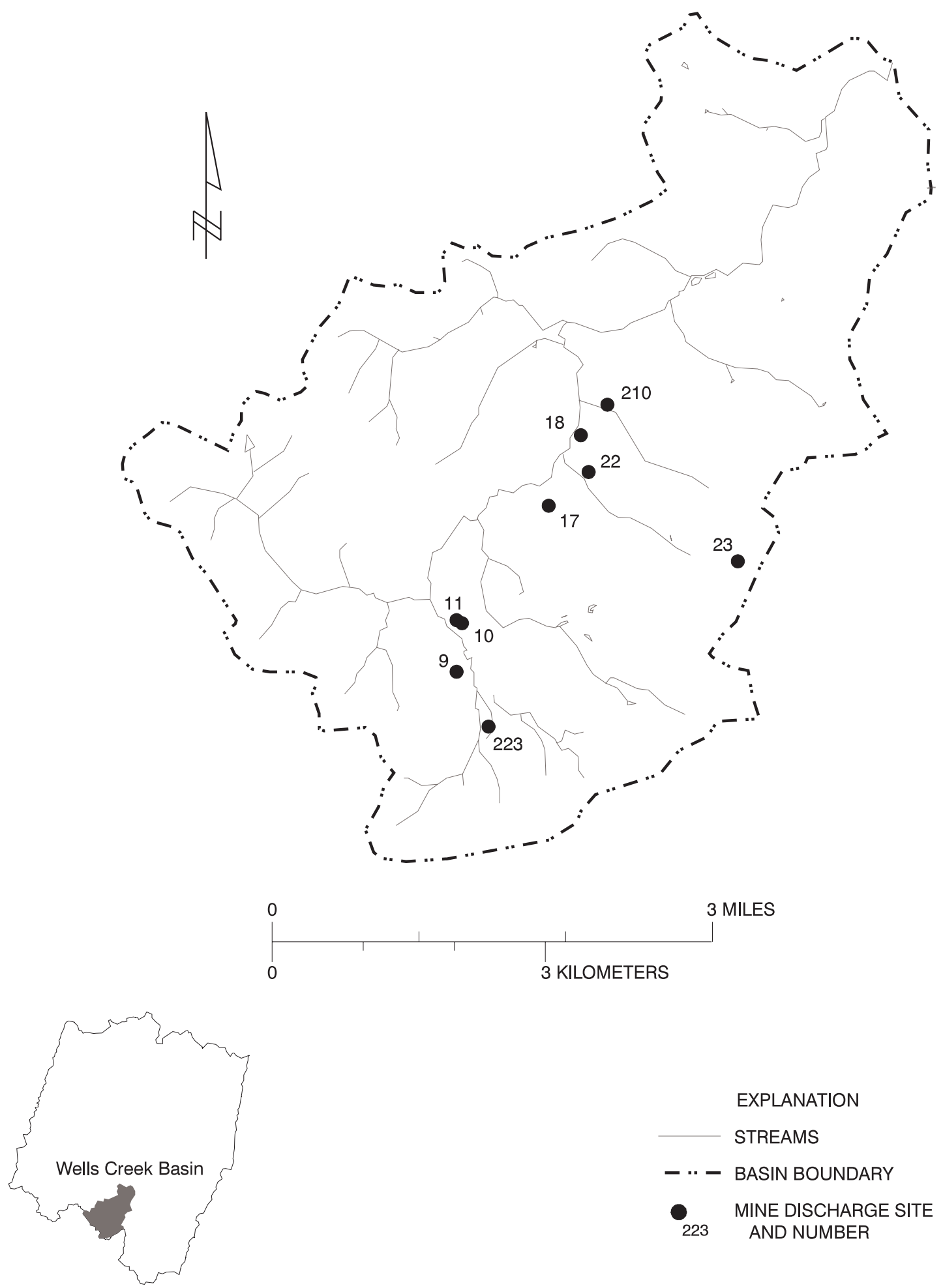

Stonycreek River Basin

Figure 8. Location of the coal-mine-discharge sites in the Wells Creek Basin. 


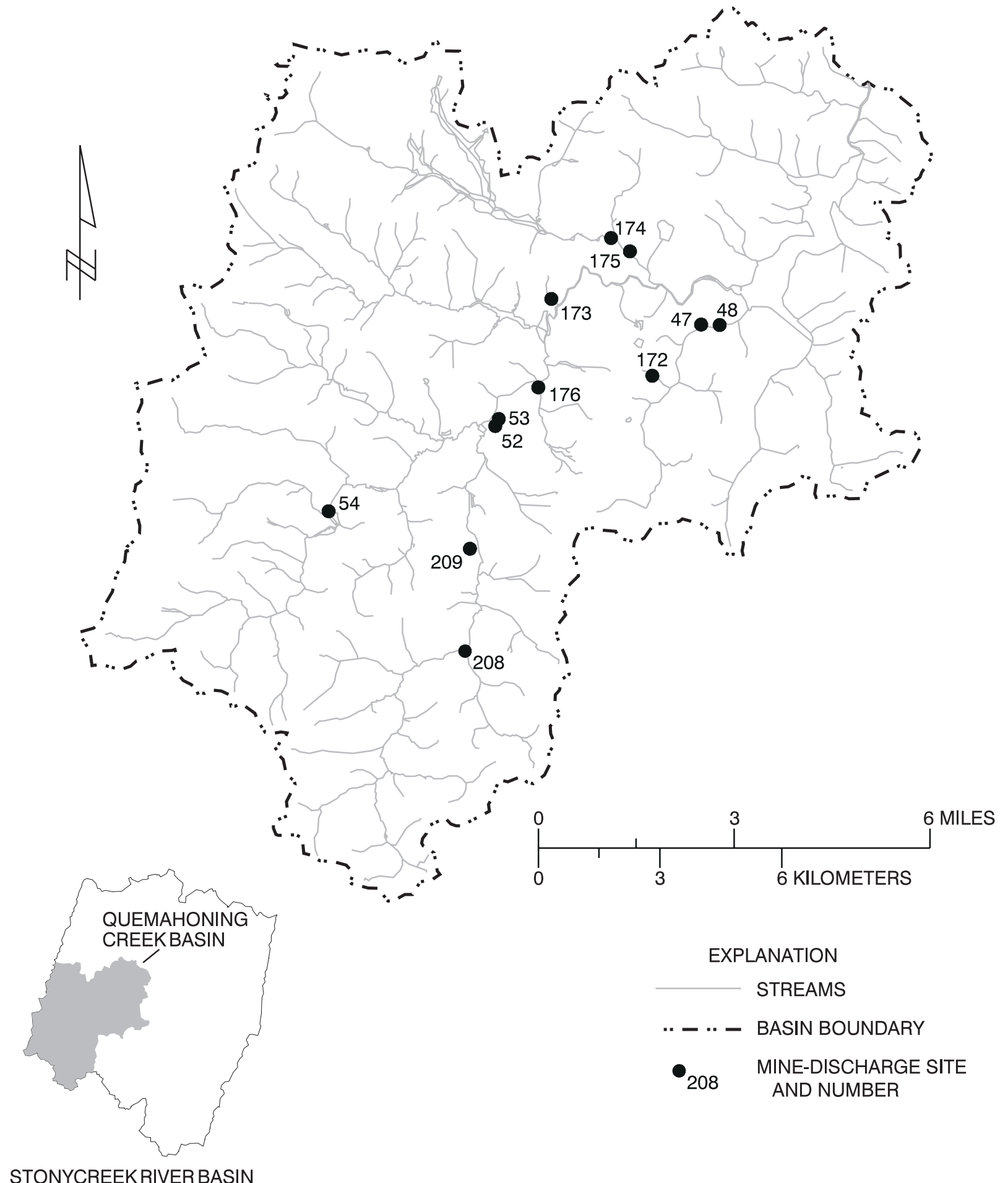

STONYCREEKRIVERBASIN

Figure 9. Location of the coal-mine-discharge sites in the Quemahoning Creek Basin. 


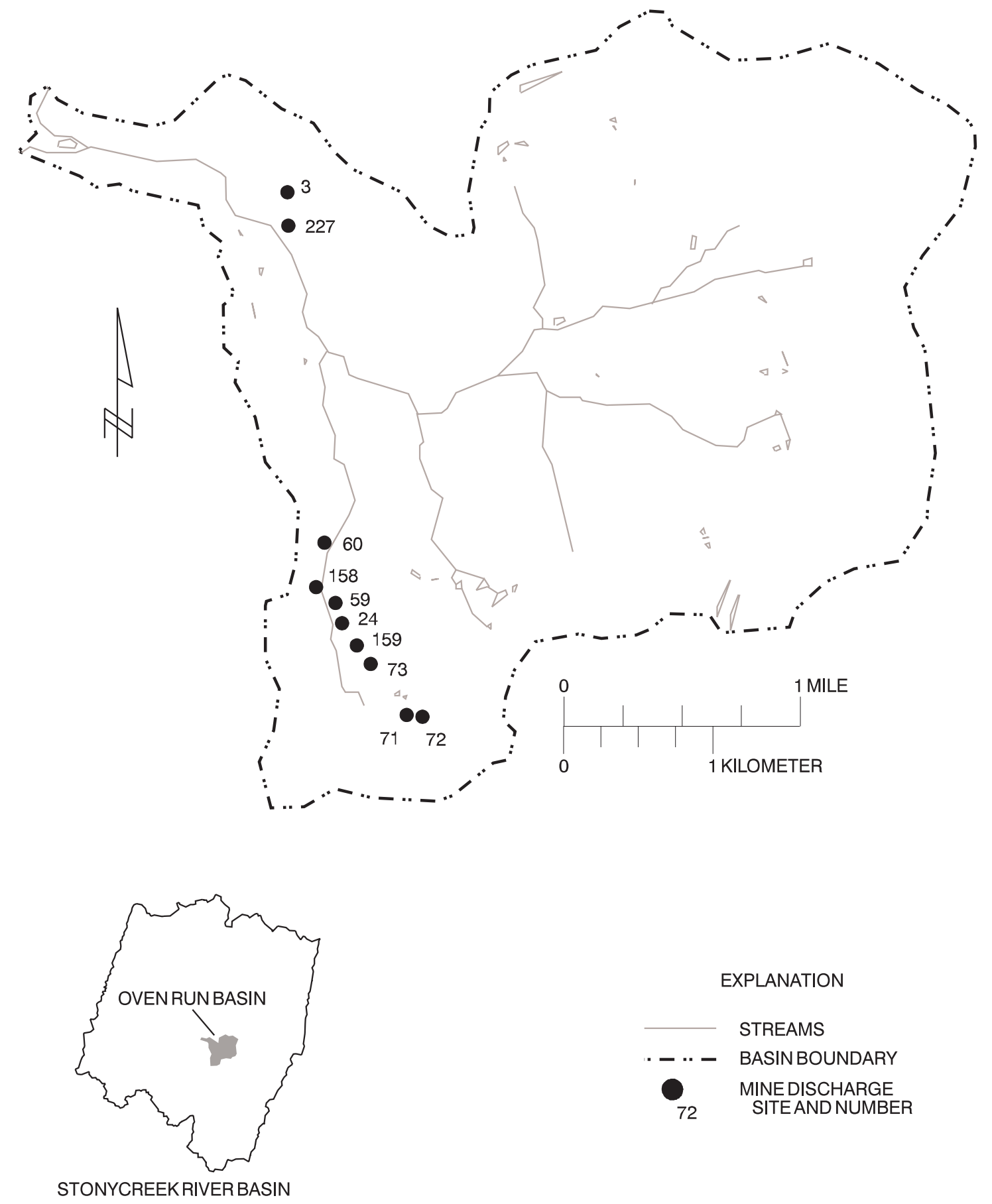

Figure 10. Location of the coal-mine-discharge sites in the Oven Run Basin. 

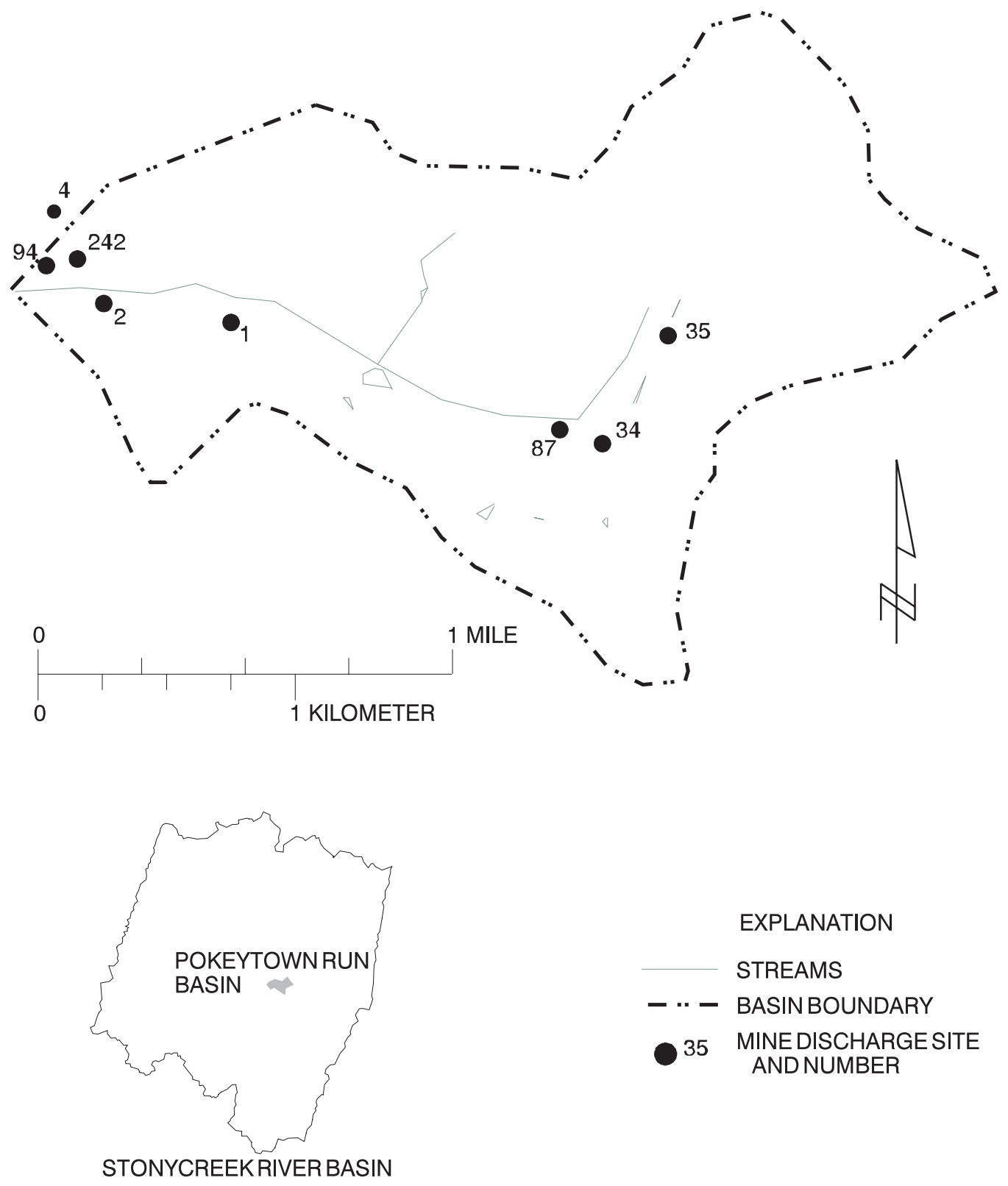

Figure 11. Location of the coal-mine-discharge sites in the Pokeytown Run Basin. 


\section{$\underline{\text { Remediation by Passive-Treatment Systems }}$}

Within the last decade, passive-treatment systems have developed from an experimental concept to full-scale field implementation at hundreds of sites (Hedin and others, 1994). Passive technologies take advantage of natural chemical and biological processes that improve the quality of contaminated water. Passive-treatment systems use contaminant removal processes that are slower than conventional treatment systems. Passive-treatment systems must retain contaminated mine water long enough to decrease contaminant concentrations to acceptable levels. The retention time for a particular mine discharge is limited by available land area, and therefore, the sizing of passive-treatment systems is a crucial design aspect. Baseline water quality and flow must be known to design AMD-treatment systems properly.

Three principal types of passive technologies are currently in use for the treatment of coal-mine drainage: aerobic wetland systems, wetlands that contain an organic substrate (compost wetlands), and ALD's. In aerobic wetland systems, oxidation reactions occur and metals precipitate primarily as oxides and hydroxides. Most aerobic wetlands contain cattails (Typha latifolia) growing in clay or spoil substrate. Plantless systems also have been constructed and function similarly to those containing plants if the influent water is alkaline. However, it is recommended that plants be included because they may help filter particulates, prevent flow channelization, and benefit wildlife. The water depth in a typical aerobic system is approximately 6 to $18 \mathrm{in}$.

Compost wetlands are similar to aerobic wetlands in form but also contain a thick layer of organic substrate. This substrate promotes chemical and microbial processes that generate alkalinity and neutralize acidic components of mine drainage. Typical substrates used in compost wetlands include spent mushroom compost, Sphagnum peat, hay bales, and manure.

ALD's are commonly used to treat AMD before it flows into a constructed wetland. The ALD raises the $\mathrm{pH}$ of the water to circumneutral levels ( $\mathrm{pH} 6$ to 7) and introduces bicarbonate alkalinity that neutralizes the acidity. When water exits the ALD, the circumneutral $\mathrm{pH}$ level promotes metal precipitation (Hedin and Narin, 1993). The limestone and mine water in an ALD are kept anoxic by sealing the drain to atmospheric oxygen to avoid armoring of the limestone with ferric hydroxide.

Each of the three passive technologies is most appropriate for a particular type of mine-water problem, but commonly, they are most effectively used in combination with each other. Examples are shown in figures 12 and 13. A passive-treatment system in which three ALD's, a constructed wetland, and two limestone cells are used in series to treat mine drainage from reclaimed surface mine spoils that were approximately 10 years old is shown in figure 12. This passive-treatment system is at an experimental site of the U.S. Bureau of Mines in the Shade Creek Basin, a subbasin of the Stonycreek River Basin. Kepler and McCleary (1994) have conducted research on a system called a successive alkalinity-producing system (SAPS) that combines ALD technology with the sulfate reduction mechanism of the compost wetland. A typical cross-sectional view of a SAPS treatment component is shown in figure 13. This system can be used to treat mine drainage that is extremely acidic (acidity concentration greater than $300 \mathrm{mg} / \mathrm{L}$ as $\mathrm{CaCO}_{3}$ ) and has high concentrations of ferric iron (concentrations greater than $1.0 \mathrm{mg} / \mathrm{L}$ ). A series of SAPS is commonly utilized until the AMD either meets effluent criteria or the quality of the AMD improves to the degree proportional to the area available for treatment. Passive treatment technology is still evolving and developing as researchers continue to work on perfecting these treatment systems. Although the effluent from these treatment systems at abandoned mine sites may not meet compliance standards, passive treatment may provide the only practical means of improving the quality of the mine discharge. Hedin and Narin (1992) provide an extensive listing of passive-treatment literature for water-resource managers who may be involved in the passive treatment of contaminated mine discharges. 


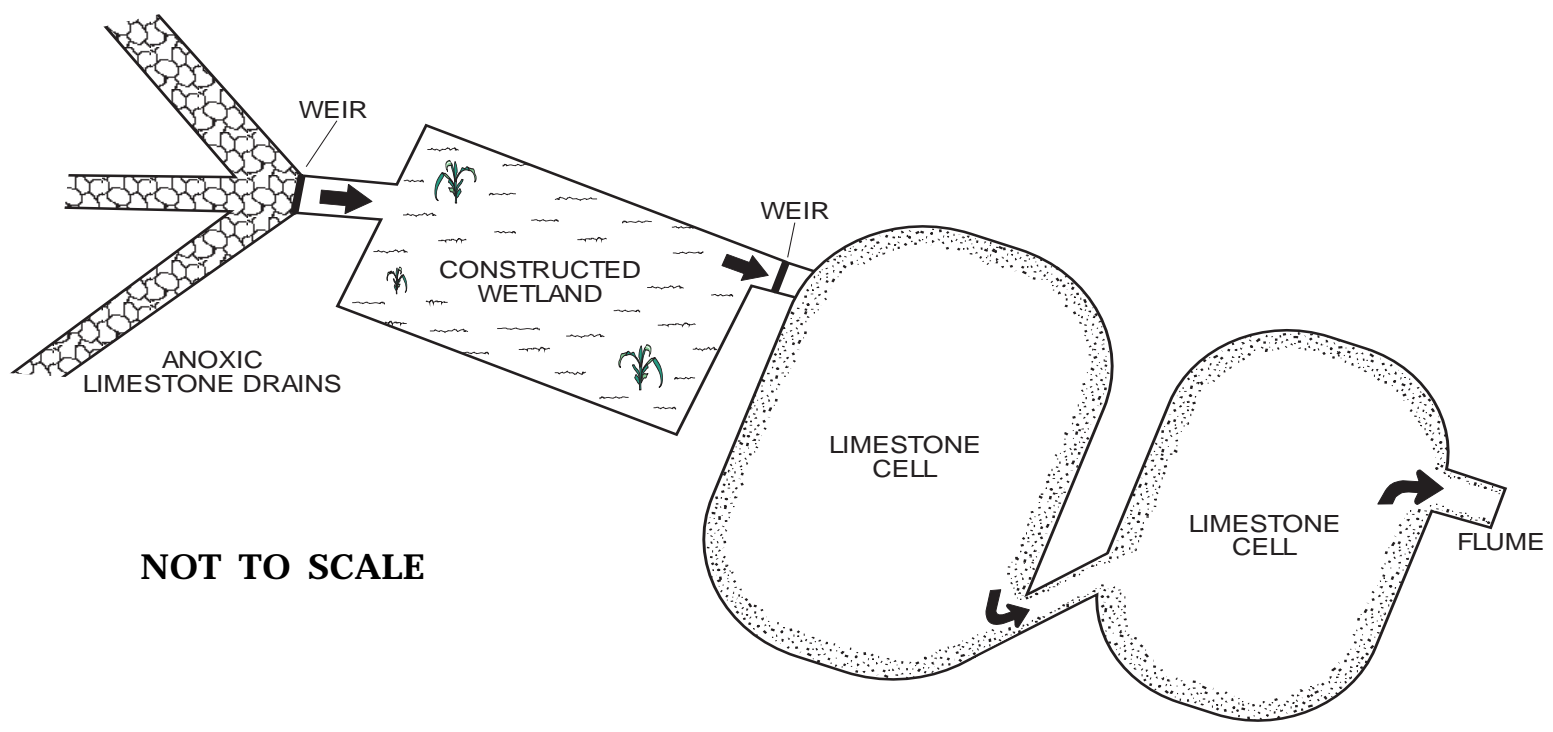

Figure 12. Layout of the Shade passive-treatment system in the Stonycreek River Basin (Modification from Narin and others, 1991).

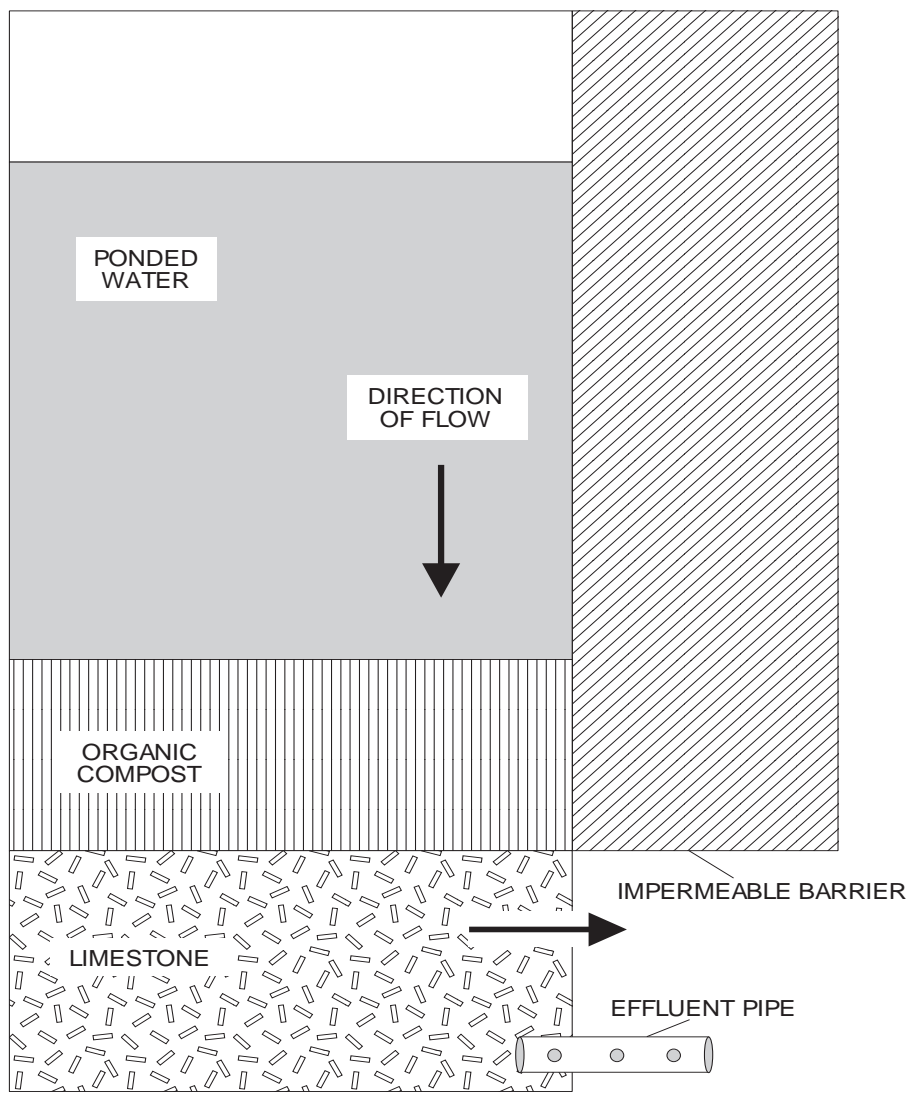

Figure 13. A typical cross-sectional view of a successive alkalinity-producing system treatment component (Kepler and McCleary, 1994, p. 198). 


\title{
SURFACE-WATER-QUALITY SAMPLING SITES
}

\author{
Locations
}

The 37 surface-water-quality sampling sites selected for this study are listed in table 12, and their locations are shown in figure 14 . The sites were selected to include a variety of stream-quality conditions. The sites consisted of mainstem sites, tributary sites, sites affected by varying degrees of mine drainage, sites designated as high quality or exceptional value streams by the PaDEP, inflows to reservoirs, reservoir outflows, and sites where historical data are available. Five sites were established on the Stonycreek River (sites 801-805) and 32 sites were on tributary streams (sites 806-837). Sites 805 and 833 are streamflowgaging stations where continuous streamflow data and periodic water-quality data are collected. Site 805 (Stonycreek River at Ferndale, Pa.) is $5.2 \mathrm{mi}$ upstream from the confluence with the Little Conemaugh River and has been a streamflow-gaging station since 1913. This site was established as the outflow site for the Stonycreek River Basin because of its proximity to the river mouth and the availability of long-term streamflow data and periodic water-quality data. Ninety-seven percent of the Stonycreek River Basin is monitored at site 805. Site 833 (North Fork Bens Creek at North Fork Reservoir) is the main inflow to the North Fork Reservoir, a water-supply reservoir serving the greater Johnstown area. Data were collected at this site from 1984 to 1993 as part of a nationwide network to determine long-term effects of acid precipitation on base-flow stream quality (Aulenbach and others, 1996). Data collection was continued at this site in 1994 for this investigation. Site 801 is a mainstem site in the headwaters of the Stonycreek River and is, for the most part, unaffected by mine drainage. Sites $802-804$ are mainstem sites at the towns of Kantner, Blough, and near Windber, respectively, and are affected by varying degrees of mine drainage. Eight tributary sites (sites $813,814,818,824,826,829,832$ and 834) were previously sampled by the USGS during 1979-81 (Herb and others, 1981) as part of a monitoring network to collect hydrologic data in coalbearing areas. Site 831 was previously sampled by the USGS from 1983 to 1986 to determine the effect of acid precipitation on stream-water quality (Barker and Witt III, 1990). Site 808 is a discontinued streamflow-gaging station on Clear Run operated by the USGS from 1961 to 1978 . The remaining sites were near the mouth of tributary streams in the Stonycreek River Basin and at inflows to the Quemahoning Reservoir (sites 818-823), Indian Lake (sites 808 and 809), and Lake Stonycreek (site 807). Site 817 was at the outflow of the Quemahoning Reservoir and site 810 was at the outflow of Lake Stonycreek and Indian Lake. 
Table 12. Surface-water-quality sampling sites in the Stonycreek River Basin

[', degrees; ', minutes; ", seconds; --, no drainage area available]

\begin{tabular}{|c|c|c|c|c|c|}
\hline \multirow[b]{2}{*}{$\begin{array}{c}\text { Site } \\
\text { number }\end{array}$} & \multirow[b]{2}{*}{$\begin{array}{c}\text { Station } \\
\text { number }^{1}\end{array}$} & \multicolumn{2}{|c|}{ Location } & \multirow[b]{2}{*}{ Station name } & \multirow[b]{2}{*}{$\begin{array}{c}\text { Drainage } \\
\text { area }\end{array}$} \\
\hline & & Latitude & Longitude & & \\
\hline 801 & & $40^{\circ} 00^{\prime} 14^{\prime \prime}$ & $078^{\circ} 54^{\prime} 02^{\prime \prime}$ & Stonycreek River at Shanksville & \\
\hline 802 & & $40^{\circ} 06^{\prime} 11^{\prime \prime}$ & $078^{\circ} 55^{\prime} 58^{\prime \prime}$ & Stonycreek River at Kantner & -- \\
\hline 803 & & $40^{\circ} 10^{\prime} 18^{\prime \prime}$ & $078^{\circ} 54^{\prime} 29^{\prime \prime}$ & Stonycreek River at Blough & -- \\
\hline 804 & & $40^{\circ} 14^{\prime} 37^{\prime \prime}$ & $078^{\circ} 53^{\prime} 02^{\prime \prime}$ & Stonycreek River near Windber & -- \\
\hline 805 & 03040000 & $40^{\circ} 17^{\prime} 08^{\prime \prime}$ & $078^{\circ} 55^{\prime} 15^{\prime \prime}$ & Stonycreek River at Ferndale & 451 \\
\hline 806 & & $39^{\circ} 58^{\prime} 36^{\prime \prime}$ & $078^{\circ} 55^{\prime} 49^{\prime \prime}$ & Glades Creek near Shanksville & -- \\
\hline 807 & & $40^{\circ} 00^{\prime} 33^{\prime \prime}$ & $078^{\circ} 51^{\prime} 16^{\prime \prime}$ & Boone Run near Shanksville & -- \\
\hline 808 & 03039200 & $40^{\circ} 02^{\prime} 50^{\prime \prime}$ & $078^{\circ} 49^{\prime} 58^{\prime \prime}$ & Clear Run near Buckstown & 3.68 \\
\hline 809 & & $40^{\circ} 03^{\prime} 37^{\prime \prime}$ & $078^{\circ} 51^{\prime} 37^{\prime \prime}$ & Calendars Run at Bucktown & -- \\
\hline 810 & & $40^{\circ} 00^{\prime} 56^{\prime \prime}$ & $078^{\circ} 54^{\prime} 05^{\prime \prime}$ & Rhoads Creek at Shanksville & 26.1 \\
\hline 811 & & $40^{\circ} 00^{\prime} 58^{\prime \prime}$ & $078^{\circ} 55^{\prime} 23^{\prime \prime}$ & Shrock Run near Shanksville & -- \\
\hline 812 & & $40^{\circ} 04^{\prime} 14^{\prime \prime}$ & $078^{\circ} 54^{\prime} 51^{\prime \prime}$ & Lamberts Run at Lambertsville & -- \\
\hline 813 & 03039300 & $40^{\circ} 04^{\prime} 11^{\prime \prime}$ & $078^{\circ} 56^{\prime} 45^{\prime \prime}$ & Wells Creek at Mostoller & 16.8 \\
\hline 814 & 03039340 & $40^{\circ} 05^{\prime} 35^{\prime \prime}$ & $078^{\circ} 57^{\prime} 16^{\prime \prime}$ & Beaverdam Creek at Stoystown & 18.5 \\
\hline 815 & & $40^{\circ} 07^{\prime} 06^{\prime \prime}$ & $078^{\circ} 55^{\prime} 28^{\prime \prime}$ & Oven Run at Rowena & -- \\
\hline 816 & & $40^{\circ} 08^{\prime} 41^{\prime \prime}$ & $078^{\circ} 54^{\prime} 49^{\prime \prime}$ & Fallen Timber Run at Hooversville & 2.48 \\
\hline 817 & & $40^{\circ} 11^{\prime} 21^{\prime \prime}$ & $078^{\circ} 56^{\prime} 28^{\prime \prime}$ & $\begin{array}{l}\text { Quemahoning Creek at Quemahoning } \\
\text { Reservoir Outflow }\end{array}$ & 98.2 \\
\hline 818 & 03039440 & $40^{\circ} 09^{\prime} 54^{\prime \prime}$ & $079^{\circ} 01^{\prime} 51^{\prime \prime}$ & Quemahoning Creek at Boswell & 58.5 \\
\hline 819 & & $40^{\circ} 09^{\prime} 54^{\prime \prime}$ & $079^{\circ} 04^{\prime} 05^{\prime \prime}$ & Beaverdam Creek at Jennerstown & -- \\
\hline 820 & & $40^{\circ} 08^{\prime} 22^{\prime \prime}$ & $079^{\circ} 03^{\prime} 59^{\prime \prime}$ & N Br Quemahoning Ck near Coal Junction & -- \\
\hline 821 & & $40^{\circ} 10^{\prime} 17^{\prime \prime}$ & $079^{\circ} 00^{\prime} 53^{\prime \prime}$ & Roaring Run at Pilltown & -- \\
\hline 822 & & $40^{\circ} 09^{\prime} 08^{\prime \prime}$ & $078^{\circ} 58^{\prime} 57^{\prime \prime}$ & Twomile Run near Boswell & 5.52 \\
\hline 823 & & $40^{\circ} 08^{\prime} 26^{\prime \prime}$ & $078^{\circ} 58^{\prime} 04^{\prime \prime}$ & Higgins Run near Boswell & 5.81 \\
\hline 824 & 03039700 & $40^{\circ} 06^{\prime} 18^{\prime \prime}$ & $078^{\circ} 47^{\prime} 55^{\prime \prime}$ & Dark Shade Creek at Central City & 8.51 \\
\hline 825 & & $40^{\circ} 07^{\prime} 01^{\prime \prime}$ & $078^{\circ} 48^{\prime} 16^{\prime \prime}$ & Laurel Run at Central City & 10.0 \\
\hline 826 & 03039750 & $40^{\circ} 08^{\prime} 03^{\prime \prime}$ & $078^{\circ} 48^{\prime} 53^{\prime \prime}$ & Dark Shade Creek at Reitz & 35.8 \\
\hline 827 & & $40^{\circ} 08^{\prime} 54^{\prime \prime}$ & $078^{\circ} 49^{\prime} 02^{\prime \prime}$ & Clear Shade Creek at Reitz & 31.4 \\
\hline 828 & & $40^{\circ} 10^{\prime} 59^{\prime \prime}$ & $078^{\circ} 49^{\prime} 52^{\prime \prime}$ & Roaring Fork near Hillsboro & -- \\
\hline 829 & 03039930 & $4914^{\prime} 46^{\prime \prime}$ & $078^{\circ} 50^{\prime} 49^{\prime \prime}$ & Little Paint Creek at Scalp Level & 12.4 \\
\hline 830 & & $40^{\circ} 14^{\prime} 41^{\prime \prime}$ & $078^{\circ} 53^{\prime} 02^{\prime \prime}$ & Paint Creek near Windber & 36.8 \\
\hline 831 & 03039930 & $40^{\circ} 23^{\prime} 41^{\prime \prime}$ & $079^{\circ} 02^{\prime} 49^{\prime \prime}$ & South Fork Bens Creek near Thomasdale & 3.28 \\
\hline 832 & 03039950 & $40^{\circ} 15^{\prime} 02^{\prime \prime}$ & $078^{\circ} 58^{\prime} 20^{\prime \prime}$ & South Fork Bens Creek near Ferndale & 18.1 \\
\hline 833 & 03039925 & $40^{\circ} 15^{\prime} 58^{\prime \prime}$ & $079^{\circ} 01^{\prime} 01^{\prime \prime}$ & North Fork Bens Creek at North Fork Res & 3.45 \\
\hline 834 & 03039957 & $40^{\circ} 16^{\prime} 58^{\prime \prime}$ & $078^{\circ} 56^{\prime} 10^{\prime \prime}$ & Bens Creek at Ferndale & 41.6 \\
\hline 835 & & $40^{\circ} 18^{\prime} 21^{\prime \prime}$ & $078^{\circ} 54^{\prime} 36^{\prime \prime}$ & Solomon Run at Johnstown & 8.47 \\
\hline 836 & & $40^{\circ} 12^{\prime} 43^{\prime \prime}$ & $078^{\circ} 53^{\prime} 55^{\prime \prime}$ & Shade Creek at Seanor & 96.7 \\
\hline 837 & & $40^{\circ} 07^{\prime} 38^{\prime \prime}$ & $078^{\circ} 55^{\prime} 28^{\prime \prime}$ & Pokeytown Run at Wilbur & -- \\
\hline
\end{tabular}

${ }^{1}$ For sites that have no station number listed, the station number is the 15 digit number that includes the latitude, longitude, and a 01 identifier at the end. For example, the station number for site 801 would be 400014078540201. 


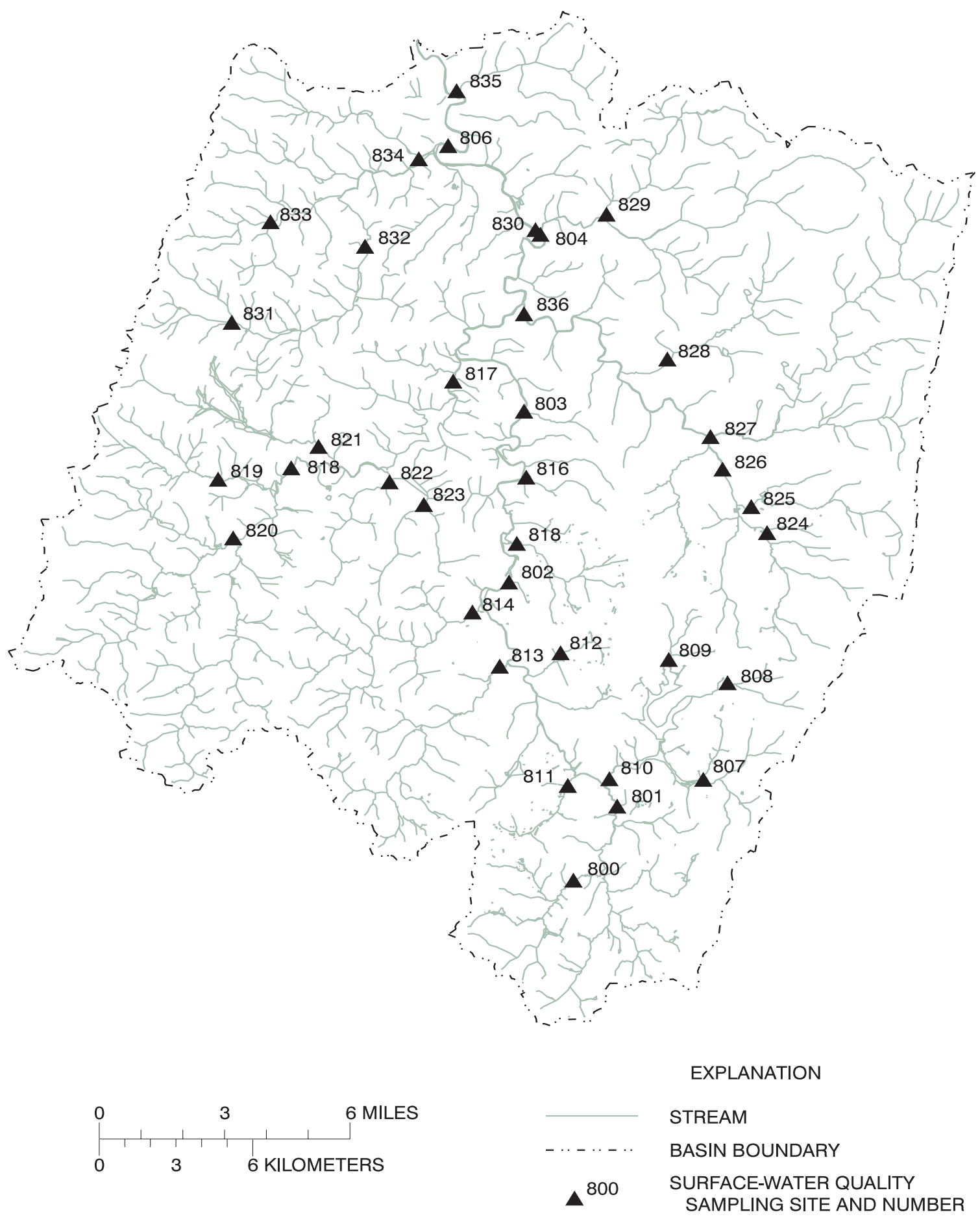

Figure 14. Surface-water-quality sampling sites in the Stonycreek River Basin. 


\section{Water Quality and Contaminant Discharges}

In order to determine base-flow stream quality and contaminant discharges, synoptic-sampling was conducted each year from 1992 through 1994 at the surface-water sites. Because no precipitation occurred within 5 days of each sampling period, any effects of direct surface runoff to the streams were eliminated. Consequently, the data provide a basinwide coverage of base-flow water quality. Low-base-flow samples were collected on September 1 and 2, 1992, and July 27 and 28, 1993, at the 63- and 76-percent flow durations at the Stonycreek River at Ferndale, Pa., respectively. High-base-flow samples were collected on May 23 and 24, 1994, at the 35-percent flow duration. Surface-water-quality analyses are presented in appendix 5. Samples collected on July 27 and 28, 1993, were during the lowest base-flow conditions of the three synoptic runs and are used to describe base-flow water quality throughout the basin. Specific conductance, $\mathrm{pH}$, and concentrations and discharges of dissolved solids, alkalinity, acidity, total iron, total manganese, and sulfate in the mainstem and tributary streams in the Stonycreek River Basin are shown on figures 15-18.

The $\mathrm{pH}$ at mainstem sites 801 and 802 was near neutral, but at mainstem sites $803-805$, the $\mathrm{pH}$ was 4.2 or less (fig. 15). The $\mathrm{pH}$ from the mainstem corresponds with changes in the alkalinity and acidity on the mainstem (fig. 16). As the $\mathrm{pH}$ decreased, the alkalinity decreased and the acidity increased. Alkalinity at mainstem site 801 and tributary streams between 801 and 802 effectively neutralizes most acidity in the mainstem at site 802 . However, the extremely high acidities at tributary sites 815 and 837 eliminate the neutralizing capability in the mainstem, and the mainstem remains acidic from site 803 to outflow site 805 . Tributary sites 836 and 830 also contribute significant acid discharges to the mainstem. Specific conductance and dissolved-solids concentrations do not significantly change from mainstem site 801 to mainstem site 805 because of dilution from tributary streams (fig. 15). However, specific conductance and dissolved-solids concentrations vary in the tributary streams. Dissolved-solids discharges gradually increase from mainstem sites 801 to 803 and then increase significantly at mainstem sites 804 and 805 . The large increases at sites 804 and 805 are the result of large dissolved-solids discharges entering the mainstem from tributary sites 830 and 836 and the increase in streamflow from site 804 to 805 .

Total-iron concentrations vary considerably spacially in both the mainstem and in the tributary streams (fig. 17). Chemical reactions occurring within the stream, which promote the oxidation and precipitation of iron, contribute to the variation in concentrations of iron. The discharge of total iron increased from $30 \mathrm{lb} / \mathrm{d}$ at mainstem site 801 to $684 \mathrm{lb} / \mathrm{d}$ at mainstem site 805 . The slight decrease in totaliron discharge from mainstem site 803 to site 804 was probably because of the precipitation of iron. Concentrations of total manganese also varied considerably in the mainstem and in the tributary streams (fig. 17). However, the discharge of total manganese increased considerably from mainstem site 802 to site 805. Very large discharges of manganese entered the mainstem from tributary sites 836 and 830 .

Manganese oxidation reactions and precipitation are strongly affected by $\mathrm{pH}$ and are very slow below $\mathrm{pH}$ 8.5. Therefore, the manganese entering the mainstem from the tributary streams did not precipitate and had an additive affect on mainstem discharges.

Sulfate concentrations are particularly high at tributary sites $812,815,830$, and 837 (fig. 18). Mainstem sulfate concentrations gradually increase from sites 801 to 803 and then gradually decrease from sites 803 to 805 . Neutralization reactions occurring in a stream generally do not change sulfate concentrations. The attenuation of the sulfate concentrations from mainstem sites 803 to 805 is probably because of dilution. Sulfate discharges gradually increase from mainstem sites 801 to 803 and significantly increase from sites 803 to 805 (fig. 18). The streamflow at sites 804 and 805 exceeded the streamflow at site 803 by 3.4 and 5.5 times, respectively, accounting for the large increase in sulfate discharges. 

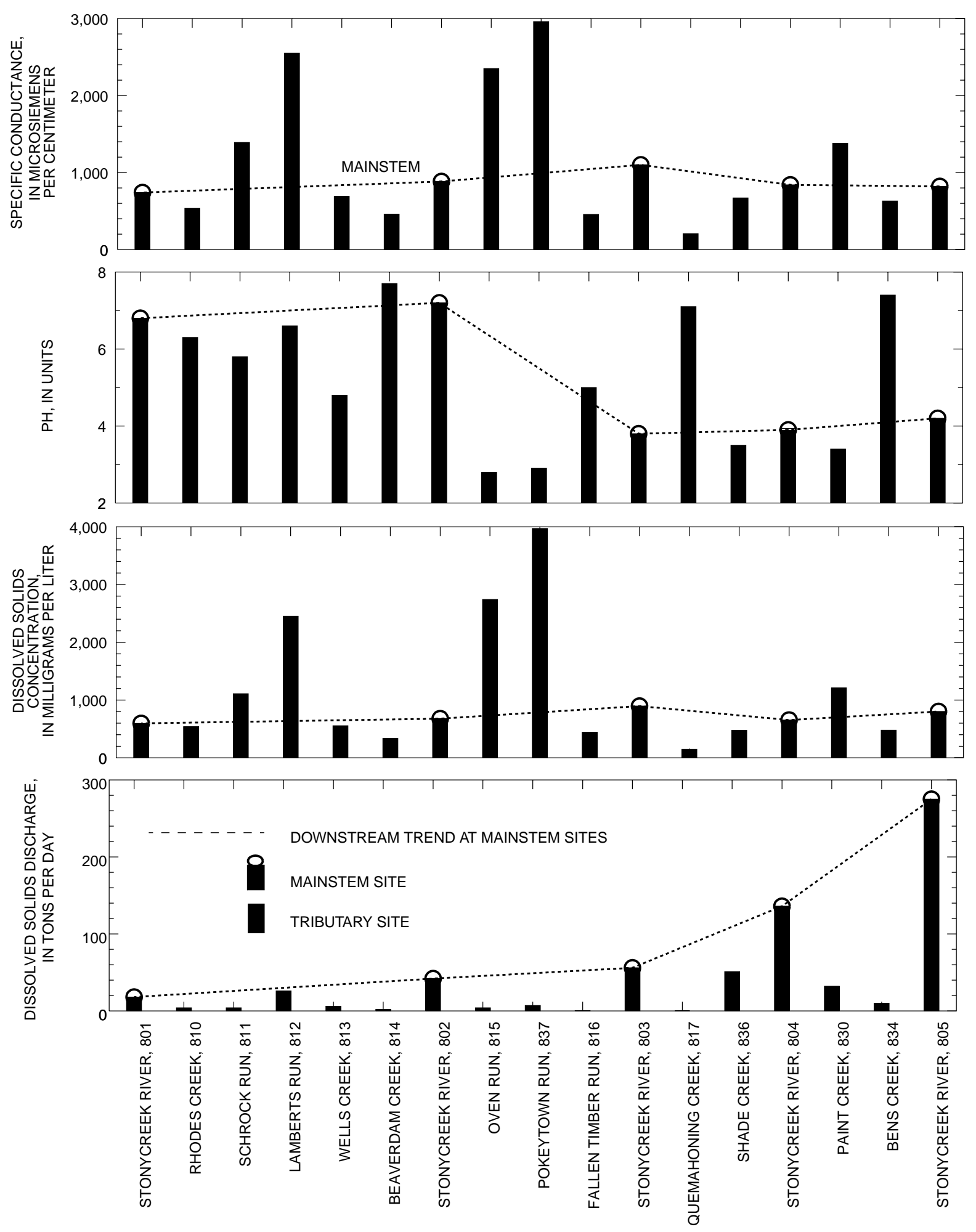

SITES, IN DOWNSTREAM ORDER FROM LEFT TO RIGHT

Figure 15. Specific conductance, $\mathrm{pH}$, and concentrations and discharges of dissolved solids measured in the mainstem and in tributary streams in the Stonycreek River Basin on July 27 and 28, 1993. 

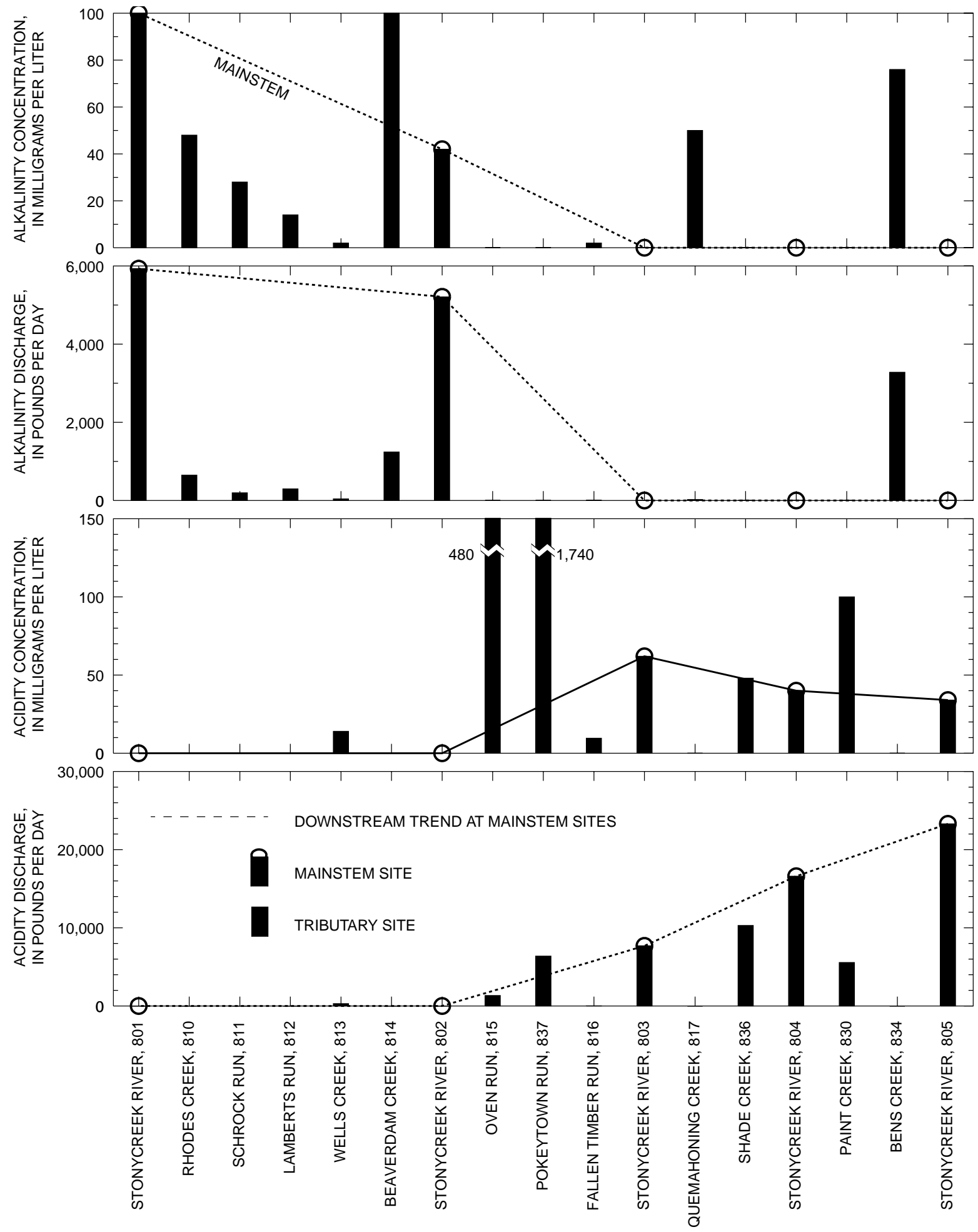

SITES, IN DOWNSTREAM ORDER FROM LEFT TO RIGHT

Figure 16. Concentrations and discharges of alkalinity and acidity measured in the mainstem and in tributary streams in the Stonycreek River Basin on July 27 and 28, 1993. 

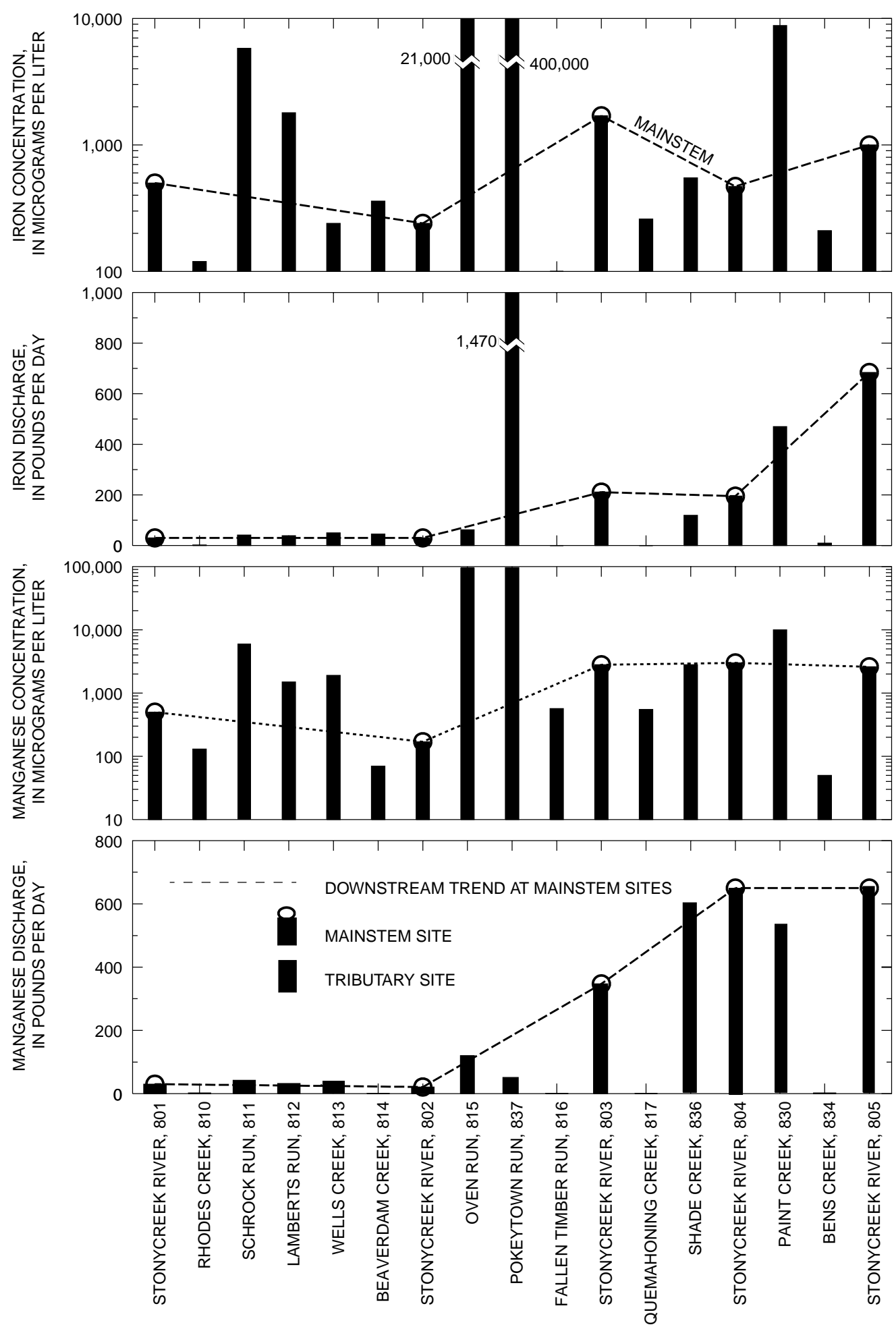

SITES, IN DOWNSTREAM ORDER FROM LEFT TO RIGHT

Figure 17. Concentrations and discharges of total iron and total manganese measured in the mainstem and in tributary streams in the Stonycreek River Basin on July 27 and 28, 1993. 

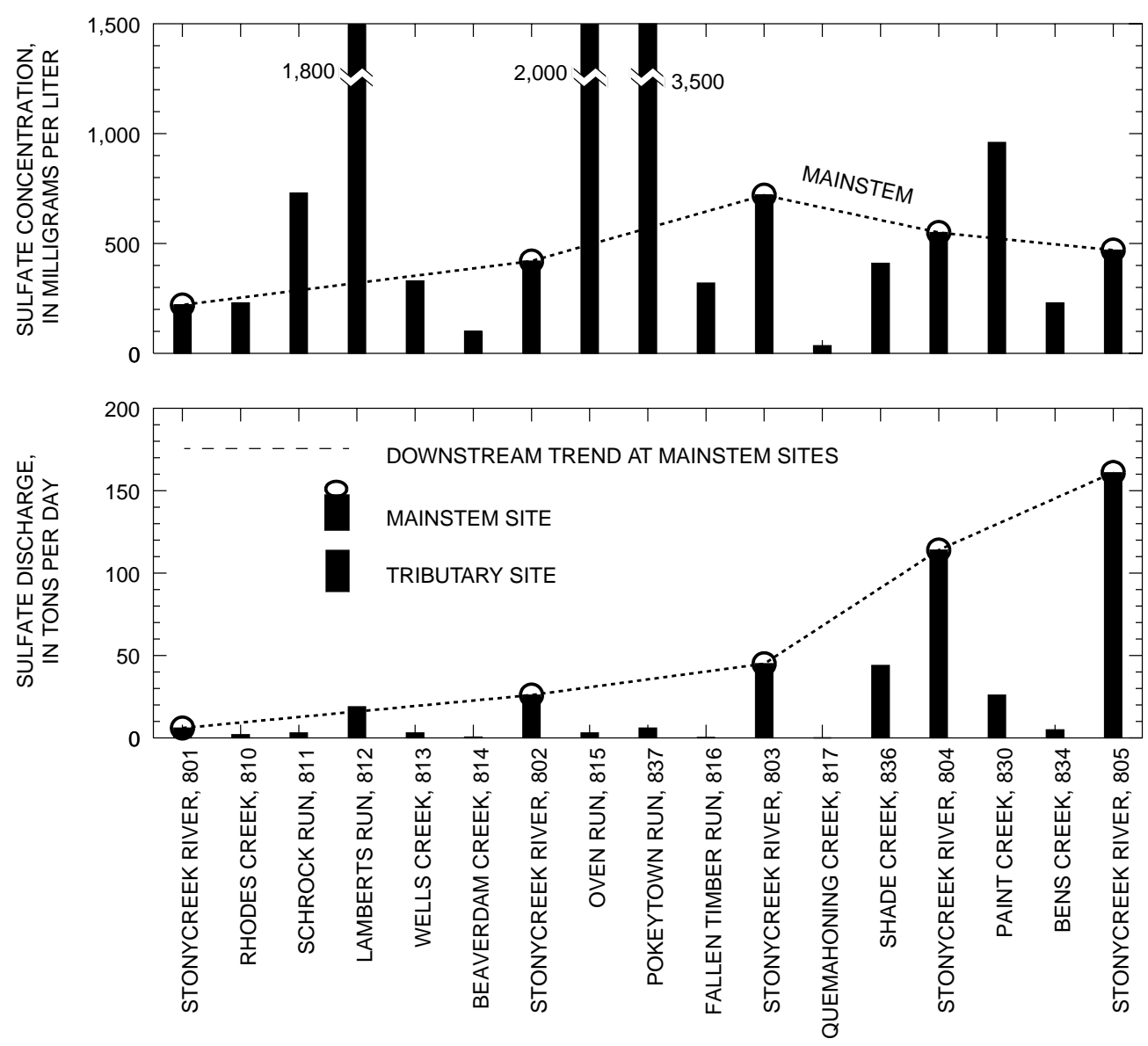

SITES, IN DOWNSTREAM ORDER FROM LEFT TO RIGHT

Figure 18. Concentrations and discharges of total sulfate measured in the mainstem and in tributary streams in the Stonycreek River Basin on July 27 and 28, 1993. 


\section{EFFECTS OF COAL-MINE DISCHARGE ON THE QUALITY OF STONYCREEK RIVER AND ITS TRIBUTARIES}

Coal-mine discharges affected surface-water quality throughout all of Appalachia. AMD continues to flow from some underground mines and coal refuse piles that are already a century old. In 1967, the Federal Water Pollution Control Administration (U. S. Department of the Interior, 1967) estimated that 78 percent of Appalachia's mine-drainage problems were from inactive and abandoned mines and coal refuse piles. However, with the enactment of the Surface Mining Control and Reclamation Act of 1977 and the establishment of effluent limitations for coal mining (Code of Federal Regulations, 1994), the total stream miles affected by mine drainage have decreased and inactive and abandoned mine sites now account for 99 percent of AMD problems in streams (Kleinman and others, 1988). This assessment is probably accurate for streams in the Stonycreek River Basin because effluents from all active mining operations must meet current effluent limitations (table 1).

When mine spoils containing sulfides are exposed to air and water, the sulfide minerals are oxidized by a series of microbial and chemical processes. The products of these reactions are carried into surface waters where they degrade water quality via acidification, metal contamination, and sedimentation. AMD waters are characterized by high metal and sulfate concentrations, high conductivity, and low pH (Mills, 1985).

Physical properties and chemical constituents varied during low-base flow on tributary streams and mainstem sites in the Stonycreek River Basin (figs. 15-18). Mine drainage flowing into a stream will affect most of those constituents. However, because of various physical and chemical processes such as precipitation, neutralization, and adsorption, changes in concentrations of stream constituents can occur that are not related to mine drainage. Sulfate is not affected by neutralization and precipitation processes and therefore, sulfate concentrations and discharges can be used as a reliable indicator of mine drainage in streams (Tolar, 1982, p.8). Bencala and others (1987) found that sulfate was an excellent conservative tracer of AMD in a stream system in Colorado. Very few processes act to remove sulfate from solution in stream water. The concentration of sulfate in streams depends on the amount produced at the source (a mine discharge) and the subsequent dilution in the stream. Dilution depends on streamflow, which can vary with factors such as precipitation and drainage area. Because of the dilution factor, sulfate concentrations cannot be compared from stream to stream as a reliable index of mine drainage. However, the resultant sulfate discharges can be compared from stream to stream or within a stream as a reliable indicator of mine drainage. The measured sulfate discharges of tributary streams and the measured and calculated sulfate discharges of the mainstem sites are shown in figure 19. The calculated mainstem discharges were determined by adding the upstream mainstem discharge with the measured downstream tributary discharges to determine the next mainstem discharge. For example, the sulfate discharge measured at mainstem site 801 (6 ton/d) was added to the discharges from tributary site 810 ( 2 ton/d), tributary site 811 (3 ton/d), tributary site 812 (19 ton/d), tributary site 813 (3 ton/d), and tributary site 814 (1 ton/d) to arrive at a calculated sulfate discharge of $34 \mathrm{ton} / \mathrm{d}$ at mainstem site 802 . The measured sulfate discharge at mainstem site 802 was 26 ton/d. A good correlation between the measured mainstem sulfate discharges and the calculated sulfate discharges is shown in figure 19. The calculated sulfate discharges at mainstem sites 803-805 were less than the measured discharges because sulfate discharges from some mine discharges that flow directly into the Stonycreek River were not measured. Sulfate discharges from Shade Creek (site 836) (44 ton/d) and Paint Creek (site 830) (26 ton/d) had the largest effect on sulfate discharges in the Stonycreek River.

Water-quality analyses from five mine discharges and the receiving streams above and below the mine discharges are presented in table 13. The water quality at mine-discharge site 14 did not affect Dark Shade Creek, primarily because that section of Dark Shade Creek was already severely affected by mine drainage. 


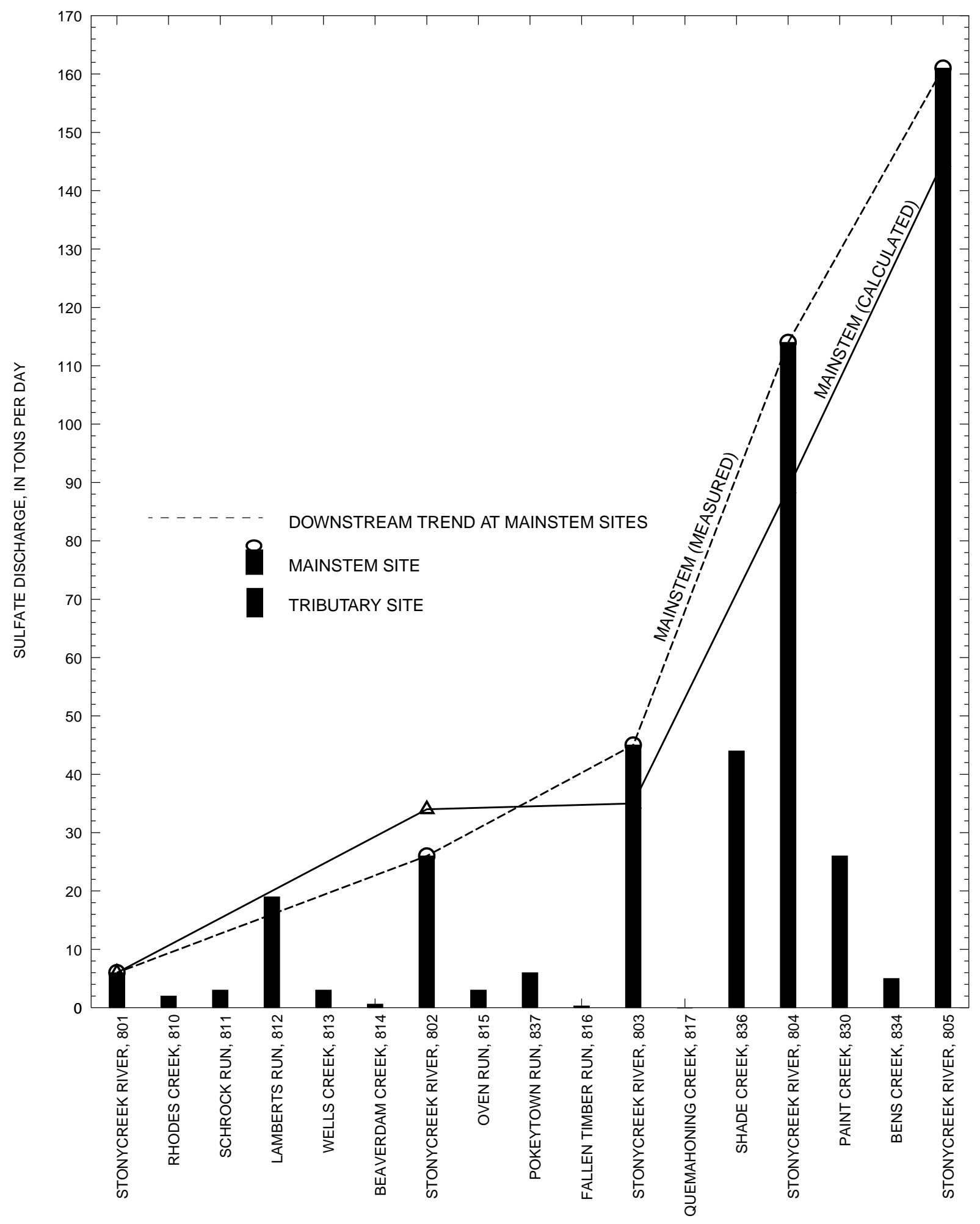

SITES, IN DOWNSTREAM ORDER FROM LEFT TO RIGHT

Figure 19. Measured total sulfate discharges in tributary streams and measured and calculated total sulfate discharges in the mainstem of the Stonycreek River on July 27 and 28, 1993. 
Table 13. Water-quality data for five coal-mine discharges and the receiving streams $[\mu \mathrm{g} / \mathrm{L}$, microgram per liter; $\mathrm{mg} / \mathrm{L}$, milligram per liter]

\begin{tabular}{|c|c|c|c|c|c|c|c|}
\hline Site & $\begin{array}{l}\text { Discharge, } \\
\text { instantaneous } \\
\text { (cubic feet } \\
\text { per second) }\end{array}$ & $\begin{array}{c}\mathrm{pH} \\
\text { (units) }\end{array}$ & $\begin{array}{l}\text { Iron, } \\
\text { total } \\
(\mu \mathrm{g} / \mathrm{L} \\
\text { as } \mathrm{Fe}\end{array}$ & $\begin{array}{c}\text { Manganese, } \\
\text { total } \\
(\mu \mathrm{g} / \mathrm{L} \\
\text { as } \mathrm{Mn})\end{array}$ & $\begin{array}{l}\text { Alkalinity } \\
(\mathrm{mg} / \mathrm{L} \text { as } \\
\left.\mathrm{CaCO}_{3}\right)\end{array}$ & $\begin{array}{c}\text { Acidity, } \\
\text { total } \\
\text { heated } \\
(\mathrm{mg} / \mathrm{L} \text { as } \\
\left.\mathrm{CaCO}_{3}\right)\end{array}$ & $\begin{array}{c}\text { Sulfate, } \\
\text { total } \\
(\mathrm{mg} / \mathrm{L} \\
\left.\text { as } \mathrm{SO}_{4}\right)\end{array}$ \\
\hline \multicolumn{8}{|c|}{ October 6, 1992} \\
\hline Dark Shade Creek above site 14 & 15.2 & 3.9 & 21,200 & 2,620 & 0 & 84 & 334 \\
\hline Site 14 & 1.51 & 3.7 & 1,980 & 6,860 & 0 & 100 & 678 \\
\hline Dark Shade Creek below site 14 & 17.5 & 3.9 & 19,200 & 2,910 & 0 & 82 & 342 \\
\hline \multicolumn{8}{|c|}{ October 6, 1992} \\
\hline Laurel Run above site 15 & 3.60 & 5.4 & 358 & 338 & 2.0 & 16 & 24 \\
\hline Site 15 & .12 & 3.5 & 57,400 & 13,300 & 0 & 230 & 799 \\
\hline Laurel Run below site 15 & 4.30 & 4.9 & 1,840 & 695 & 2.0 & 22 & 45 \\
\hline \multicolumn{8}{|c|}{ September 8, 1993} \\
\hline South Fork Bens Creek above site 178 & 1.68 & 7.4 & 681 & 454 & 46 & 0 & 89 \\
\hline Site 178 & 2.14 & 6.5 & 3,460 & 484 & 162 & 0 & 606 \\
\hline South Fork Bens Creek below site 178 & 3.82 & 6.8 & 2,650 & 468 & 110 & 0 & 344 \\
\hline \multicolumn{8}{|c|}{ September 9,1993} \\
\hline Wells Creek above site 17 & 1.22 & 7.2 & 199 & 462 & 26 & 0 & 233 \\
\hline Site 17 & .32 & 3.4 & 1,860 & 1,740 & 0 & 58 & 499 \\
\hline Wells Creek below site 17 & 1.54 & 6.4 & 804 & 742 & 12 & 0 & 243 \\
\hline \multicolumn{8}{|c|}{ May 12,1994} \\
\hline Wells Creek above site 17 & 19.1 & 6.8 & 1,050 & 303 & 11 & 0 & 83 \\
\hline Site 17 & 2.34 & 3.7 & 908 & 762 & 0 & 30 & 226 \\
\hline Wells Creek below site 17 & 21.4 & 6.4 & 1,030 & 358 & 7.4 & .8 & 90 \\
\hline \multicolumn{8}{|c|}{ September 9,1993} \\
\hline Wells Creek above site 22 & 1.52 & 6.3 & 806 & 752 & 10 & 3.6 & 243 \\
\hline Site 22 & .30 & 2.9 & 24,400 & 7,410 & 0 & 174 & 880 \\
\hline Wells Creek below site 22 & 1.82 & 3.9 & 5,160 & 1,930 & 0 & 32 & 406 \\
\hline \multicolumn{8}{|c|}{ May 12,1994} \\
\hline Wells Creek above site 22 & 23.4 & 6.4 & 1,330 & 378 & 7.4 & 4.4 & 91 \\
\hline Site 22 & 2.47 & 3.4 & 9,280 & 3,740 & 0 & 82 & 399 \\
\hline Wells Creek below site 22 & 25.8 & 5.3 & 2,240 & 733 & 2.2 & 6.2 & 115 \\
\hline
\end{tabular}


Mine discharge 15 did affect Laurel Run even though the flow of the mine discharge was only 3 percent of the flow in Laurel Run. Concentrations of total iron, total manganese, total sulfate, and acidity increased and $\mathrm{pH}$ decreased.

Mine discharge 178 is a treated mine discharge that had a significant effect on the South Fork Bens Creek. One positive effect was the addition of alkalinity to the stream. The discharge accounted for 56 percent of the streamflow in South Fork Bens Creek.

Mine discharges 17 and 22 flow into Wells Creek and were sampled during low- and high-base flow. Mine discharge 22 enters Wells Creek about $900 \mathrm{ft}$ downstream from where site 17 enters Wells Creek. These two discharges significantly affect the water quality of Wells Creek at both low- and high-base flow (table 13). Figure 20 graphically shows how these two mine discharges affect Wells Creek during low-base flow. The pH in Wells Creek decreased from 7.2 to 3.9. Stream alkalinity was completely depleted by the acidity of the two mine discharges. Sulfate discharges increased from 0.76 to 2.0 ton $/ \mathrm{d}$. Discharges of total iron increased from 1.3 to $51 \mathrm{lb} / \mathrm{d}$. Plots of the data from sites 17 and 22 collected on May 12, 1994 (not shown), show that the two mine discharges had a similar effect on Wells Creek during high-base flow as is shown on figure 20 for low-base flow. The discharges and concentrations were different, but the trends were similar. The PI in Appendix 4 shows that sites 17 and 22 are ranked 28th and 7th, respectively, for mine-discharge remediation in the Stonycreek River Basin. The PI in table 8 shows that sites 17 and 22 are ranked second and first, respectively, for mine-discharge remediation in the Wells Creek Basin.

Surface-water-quality data collected from the mouth of Oven Run (site 815) and Pokeytown Run (site 837) and from the Stonycreek River above and below where each of those runs flow into the river are given in table 14. Oven Run flows into the Stonycreek River near the town of Rowena. Pokeytown Run flows into the Stonycreek River approximately $0.5 \mathrm{mi}$ downstream from the Oven Run inflow. Both Oven Run and Pokeytown Run are severely affected by AMD, and each significantly deteriorates Stonycreek River water quality. The Oven Run outflow is the first source of highly degraded water from AMD into the Stonycreek River. Both have many mine discharges but a major discharge in each basin is responsible for most of the AMD in the two streams. Mine discharge site 3 has a significant effect on Oven Run, and mine discharge site 4 has a similar effect on Pokeytown Run. Mine discharges 3 and 4 ranked 8th and 5th, respectively, on the PI for the Stonycreek River Basin (Appendix 4). The flows at mine-discharge sites 3 and 4 on August 18, 1993, were 0.23 and $0.20 \mathrm{ft}^{3} / \mathrm{s}$, respectively. The streamflows in Oven Run and Pokeytown Run on September 8, 1993, at low-base flow were 0.56 and $0.41 \mathrm{ft}^{3} / \mathrm{s}$, respectively. If the discharges at the mine-discharge sites and the streamflow in the streams were similar on both days, minedischarge site 3 accounted for 41 percent of the streamflow in Oven Run and mine-discharge site 4 accounted for 49 percent of the streamflow in Pokeytown Run.

Table 14. Water-quality data collected on September 8, 1993, for Oven Run, Pokeytown Run, and the Stonycreek River above and below where each of the runs flows into the river

[ $\mu \mathrm{g} / \mathrm{L}$, microgram per liter; mg/L, milligram per liter]

\begin{tabular}{|c|c|c|c|c|c|c|c|}
\hline Site & $\begin{array}{c}\text { Discharge, } \\
\text { instantaneous } \\
\text { (cubic feet } \\
\text { per second) }\end{array}$ & $\begin{array}{c}\mathrm{pH} \\
\text { (units) }\end{array}$ & $\begin{array}{l}\text { Iron, } \\
\text { total } \\
(\mu \mathrm{g} / \mathrm{L} \\
\text { as Fe }\end{array}$ & $\begin{array}{c}\text { Manganese, } \\
\text { total } \\
(\mu \mathrm{g} / \mathrm{L} \\
\text { as } \mathrm{Mn})\end{array}$ & $\begin{array}{c}\text { Alkalinity } \\
\text { (mg/L as } \\
\left.\mathrm{CaCO}_{3}\right)\end{array}$ & $\begin{array}{c}\text { Acidity, } \\
\text { total } \\
\text { heated } \\
(\mathrm{mg} / \mathrm{L} \text { as } \\
\left.\mathrm{CaCO}_{3}\right)\end{array}$ & $\begin{array}{l}\text { Sulfate, } \\
\text { total } \\
(\mathrm{mg} / \mathrm{L} \\
\left.\text { as } \mathrm{SO}_{4}\right)\end{array}$ \\
\hline Stonycreek River above Oven Run & 17.4 & 7.6 & 309 & 296 & 42 & 0 & 382 \\
\hline Oven Run & .56 & 2.8 & 15,900 & 28,000 & 0 & 354 & 1,390 \\
\hline Stonycreek River below Oven Run & 18.0 & 7.2 & 769 & 1,310 & 38 & 0 & 415 \\
\hline Stonycreek River above Pokeytown Run & 23.0 & 6.3 & 599 & 1,410 & 32 & 0 & 472 \\
\hline Pokeytown Run & .41 & 2.7 & 490,000 & 13,600 & 0 & 2,180 & 4,120 \\
\hline Stonycreek River below Pokeytown Run & 23.4 & 5.1 & 14,000 & 1,860 & 2 & 50 & 644 \\
\hline
\end{tabular}



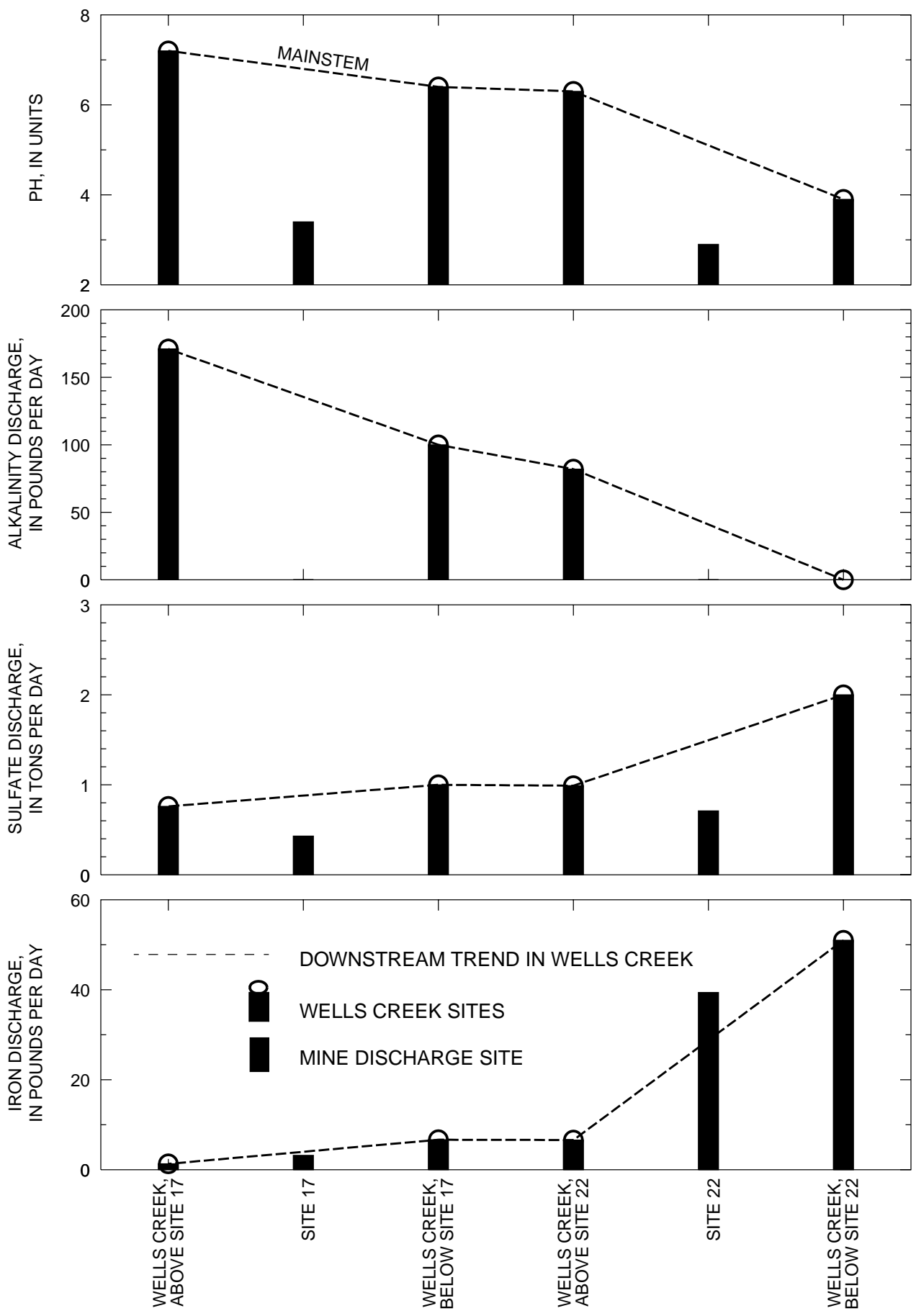

SITES, IN DOWNSTREAM ORDER FROM LEFT TO RIGHT

Figure 20. The effects of mine discharges 17 and 22 on Wells Creek on September 9,1993. 
The $\mathrm{pH}$ in the Stonycreek River decreased from 7.6 above Oven Run to 5.1 below Pokeytown Run (fig. 21). The alkalinity in the Stonycreek River was adequate to neutralize the acidity from Oven Run, but the large acidity discharges from Pokeytown Run almost eliminated the available alkalinity in the river. Alkalinity in the Stonycreek River decreased from $42 \mathrm{mg} / \mathrm{L}$ above Oven Run to $2 \mathrm{mg} / \mathrm{L}$ below Pokeytown Run. Sulfate discharges in the Stonycreek River were 18 ton/d above Oven Run and 41 ton/d below Pokeytown Run. Total-iron discharges increased slightly in the Stonycreek River from the Oven Run inflow, but dramatically increased in the river because of the Pokeytown Run inflow. Total-iron discharges increased from $29 \mathrm{lb} / \mathrm{d}$ above Oven Run to 1,770 lb/d below Pokeytown Run.

The U.S. Department of Agriculture, Natural Resources Conservation Service, in cooperation with the Somerset Conservation District, the Somerset County Commissioners, and SCRIP as a supporting sponsor, plans to design and construct passive-treatment systems for the remediation of mine discharges in the Oven Run and Pokeytown Run Basins. A watershed plan includes six specific mine-drainage abatement projects. The design phase for the projects will be from 1994 to 1997, and the construction phase will be from 1995 to 1998. Preliminary plans suggest that SAPS, settling ponds, and chambered passivetreatment-wetlands that use composted mushroom spoil and cattails will be used to treat the mine discharges. The treatment measures are expected to improve the water quality in the Stonycreek River in a 4-mi reach from Oven Run to the Borough of Hooversville. Residents in the borough of Hooversville and surrounding areas will benefit from this project because the Hooversville Water Authority obtains its water supply from the Stonycreek River.

The effects of Oven Run and Pokeytown Run on the water quality of the Stonycreek River are shown in figures 15-19 and figure 21. Shade Creek and Paint Creek had an even greater effect on the water quality in the Stonycreek River (figs. 15-19) and these two streams contribute more acid mine-affected water to the Stonycreek River than any other tributaries in the Stonycreek River Basin. The Shade Creek and Paint Creek Basins have been heavily mined and have many abandoned-mine discharges. Water-resouce managers are considering remediation action in these two basins after the completion of the remediation work in the Oven Run and Pokeytown Run Basins. 

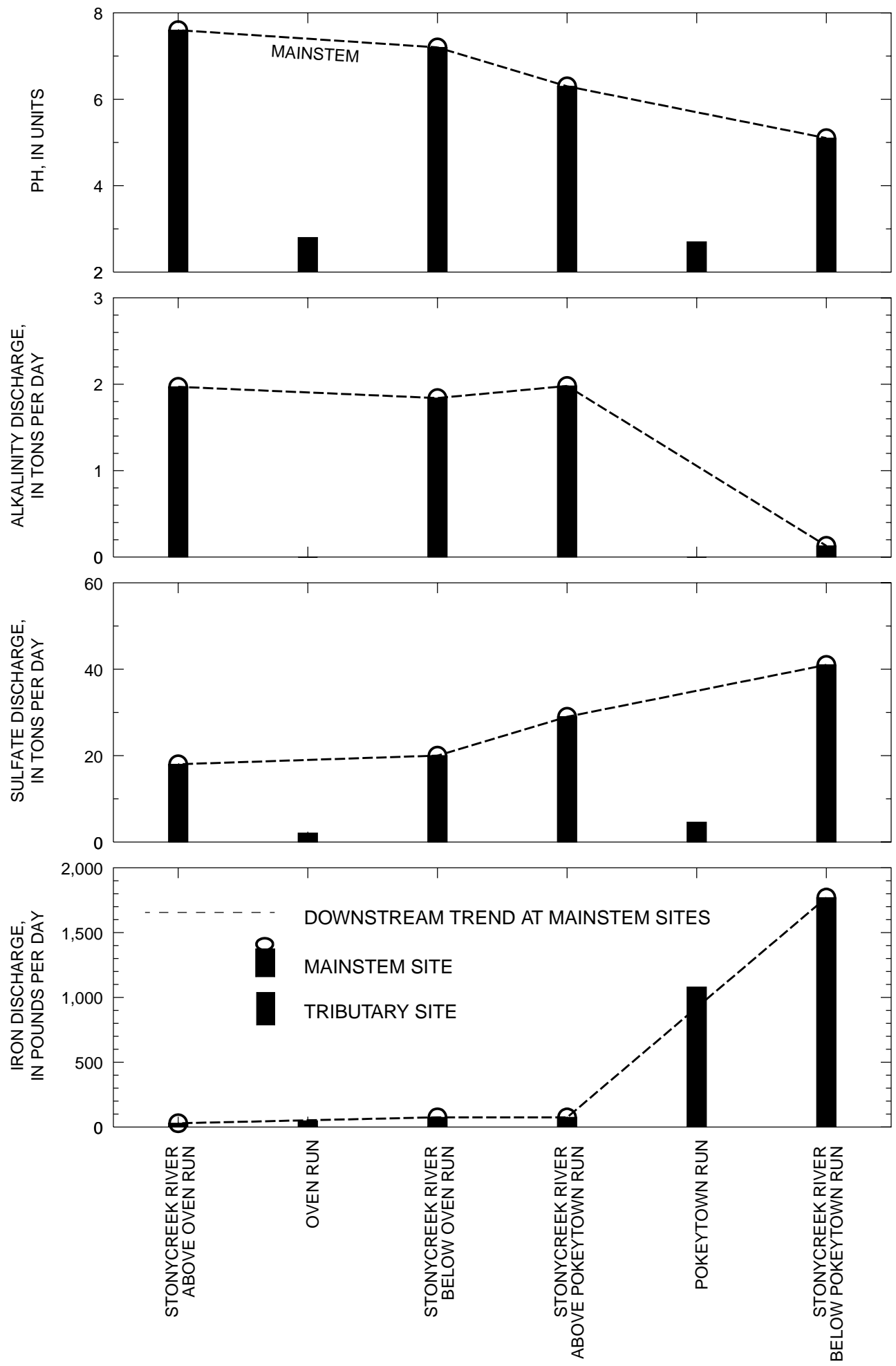

SITES, IN DOWNSTREAM ORDER FROM LEFT TO RIGHT

Figure 21. The effects of Oven Run and Pokeytown Run on the Stonycreek River on September 8, 1993. 


\section{SUMMARY}

The Stonycreek River Basin drains an area $468 \mathrm{mi}^{2}$ in Somerset and Cambria Counties in southwestern Pennsylvania. Fourteen different coal beds throughout the basin are of mineable thickness, however, the Lower and Upper Kittanning and the Upper Freeport coals are the three coal beds that have been most extensively mined. Commercial mining of the coal resources began in the late 1800's with almost no concern for the protection of the land surface or water resources. Consequently, the water quality of the Stonycreek River and its tributaries has been severely degraded for many decades by acidic coal-mine drainage. From October 1991 through November 1994, the USGS, in cooperation with the Somerset Conservation District, conducted an investigation throughout the Stonycreek River Basin to locate and sample abandoned mine discharges, to prioritize the discharges for remediation, and to determine the effects of the mine discharges on the water quality of the Stonycreek River and its major tributaries. The location of the 270 mine discharges that were sampled were determined by use of a GPS receiver with a horizontal accuracy of 3 to $10 \mathrm{ft}$.

The water quality of the mine discharges varied considerably from discharges that were extremely acidic with high concentrations of iron, manganese, aluminum, and sulfate to discharges whose water quality met USEPA drinking water standards for most constituents. Of the 270 mine discharges sampled, 193 discharges exceeded effluent standards for $\mathrm{pH}, 122$ discharges exceeded effluent standards for totaliron concentration, and 141 discharges exceeded effluent standards for total-manganese concentration. Ninety-four mine discharges exceeded effluent standards for $\mathrm{pH}$ and concentrations of total iron and total manganese; 38 mine discharges met effluent standards for all three constituents. Secondary drinking water standards for $\mathrm{pH}$, iron, manganese, aluminum, and fluoride were met at five mine discharges.

Streamflow was an important factor when determining the contaminant discharges of the mine discharges. Mine discharge at site 20 contained a total-iron concentration of 4,760 mg/L, highest of all 270 mine discharges, but a streamflow of only $0.7 \mathrm{gal} / \mathrm{min}$ ranked it 26th of all 270 discharges with respect to total-iron discharge. The mine discharges that contained high concentrations of contaminants in addition to large streamflows were the discharges that contributed most of the contaminant discharges to the receiving streams.

A primary goal of the Stonycreek River Basin study was to develop a system that would prioritize all mine discharges for remediation. A PI was developed that ranked the severity of each mine discharge by use of seven specific constituents. The constituents included $\mathrm{pH}$, streamflow, and discharges of total iron, total manganese, total heated acidity, total sulfate, and dissolved aluminum. The PI can be used by water-resource managers as a guide to determine which mine discharges have the greatest effect on stream-water quality and should be considered for remediation. A PI was developed for all mine discharges throughout the Stonycreek River Basin and for mine discharges in six subbasins that were moderately to severely effected by mine drainage. The subbasins were the Shade Creek, Paint Creek, Wells Creek, Quemahoning Creek, Oven Run, and Pokeytown Run Basins.

Water-resource managers propose to remediate the abandoned mine discharges by constructing passive-treatment systems that include aerobic wetlands, compost wetlands, and ALD's. Each of the three passive technologies is most appropriate for a particular type of mine water, but commonly, they are most effectively used in combination with each other. For mine discharges that are extremely acidic (acidity concentration greater than $300 \mathrm{mg} / \mathrm{L}$ as $\mathrm{CaCO}_{3}$ ) with high concentrations of ferric iron (concentrations greater than $1.0 \mathrm{mg} / \mathrm{L}$ ), the use of a SAPS would be most effective in treating the AMD. A SAPS combines ALD technology with the sulfate reduction mechanism of the compost wetland. A series of SAPS is commonly necessary until the AMD either meets effluent criteria or the limit of the area available for treatment is reached. 
A network of 37 surface-water sampling sites was established to identify stream water quality during base flow. Water samples collected on July 27 and 28, 1993, are used to describe base-flow quality throughout the basin. From mainstem site 801 to mainstem site 805, water-quality degradation occurred that is attributed to the inflows of acidic mine discharges from affected tributaries in addition to inflows of mine discharges directly into the river. Shade Creek, Paint Creek, Oven Run, and Pokeytown Run are tributaries that significantly affect river water quality. From mainstem site 801 to $805, \mathrm{pH}$ decreased from 6.8 to 4.2 , alkalinity was completely depleted, and discharges of total iron increased from 30 to $684 \mathrm{lb} / \mathrm{d}$. Very large discharges of manganese entered the mainstem from Shade Creek and Paint Creek. Manganese oxidation reactions and precipitation are strongly affected by $\mathrm{pH}$ and are very slow below $\mathrm{pH} 8.5$. The manganese entering the mainstem from the tributary streams did not precipitate and had an additive affect on mainstem discharges. The attenuation of sulfate concentrations from mainstem sites 803 to 805 is because of dilution, but the significant increase in sulfate discharges from sites 803 to 805 is the result of increased streamflow. A good correlation existed between the measured mainstem sulfate discharges and the calculated mainstem sulfate discharges. The sulfate discharges were calculated by adding the sulfate discharges of the previous upstream mainstem site to the sulfate discharges of all sampled tributary streams entering the river between the two mainstem sites.

Mine discharges 17 and 22 had a major effect on the water quality of Wells Creek. Mine discharge 22 enters Wells Creek about $900 \mathrm{ft}$ downstream from where mine discharge 17 enters Wells Creek. Data collected in Wells Creek above mine discharge 17 inflow and below mine discharge 22 inflow on September 9, 1993, show that $\mathrm{pH}$ decreased from 7.2 to 3.9 , stream alkalinity was completely depleted by the two mine discharge acidities, sulfate discharges increased from 0.76 to 2.0 ton/d, and total-iron discharges increased from 1.3 to $51 \mathrm{lb} / \mathrm{d}$. The PI for mine discharges 17 and 22 rank them 28th and 7th, respectively, for mine-discharge remediation in the Stonycreek River Basin. Oven Run and Pokeytown Run had a similar effect on the water quality of the Stonycreek River. Both streams are significantly affected by AMD and are the first major sources of AMD flowing into the Stonycreek River. The Pokeytown Run inflow is about $0.5 \mathrm{mi}$ downstream from the Oven Run inflow. Both basins contain many mine discharges, but one major discharge in each basin is responsible for much of the AMD in each stream. Mine discharge at site 3 has a large effect on Oven Run, and mine discharge at site 4 has a similar effect on Pokeytown Run. Mine discharges at sites 3 and 4 ranked 8th and 4th, respectively, on the PI for the Stonycreek River Basin. Data collected in the Stonycreek River above Oven Run and below Pokeytown Run during low-base flow on September 8, 1993, show a decrease in $\mathrm{pH}$ from 7.6 to 5.1, a decrease in alkalinity from 42 to $2 \mathrm{mg} / \mathrm{L}$, an increase in sulfate discharges from 18 to $41 \mathrm{ton} / \mathrm{d}$, and an increase in total-iron discharges from 29 to 1,770 lb/d. The U.S. Department of Agriculture, Natural Resources Conservation Service, in cooperation with the Somerset Conservation District, the Somerset County Commissioners, and SCRIP as a supporting sponsor, plans to design and construct passive-treatment systems for the remediation of mine discharges in the Oven Run and Pokeytown Run Basins. The design phase for the projects will occur during 1994-97, and the construction phase will occur during 1995-98. 


\section{REFERENCES CITED}

Anderson, J.R., 1967, Major land uses in the United States, in U.S. Geological Survey, 1970, National atlas of the United States of America: Washington, D.C., U.S. Geological Survey, p. 158-159.

Aulenbach, B.T., Hooper, R.P., and Bricker, O.P., 1996, Trends in the chemistry of precipitation and surface water in a national network of small watersheds: Hydrological processes.

Barker, J.L., and Witt III, E.C., 1990 , Effects of acidic precipitation on the water quality of streams in the Laurel Hill area, Somerset County, Pennsylvania, 1983-86: U.S. Geological Survey Water-Resources Investigations Report 89-4113, 72 p.

Bencala, K.E., McKnight, D.M., and Zellweger, G.W., 1987, Evaluation of natural tracers in an acidic and metal rich stream: Water Resources Research, v. 23, no. 5, p. 827-836.

Berg, T.M., Barnes, J.H., Sevon, W.D., Skema, V.W., Wilshusen, J.P., and Yannacci, D.S., 1989, Physiographic provinces of Pennsylvania: Pennsylvania Geological Survey, 4th ser., Map 13, 1 p.

Berg, T.M., Edmunds, W.E., Geyer, A.R., and others, comps., 1980, Geologic map of Pennsylvania: Pennsylvania Geological Survey, 4th ser., Map 1, scale 1:250,000, 3 sheets.

Biesecker, J.E., and George, J.R., 1966, Stream quality in Appalachia as related to coal-mine drainage, 1965: U.S. Geological Survey Circular 526, 27 p., 1 pl.

Carson Engineers, 1974, Operation Scarlift, Stony Creek Mine Drainage Pollution Abatement Project, SL-179.

Code of Federal Regulations, 1994, Title 40, Part 434, Section 22.

Driscoll, C.T., Baker, J.P., Bisogni, J.J., Jr., and Schofield, C.L., 1980, Effect of aluminum speciation on fish in dilute acidified water: Nature, v. 284, p. 161-164.

Fishman, M.J., and Friedman, L.C., eds., 1989, Methods for determination of inorganic substances in water and fluvial sediments: U.S. Geological Survey Techniques of Water Resources Investigations, book 5, chap. A1, 545 p.

Hedin, R.S., and Narin, R.W., 1992, Designing and sizing passive mine drainage treatment systems, in Proceedings, Thirteenth annual West Virginia surface mine drainage task force symposium: Morgantown, W. Va., 11 p.

1993, Contaminant removal capabilities of wetlands constructed to treat coal mine drainage, in G.A. Moshiri, ed., Constructed wetlands for water quality improvement: Boca Raton, Fla., Lewis Publishers, p. 187-195.

Hedin, R.S., Narin, R.W., and Kleinmann, R.L.P., 1994, Passive treatment of coal mine drainage: U.S. Bureau of Mines Information Circular 9389, 35 p.

Herb, W.J., Shaw, L.C., and Brown, D.E., 1981, Hydrology of area 3, eastern coal province, Pennsylvania: U.S. Geological Survey Water-Resources Investigations Report 81-537, 88 p.

Kepler, D.A., and McCleary, E.C., 1994, Successive alkalinity-producing systems (SAPS) for the treatment of acid mine drainage: International Land Reclamation and Mine Drainage Conference and Third International Conference on the Abatement of Acidic Drainage [Proceedings], v. 1, Mine Drainage, p. 195-204. 


\section{REFERENCES CITED-Continued}

Kleinmann, R.L.P., 1989, Acid Mine Drainage: $\quad$ Engineering Mining Journal, v. 190, p. 16I-16N.

Kleinmann, R.L.P., Jones, J.R., and Erickson, P.M., 1988, An assessment of the coal mine drainage problem: 10th Annual Conference of the Association of Abandoned Mine Land Programs, Pennsylvania Bureau of Abandoned Mine Lands Reclamation \{Proceedings\}, p. 1-9.

Mills, A.L., 1985, Soil Reclamation Processes, in Klein, D., Tate, R.L., eds.: New York, Marcel Dekker, Inc., p. 35-81.

Nairn, R.W., Hedin, R.S., and Watzlaf, G.R., 1991, A preliminary review of the use of anoxic limestone drains in the passive treatment of acid mine drainage, in 12th Annual West Virginia Surface Mine Drainage Task Force Symposium: West Virginia University [Proceedings], 15 p.

Office of Surface Mining Reclamation and Enforcement, 1993, Surface mining control and reclamation act of 1977: Public law 95-87, 239 p.

Pennsylvania Coal Association, Pennsylvania Coal Data 1994, table 16.

Pennsylvania Department of Environmental Resources, 1994a, Methods manual: [Harrisburg, Pa.], Bureau of Laboratories, v. 1, [n.p.].

1994b, Commonwealth of Pennsylvania 1994 water quality assessment: Harrisburg, Pa., 186 p.

Rantz, S.E., and others, 1982, Measurement and computation of streamflow, vol. 1 and 2: U.S. Geological Survey Water-Supply Paper 2175, 631 p.

Toler, L.G., 1982, Some chemical characteristics of mine drainage in Illinois: U.S. Geological Survey Water-Supply Paper 1078, 47 p.

U.S. Army Corps of Engineers, 1993, Johnstown, Pennsylvania local flood protection project, reconnaissance report on water and sediment quality and aquatic life resources pertinent to rehabilitation of the flood reduction channel: Pittsburgh District, $67 \mathrm{p}$.

1994, Conemaugh River Basin Pennsylvania, Reconnaissance Study: Pittsburgh District, 67 p.

U.S. Department of the Interior, 1967, Stream pollution by coal mine drainage in Appalachia: Federal Water Pollution Control Administration, prepared in 1967 and revised in 1969, 261 p.

1968, Stream pollution by coal mine drainage upper Ohio River Basin: Federal Water Pollution Control Administration, p. 110.

U.S. Environmental Protection Agency, 1971, Water supply and water quality control study, Conemaugh River Basin, Pennsylvania: Wheeling Field Office.

1972, Cooperative mine drainage survey, Kiskiminetas River Basin: Wheeling Field Office, p. 251-313.

1994, Drinking water regulations and health advisories: Washington, D.C., Office of Water, 11 p.

U.S. Geological Survey, 1976-81, Water resources data for Pennsylvania, v. 3, Ohio River and St. Lawrence River Basins: U.S. Geological Survey Water-Data Reports PA 76-3 to PA 81-3 (published annually). 


\section{REFERENCES CITED-Continued}

Ward, J.R., and Harr, C.A., eds., 1990, Methods for collection and processing of surface-water and bedmaterial samples for physical and chemical analyses: U.S. Geological Survey Open-File Report 90-140, $71 \mathrm{p}$.

Witt III, E.C., 1991, Water-resources data for North Fork Bens Creek, Somerset County, Pennsylvania, August 1983 through September 1988: U.S. Geological Survey Open-File Report 89-584, 61 p. 
APPENDIXES 


\section{Appendix 1. Geographic information system (GIS) datasets}

Hydrography - Two sets of stream data were compiled for the study at 1:24,000 and 1:100,000-scales. Both have line and polygon topology. A stream layer was extracted from the Pennsylvania Department of Transportation (PennDOT) county line files using attributes for water features. This dataset was originally in the Intergraph format. The second dataset is from the Digital Line Graph (DLG) series 1:100,000-scale data from National Mapping Division (NMD). Specific infomation for the creation, accuracy, topological consistency, and attributes of these datasets can be found by contacting PennDOT and NMD.

Roads - This line dataset was extracted from the PennDOT county line files using attributes for transportation features. Specific information for the creation, accuracy, topological consistency, and attributes of this dataset can be found by contacting PennDOT.

Municipal boundaries - This dataset was created by digitizing county and township lines from paper 7.5-minute topographic quadrangles. Root Mean Square (RMS) errors were below 0.006 inches. Both line and polygon topology are present. The only attribute added to the line attribute table is CLASS and is defined as a character type with input and output size of one. CLASS is a code for distinguishing township lines from lines which are both township and county lines. Valid codes for this attribute are $C$ and $T$ which represent county and township, respectively. Attributes added to the polygon attribute table include: FIPPST, FIPPSCO, and CENSMCD. These attributes are defined as integer type with an input and output of two, three, and three, respectively. FIPPST is the state code, FIPPSCO is the couny code, and CENSMCD is the Census MCD code obtained from the Geographic Identification Code Scheme.

Drainage basin boundaries - In 1989, the Pennsylvania Department of Environmental Resources (PaDER), in cooperation with the USGS, published the Pennsylvania Gazetteer of Streams. This publication contains information related to named streams in Pennsylvania. Drainage basin boundaries are delineated on 7.5-minute series topographic paper quadrangles in Pennsylvania, a total of 878 quadrangles. These boundaries enclose catchment areas for named streams that flow through named hollows, using the hollow name, e.g., "Smith Hollow." This was done in an effort to name as many of the 64,000 streams as possible. RMS errors were below .006 inches and both line and polygon topology are present. Two attributes were added to the polygon attribute table; WRDS\# and HUC. The WRDS\# is the water resources data system number for streams from the PaDER water use database. This attribute is defined as an integer type with an input and output size of six. Valid codes are 45084-45804, which define the Stonycreek watershed. The HUC attribute is the USGS hydrologic unit code (HUC) number and is an integer type having an input and output size of eight. The valid HUC code is 05010007 . Further information about this dataset can be found by contacting the USGS in Lemoyne, Pennsylvania.

Geology - The 1980 Geologic Map of Pennsylvania, by T.M. Berg and others (1980), is the source map for this dataset. This map shows surface geology, fomational contacts, faults, and several glacial advances, and is printed at a scale of 1:250,000 in the Transverse Mercator projection. A stable-base separate of geologic formation boundaries was scanned using a drum-type scanner. Only geologic contact lines and faults between different geologic formations are delineated on this dataset with some fault lines extending into areas of identical formations. The attribute FM was added to the polygon attribute table and is defined as a character item having an input and output value of two. This attribute is a two-letter abbreviation defined by the USGS Bulletin 1200, Lexicon of Geology Names of the United States for 1936-1960. Some positional errors exist in the dataset, therefore, the positional accuracy is 508 meters, or a scale of 1:1,000,000. The Geologic Map of Pennsylvania was never made to be a digital product and although this dataset has been used by the USGS, no warranty, expressed or implied, is made by the USGS as to the accuracy and functioning of the dataset nor shall the fact of distribution constitute any such warranty, and no responsibility is assumed by the USGS in connection herewith. 
Land use/land cover - This dataset is a product of NMD and is called the Geographic Information Retrieval and Analysis System (GIRAS). This dataset has been attributed with the Anderson Level-II land use/land cover classifications for 1973-1977 and has line and polygon topology. Specific information for the creation, accuracy, topological consistency, and attributes of this dataset can be found by contacting NMD.

State game lands - This dataset was created by digitizing state game land lines from paper 7.5-minute topographic quadrangles. Root Mean Square (RMS) errors were below .006 inches. Both line and polygon topology are present. Attributes were not added to the dataset.

Special protection waters - Using the existing 1:24,000 and 1:100,000-scale hydrography layers, linear features were manually split and attributes were added to the line attribute tables. The only attribute added, QUAL, a character type with an input and output value of two, defines the stream reaches with a special protection code. Valid entries are HQ, for High Quality, and EV, for Exceptional Value. Since the linear topology has been altered, this dataset is a separate layer from the hydrography datasets. Only line topology is present.

Wetlands - This dataset was created by digitizing 7.5-minute quadrangles delineated with areas designated by the U.S. Fish and Wildlife Service (USFWS) for wetlands and combining existing 7.5-minute quadrangle datasets already digitized by USFWS into a single layer. Only eight quads were digitized by USGS: Bakerstown, Boswell, Johnstown, Ogletown, Rachelwood, Somerset, Stoystown, and Windber. RMS errors were below .006 inches. Both line and polygon topology are present. Attributes were not added to the line attribute table. Attributes added to the polygon attribute table are MAJOR1 and MINOR1, defined as integers with inputs and outputs of six for each. Valid codes and definitions are numerous and range in order, but can be obtained from the USFWS.

Mine discharges - This dataset contains information on all mine discharges sampled from April 1992 through November 1994 throughout the Stonycreek River Basin. Only point topology is present in the dataset. The point location was determined in the field using a Global Positioning System (GPS) receiver with differential correction from base station data. Attributes added to the dataset include: PRI_SCORE, PRI_RANK, and PRI_INDEX. These numeric values were determined by a program designed to prioritize the mine discharge sites for remediation based on comparative water quality data.

Surface-water-quality data - This dataset contains information on surface-water sites sampled on the mainstem of the Stonycreek River and major tributaries. Only point topology is present. The locations of the sites were determined from paper 7.5-minute topographic quadrangles. Attributes include all water quality data collected during the investigation.

Ground water site inventory (GWSI) data - The GWSI data for the Stonycreek River drainage system was retrieved from the GWSI database and imported to ARC/INFO. The dataset contains point information only, neither line nor polygon topology are present.

Pennsylvania water well inventory (PWWI) data - The PWWI data for the Stonycreek River drainage system was retrieved from the PWWI database and imported to ARC/INFO. The dataset contains point information only, neither line nor polygon topology are present.

DEM - DEM data for the project area were obtained from the NMD and clipped to the basin boundary. Specific information regarding the DEM data can be obtained by contacting NMD. 
Appendix 2. Location coordinates and station numbers for sampled mine discharges in the Stonycreek River Basin

\begin{tabular}{|c|c|c|c|c|}
\hline $\begin{array}{c}\text { Site } \\
\text { number }\end{array}$ & $\begin{array}{l}\text { USGS } \\
\text { topographic } \\
\text { quadrangle }\end{array}$ & Latitude & Longitude & $\begin{array}{l}\text { Station } \\
\text { number }\end{array}$ \\
\hline 1 & Hooversville & 400731.1 & 785504.8 & 400731078550501 \\
\hline 2 & Hooversville & 400734.6 & 785516.2 & 400735078551601 \\
\hline 3 & Stoystown & 400648.0 & 785441.9 & 400648078544201 \\
\hline 4 & Hooversville & 400749.4 & 785522.1 & 400749078552201 \\
\hline 5 & Hooversville & 400900.0 & 785425.6 & 400900078542601 \\
\hline 6 & Hooversville & 400849.0 & 785318.6 & 400849078531901 \\
\hline 7 & Hooversville & 400930.2 & 785439.4 & 400930078543901 \\
\hline 8 & Hooversville & 400927.4 & 785441.3 & 400927078544101 \\
\hline 9 & Somerset & 400105.3 & 790046.4 & 400105079004601 \\
\hline 10 & Somerset & 400121.8 & 790039.5 & 400122079004001 \\
\hline 11 & Somerset & 400124.1 & 790041.8 & 400124079004201 \\
\hline 12 & Central City & 400103.7 & 785056.0 & 400104078505601 \\
\hline 13 & Central City & 400028.9 & 785112.4 & 400029078511201 \\
\hline 14 & Central City & 400718.8 & 784824.7 & 400719078482501 \\
\hline 15 & Central City & 400702.0 & 784809.6 & 400702078481001 \\
\hline 16 & Central City & 400626.4 & 784816.3 & 400626078481601 \\
\hline 17 & Stoystown & 400159.1 & 785947.7 & 400159078594801 \\
\hline 18 & Stoystown & 400222.7 & 785928.5 & 400222078592801 \\
\hline 19 & Central City & 400648.1 & 784847.3 & 400648078484701 \\
\hline 20 & Central City & 400522.7 & 784756.4 & 400523078475601 \\
\hline 21 & Stoystown & 400416.1 & 785332.5 & 400416078533201 \\
\hline 22 & Stoystown & 400208.3 & 785927.8 & 400208078592801 \\
\hline 23 & Stoystown & 400125.9 & 785823.9 & 400126078582401 \\
\hline 24 & Stoystown & 400525.0 & 785450.8 & 400525078545101 \\
\hline 25 & Stoystown & 400412.9 & 785449.6 & 400413078545001 \\
\hline 26 & Stoystown & 400357.0 & 785337.1 & 400357078533701 \\
\hline 27 & Central City & 400308.8 & 784744.2 & 400309078474401 \\
\hline 28 & Windber & 401242.9 & 784924.5 & 401243078492401 \\
\hline 29 & Windber & 401301.9 & 784945.0 & 401302078494501 \\
\hline 30 & Windber & 401218.9 & 784924.4 & 401219078492401 \\
\hline 31 & Windber & 401221.3 & 784929.0 & 401221078492901 \\
\hline 32 & Windber & 401420.2 & 785125.5 & 401420078512601 \\
\hline 33 & Windber & 401428.8 & 785132.6 & 401429078513301 \\
\hline 34 & Stoystown & 400704.8 & 785358.2 & 400705078535801 \\
\hline 35 & Stoystown & 400718.1 & 785343.1 & 400718078534301 \\
\hline 36 & Stoystown & 400653.1 & 785530.0 & 400653078553001 \\
\hline 37 & Central City & 400714.3 & 785034.8 & 400714078503501 \\
\hline 38 & Central City & 400407.1 & 784814.6 & 400407078481501 \\
\hline 39 & Windber & 400737.0 & 785125.3 & 400737078512501 \\
\hline 40 & Windber & 400920.1 & 784914.4 & 400920078491401 \\
\hline 41 & Windber & 400944.2 & 784914.7 & 400944078491501 \\
\hline 42 & Windber & 401038.9 & 784936.6 & 401039078493701 \\
\hline 43 & Windber & 401044.4 & 785008.5 & 401044078500901 \\
\hline 44 & Windber & 401413.3 & 784824.2 & 401413078482401 \\
\hline 45 & Ogletown & 401402.5 & 784356.8 & 401402078435701 \\
\hline
\end{tabular}


Appendix 2. Location coordinates and station numbers for sampled mine discharges in the Stonycreek River Basin-Continued

\begin{tabular}{|c|c|c|c|c|}
\hline $\begin{array}{c}\text { Site } \\
\text { number }\end{array}$ & $\begin{array}{c}\text { USGS } \\
\text { topographic } \\
\text { quadrangle }\end{array}$ & Latitude & Longitude & $\begin{array}{l}\text { Station } \\
\text { number }\end{array}$ \\
\hline 46 & Ogletown & 401417.9 & 784408.0 & 401418078440801 \\
\hline 47 & Hooversville & 400906.2 & 785945.5 & 400906078594601 \\
\hline 48 & Hooversville & 400903.2 & 785926.8 & 400903078592701 \\
\hline 49 & Hooversville & 400823.5 & 785612.7 & 400824078561301 \\
\hline 50 & Hooversville & 400819.0 & 785539.9 & 400819078554001 \\
\hline 51 & Somerset & 400537.4 & 790130.9 & 400537079013101 \\
\hline 52 & Boswell & 400815.9 & 790337.7 & 400816079033801 \\
\hline 53 & Boswell & 400820.9 & 790332.5 & 400821079033301 \\
\hline 54 & Boswell & 400733.3 & 790646.5 & 400733079064601 \\
\hline 55 & Berlin & 395750.9 & 785240.1 & 395751078524001 \\
\hline 56 & Berlin & 395751.7 & 785238.0 & 395752078523801 \\
\hline 57 & Berlin & 395745.3 & 785242.9 & 395745078524301 \\
\hline 58 & New Baltimore & 395817.3 & 785217.2 & 395817078521701 \\
\hline 59 & Stoystown & 400528.5 & 785450.4 & 400528078545001 \\
\hline 60 & Stoystown & 400532.0 & 785449.4 & 400532078544901 \\
\hline 61 & Stoystown & 400059.8 & 785524.8 & 400100078552501 \\
\hline 62 & Stoystown & 400029.6 & 785624.0 & 400030078562401 \\
\hline 63 & Stoystown & 400019.8 & 785604.8 & 400020078560501 \\
\hline 64 & Stoystown & 400118.8 & 785512.3 & 400119078551201 \\
\hline 65 & Stoystown & 400130.0 & 785451.4 & 400130078545101 \\
\hline 66 & Stoystown & 400122.7 & 785502.5 & 400123078550201 \\
\hline 67 & Stoystown & 400553.4 & 785634.2 & 400553078563401 \\
\hline 68 & Stoystown & 400540.2 & 785554.2 & 400540078555401 \\
\hline 69 & Stoystown & 400500.2 & 785555.2 & 400500078555501 \\
\hline 70 & Stoystown & 400451.9 & 785557.6 & 400452078555801 \\
\hline 71 & Stoystown & 400452.6 & 785432.3 & 400453078543201 \\
\hline 72 & Stoystown & 400452.8 & 785434.3 & 400453078543401 \\
\hline 73 & Stoystown & 400508.0 & 785445.3 & 400508078544501 \\
\hline 74 & Stoystown & 400405.7 & 785449.4 & 400406078544901 \\
\hline 75 & Central City & 401428.8 & 785049.6 & 401429078504901 \\
\hline 76 & Central City & 400706.1 & 785038.1 & 400706078503801 \\
\hline 77 & Windber & 401238.2 & 784844.0 & 401238078484401 \\
\hline 78 & Windber & 401423.1 & 785114.8 & 401423078511501 \\
\hline 79 & Geistown & 401507.3 & 785000.9 & 401507078500101 \\
\hline 80 & Windber & 401502.5 & 785154.2 & 401503078515401 \\
\hline 81 & Windber & 401428.8 & 785049.6 & 401429078505001 \\
\hline 82 & Central City & 400249.6 & 784957.6 & 400250078495801 \\
\hline 83 & Central City & 400116.9 & 785214.6 & 400117078521501 \\
\hline 84 & Central City & 400236.1 & 785027.2 & 400236078502701 \\
\hline 85 & Windber & 400733.7 & 785124.0 & 400734078512401 \\
\hline 86 & Windber & 400752.0 & 784900.0 & 400752078490001 \\
\hline 87 & Stoystown & 400707.8 & 785402.7 & 400708078540301 \\
\hline 88 & Hooversville & 400914.2 & 785525.6 & 400914078552601 \\
\hline 89 & Hooversville & 400916.8 & 785529.1 & 400917078552901 \\
\hline 90 & Hooversville & 400918.0 & 785539.0 & 400918078553901 \\
\hline
\end{tabular}


Appendix 2. Location coordinates and station numbers for sampled mine discharges in the Stonycreek River Basin-Continued

\begin{tabular}{|c|c|c|c|c|}
\hline $\begin{array}{c}\text { Site } \\
\text { number }\end{array}$ & $\begin{array}{l}\text { USGS } \\
\text { topographic } \\
\text { quadrangle }\end{array}$ & Latitude & Longitude & $\begin{array}{l}\text { Station } \\
\text { number }\end{array}$ \\
\hline 91 & Hooversville & 401218.5 & 785553.3 & 401219078555301 \\
\hline 92 & Hooversville & 400939.3 & 785845.7 & 400939078584601 \\
\hline 93 & Hooversville & 400900.0 & 785419.7 & 400900078542001 \\
\hline 94 & Hooversville & 400746.9 & 785520.7 & 400747078552101 \\
\hline 95 & Hooversville & 401311.6 & 785332.9 & 401312078533301 \\
\hline 96 & Windber & 401408.2 & 785022.9 & 401408078502301 \\
\hline 97 & Hooversville & 401335.8 & 785422.3 & 401336078542201 \\
\hline 98 & Central City & 400248.1 & 785005.5 & 400248078500501 \\
\hline 99 & Central City & 400245.8 & 785007.9 & 400246078500801 \\
\hline 100 & Windber & 401417.6 & 784849.8 & 401418078485001 \\
\hline 101 & Windber & 401415.1 & 784849.9 & 401415078485001 \\
\hline 102 & Windber & 401400.4 & 784735.6 & 401400078473601 \\
\hline 103 & Windber & 401356.1 & 784741.2 & 401356078474101 \\
\hline 104 & Windber & 401351.5 & 784749.7 & 401352078475001 \\
\hline 105 & Stoystown & 400124.3 & 785514.1 & 400124078551401 \\
\hline 106 & Central City & 400323.0 & 785202.8 & 400323078520301 \\
\hline 107 & Johnstown & 401847.6 & 785344.3 & 401848078534401 \\
\hline 108 & Johnstown & 401846.2 & 785348.2 & 401846078534801 \\
\hline 109 & Johnstown & 401844.0 & 785257.4 & 401844078525701 \\
\hline 110 & Geistown & 401848.2 & 785224.5 & 401848078522401 \\
\hline 111 & Windber & 401359.4 & 784646.5 & 401359078464601 \\
\hline 112 & Windber & 401403.3 & 784647.6 & 401403078464801 \\
\hline 113 & Windber & 401401.9 & 784643.0 & 401402078464301 \\
\hline 114 & Windber & 401409.2 & 784648.1 & 401409078464801 \\
\hline 115 & Windber & 401408.6 & 784638.3 & 401409078463801 \\
\hline 116 & Windber & 401414.7 & 784641.5 & 401415078464101 \\
\hline 117 & Beaverdale & 401516.5 & 784414.6 & 401516078441501 \\
\hline 118 & Beaverdale & 401517.6 & 784413.6 & 401518078441401 \\
\hline 119 & Hooversville & 400857.4 & 785403.2 & 400857078540301 \\
\hline 120 & Hooversville & 400859.7 & 785414.1 & 400900078541401 \\
\hline 121 & Hooversville & 400855.2 & 785340.4 & 400855078534001 \\
\hline 122 & Hooversville & 400856.3 & 785344.8 & 400856078534501 \\
\hline 123 & Hooversville & 400850.6 & 785242.5 & 400851078524201 \\
\hline 124 & Windber & 401449.0 & 784615.4 & 401449078461501 \\
\hline 125 & Windber & 401449.7 & 784613.5 & 401450078461301 \\
\hline 126 & Windber & 401451.4 & 784612.5 & 401451078461201 \\
\hline 127 & Windber & 401500.0 & 784552.0 & 401500078455201 \\
\hline 128 & Stoystown & 400521.0 & 785613.2 & 400521078561301 \\
\hline 129 & Stoystown & 400519.6 & 785614.1 & 400520078561401 \\
\hline 130 & Johnstown & 401527.7 & 785248.5 & 401528078524801 \\
\hline 131 & Johnstown & 401532.8 & 785242.3 & 401533078524201 \\
\hline 132 & Stoystown & 400512.0 & 785620.2 & 400512078562001 \\
\hline 133 & Stoystown & 400517.9 & 785621.4 & 400518078562101 \\
\hline 134 & Stoystown & 400522.8 & 785625.1 & 400523078562501 \\
\hline 135 & Stoystown & 400520.6 & 785759.5 & 400521078575901 \\
\hline
\end{tabular}


Appendix 2. Location coordinates and station numbers for sampled mine discharges in the Stonycreek River Basin-Continued

\begin{tabular}{|c|c|c|c|c|}
\hline $\begin{array}{c}\text { Site } \\
\text { number }\end{array}$ & $\begin{array}{c}\text { USGS } \\
\text { topographic } \\
\text { quadrangle }\end{array}$ & Latitude & Longitude & $\begin{array}{l}\text { Station } \\
\text { number }\end{array}$ \\
\hline 136 & Hooversville & 400828.0 & 785536.7 & 400828078553701 \\
\hline 137 & Hooversville & 400841.9 & 785449.5 & 400842078545001 \\
\hline 138 & Geistown & 401502.3 & 784540.6 & 401502078454101 \\
\hline 139 & Geistown & 401503.1 & 784539.9 & 401503078454001 \\
\hline 140 & Geistown & 401504.7 & 784538.1 & 401505078453801 \\
\hline 141 & Geistown & 401458.1 & 784520.5 & 401458078452001 \\
\hline 142 & Geistown & 401500.0 & 784521.9 & 401500078452201 \\
\hline 143 & New Baltimore & 395906.6 & 785228.4 & 395907078522801 \\
\hline 144 & Stoystown & 395953.3 & 785236.5 & 395953078523601 \\
\hline 145 & Central City & 400120.1 & 785158.6 & 400120078515901 \\
\hline 146 & Stoystown & 400552.5 & 785632.3 & 400552078563201 \\
\hline 147 & Johnstown & 401947.7 & 785533.0 & 401948078553301 \\
\hline 148 & Johnstown & 401932.7 & 785534.2 & 401933078553401 \\
\hline 149 & Johnstown & 401941.9 & 785534.1 & 401942078553401 \\
\hline 150 & Johnstown & 401840.9 & 785459.2 & 401841078545901 \\
\hline 151 & Stoystown & 400521.3 & 785757.6 & 400521078575801 \\
\hline 152 & Stoystown & 400533.4 & 785712.4 & 400533078571201 \\
\hline 153 & Stoystown & 400534.4 & 785709.2 & 400534078570901 \\
\hline 154 & Stoystown & 400524.1 & 785622.7 & 400524078562301 \\
\hline 155 & Stoystown & 400532.4 & 785557.3 & 400532078555701 \\
\hline 156 & Stoystown & 400541.4 & 785556.6 & 400541078555701 \\
\hline 157 & Stoystown & 400548.3 & 785555.2 & 400548078555501 \\
\hline 158 & Stoystown & 400530.2 & 785450.6 & 400530078545101 \\
\hline 159 & Stoystown & 400510.6 & 785447.5 & 400511078544801 \\
\hline 160 & Stoystown & 400603.3 & 785613.4 & 400603078561301 \\
\hline 161 & Stoystown & 400620.4 & 785546.0 & 400620078554601 \\
\hline 162 & Stoystown & 400627.5 & 785530.3 & 400627078553001 \\
\hline 163 & Stoystown & 400626.0 & 785537.8 & 400626078553801 \\
\hline 164 & Hooversville & 400835.3 & 785525.8 & 400835078552601 \\
\hline 165 & Johnstown & 401627.9 & 785412.3 & 401628078541201 \\
\hline 166 & Hooversville & 401328.4 & 785914.3 & 401328078591401 \\
\hline 167 & Berlin & 395752.4 & 785236.2 & 395752078523601 \\
\hline 168 & New Baltimore & 395821.3 & 785218.4 & 395821078521801 \\
\hline 169 & New Baltimore & 395920.4 & 785139.8 & 395920078514001 \\
\hline 170 & Berlin & 395950.8 & 785241.3 & 395951078524101 \\
\hline 171 & Boswell & 400802.0 & 790104.9 & 400802079010501 \\
\hline 172 & Boswell & 400833.2 & 790044.9 & 400833079004501 \\
\hline 173 & Boswell & 400947.3 & 790215.7 & 400947079021601 \\
\hline 174 & Boswell & 401026.3 & 790102.8 & 401026079010301 \\
\hline 175 & Boswell & 401013.0 & 790046.1 & 401013079004601 \\
\hline 176 & Boswell & 400840.2 & 790246.2 & 400840079024601 \\
\hline 177 & Hooversville & 401319.1 & 785926.9 & 401319078592601 \\
\hline 178 & Hooversville & 401321.4 & 785924.1 & 401321078592401 \\
\hline 179 & Hooversville & 401330.9 & 785915.7 & 401331078591601 \\
\hline 180 & Hooversville & 401320.0 & 785959.0 & 401320078595901 \\
\hline
\end{tabular}


Appendix 2. Location coordinates and station numbers for sampled mine discharges in the Stonycreek River Basin-Continued

\begin{tabular}{|c|c|c|c|c|}
\hline $\begin{array}{c}\text { Site } \\
\text { number }\end{array}$ & $\begin{array}{l}\text { USGS } \\
\text { topographic } \\
\text { quadrangle }\end{array}$ & Latitude & Longitude & $\begin{array}{l}\text { Station } \\
\text { number }\end{array}$ \\
\hline 181 & Hooversville & 401450.9 & 785331.3 & 401451078533101 \\
\hline 182 & Ligonier & 400731.3 & 790746.0 & 400731079074601 \\
\hline 183 & Ligonier & 400731.3 & 790746.0 & 4007310790744602 \\
\hline 184 & Windber & 401443.9 & 785132.0 & 401444078513201 \\
\hline 185 & Windber & 401442.4 & 785134.9 & 401442078513501 \\
\hline 186 & Johnstown & 401839.3 & 785459.2 & 401839078545901 \\
\hline 187 & Windber & 401500.0 & 784637.7 & 401500078463801 \\
\hline 188 & Windber & 401441.6 & 784617.7 & 401442078461801 \\
\hline 189 & Johnstown & 401807.1 & 785426.9 & 401807078542701 \\
\hline 190 & Johnstown & 401729.0 & 785454.1 & 401729078545401 \\
\hline 191 & Johnstown & 401718.6 & 785436.7 & 401719078543701 \\
\hline 192 & Johnstown & 401717.8 & 785436.5 & 401718078543601 \\
\hline 193 & Johnstown & 401712.3 & 785434.2 & 401712078543401 \\
\hline 194 & Johnstown & 401711.0 & 785434.0 & 401711078543401 \\
\hline 195 & Johnstown & 401710.0 & 785434.0 & 401710078543401 \\
\hline 196 & Johnstown & 401709.0 & 785433.8 & 401709078543401 \\
\hline 197 & Johnstown & 401704.9 & 785434.5 & 401705078543401 \\
\hline 198 & Johnstown & 401810.5 & 785519.8 & 401810078552001 \\
\hline 199 & Johnstown & 401741.9 & 785510.3 & 401742078551001 \\
\hline 200 & Windber & 400817.2 & 784957.7 & 400817078495801 \\
\hline 201 & Windber & 400825.9 & 784927.4 & 400826078492701 \\
\hline 202 & Central City & 400130.5 & 785151.1 & 400130078515101 \\
\hline 203 & Central City & 400145.2 & 785021.9 & 400145078502201 \\
\hline 204 & Hooversville & 401244.7 & 785434.0 & 401245078543401 \\
\hline 205 & Hooversville & 401239.5 & 785512.1 & 401240078551201 \\
\hline 206 & Hooversville & 401229.2 & 785451.0 & 401229078545101 \\
\hline 207 & Hooversville & 401228.5 & 785454.8 & 401229078545501 \\
\hline 208 & Hooversville & 400524.7 & 790451.4 & 400525079045101 \\
\hline 209 & Somerset & 400644.4 & 790427.3 & 400644079042701 \\
\hline 210 & Stoystown & 400231.1 & 785911.6 & 400231078591201 \\
\hline 211 & Berlin & 395912.4 & 785707.8 & 395912078570801 \\
\hline 212 & New Baltimore & 395901.0 & 785230.9 & 395901078523101 \\
\hline 213 & Central City & 400032.6 & 785117.7 & 400033078511801 \\
\hline 214 & Windber & 400815.9 & 784831.6 & 400816078483201 \\
\hline 215 & Windber & 400826.1 & 784834.8 & 400826078483501 \\
\hline 216 & Windber & 400942.7 & 784931.9 & 400943078493201 \\
\hline 217 & Windber & 401332.4 & 784939.6 & 401332078494001 \\
\hline 218 & Windber & 401406.0 & 785019.0 & 401406078501901 \\
\hline 219 & Ogletown & 401331.6 & 784428.9 & 401332078442901 \\
\hline 220 & Windber & 401249.4 & 784757.0 & 401249078475701 \\
\hline 221 & Windber & 401031.2 & 785222.0 & 401031078522201 \\
\hline 222 & Windber & 401100.2 & 785151.2 & 401100078515101 \\
\hline 223 & Somerset & 400044.0 & 790035.1 & 400044079003501 \\
\hline 224 & Stoystown & 400011.3 & 785525.8 & 400011078552601 \\
\hline 225 & Stoystown & 400121.9 & 785516.6 & 400122078551701 \\
\hline
\end{tabular}


Appendix 2. Location coordinates and station numbers for sampled mine discharges in the Stonycreek River Basin-Continued

\begin{tabular}{|c|c|c|c|c|}
\hline $\begin{array}{c}\text { Site } \\
\text { number }\end{array}$ & $\begin{array}{l}\text { USGS } \\
\text { topographic } \\
\text { quadrangle }\end{array}$ & Latitude & Longitude & $\begin{array}{l}\text { Station } \\
\text { number }\end{array}$ \\
\hline 226 & Stoystown & 400559.5 & 785539.3 & 400600078553901 \\
\hline 227 & Stoystown & 400642.2 & 785444.7 & 400642078544501 \\
\hline 228 & Hooversville & 400901.0 & 785416.3 & 400901078541601 \\
\hline 229 & Windber & 401058.1 & 785204.6 & 401058078520501 \\
\hline 230 & Windber & 401054.9 & 785208.9 & 401055078520901 \\
\hline 231 & Windber & 401044.8 & 784906.4 & 401045078490601 \\
\hline 232 & Windber & 401053.7 & 784935.6 & 401054078493601 \\
\hline 233 & Windber & 401056.9 & 784935.2 & 401057078493501 \\
\hline 234 & Windber & 401043.0 & 784937.0 & 401043078493701 \\
\hline 235 & Windber & 401040.8 & 784938.3 & 401041078493801 \\
\hline 236 & Windber & 401245.2 & 785140.1 & 401245078514001 \\
\hline 237 & Windber & 401246.5 & 785139.8 & 401246078514001 \\
\hline 238 & Windber & 401248.7 & 785135.9 & 401249078513601 \\
\hline 239 & Windber & 401243.9 & 785147.9 & 401244078514801 \\
\hline 240 & Windber & 401237.5 & 785147.1 & 401237078514701 \\
\hline 241 & Hooversville & 401104.0 & 785425.8 & 401104078542601 \\
\hline 242 & Hooversville & 400739.7 & 785522.2 & 400740078552201 \\
\hline 243 & Hooversville & 401146.8 & 785306.7 & 401147078530701 \\
\hline 244 & Hooversville & 401153.6 & 785252.0 & 401154078525201 \\
\hline 245 & Hooversville & 401203.7 & 785228.5 & 401204078522801 \\
\hline 246 & Windber & 401206.6 & 785224.7 & 401207078522501 \\
\hline 247 & Windber & 401213.0 & 785219.0 & 401213078521901 \\
\hline 248 & Johnstown & 401906.8 & 785450.5 & 401907078545001 \\
\hline 249 & Hooversville & 400944.1 & 785450.1 & 400944078545001 \\
\hline 250 & Hooversville & 400941.2 & 785446.7 & 400941078544701 \\
\hline 251 & Hooversville & 400940.9 & 785446.5 & 400941078544601 \\
\hline 252 & Hooversville & 400931.1 & 785448.1 & 400931078544801 \\
\hline 253 & Hooversville & 401054.2 & 785424.7 & 401054078542501 \\
\hline 254 & Hooversville & 401039.8 & 785423.3 & 401040078542301 \\
\hline 255 & Hooversville & 401052.3 & 785436.6 & 401052078543701 \\
\hline 256 & Somerset & 400651.0 & 790413.0 & 400651079041301 \\
\hline 257 & Somerset & 400707.5 & 790410.4 & 400708079041001 \\
\hline 258 & Somerset & 400706.2 & 790318.4 & 400706079031801 \\
\hline 259 & Hooversville & 400838.7 & 785908.1 & 400839078590801 \\
\hline 260 & Hooversville & 401122.7 & 785446.3 & 401123078544601 \\
\hline 261 & Stoystown & 400609.6 & 785554.4 & 400610078555401 \\
\hline 262 & Stoystown & 400113.0 & 785507.5 & 400113078550801 \\
\hline 263 & Stoystown & 400419.9 & 785341.4 & 400420078534101 \\
\hline 264 & Stoystown & 400547.9 & 785554.6 & 400548078555401 \\
\hline 265 & Central City & 400709.9 & 784828.3 & 400710078482801 \\
\hline 266 & Central City & 400715.0 & 784828.3 & 400715078482801 \\
\hline 267 & Windber & 400742.4 & 785026.5 & 400742078502601 \\
\hline 268 & Geistown & 401507.1 & 785038.4 & 401507078503801 \\
\hline 269 & Hooversville & 401238.1 & 785424.2 & 401238078542401 \\
\hline 270 & Hooversville & 401231.2 & 785519.8 & 401231078552001 \\
\hline
\end{tabular}




\section{Appendix 3. Field data and laboratory analyses of mine discharges}

[ $\mathrm{ft}^{3} / \mathrm{s}$, cubic foot per second; gal $/ \mathrm{min}$, gallon per minute; ${ }^{\circ} \mathrm{C}$, degrees Celsius; $\mu \mathrm{S} / \mathrm{cm}$, microsiemen per centimeter at 25 degrees Celsius; mg/L, milligram per liter; <, less than; --, no data available]

\begin{tabular}{|c|c|c|c|c|c|c|c|c|c|c|c|}
\hline $\begin{array}{c}\text { Site } \\
\text { number }\end{array}$ & $\begin{array}{c}\text { Local } \\
\text { identifier } \\
\text { (Topographic } \\
\text { quadrangle) }\end{array}$ & Date & Time & $\begin{array}{l}\text { Discharge, } \\
\text { instan- } \\
\text { taneous } \\
\left(\mathrm{ft}^{3} / \mathrm{s}\right)\end{array}$ & $\begin{array}{l}\text { Flow rate, } \\
\text { instan- } \\
\text { taneous } \\
\text { (gal/min) }\end{array}$ & $\begin{array}{l}\text { Temper- } \\
\text { ature, } \\
\text { water } \\
\left({ }^{\circ} \mathrm{C}\right)\end{array}$ & $\begin{array}{c}\text { Specific } \\
\text { conduc- } \\
\text { tance } \\
(\mu \mathrm{S} / \mathrm{cm})\end{array}$ & $\begin{array}{l}\mathrm{pH} \text {, water } \\
\text { whole } \\
\text { field } \\
\text { (standard } \\
\text { units) }\end{array}$ & $\begin{array}{c}\text { Alkalinity, } \\
\text { water } \\
(\mathrm{mg} / \mathrm{L} \text { as } \\
\mathrm{CaCO}_{3} \text { ) }\end{array}$ & $\begin{array}{c}\text { Residue at } \\
105^{\circ} \mathrm{C} \\
\text { dissolved } \\
\text { (mg/L) }\end{array}$ & $\begin{array}{c}\text { Carbon, } \\
\text { inorganic, } \\
\text { total } \\
\text { (mg/L } \\
\text { as C) }\end{array}$ \\
\hline \multirow[t]{2}{*}{1} & Hooversville & $06-17-92$ & 0845 & .04 & 16 & 11.0 & 2,580 & 2.8 & 0 & 2,360 & 1.3 \\
\hline & & 08-18-93 & 1405 & .01 & 3.3 & 21.5 & 2,240 & 3.4 & 0 & 2,180 & 1.0 \\
\hline 2 & Hooversville & $06-17-92$ & 1030 & .02 & 9.0 & 14.5 & 1,680 & 3.1 & 0 & 1,390 & $<1.0$ \\
\hline \multirow[t]{2}{*}{3} & Stoystown & $06-17-92$ & 1130 & .35 & 155 & 11.0 & 2,570 & 2.8 & 0 & 2,890 & $<1.0$ \\
\hline & & $08-18-93$ & 1135 & .23 & 105 & 11.0 & 2,580 & 3.4 & 0 & 3,160 & 16 \\
\hline \multirow{4}{*}{4} & & $04-21-94$ & 1100 & 1.1 & 501 & 10.5 & 2,220 & 2.7 & 0 & 2,360 & 16 \\
\hline & Hooversville & 06-17-92 & 1330 & .78 & 348 & 11.5 & 1,750 & 2.8 & 0 & 1,540 & $<1.0$ \\
\hline & & 08-18-93 & 1340 & .20 & 90 & 12.0 & 1,800 & 3.3 & 0 & 1,740 & 7.0 \\
\hline & & 05-09-94 & 1520 & .95 & 429 & 11.5 & 1,310 & 2.7 & 0 & 1,140 & 13 \\
\hline 5 & Hooversville & $06-17-92$ & 1430 & .76 & 341 & 9.5 & 708 & 4.5 & 4 & 602 & 1.0 \\
\hline \multirow[t]{3}{*}{6} & Hooversville & $06-17-92$ & 1530 & .68 & 306 & 11.0 & 1,040 & 4.4 & 5 & 1,000 & $<1.0$ \\
\hline & & 08-19-93 & 1325 & .23 & 105 & 11.0 & 1,020 & 5.0 & 40 & 930 & 30 \\
\hline & & 05-09-94 & 1415 & 1.7 & 756 & 11.0 & 853 & 5.1 & 22 & 918 & 30 \\
\hline \multirow[t]{3}{*}{7} & Hooversville & 06-17-92 & 1620 & .20 & 91 & 10.5 & 1,170 & 3.0 & 0 & 1,090 & $<1.0$ \\
\hline & & 09-01-93 & 1310 & .15 & 67 & 10.5 & 1,820 & 2.8 & 0 & 1,980 & 17 \\
\hline & & 05-09-94 & 1330 & .69 & 312 & 10.0 & 866 & 2.9 & 0 & 798 & 19 \\
\hline 8 & Hooversville & 06-17-92 & 1700 & .01 & 5.8 & 16.5 & 2,290 & 2.8 & 0 & 2,640 & $<1.0$ \\
\hline 9 & Somerset & 06-18-92 & 0730 & .02 & 6.7 & 10.5 & 836 & 6.1 & 62 & 688 & 2.8 \\
\hline 10 & Somerset & 06-18-92 & 0815 & .27 & 122 & 10.0 & 805 & 3.5 & 0 & 628 & 1.0 \\
\hline 11 & Somerset & $06-18-92$ & 0845 & .30 & 136 & 10.5 & 710 & 4.4 & 2 & 628 & 1.1 \\
\hline 12 & Central City & 06-24-92 & 1400 & .19 & 86 & 15.0 & 2,750 & 6.4 & 130 & 3,020 & 37 \\
\hline 13 & Central City & 06-24-92 & 1515 & .12 & 52 & 10.5 & 1,970 & 6.0 & 30 & 1,890 & 8.2 \\
\hline \multirow[t]{6}{*}{14} & Central City & 06-24-92 & 1645 & 1.8 & 799 & 10.0 & 1,110 & 3.6 & 0 & 980 & 8.3 \\
\hline & & $10-06-92$ & 1635 & 1.5 & 678 & 10.5 & 1,160 & 3.6 & 0 & 948 & 5.5 \\
\hline & & $10-06-92$ & 1140 & 1.5 & 678 & 10.5 & 1,160 & 3.7 & 0 & 960 & 4.7 \\
\hline & & $10-07-92$ & 0615 & 1.5 & 678 & 9.0 & 1,180 & 3.5 & 0 & 958 & 5.2 \\
\hline & & 08-18-93 & 1530 & 1.3 & 584 & 10.5 & 1,170 & 3.6 & 0 & 1,190 & 41 \\
\hline & & 05-03-94 & 1215 & 5.1 & 2,300 & 10.0 & 880 & 3.5 & 0 & 792 & 29 \\
\hline \multirow[t]{6}{*}{15} & Central City & 06-24-92 & 1745 & .21 & 96 & 10.5 & 1,410 & 3.6 & 0 & 1,290 & 10 \\
\hline & & $10-06-92$ & 0945 & .12 & 56 & 9.5 & 1,380 & 3.5 & 0 & 1,120 & 15 \\
\hline & & $10-06-92$ & 1545 & .12 & 56 & 10.5 & 1,390 & 3.2 & 0 & 1,080 & 3.7 \\
\hline & & $10-07-92$ & 0555 & .12 & 56 & 9.0 & 1,410 & 3.2 & 0 & 1,090 & 12 \\
\hline & & 08-18-93 & 1610 & .11 & 47 & 11.0 & 1,380 & 3.4 & 0 & 1,620 & 57 \\
\hline & & 05-03-94 & 1120 & .27 & 120 & 10.0 & 853 & 3.0 & 0 & 684 & 37 \\
\hline \multirow[t]{3}{*}{16} & Central City & $06-24-92$ & 1840 & 5.0 & 2,250 & 11.0 & 1,600 & 3.3 & 0 & 1,540 & 4.1 \\
\hline & & 08-18-93 & 1710 & 3.4 & 1,510 & 11.0 & 1,780 & 3.1 & 0 & 1,850 & 27 \\
\hline & & 05-03-94 & 1040 & 8.3 & 3,750 & 10.5 & 1,760 & 2.9 & 0 & 1,630 & 23 \\
\hline \multirow[t]{4}{*}{17} & Stoystown & 06-25-92 & 0840 & .63 & 284 & 9.5 & 728 & 3.3 & 0 & 544 & 2.5 \\
\hline & & 09-09-93 & 0920 & .33 & 146 & 10.5 & 780 & 3.4 & 0 & 606 & $<1.0$ \\
\hline & & $08-31-93$ & 0840 & .34 & 151 & 9.5 & 774 & 3.3 & 0 & 596 & 11 \\
\hline & & 05-12-94 & 1125 & 2.5 & 1,120 & 9.0 & 438 & 3.6 & 0 & 302 & 6.9 \\
\hline 18 & Stoystown & $06-25-92$ & 0930 & .02 & 11 & 9.5 & 515 & 6.4 & 46 & 404 & 12 \\
\hline \multirow[t]{3}{*}{19} & Central City & $06-29-92$ & 1100 & 4.0 & 1,780 & 10.0 & 900 & 5.1 & 14 & 808 & 21 \\
\hline & & $10-06-92$ & 1800 & 4.5 & 2,000 & 9.5 & 840 & 5.0 & 10 & 670 & 16 \\
\hline & & 10-07-92 & 0655 & 4.5 & 2,000 & 9.0 & 850 & 5.1 & 11 & 662 & 14 \\
\hline
\end{tabular}




\section{Appendix 3. Field data and laboratory analyses of mine discharges-Continued}

$\left[\mathrm{ft}^{3} / \mathrm{s}\right.$, cubic foot per second; gal $/ \mathrm{min}$, gallon per minute; ${ }^{\circ} \mathrm{C}$, degrees Celsius; $\mu \mathrm{S} / \mathrm{cm}$, microsiemen per centimeter at 25 degrees Celsius; mg/L, milligram per liter; <, less than; --, no data available]

\begin{tabular}{|c|c|c|c|c|c|c|c|c|c|c|c|}
\hline Date & $\begin{array}{l}\text { Sulfate, } \\
\text { dissolved } \\
(\mathrm{mg} / \mathrm{L} \\
\left.\text { as } \mathrm{SO}_{4}\right)\end{array}$ & $\begin{array}{c}\text { Fluoride, } \\
\text { total } \\
\text { (mg/L as F) }\end{array}$ & $\begin{array}{c}\text { Iron, total } \\
\text { recoverable } \\
(\mu \mathrm{g} / \mathrm{L} \\
\text { as Fe }\end{array}$ & $\begin{array}{c}\text { Iron, } \\
\text { dissolved } \\
(\mu \mathrm{g} / \mathrm{L} \\
\text { as Fe }\end{array}$ & $\begin{array}{c}\text { Iron, } \\
\text { ferrous, } \\
\text { dissolved } \\
(\mu \mathrm{g} / \mathrm{L} \\
\text { as Fe }\end{array}$ & $\begin{array}{c}\text { Manganese, } \\
\text { total } \\
\text { recoverable } \\
(\mu \mathrm{g} / \mathrm{L} \\
\text { as Mn }\end{array}$ & $\begin{array}{c}\text { Manganese, } \\
\text { dissolved } \\
(\mu \mathrm{g} / \mathrm{L} \\
\text { as } \mathrm{Mn})\end{array}$ & $\begin{array}{c}\text { Aluminum, } \\
\text { total } \\
\text { recoverable } \\
(\mu \mathrm{g} / \mathrm{L} \\
\text { as Al) }\end{array}$ & $\begin{array}{l}\text { Aluminum, } \\
\text { dissolved } \\
(\mu \mathrm{g} / \mathrm{L} \\
\text { as Al) }\end{array}$ & $\begin{array}{c}\text { Acidity, } \\
\text { total } \\
\text { heated } \\
(\mathrm{mg} / \mathrm{L} \text { as } \\
\left.\mathrm{CaCO}_{3}\right)\end{array}$ & $\begin{array}{c}\text { Acidity, } \\
\text { mineral } \\
\text { (methyl } \\
\text { orange) } \\
(\mathrm{mg} / \mathrm{L} \text { as } \\
\left.\mathrm{CaCO}_{3}\right)\end{array}$ \\
\hline $06-17-92$ & 1,500 & 1.1 & 46,000 & 39,000 & -- & 30,000 & 25,000 & 38,000 & 32,000 & 380 & 130 \\
\hline $08-18-93$ & 1,400 & .7 & 10,000 & 10,000 & 680 & 20,000 & 20,000 & 22,000 & 22,000 & 272 & 126 \\
\hline $06-17-92$ & 990 & .4 & 3,800 & 3,600 & -- & 8,800 & 8,800 & 5,200 & 5,200 & 92 & 42 \\
\hline $06-17-92$ & 1,600 & 1.4 & 75,000 & 75,000 & -- & 23,000 & 23,000 & 55,000 & 54,000 & 630 & 280 \\
\hline $08-18-93$ & 1,400 & 1 & 98,000 & 97,000 & 7,500 & 23,000 & 23,000 & 56,000 & 56,000 & 742 & 306 \\
\hline $04-21-94$ & 1,700 & .9 & 64,000 & 64,000 & 2,900 & 21,000 & 21,000 & 48,000 & 48,000 & 524 & 222 \\
\hline $06-17-92$ & 960 & .8 & 30,000 & 30,000 & -- & 5,200 & 5,200 & 20,000 & 20,000 & 270 & 140 \\
\hline $08-18-93$ & 1,200 & .8 & 23,000 & 23,000 & 1,000 & 3,900 & 3,800 & 22,000 & 22,000 & 258 & 114 \\
\hline 05-09-94 & 880 & .6 & 19,000 & 18,000 & 330 & 3,000 & 3,000 & 14,000 & 14,000 & 204 & 84 \\
\hline $06-17-92$ & 390 & .2 & 40 & 30 & -- & 2,600 & 2,600 & 800 & 800 & 9.4 & 0 \\
\hline $06-17-92$ & 630 & .7 & 9,900 & 70 & -- & 3,500 & 3,200 & 9,500 & 6,100 & 34 & 0 \\
\hline 08-19-93 & 640 & .6 & 6,000 & 500 & -- & 2,900 & 2,800 & 7,100 & 4,300 & 26 & -- \\
\hline 05-09-94 & 540 & .5 & 3,200 & 51 & 170 & 4,100 & 4,100 & 4,900 & 1,000 & 17 & -- \\
\hline $06-17-92$ & 660 & .7 & 11,000 & 11,000 & -- & 2,400 & 2,400 & 20,000 & 20,000 & 180 & 58 \\
\hline 09-01-93 & 1,300 & 1.0 & 26,000 & 26,000 & 840 & 4,400 & 4,400 & 43,000 & 42,000 & 364 & 104 \\
\hline 05-09-94 & 610 & .6 & 6,600 & 6,200 & 320 & 1,600 & 1,600 & 13,000 & 12,000 & 138 & 34 \\
\hline $06-17-92$ & 1,500 & 2.2 & 62,000 & 62,000 & -- & 8,200 & 8,200 & 62,000 & 62,000 & 560 & 210 \\
\hline $06-18-92$ & 380 & $<.2$ & 38,000 & 38,000 & -- & 2,600 & 2,600 & 280 & 170 & 0 & 0 \\
\hline $06-18-92$ & 390 & .2 & 750 & 700 & -- & 91,000 & 900 & 2,000 & 1,900 & 24 & 5 \\
\hline $06-18-92$ & 360 & $<.2$ & 5,800 & 5,000 & -- & 1,600 & 1,400 & 1,000 & 800 & 20 & 0 \\
\hline $06-24-92$ & 1,700 & $<.2$ & 13,000 & 5,400 & -- & 17,000 & 17,000 & 250 & 200 & 0 & 0 \\
\hline $06-24-92$ & 1,200 & .3 & 8,300 & 4,800 & -- & 2,900 & 2,800 & 1,500 & 400 & 0 & 0 \\
\hline $06-24-92$ & 730 & .3 & 880 & 800 & -- & 6,700 & 6,500 & 10,000 & 9,700 & 88 & 7 \\
\hline $10-06-92$ & 680 & .4 & 2,100 & 1,800 & -- & 7,200 & 7,100 & 12,000 & 11,000 & 100 & 7 \\
\hline $10-06-92$ & 680 & .3 & 2,000 & 1,700 & -- & 6,900 & 6,900 & 11,000 & 11,000 & 100 & 8 \\
\hline $10-07-92$ & 700 & .3 & 2,100 & 1,700 & -- & 7,100 & 7,100 & 11,000 & 11,000 & 98 & 8 \\
\hline 08-18-93 & 850 & .4 & 760 & 610 & 220 & 7,200 & 7,200 & 12,000 & 12,000 & 96 & 8 \\
\hline $05-03-94$ & 610 & .2 & 360 & 200 & 110 & 4,600 & 4,600 & 6,500 & 6,500 & 76 & -- \\
\hline $06-24-92$ & 980 & .6 & 60,000 & 60,000 & -- & 17,000 & 17,000 & 16,000 & 16,000 & 222 & 68 \\
\hline $10-06-92$ & 800 & .5 & 57,000 & 56,000 & -- & 13,000 & 13,000 & 12,000 & 12,000 & 230 & 70 \\
\hline $10-06-92$ & 800 & .6 & 57,000 & 57,000 & -- & 13,000 & 13,000 & 14,000 & 14,000 & 222 & 70 \\
\hline $10-07-92$ & 800 & .5 & 55,000 & 55,000 & -- & 13,000 & 13,000 & 12,000 & 12,000 & 228 & 56 \\
\hline 08-18-93 & 1,000 & .5 & 58,000 & 57,000 & 47,000 & 14,000 & 14,000 & 15,000 & 15,000 & 208 & 56 \\
\hline 05-03-94 & 540 & .3 & 12,000 & 12,000 & 10,000 & 6,500 & 6,500 & 6,300 & 6,200 & 96 & 14 \\
\hline $06-24-92$ & 1,100 & .4 & 63,000 & 63,000 & -- & 8,600 & 8,600 & 18,000 & 18,000 & 250 & 130 \\
\hline 08-18-93 & 1,300 & .4 & 71,000 & $7,0,000$ & 52,000 & 8,200 & 8,200 & 20,000 & 20,000 & 280 & 116 \\
\hline 05-03-94 & 1,300 & .3 & 39,000 & 38,000 & 22,000 & 8,700 & 8,600 & 19,000 & 19,000 & 286 & 116 \\
\hline $06-25-92$ & 370 & $<.2$ & 3,400 & 3,400 & -- & 1,900 & 1,900 & 5,000 & 5,000 & 58 & 20 \\
\hline 09-09-93 & 500 & .2 & 1,900 & 1,700 & -- & 1,700 & 1,700 & 4,400 & 4,400 & 58 & 16 \\
\hline $08-31-93$ & 480 & .2 & 2,200 & 1,900 & 400 & 1,800 & 1,800 & 4,400 & 4,400 & 60 & 16 \\
\hline $05-12-94$ & 200 & $<.2$ & 990 & 880 & 240 & 800 & 780 & 1,700 & 1,700 & 32 & 8 \\
\hline $06-25-92$ & 240 & $<.2$ & 6,600 & 1,800 & -- & 870 & 730 & $<100$ & $<100$ & 0 & 0 \\
\hline $06-29-92$ & 480 & .3 & 41,000 & 38,000 & -- & 4,000 & 3,800 & 1,700 & 1,200 & 74 & -- \\
\hline $10-06-92$ & 450 & .4 & 35,000 & 35,000 & -- & 3,700 & 3,700 & 2,000 & 1,800 & 86 & 0 \\
\hline $10-07-92$ & 460 & .3 & 37,000 & 37,000 & -- & 3,900 & 3,900 & 1,800 & 1,600 & 82 & 0 \\
\hline
\end{tabular}




\begin{tabular}{|c|c|c|c|c|c|c|c|c|c|c|c|}
\hline $\begin{array}{c}\text { Site } \\
\text { number }\end{array}$ & $\begin{array}{c}\text { Local } \\
\text { identifier } \\
\text { (Topographic } \\
\text { quadrangle) }\end{array}$ & Date & Time & $\begin{array}{l}\text { Discharge, } \\
\text { instan- } \\
\text { taneous } \\
\left(\mathrm{ft}^{3} / \mathrm{s}\right)\end{array}$ & $\begin{array}{c}\text { Flow rate, } \\
\text { instan- } \\
\text { taneous } \\
\text { (gal/min) }\end{array}$ & $\begin{array}{l}\text { Temper- } \\
\text { ature, } \\
\text { water } \\
\left({ }^{\circ} \mathrm{C}\right)\end{array}$ & $\begin{array}{c}\text { Specific } \\
\text { conduc- } \\
\text { tance } \\
(\mu \mathrm{S} / \mathrm{cm})\end{array}$ & $\begin{array}{l}\mathrm{pH} \text {, water } \\
\text { whole } \\
\text { field } \\
\text { (standard } \\
\text { units) }\end{array}$ & $\begin{array}{c}\text { Alkalinity, } \\
\text { water } \\
(\mathrm{mg} / \mathrm{L} \text { as } \\
\left.\mathrm{CaCO}_{3}\right)\end{array}$ & $\begin{array}{c}\text { Residue at } \\
105^{\circ} \mathrm{C} \text {, } \\
\text { dissolved } \\
(\mathrm{mg} / \mathrm{L})\end{array}$ & $\begin{array}{c}\text { Carbon, } \\
\text { inorganic, } \\
\text { total } \\
(\mathrm{mg} / \mathrm{L} \\
\text { as C) }\end{array}$ \\
\hline & & 05-03-94 & 1315 & 9.2 & 4,130 & 9.5 & 632 & 4.8 & 8 & 536 & 23 \\
\hline 20 & Central City & $06-29-92$ & 1300 & .71 & .7 & 29.0 & 12,900 & 2.4 & 0 & 35,100 & $<1.0$ \\
\hline 21 & Stoystown & $06-29-92$ & 1400 & .10 & 46 & 21.0 & 1,170 & 3.3 & 0 & 1,480 & $<1.0$ \\
\hline \multirow[t]{4}{*}{22} & Stoystown & $06-30-92$ & 0845 & .50 & 224 & 10.0 & 1,410 & 3.0 & 0 & 1,100 & 2.5 \\
\hline & & 09-09-93 & 1025 & .30 & 135 & 12.0 & 950 & 2.9 & 0 & 1,090 & $<1.0$ \\
\hline & & $08-31-93$ & 0940 & .34 & 151 & 10.5 & 1,510 & 2.8 & 0 & 1,310 & 4.3 \\
\hline & & $05-12-94$ & 1250 & 1.2 & 553 & 9.5 & 1,170 & 3.2 & 0 & 966 & 9.3 \\
\hline 23 & Stoystown & $06-30-92$ & 0930 & .03 & 12 & 10.0 & 660 & 3.4 & 0 & 588 & 5.6 \\
\hline 24 & Stoystown & 07-01-92 & 1000 & .01 & 3.0 & 11.0 & 4,290 & 3.0 & 0 & 5,420 & 18 \\
\hline 25 & Stoystown & 07-01-92 & 1045 & .01 & 3.9 & 9.5 & 745 & 5.9 & 17 & 650 & 15 \\
\hline 26 & Stoystown & 07-01-92 & 1130 & $<.01$ & 1.5 & 15.0 & 3,000 & 3.1 & 0 & 3,900 & 3.2 \\
\hline 27 & Central City & 07-01-92 & 1600 & $<.01$ & 1.0 & 21.0 & 1,360 & 3.0 & 0 & 1,400 & $<1.0$ \\
\hline \multirow[t]{2}{*}{28} & Windber & 07-13-92 & 1045 & .19 & 84 & 10.5 & 838 & 3.1 & 0 & 800 & 4.9 \\
\hline & & 09-01-93 & 1500 & .27 & 120 & 10.5 & 953 & 3.0 & 0 & 852 & 6.1 \\
\hline 29 & Windber & $07-13-92$ & 1215 & .04 & 19 & 12.0 & 1,040 & 4.1 & 0 & 950 & 2.9 \\
\hline \multirow[t]{2}{*}{30} & Windber & $07-13-92$ & 1400 & .01 & 4.4 & 10.5 & 1,100 & 3.1 & 0 & 860 & 4.5 \\
\hline & & 09-01-93 & 1600 & .02 & 6.7 & 11.0 & 990 & 3.0 & 0 & 812 & 5.4 \\
\hline \multirow[t]{2}{*}{31} & Windber & $07-13-92$ & 1430 & .35 & 155 & 24.5 & 818 & 3.2 & 0 & 618 & $<1.0$ \\
\hline & & 09-01-93 & 1545 & .01 & $<.1$ & 26.0 & 688 & 3.3 & 0 & 534 & $<1.0$ \\
\hline 32 & Windber & 07-14-92 & 0930 & .04 & 18 & 10.5 & 1,610 & 3.4 & 0 & 1,510 & 6.2 \\
\hline 33 & Windber & 07-14-92 & 1020 & .02 & 8.4 & 17.5 & 1,410 & 3.9 & 0 & 1,350 & 1.6 \\
\hline \multirow[t]{3}{*}{34} & Stoystown & $07-15-92$ & 1130 & .09 & 42 & 11.0 & 2,230 & 2.7 & 0 & 2,040 & 8.9 \\
\hline & & $08-18-93$ & 1536 & .10 & 45 & 11.0 & 2,530 & 3.4 & 0 & 2,650 & 10 \\
\hline & & $04-21-94$ & 0930 & .35 & 156 & 10.0 & 1,390 & 3.1 & 0 & 1,300 & 15 \\
\hline 35 & Stoystown & $07-15-92$ & 1225 & .11 & 48 & 15.5 & 810 & 6.0 & 30 & 540 & 9.9 \\
\hline \multirow[t]{3}{*}{36} & Stoystown & $07-15-92$ & 1330 & .09 & 43 & 19.0 & 2,830 & 3.0 & 0 & 2,700 & $<1.0$ \\
\hline & & $08-18-93$ & 1050 & .09 & 39 & 19.0 & 2,970 & 3.4 & 0 & 3,240 & $<1.0$ \\
\hline & & 04-20-94 & 0800 & .20 & 90 & 7.5 & 2,380 & 3.2 & 0 & 2,410 & 2.5 \\
\hline 37 & Central City & 07-15-92 & 1445 & .02 & 6.8 & 10.0 & 560 & 3.6 & 0 & 2,880 & 12 \\
\hline \multirow[t]{2}{*}{38} & Central City & $07-15-92$ & 1620 & .17 & 78 & 10.0 & 1,610 & 3.0 & 0 & 1,440 & 11 \\
\hline & & 05-03-94 & 0930 & .37 & 167 & 10.5 & 1,380 & 2.6 & 0 & 1,210 & 19 \\
\hline 39 & Windber & $07-16-92$ & 1035 & .14 & 63 & 13.0 & 560 & 6.2 & 64 & 462 & 16 \\
\hline \multirow[t]{2}{*}{40} & Windber & $07-16-92$ & 1235 & .17 & 75 & 17.5 & 1,020 & 3.1 & 0 & 796 & 6.6 \\
\hline & & $08-30-93$ & 1500 & $<.01$ & .2 & 20.5 & 727 & 3.2 & 0 & 566 & $<1.0$ \\
\hline \multirow[t]{2}{*}{41} & Windber & $07-16-92$ & 1405 & .10 & 42 & 15.5 & 460 & 3.6 & 0 & 374 & 1.1 \\
\hline & & $08-30-93$ & 1500 & $<.01$ & .2 & 20.5 & 727 & 3.2 & 0 & 566 & $<1.0$ \\
\hline \multirow[t]{3}{*}{42} & Windber & 07-16-92 & 1455 & .08 & 36 & 13.5 & 2,130 & 3.1 & 0 & 2,070 & 11 \\
\hline & & 08-30-93 & 1540 & $<.01$ & .5 & 18.5 & 1,300 & 3.3 & 0 & 1,340 & 15 \\
\hline & & 05-03-94 & 1400 & .67 & 300 & 10.0 & 1,450 & 3.0 & 0 & 1,220 & 36 \\
\hline 43 & Windber & $07-16-92$ & 1620 & $<.01$ & .5 & 27.5 & 943 & 3.5 & 0 & 670 & 7.7 \\
\hline 44 & Windber & 07-17-92 & 0900 & .30 & 133 & 10.5 & 1,240 & 3.6 & 0 & 1,270 & 3.6 \\
\hline 45 & Ogletown & $07-17-92$ & 1015 & $<.01$ & .04 & 21.5 & 1,950 & 9.7 & 198 & 1,300 & 33 \\
\hline \multirow[t]{2}{*}{46} & Ogletown & $08-18-93$ & 1100 & 12 & -- & 11.5 & 934 & 6.1 & 30 & 824 & 15 \\
\hline & & $07-17-92$ & 1100 & .05 & 20 & 16.0 & 955 & 3.2 & 0 & 856 & 2.3 \\
\hline 47 & Hooversville & 08-13-92 & 1015 & $<.01$ & 1.6 & 14.5 & 1,420 & 3.2 & 0 & 1,200 & $<1.0$ \\
\hline 48 & Hooversville & 08-13-92 & 1040 & .02 & 8.0 & 15.5 & 960 & 4.5 & 0 & 796 & 2.1 \\
\hline 49 & Hooversville & 08-13-92 & 1340 & .01 & 3.4 & 11.5 & 760 & 6.7 & 140 & 548 & 40 \\
\hline 50 & Hooversville & 08-13-92 & 1445 & $<.01$ & 1.0 & 13.5 & 533 & 7.1 & 66 & 370 & 14 \\
\hline 51 & Somerset & 09-14-92 & 1140 & .04 & 18 & 11.5 & 450 & 4.3 & 0 & 346 & 2.0 \\
\hline 52 & Boswell & 09-14-92 & 1415 & $<.01$ & .2 & 17.0 & 993 & 3.8 & 0 & 778 & 1.5 \\
\hline
\end{tabular}




\begin{tabular}{|c|c|c|c|c|c|c|c|c|c|c|c|}
\hline Date & $\begin{array}{c}\text { Sulfate, } \\
\text { dissolved } \\
(\mathrm{mg} / \mathrm{L} \\
\left.\text { as } \mathrm{SO}_{4}\right)\end{array}$ & $\begin{array}{l}\text { Fluoride, } \\
\quad \text { total } \\
\text { (mg/L as F) }\end{array}$ & $\begin{array}{l}\text { Iron, total } \\
\text { recoverable } \\
(\mu \mathrm{g} / \mathrm{L} \\
\text { as } \mathrm{Fe}\end{array}$ & $\begin{array}{c}\text { Iron, } \\
\text { dissolved } \\
(\mu \mathrm{g} / \mathrm{L} \\
\text { as Fe }\end{array}$ & $\begin{array}{c}\text { Iron, } \\
\text { ferrous, } \\
\text { dissolved } \\
(\mu \mathrm{g} / \mathrm{L} \\
\text { as Fe }\end{array}$ & $\begin{array}{c}\text { Manganese, } \\
\text { total } \\
\text { recoverable } \\
(\mu \mathrm{g} / \mathrm{L} \\
\text { as Mn }\end{array}$ & $\begin{array}{c}\text { Manganese, } \\
\text { dissolved } \\
(\mu \mathrm{g} / \mathrm{L} \\
\text { as } \mathrm{Mn})\end{array}$ & $\begin{array}{l}\text { Aluminum, } \\
\text { total } \\
\text { recoverable } \\
(\mu \mathrm{g} / \mathrm{L} \\
\text { as Al) }\end{array}$ & $\begin{array}{c}\text { Aluminum, } \\
\text { dissolved } \\
(\mu \mathrm{g} / \mathrm{L} \\
\text { as Al) }\end{array}$ & $\begin{array}{c}\text { Acidity, } \\
\text { total } \\
\text { heated } \\
(\mathrm{mg} / \mathrm{L} \text { as } \\
\left.\mathrm{CaCO}_{3}\right)\end{array}$ & $\begin{array}{c}\text { Acidity, } \\
\text { mineral } \\
\text { (methyl } \\
\text { orange) } \\
(\mathrm{mg} / \mathrm{L} \text { as } \\
\left.\mathrm{CaCO}_{3}\right)\end{array}$ \\
\hline 05-03-94 & 370 & 0.2 & 16,000 & 14,000 & 220 & 2,700 & 2,700 & 1,400 & 910 & 52 & -- \\
\hline $06-29-92$ & 27,000 & 4.2 & $4,760,000$ & $4,360,000$ & -- & 60,000 & 60,000 & 160,000 & 160,000 & 19,688 & 8,170 \\
\hline $06-29-92$ & 630 & $<.2$ & 6,900 & 7,600 & -- & 7,100 & 7,700 & 1,100 & 1,200 & 62 & 38 \\
\hline $06-30-92$ & 750 & .4 & 30,000 & 30,000 & -- & 7,500 & 7,500 & 9,600 & 9,500 & 200 & 130 \\
\hline 09-09-93 & 880 & .4 & 24,000 & 23,000 & -- & 7,400 & 7,200 & 9,500 & 9,200 & 174 & 94 \\
\hline $08-31-93$ & 930 & .3 & 34,000 & 33,000 & 660 & 8,700 & 8,700 & 11,000 & 11,000 & 230 & 126 \\
\hline $05-12-94$ & 730 & .3 & 21,000 & 21,000 & 610 & 7,100 & 7,100 & 12,000 & 11,000 & 172 & 80 \\
\hline $06-30-92$ & 360 & .3 & 300 & 280 & -- & 9,000 & 8,700 & 12,000 & 11,000 & 100 & 17 \\
\hline $07-01-92$ & 3,400 & 1.8 & 210,000 & 190,000 & -- & 130,000 & 120,000 & 63,000 & 62,000 & 840 & 190 \\
\hline $07-01-92$ & 420 & $<.2$ & 68,000 & 67,000 & -- & 4,000 & 4,000 & $<100$ & $<100$ & 100 & 0 \\
\hline 07-01-92 & 2,200 & 1.1 & 23,000 & 23,000 & -- & 56,000 & 56,000 & 55,000 & 55,000 & 490 & 100 \\
\hline 07-01-92 & 880 & .4 & 30,000 & 30,000 & -- & 12,000 & 12,000 & 42,000 & 42,000 & 420 & 120 \\
\hline $07-13-92$ & 430 & .3 & 1,200 & 1,200 & -- & 5,800 & 5,700 & 10,000 & 9,900 & 100 & 32 \\
\hline 09-01-93 & 690 & .3 & 1,700 & 1,700 & 170 & 5,700 & 5,700 & 12,000 & 12,000 & 114 & 28 \\
\hline $07-13-92$ & 620 & .2 & 30 & 30 & -- & 1,400 & 1,400 & 7,100 & 7,100 & 52 & 0 \\
\hline $07-13-92$ & 470 & .4 & 2,100 & 2,100 & -- & 7,600 & 7,600 & 14,000 & 14,000 & 140 & 40 \\
\hline 09-01-93 & 680 & .4 & 2,100 & 2,100 & 290 & 7,500 & 7,500 & 15,000 & 15,000 & 124 & 36 \\
\hline $07-13-92$ & 360 & .3 & 2,000 & 2,000 & -- & 5,700 & 5,600 & 9,200 & 9,100 & 98 & 30 \\
\hline 09-01-93 & 430 & .3 & 2,400 & 2,400 & 1,300 & 4,300 & 4,300 & 6,100 & 6,100 & 68 & 24 \\
\hline $07-14-92$ & 960 & .4 & 1,100 & 900 & -- & 4,300 & 4,200 & 6,300 & 6,100 & 64 & 12 \\
\hline $07-14-92$ & 860 & .3 & 330 & 290 & -- & 5,700 & 5,700 & 5,000 & 5,000 & 44 & 0 \\
\hline $07-15-92$ & 1,200 & .8 & 32,000 & 32,000 & -- & 14,000 & 14,000 & 21,000 & 21,000 & 310 & 150 \\
\hline 08-18-93 & 1,600 & .9 & 45,000 & 44,000 & 2,800 & 16,000 & 16,000 & 28,000 & 28,000 & 404 & 204 \\
\hline $04-21-94$ & 900 & .5 & 12,000 & 11,000 & 1,100 & 6,500 & 6,500 & 10,000 & 10,000 & -- & 52 \\
\hline 07-15-92 & 300 & .2 & 5,200 & 4,800 & -- & 3,200 & 3,200 & 1,600 & 200 & 0 & 0 \\
\hline 07-15-92 & 1,800 & .2 & 13,000 & 13,000 & -- & 42,000 & 42,000 & 2,900 & 2,900 & 160 & 84 \\
\hline 08-18-93 & 2,600 & .2 & 25,000 & 22,000 & 7,900 & 46,000 & 45,000 & 2,700 & 2,700 & 248 & 94 \\
\hline $04-20-94$ & 1,900 & .6 & 16,000 & 15,000 & 13,000 & 37,000 & 37,000 & 9,100 & 9,000 & 232 & 0 \\
\hline 07-15-92 & 260 & .2 & 1,100 & 970 & -- & 3,100 & 2,800 & 2,300 & 2,300 & 36 & 7 \\
\hline 07-15-92 & 850 & -- & 66,000 & 66,000 & -- & 6,500 & 6,500 & 42,000 & 41,000 & 442 & 78 \\
\hline 05-03-94 & 840 & .2 & 34,000 & 34,000 & 25,000 & 4,400 & 4,400 & 31,000 & 31,000 & 384 & 112 \\
\hline 07-16-92 & 210 & $<.2$ & 820 & 390 & -- & 610 & 600 & $<100$ & $<100$ & 0 & 0 \\
\hline 07-16-92 & 420 & .6 & 4,800 & 4,800 & -- & 5,400 & 5,400 & 14,000 & 14,000 & 164 & 44 \\
\hline 08-30-93 & 450 & .4 & 3,400 & 3,200 & 400 & 13,000 & 13,000 & 8,600 & 8,300 & 102 & 28 \\
\hline 07-16-92 & 200 & .4 & 3,000 & 1,200 & -- & 3,200 & 3,200 & 6,400 & 4,500 & 62 & 9 \\
\hline 07-07-93 & 490 & $<.2$ & 78,000 & 76,000 & -- & 4,100 & 4,100 & 290 & $<130$ & 120 & -- \\
\hline 07-16-92 & 1,300 & .6 & 5,400 & 5,300 & -- & 26,000 & 26,000 & 14,000 & 14,000 & 200 & 56 \\
\hline 08-30-93 & 850 & .3 & 2,600 & 2,000 & 600 & 12,000 & 12,000 & 5,000 & 4,900 & 74 & 22 \\
\hline 05-03-94 & 930 & .3 & 2,300 & 2,200 & 280 & 15,000 & 15,000 & 7,100 & 7,100 & 142 & 30 \\
\hline $07-16-92$ & 360 & $<.2$ & 27,000 & 26,000 & -- & 9,700 & 9,700 & 7,800 & 7,800 & 138 & 34 \\
\hline 07-17-92 & 720 & .3 & 140 & 140 & -- & 2,500 & 2,500 & 5,400 & 5,400 & 62 & 6 \\
\hline 07-17-92 & 860 & .3 & 290 & $<10$ & -- & 5,500 & 1,500 & 4,200 & 730 & 0 & -- \\
\hline 08-18-93 & 480 & $<.2$ & 57,000 & 41,000 & -- & 4,700 & 4,600 & $<130$ & $<130$ & 56 & -- \\
\hline 07-17-92 & 490 & .4 & 7,500 & 7,300 & -- & 4,900 & 4,900 & 22,000 & 22,000 & 210 & 46 \\
\hline 08-13-92 & 770 & .6 & 38,000 & 37,000 & -- & 14,000 & 14,000 & 9,200 & 8,900 & 192 & 66 \\
\hline 08-13-92 & 560 & .2 & 6,400 & 5,300 & -- & 9,100 & 9,100 & 3,200 & 2,800 & 50 & 0 \\
\hline 08-13-92 & 270 & $<.2$ & 4,800 & 2,600 & -- & 830 & 760 & $<130$ & $<130$ & 0 & -- \\
\hline 08-13-92 & 200 & $<.2$ & 330 & 31 & -- & 24 & 14 & $<130$ & $<130$ & 0 & -- \\
\hline 09-14-92 & 200 & $<.2$ & 300 & 230 & -- & 410 & 410 & 2,300 & 2,100 & 24 & 0 \\
\hline 09-14-92 & 550 & $<.2$ & 9,500 & 6,600 & -- & 2,600 & 2,600 & 4,200 & 800 & 50 & 12 \\
\hline
\end{tabular}




\begin{tabular}{|c|c|c|c|c|c|c|c|c|c|c|c|}
\hline $\begin{array}{l}\text { Site } \\
\text { number }\end{array}$ & $\begin{array}{c}\text { Local } \\
\text { identifier } \\
\text { (Topographic } \\
\text { quadrangle) }\end{array}$ & Date & Time & $\begin{array}{l}\text { Discharge, } \\
\text { instan- } \\
\text { taneous } \\
\left(\mathrm{ft}^{3} / \mathrm{s}\right)\end{array}$ & $\begin{array}{c}\text { Flow rate, } \\
\text { instan- } \\
\text { taneous } \\
\text { (gal/min) }\end{array}$ & $\begin{array}{l}\text { Temper- } \\
\text { ature, } \\
\text { water } \\
\left({ }^{\circ} \mathrm{C}\right)\end{array}$ & $\begin{array}{c}\text { Specific } \\
\text { conduc- } \\
\text { tance } \\
(\mu \mathrm{S} / \mathrm{cm})\end{array}$ & $\begin{array}{l}\mathrm{pH} \text {, water } \\
\text { whole } \\
\text { field } \\
\text { (standard } \\
\text { units) }\end{array}$ & $\begin{array}{l}\text { Alkalinity, } \\
\text { water } \\
(\mathrm{mg} / \mathrm{L} \text { as } \\
\left.\mathrm{CaCO}_{3}\right)\end{array}$ & $\begin{array}{c}\text { Residue at } \\
105^{\circ} \mathrm{C} \text {, } \\
\text { dissolved } \\
\text { (mg/L) }\end{array}$ & $\begin{array}{c}\text { Carbon, } \\
\text { inorganic, } \\
\text { total } \\
(\mathrm{mg} / \mathrm{L} \\
\text { as C) }\end{array}$ \\
\hline 53 & Boswell & $09-14-92$ & 1450 & .01 & 4.6 & 14.5 & 900 & 3.6 & 0 & 780 & $<1.0$ \\
\hline 54 & Boswell & 09-14-92 & 1615 & .25 & 111 & 11.0 & 333 & 6.7 & 72 & 212 & 10 \\
\hline 55 & Berlin & $05-19-93$ & 1020 & .10 & 45 & 8.0 & 1,080 & 5.7 & 46 & 864 & 38 \\
\hline 56 & Berlin & $05-19-93$ & 1045 & $<.10$ & 20 & 10.0 & 439 & 4.2 & 0 & 372 & 19 \\
\hline 57 & Berlin & $05-19-93$ & 1115 & $<.01$ & 1.6 & 14.0 & 937 & 5.5 & 42 & 1,140 & 26 \\
\hline 58 & New Baltimore & 05-19-93 & 1330 & .08 & 35 & 9.5 & 1,300 & 5.9 & 52 & 1,240 & 23 \\
\hline 59 & Stoystown & 05-19-93 & 1645 & .01 & 3.1 & 12.0 & 4,190 & 2.9 & 0 & 4,420 & 11 \\
\hline 60 & Stoystown & 05-19-93 & 1730 & .01 & 6.4 & 14.0 & 5,410 & 2.9 & 0 & 8,060 & 5.8 \\
\hline 61 & Stoystown & $05-20-93$ & 0920 & .13 & 60 & 12.5 & 305 & 6.7 & 96 & 214 & 22 \\
\hline 62 & Stoystown & $05-25-93$ & 1015 & .12 & 52 & 8.0 & 506 & 3.5 & 0 & 324 & 5.0 \\
\hline \multirow[t]{2}{*}{63} & \multirow[t]{2}{*}{ Stoystown } & $05-25-93$ & 1130 & .62 & 277 & 14.5 & 977 & 3.4 & 0 & 742 & 9.3 \\
\hline & & 04-20-94 & 0940 & 1.8 & 805 & 9.5 & 881 & 3.1 & 0 & 562 & 4.8 \\
\hline 64 & Stoystown & $05-25-93$ & 1300 & .04 & 19 & 18.5 & 608 & 6.4 & 26 & 494 & 7.8 \\
\hline 65 & Stoystown & $05-26-93$ & 0830 & .13 & 58 & 10.5 & 345 & 5.8 & 11 & 284 & 6.4 \\
\hline 66 & Stoystown & $05-26-93$ & 0920 & .13 & 58 & 15.0 & 343 & 6.8 & 38 & 200 & 8.6 \\
\hline 67 & Stoystown & 06-01-93 & 1030 & $<.01$ & 2.0 & 14.0 & 1,170 & 4.2 & 3 & 1,240 & 2.2 \\
\hline 68 & Stoystown & 06-01-93 & 1145 & .01 & 4.6 & 11.0 & 1,920 & 6.7 & 270 & 2,930 & 1.0 \\
\hline 69 & Stoystown & 06-01-93 & 1245 & $<.01$ & .4 & 16.0 & 1,310 & 3.7 & 0 & 1,330 & $<1.0$ \\
\hline 70 & Stoystown & 06-01-93 & 1330 & .09 & 41 & 10.0 & 699 & 4.0 & 0 & 1,240 & 6.3 \\
\hline 71 & Stoystow & 06-01-93 & 1530 & .01 & 3.8 & 20.5 & 1,520 & 3.8 & 0 & 3,090 & 3.5 \\
\hline 72 & Stoystown & 06-01-93 & 1600 & .02 & 8.6 & 12.0 & 1,900 & 3.7 & 0 & 2,320 & 3.9 \\
\hline 73 & Stoystown & 06-01-93 & 1700 & $<.01$ & 1.6 & 11.0 & 4,200 & 3.5 & 0 & 5,430 & $<1.0$ \\
\hline 74 & Stoystown & $06-02-93$ & 0830 & .01 & 2.4 & 9.5 & 359 & 6.5 & 30 & 394 & 9.9 \\
\hline 75 & Central City & $07-12-93$ & 1000 & .07 & 30 & 24.0 & 830 & 3.3 & 0 & 628 & 1.3 \\
\hline 76 & Central City & $07-12-93$ & 1030 & .08 & 35 & 12.5 & 776 & 3.4 & 0 & 740 & 30 \\
\hline 77 & Stoystown & 06-01-93 & 1530 & .01 & 3.8 & 20.5 & 1,520 & 3.8 & 0 & 3,090 & 3.5 \\
\hline 78 & Windber & $07-12-93$ & 1530 & .14 & 65 & 11.5 & 1,070 & 4.5 & 12 & 1,400 & 11 \\
\hline 79 & Geistown & $07-12-93$ & 1630 & $<.01$ & 2.0 & 31.0 & 4,660 & 2.2 & 0 & 9,240 & 4.5 \\
\hline 80 & Windber & 07-13-93 & 0840 & $<.01$ & .4 & 22.0 & 2,520 & 2.7 & 0 & 1,860 & 2.0 \\
\hline 81 & Windber & 07-13-93 & 1010 & 3.1 & 1400 & 11.5 & 1,020 & 4.8 & 3 & 954 & 6.0 \\
\hline 82 & Central City & 08-18-93 & 1100 & .03 & 12 & 11.5 & 934 & 6.1 & 30 & 824 & 15 \\
\hline 83 & Central City & 08-18-93 & 1310 & $<.01$ & .8 & 14.0 & 2,080 & 4.5 & 0 & 2,310 & 2.7 \\
\hline 84 & Central City & 08-30-93 & 1050 & $<.01$ & .5 & 9.0 & 2,490 & 6.1 & 84 & 3,230 & 33 \\
\hline 85 & Windber & $08-30-93$ & 1230 & .01 & 2.5 & 14.0 & 505 & 4.6 & 0 & 462 & 2.4 \\
\hline 86 & Windber & $08-30-93$ & 1345 & .02 & 9.0 & 18.0 & 336 & 6.6 & 15 & 284 & 3.2 \\
\hline 87 & Stoystown & $08-30-93$ & 1640 & $<.01$ & 1.8 & 20.5 & 1,160 & 6.4 & 48 & 1,090 & 15 \\
\hline 88 & Hooversville & $09-22-93$ & 1015 & $<.01$ & 1.2 & 11.5 & 570 & 6.5 & 20 & 496 & 5.1 \\
\hline 89 & Hooversville & $09-22-93$ & 1050 & $<.01$ & 1.5 & 12.5 & 993 & 3.5 & 0 & 908 & 8.5 \\
\hline 90 & Hooversville & $09-22-93$ & 1200 & $<.01$ & 1.9 & 10.0 & 1,160 & 2.9 & 0 & 744 & 5.2 \\
\hline 91 & Hooversville & $09-22-93$ & 1600 & $<.01$ & 1.5 & 15.5 & 665 & 6.8 & 96 & 534 & 21 \\
\hline 92 & Hooversville & $09-22-93$ & 1700 & $<.01$ & 1.7 & 14.5 & 1,820 & 5.8 & 3 & 1,920 & $<1.0$ \\
\hline 93 & Hooversville & $09-23-93$ & 0915 & $<.01$ & 2.2 & 9.5 & 860 & 3.6 & 0 & 720 & 20 \\
\hline 94 & Hooversville & $09-23-93$ & 1020 & $<.01$ & 2.5 & 16.5 & 3,670 & 3.0 & 0 & 4,630 & $<1.0$ \\
\hline 95 & Hooversville & $05-11-94$ & 0830 & 2.2 & 981 & 10.0 & 1,060 & 4.6 & 0 & 986 & 5.6 \\
\hline 96 & Windber & 05-17-94 & 1315 & .12 & 52 & 10.0 & 1,120 & 6.3 & 26 & 1,070 & 7.5 \\
\hline \multirow[t]{2}{*}{97} & \multirow[t]{2}{*}{ Hooversville } & 05-17-94 & 1650 & .44 & 197 & 11.0 & 1,530 & 3.2 & 0 & 1,460 & 2.3 \\
\hline & & $11-17-94$ & 0900 & .12 & 54 & 11.0 & 1,310 & 4.1 & 0 & 1,410 & 22 \\
\hline 98 & Central City & 05-24-94 & 1730 & .01 & 2.4 & 14.0 & 726 & 6.1 & 28 & 594 & 11 \\
\hline 99 & Central City & 05-24-94 & 1820 & $<.01$ & .4 & 15.0 & 1,620 & 6.2 & 18 & 2,000 & 6.6 \\
\hline 100 & Windber & 05-25-94 & 0900 & .79 & 352 & 10.0 & 720 & 5.8 & 12 & 622 & 8.3 \\
\hline
\end{tabular}




\begin{tabular}{|c|c|c|c|c|c|c|c|c|c|c|c|}
\hline Date & $\begin{array}{l}\text { Sulfate, } \\
\text { dissolved } \\
(\mathrm{mg} / \mathrm{L} \\
\left.\text { as } \mathrm{SO}_{4}\right)\end{array}$ & $\begin{array}{c}\text { Fluoride, } \\
\text { total } \\
\text { (mg/L as F) }\end{array}$ & $\begin{array}{l}\text { Iron, total } \\
\text { recoverable } \\
(\mu \mathrm{g} / \mathrm{L} \\
\text { as Fe }\end{array}$ & $\begin{array}{c}\text { Iron, } \\
\text { dissolved } \\
(\mu \mathrm{g} / \mathrm{L} \\
\text { as Fe }\end{array}$ & $\begin{array}{c}\text { Iron, } \\
\text { ferrous, } \\
\text { dissolved } \\
(\mu \mathrm{g} / \mathrm{L} \\
\text { as } \mathrm{Fe}\end{array}$ & $\begin{array}{c}\text { Manganese, } \\
\text { total } \\
\text { recoverable } \\
(\mu \mathrm{g} / \mathrm{L} \\
\text { as } \mathrm{Mn}\end{array}$ & $\begin{array}{c}\text { Manganese, } \\
\text { dissolved } \\
(\mu \mathrm{g} / \mathrm{L} \\
\text { as } \mathrm{Mn})\end{array}$ & $\begin{array}{c}\text { Aluminum, } \\
\text { total } \\
\text { recoverable } \\
(\mu \mathrm{g} / \mathrm{L} \\
\text { as Al) }\end{array}$ & $\begin{array}{c}\text { Aluminum, } \\
\text { dissolved } \\
(\mu \mathrm{g} / \mathrm{L} \\
\text { as Al) }\end{array}$ & $\begin{array}{c}\text { Acidity, } \\
\text { total } \\
\text { heated } \\
(\mathrm{mg} / \mathrm{L} \text { as } \\
\left.\mathrm{CaCO}_{3}\right)\end{array}$ & $\begin{array}{c}\text { Acidity, } \\
\text { mineral } \\
\text { (methyl } \\
\text { orange) } \\
(\mathrm{mg} / \mathrm{L} \text { as } \\
\left.\mathrm{CaCO}_{3}\right)\end{array}$ \\
\hline 09-14-92 & 510 & 0.3 & 1,200 & 1,200 & -- & 680 & 650 & 7,800 & 7,700 & 72 & 11 \\
\hline 09-14-92 & 97 & $<.2$ & 7,900 & 7,700 & -- & 630 & 620 & $<140$ & $<140$ & 0 & 0 \\
\hline $05-19-93$ & 630 & $<.1$ & 72,000 & 72,000 & -- & 10,000 & 10,000 & $<130$ & $<130$ & 94 & -- \\
\hline 05-19-93 & 230 & $<.2$ & 240 & 220 & -- & 5,300 & 5,300 & 3,600 & 3,500 & 32 & -- \\
\hline $05-19-93$ & 630 & $<.2$ & 130,000 & 120,000 & -- & 20,000 & 19,000 & $<130$ & $<130$ & 204 & -- \\
\hline 05-19-93 & 790 & .6 & 47,000 & 46,000 & -- & 4,400 & 4,400 & 540 & 510 & 46 & -- \\
\hline $05-19-93$ & 2,700 & 1.4 & 73,000 & 73,000 & 72,000 & 78,000 & 78,000 & 55,000 & 55,000 & 660 & 142 \\
\hline $05-19-93$ & 5,000 & 2.2 & 18,000 & 18,000 & 4,400 & 140,000 & 140,000 & 86,000 & 86,000 & 720 & 122 \\
\hline $05-20-93$ & 21 & $<.2$ & 2,000 & 1,500 & -- & 150 & 140 & $<130$ & $<130$ & 0 & -- \\
\hline $05-25-93$ & 260 & .3 & 360 & 230 & 140 & 4,900 & 4,900 & 9,000 & 9,000 & 64 & 8 \\
\hline $05-25-93$ & 260 & .4 & 4,100 & 4,100 & 3,000 & 7,800 & 7,800 & 19,000 & 19,000 & 140 & 26 \\
\hline $04-20-94$ & 460 & .3 & 2,300 & 2,300 & 1,600 & 5,600 & 5,600 & 17,000 & 17,000 & 176 & 26 \\
\hline $05-25-93$ & 300 & $<.2$ & 2,900 & 1,400 & -- & 1,700 & 1,600 & $<100$ & $<100$ & 0 & 0 \\
\hline $05-26-93$ & 140 & $<.2$ & 170 & $<10$ & -- & 120 & 120 & $<130$ & $<130$ & 0 & -- \\
\hline $05-26-93$ & 120 & $<.2$ & 500 & 110 & -- & 260 & 250 & $<130$ & $<130$ & 0 & -- \\
\hline $06-01-93$ & 770 & $<.2$ & 3,000 & 1,500 & -- & 9,000 & 8,300 & 2,200 & 1800 & 36 & -- \\
\hline $06-01-93$ & 1,900 & $<.2$ & 130 & 110 & 0 & 1,400 & 1,400 & $<100$ & $<100$ & 0 & 0 \\
\hline 06-01-93 & 870 & .4 & 620 & 580 & 360 & 11,000 & 11,000 & 23,000 & 23,000 & 190 & 28 \\
\hline $06-01-93$ & 800 & .5 & 210 & 190 & 130 & 16,000 & 16,000 & 17,000 & 17,000 & 146 & 13 \\
\hline 06-01-93 & 2,200 & .8 & 2,200 & 2,200 & 1,400 & 59,000 & 59,000 & 68,000 & 68,000 & 532 & 34 \\
\hline $06-01-93$ & 1,400 & .7 & 800 & 600 & 520 & 44,000 & 44,000 & 56,000 & 56,000 & 440 & 32 \\
\hline 06-01-93 & 4,000 & 1.3 & 90,000 & 90,000 & 260 & 120,000 & 120,000 & 57,000 & 57,000 & 780 & 216 \\
\hline $06-02-93$ & 150 & $<.2$ & 11,000 & 11,000 & 0 & 3,800 & 3,700 & 200 & $<130$ & 8.0 & 0 \\
\hline $07-12-93$ & 490 & .2 & 5,500 & 3,900 & -- & 3,400 & 3,400 & 3,400 & 3,400 & 80 & 24 \\
\hline 07-12-93 & 570 & .2 & 17,000 & 17,000 & 8,000 & 3,200 & 3,100 & 9,800 & 9,800 & 126 & 36 \\
\hline 06-01-93 & 2,200 & .8 & 2,200 & 2,200 & 1,400 & 59,000 & 59,000 & 68,000 & 68,000 & 532 & 34 \\
\hline 07-12-93 & 870 & $<.2$ & 30 & 10 & -- & 1,200 & 1,200 & 810 & 810 & 28 & -- \\
\hline 07-12-93 & 6,200 & .2 & $1,300,000$ & -- & -- & 10,000 & 9,800 & 100,000 & 99,000 & 3,940 & 2,940 \\
\hline 07-13-93 & 1,300 & $<.2$ & 130,000 & 130,000 & 46,000 & 6,100 & 6,100 & 26,000 & 26,000 & 700 & 440 \\
\hline 07-13-93 & 720 & $<.2$ & 6,900 & 6,900 & -- & 2,800 & 2,700 & 2,600 & 1,900 & 44 & -- \\
\hline 08-18-93 & 480 & $<.2$ & 57,000 & 41,000 & -- & 4,700 & 4,600 & $<130$ & $<130$ & 56 & -- \\
\hline 08-18-93 & 1,500 & .2 & 620 & 490 & -- & 1,500 & 1,500 & 1,100 & 1,100 & 18 & -- \\
\hline 08-30-93 & 2,100 & $<.2$ & 40,000 & 38,000 & -- & 9,900 & 9,900 & 240 & $<130$ & 0 & -- \\
\hline 08-30-93 & 280 & $<.2$ & 1,900 & 1,200 & -- & 2,600 & 2,300 & 130 & $<130$ & 11 & -- \\
\hline 08-30-93 & 140 & $<.2$ & 610 & 52 & -- & 500 & 490 & $<130$ & $<130$ & 0 & -- \\
\hline 08-30-93 & 590 & $<.2$ & 11,000 & 8,400 & -- & 4,300 & 4,200 & 150 & 150 & 0 & -- \\
\hline 09-22-93 & 260 & .2 & $<10$ & $<10$ & -- & 60 & 60 & 210 & $<130$ & 0 & -- \\
\hline $09-22-93$ & 600 & .2 & 19,000 & 19,000 & 13,000 & 4,300 & 4,300 & 3,400 & 3,400 & 82 & 22 \\
\hline $09-22-93$ & 560 & .3 & 4,700 & 4,700 & 320 & 1,200 & 1,200 & 7,300 & 7,300 & 124 & 64 \\
\hline $09-22-93$ & 230 & .2 & 120 & 18 & -- & 88 & 83 & 440 & $<130$ & 0 & -- \\
\hline 09-22-93 & 1,100 & $<.2$ & 1,000 & $<10$ & -- & 1,200 & 1,200 & 480 & 240 & 12 & -- \\
\hline 09-23-93 & 460 & .3 & 490 & 470 & 150 & 2,400 & 2,300 & 1,100 & 1,000 & 34 & 7 \\
\hline 09-23-93 & 1,700 & .7 & 130,000 & 130,000 & 96,000 & 150,000 & 150,000 & 26,000 & 25,000 & 714 & 200 \\
\hline $05-11-94$ & 690 & .3 & 3,500 & 2,300 & -- & 2,000 & 2,000 & 3,000 & 2,900 & 30 & -- \\
\hline 05-17-94 & 700 & $<.2$ & 610 & 530 & -- & 460 & 450 & 230 & $<130$ & 0 & -- \\
\hline 05-17-94 & 1,000 & .3 & 28,000 & 28,000 & 23,000 & 1,400 & 1,400 & 15,000 & 15,000 & 186 & 44 \\
\hline $11-17-94$ & 700 & .2 & 53,000 & 53,000 & 53,000 & 1,300 & 1,300 & 6,100 & 6,100 & 204 & -- \\
\hline 05-24-94 & 470 & $<.2$ & 8,900 & 4,500 & -- & 2,000 & 1,600 & 220 & $<130$ & 0 & -- \\
\hline 05-24-94 & 1,400 & $<.2$ & 20,000 & 18,000 & -- & 12,000 & 12,000 & 160 & 150 & 26 & -- \\
\hline 05-25-94 & 420 & $<.2$ & 50 & 23 & -- & 690 & 690 & 700 & 440 & 1.2 & -- \\
\hline
\end{tabular}




\begin{tabular}{|c|c|c|c|c|c|c|c|c|c|c|c|}
\hline $\begin{array}{l}\text { Site } \\
\text { number }\end{array}$ & $\begin{array}{c}\text { Local } \\
\text { identifier } \\
\text { (Topographic } \\
\text { quadrangle) }\end{array}$ & Date & Time & $\begin{array}{l}\text { Discharge, } \\
\text { instan- } \\
\text { taneous } \\
\left(\mathrm{ft}^{3} / \mathrm{s}\right)\end{array}$ & $\begin{array}{c}\text { Flow rate, } \\
\text { instan- } \\
\text { taneous } \\
\text { (gal/min) }\end{array}$ & $\begin{array}{l}\text { Temper- } \\
\text { ature, } \\
\text { water } \\
\left({ }^{\circ} \mathrm{C}\right)\end{array}$ & $\begin{array}{c}\text { Specific } \\
\text { conduc- } \\
\text { tance } \\
(\mu \mathrm{S} / \mathrm{cm})\end{array}$ & $\begin{array}{l}\mathrm{pH} \text {, water } \\
\text { whole } \\
\text { field } \\
\text { (standard } \\
\text { units) }\end{array}$ & $\begin{array}{l}\text { Alkalinity, } \\
\text { water } \\
(\mathrm{mg} / \mathrm{L} \text { as } \\
\left.\mathrm{CaCO}_{3}\right)\end{array}$ & $\begin{array}{c}\text { Residue at } \\
105^{\circ} \mathrm{C} \text {, } \\
\text { dissolved } \\
\text { (mg/L) }\end{array}$ & $\begin{array}{c}\text { Carbon, } \\
\text { inorganic, } \\
\text { total } \\
(\mathrm{mg} / \mathrm{L} \\
\text { as C) }\end{array}$ \\
\hline 101 & Windber & $05-25-94$ & 1000 & .26 & 117 & 10.5 & 1,310 & 3.2 & 0 & 1,180 & 3.5 \\
\hline 102 & Windber & $05-25-94$ & 1230 & .03 & 15 & 13.0 & 186 & 4.7 & 0 & 270 & 1.5 \\
\hline \multirow[t]{2}{*}{103} & Windber & 05-25-94 & 1310 & .97 & 436 & 10.5 & 1,350 & 3.2 & 0 & 1,250 & 3.3 \\
\hline & & $11-17-94$ & 1045 & .07 & 33 & 10.0 & 3,110 & 2.7 & 0 & 3,780 & 2.4 \\
\hline \multirow[t]{2}{*}{104} & Windber & 05-25-94 & 1400 & .44 & 200 & 11.0 & 2,400 & 3.0 & 0 & 2,270 & 3.6 \\
\hline & & $11-17-94$ & 1110 & .05 & 22 & 10.0 & 2,990 & 3.3 & 0 & 3,190 & 2.0 \\
\hline 105 & Stoystown & 05-26-94 & 0840 & .01 & 6.0 & 12.5 & 328 & 3.7 & 0 & 222 & 4.0 \\
\hline 106 & Central City & $06-07-94$ & 1305 & .11 & 51 & 16.5 & 210 & 7.1 & 78 & 180 & 6.4 \\
\hline 107 & Johnstown & 06-14-94 & 0950 & .02 & 9.2 & 11.5 & 715 & 5.2 & 4 & 528 & 5.9 \\
\hline 108 & Johnstown & 06-14-94 & 1030 & .13 & 60 & 11.0 & 810 & 7.0 & 48 & 642 & 12 \\
\hline 109 & Johnstown & 06-14-94 & 1120 & .40 & 180 & 15.5 & 1,230 & 5.9 & 44 & 1,200 & 2.3 \\
\hline \multirow[t]{2}{*}{110} & Geistown & 06-14-94 & 1300 & 1.0 & 449 & 13.0 & 1,220 & 4.5 & 0 & 1,310 & 4.6 \\
\hline & & $11-21-94$ & 1250 & .88 & 396 & 12.5 & 1,420 & 3.0 & 0 & 1,260 & 11 \\
\hline 111 & Windber & 06-20-94 & 1050 & .07 & 30 & 12.0 & 992 & 3.4 & 0 & 1,000 & 2.1 \\
\hline 112 & Windber & $06-22-94$ & 1115 & .03 & 12 & 10.0 & 1,430 & 3.5 & 0 & 1,530 & 3.1 \\
\hline 113 & Windber & $06-22-94$ & 1140 & .02 & 7.9 & 10.0 & 1,610 & 3.3 & 0 & 1,590 & 3.3 \\
\hline 114 & Windber & 06-22-94 & 1215 & .01 & 5.5 & 17.5 & 1,620 & 3.5 & 0 & 1,780 & $<1.0$ \\
\hline 115 & Windber & $06-22-94$ & 1430 & .01 & 3.9 & 18.0 & 1,840 & 3.6 & 0 & 2,090 & $<1.0$ \\
\hline 116 & Windber & $06-22-94$ & 1500 & .03 & 15 & 18.0 & 1,410 & 3.6 & 0 & 1,490 & $<1.0$ \\
\hline 117 & Beaverdale & $06-27-94$ & 1110 & .05 & 21 & 15.5 & 2,470 & 3.1 & 0 & 4,360 & 3.2 \\
\hline 118 & Beaverdale & 06-27-94 & 1130 & $<.01$ & .3 & 19.0 & 2,380 & 2.6 & 0 & 3,150 & 1.4 \\
\hline 119 & Hooversville & $06-27-94$ & 1550 & .01 & 4.0 & 15.5 & 177 & 5.0 & 3 & 140 & 5.9 \\
\hline 120 & Hooversville & $06-27-94$ & 1645 & .02 & 7.5 & 20.0 & 810 & 3.2 & 0 & 474 & 1.0 \\
\hline 121 & Hooversville & 06-28-94 & 0810 & 3.4 & 1,510 & 12.0 & 718 & 6.0 & 18 & 662 & 9.4 \\
\hline 122 & Hooversville & 06-28-94 & 0840 & $<.01$ & .2 & 18.0 & 5,010 & 2.9 & 0 & 10,880 & 2.7 \\
\hline 123 & Hooversville & 06-28-94 & 0930 & .55 & 248 & 10.0 & 804 & 6.4 & 68 & 728 & 20 \\
\hline \multirow[t]{2}{*}{124} & Windber & 07-06-94 & 0945 & .04 & 18 & 14.5 & 3,350 & 2.6 & 0 & 4,260 & 4.2 \\
\hline & & $11-17-94$ & 1240 & $<.01$ & .7 & 13.0 & 3,060 & 3.2 & 0 & 3,380 & 9.0 \\
\hline \multirow[t]{2}{*}{125} & Windber & 07-06-94 & 1030 & .50 & 225 & 23.0 & 3,670 & 2.4 & 0 & 5,070 & $<1.0$ \\
\hline & & $11-17-94$ & 1300 & .02 & 10 & 9.5 & 3,030 & 2.6 & 0 & 3,630 & 1.3 \\
\hline 126 & Windber & 07-06-94 & 1100 & .06 & 26 & 17.5 & 1,430 & 2.9 & 0 & 1,370 & $<1.0$ \\
\hline 127 & Windber & 07-06-94 & 1150 & $<.01$ & 1.3 & 22.5 & 2,340 & 2.6 & 0 & 2,370 & 1.2 \\
\hline 128 & Stoystown & 07-06-94 & 1620 & .06 & 28 & 12.5 & 1,520 & 3.6 & 0 & 1,690 & 8.0 \\
\hline 129 & Stoystown & 07-06-94 & 1700 & .04 & 17 & 14.5 & 2,060 & 3.7 & 0 & 2,550 & 7.5 \\
\hline 130 & Johnstown & 07-07-94 & 0840 & .56 & 250 & 12.0 & 1,170 & 3.9 & 0 & 1,150 & 1.2 \\
\hline 131 & Johnstown & 07-07-94 & 0750 & .01 & 3.1 & 11.5 & 864 & 3.3 & 0 & 760 & 3.1 \\
\hline 132 & Stoystown & 07-13-94 & 1300 & .01 & 4.3 & 19.0 & 1,100 & 5.9 & 8 & 1,200 & 2.2 \\
\hline 133 & Stoystown & 07-13-94 & 1400 & $<.01$ & .4 & 15.0 & 1,720 & 3.8 & 0 & 1,990 & 7.8 \\
\hline 134 & Stoystown & 07-13-94 & 1450 & .01 & 4.0 & 18.5 & 1,140 & 4.1 & 0 & 1,310 & $<1.0$ \\
\hline 135 & Stoystown & 07-13-94 & 1730 & .13 & 60 & 11.5 & 731 & 6.6 & 176 & 668 & 15 \\
\hline 136 & Hooversville & 07-14-94 & 0750 & .02 & 7.5 & 10.0 & 288 & 6.6 & 86 & 234 & 5.6 \\
\hline 137 & Hooversville & 07-14-94 & 0840 & .40 & 180 & 9.5 & 360 & 5.3 & 6 & 352 & 5.5 \\
\hline 138 & Geistown & $07-21-94$ & 1010 & $<.01$ & 1.6 & 18.0 & 1,280 & 2.7 & 0 & 1,360 & 5.3 \\
\hline 139 & Geistown & 07-21-94 & 1100 & .03 & 13 & 16.5 & 2,520 & 2.6 & 0 & 2,600 & 4.6 \\
\hline 140 & Geistown & $07-21-94$ & 1130 & .06 & 27 & 16.5 & 3,090 & 2.5 & 0 & 3,270 & 5.6 \\
\hline \multirow{3}{*}{141} & & 11-17-94 & 1500 & .04 & 20 & 7.5 & 2,600 & 3.0 & 0 & 3,640 & $<1.0$ \\
\hline & Geistown & $07-21-94$ & 1230 & .11 & 48 & 21.5 & 3,820 & 2.7 & 0 & 5,520 & 4.0 \\
\hline & & $11-17-94$ & 1420 & .04 & 18 & 9.0 & 3,360 & 2.9 & 0 & 5,250 & $<1.0$ \\
\hline 142 & Geistown & $07-21-94$ & 1300 & .01 & 2.5 & 22.0 & 4,280 & 2.2 & 0 & 5,530 & 8.1 \\
\hline 143 & New Baltimore & 08-01-94 & 1010 & $<.01$ & 1.4 & 13.5 & 1,650 & 3.9 & 0 & 2,310 & 8.4 \\
\hline
\end{tabular}




\begin{tabular}{|c|c|c|c|c|c|c|c|c|c|c|c|}
\hline Date & $\begin{array}{l}\text { Sulfate, } \\
\text { dissolved } \\
(\mathrm{mg} / \mathrm{L} \\
\left.\text { as } \mathrm{SO}_{4}\right)\end{array}$ & $\begin{array}{c}\text { Fluoride, } \\
\text { total } \\
\text { (mg/L as F) }\end{array}$ & $\begin{array}{l}\text { Iron, total } \\
\text { recoverable } \\
(\mu \mathrm{g} / \mathrm{L} \\
\text { as Fe }\end{array}$ & $\begin{array}{c}\text { Iron, } \\
\text { dissolved } \\
(\mu \mathrm{g} / \mathrm{L} \\
\text { as Fe }\end{array}$ & $\begin{array}{c}\text { Iron, } \\
\text { ferrous, } \\
\text { dissolved } \\
(\mu \mathrm{g} / \mathrm{L} \\
\text { as } \mathrm{Fe}\end{array}$ & $\begin{array}{c}\text { Manganese, } \\
\text { total } \\
\text { recoverable } \\
(\mu \mathrm{g} / \mathrm{L} \\
\text { as } \mathrm{Mn}\end{array}$ & $\begin{array}{c}\text { Manganese, } \\
\text { dissolved } \\
(\mu \mathrm{g} / \mathrm{L} \\
\text { as } \mathrm{Mn})\end{array}$ & $\begin{array}{c}\text { Aluminum, } \\
\text { total } \\
\text { recoverable } \\
(\mu \mathrm{g} / \mathrm{L} \\
\text { as Al) }\end{array}$ & $\begin{array}{c}\text { Aluminum, } \\
\text { dissolved } \\
(\mu \mathrm{g} / \mathrm{L} \\
\text { as Al) }\end{array}$ & $\begin{array}{c}\text { Acidity, } \\
\text { total } \\
\text { heated } \\
(\mathrm{mg} / \mathrm{L} \text { as } \\
\left.\mathrm{CaCO}_{3}\right)\end{array}$ & $\begin{array}{c}\text { Acidity, } \\
\text { mineral } \\
\text { (methyl } \\
\text { orange) } \\
(\mathrm{mg} / \mathrm{L} \mathrm{as} \\
\left.\mathrm{CaCO}_{3}\right)\end{array}$ \\
\hline $05-25-94$ & 780 & 0.2 & 1,700 & 1,700 & 170 & 1,800 & 1,800 & 4,800 & 4,700 & 94 & 40 \\
\hline $05-25-94$ & 81 & $<.2$ & 60 & 48 & -- & 440 & 420 & 330 & 310 & 12 & -- \\
\hline $05-25-94$ & 1,100 & .3 & 1,500 & 1,500 & 250 & 4,900 & 4,900 & 6,500 & 6,500 & 92 & 26 \\
\hline $11-17-94$ & 1,900 & .7 & 12,000 & 12,000 & 920 & 20,000 & 20,000 & 28,000 & 27,000 & 350 & 122 \\
\hline $05-25-94$ & 1,600 & .4 & 6,800 & 6,500 & 500 & 14,000 & 14,000 & 14,000 & 13,000 & 194 & 72 \\
\hline $11-17-94$ & 1,800 & .7 & 9,300 & 9,200 & 840 & 22,000 & 20,000 & 24,000 & 24,000 & 314 & 108 \\
\hline $05-26-94$ & 240 & $<.2$ & 9,700 & 7,800 & -- & 4,000 & 3,700 & 1,000 & 930 & 34 & 12 \\
\hline $06-07-94$ & 5.1 & $<.2$ & 2,000 & 640 & -- & 630 & 570 & $<130$ & $<130$ & 0 & -- \\
\hline 06-14-94 & 330 & $<.2$ & 490 & 22 & -- & 280 & 230 & 670 & 260 & 19 & -- \\
\hline 06-14-94 & 430 & $<.2$ & 90 & 45 & -- & 44 & 41 & 200 & $<130$ & 0 & -- \\
\hline 06-14-94 & 650 & $<.2$ & 39,000 & 39,000 & -- & 2,100 & 2,100 & 170 & 170 & 62 & -- \\
\hline $06-14-94$ & 780 & $<.2$ & 30,000 & 28,000 & -- & 2,300 & 2,300 & 3,800 & 3,500 & 100 & -- \\
\hline $11-21-94$ & 1,200 & $<.2$ & 45,000 & 39,000 & 43,000 & 3,000 & 2,700 & 4,800 & 4,200 & 102 & -- \\
\hline $06-20-94$ & 600 & .4 & 530 & 510 & 410 & 6,500 & 6,300 & 8,700 & 8,500 & 82 & 19 \\
\hline $06-22-94$ & 920 & .4 & 380 & 330 & 150 & 5,200 & 5,000 & 8,300 & 8,000 & 74 & 12 \\
\hline $06-22-94$ & 1,000 & .4 & 450 & 410 & -- & 6,100 & 6,000 & 9,900 & 9,600 & 92 & 18 \\
\hline $06-22-94$ & 1,200 & .5 & 640 & 640 & -- & 7,200 & 7,200 & 8,800 & 8,800 & 90 & 14 \\
\hline $06-22-94$ & 1,200 & .6 & 990 & 950 & 400 & 11,000 & 11,000 & 8,000 & 8,000 & 92 & 15 \\
\hline $06-22-94$ & 990 & .5 & 870 & 870 & 370 & 6,600 & 6,600 & 6,400 & 6,400 & 76 & 13 \\
\hline $06-27-94$ & 2,400 & .9 & 33,000 & 30,000 & 24,000 & 68,000 & 64,000 & 120,000 & 110,000 & 934 & 248 \\
\hline $06-27-94$ & 1,900 & .7 & 60,000 & 54,000 & 32,000 & 33,000 & 33,000 & 67,000 & 65,000 & 734 & 260 \\
\hline $06-27-94$ & 74 & $<.2$ & 150 & 56 & -- & 330 & 310 & 180 & $<130$ & 32 & -- \\
\hline $06-27-94$ & 350 & $<.2$ & 5,700 & 5,400 & 840 & 2,100 & 1,900 & 770 & 770 & 112 & 60 \\
\hline 06-28-94 & 400 & .3 & 760 & 71 & -- & 940 & 880 & 2,400 & 330 & 7.6 & -- \\
\hline 06-28-94 & 6,100 & 2.0 & 690,000 & 650,000 & 230,000 & 37,000 & 36,000 & 320,000 & 310,000 & 3,620 & 1,580 \\
\hline 06-28-94 & 420 & $<.2$ & 170 & 85 & -- & 50 & 50 & 190 & $<130$ & .0 & -- \\
\hline 07-06-94 & 3,000 & 1.1 & 47,000 & 47,000 & 1,500 & 53,000 & 53,000 & 89,000 & 89,000 & 866 & -- \\
\hline $11-17-94$ & 1,800 & .7 & 12,000 & 11,000 & 1,200 & 27,000 & 26,000 & 54,000 & 52,000 & 512 & 118 \\
\hline 07-06-94 & 3,200 & 1.4 & 130,000 & 130,000 & 6,900 & 66,000 & 65,000 & 87,000 & 86,000 & 1,176 & -- \\
\hline $11-17-94$ & 1,800 & 1.0 & 83,000 & 83,000 & 5,200 & 44,000 & 44,000 & 57,000 & 57,000 & 908 & 338 \\
\hline 07-06-94 & 810 & .5 & 3,900 & 3,900 & 770 & 24,000 & 24,000 & 28,000 & 28,000 & 276 & -- \\
\hline 07-06-94 & 1,600 & 1.6 & 110,000 & 110,000 & 27,000 & 32,000 & 32,000 & 1,200 & 1,200 & 486 & -- \\
\hline $07-06-94$ & 1,000 & .4 & 230 & 220 & 200 & 11,000 & 11,000 & 6,400 & 6,400 & 66 & -- \\
\hline 07-06-94 & 1,500 & .5 & 810 & 880 & 430 & 18,000 & 18,000 & 8,600 & 8,600 & 92 & -- \\
\hline 07-07-94 & 640 & .2 & 80 & 60 & 60 & 1,600 & 1,500 & 2,500 & 2,500 & 30 & -- \\
\hline 07-07-94 & 420 & $<.2$ & 25,000 & 15,000 & 15,000 & 4,900 & 4,900 & 1,500 & 1,500 & 62 & -- \\
\hline 07-13-94 & 740 & $<.2$ & 8,600 & 8,600 & -- & 8,500 & 8,400 & 250 & 180 & 58 & -- \\
\hline 07-13-94 & 1,100 & .4 & 470 & 420 & 250 & 16,000 & 16,000 & 11,000 & 11,000 & 152 & 14 \\
\hline 07-13-94 & 810 & $<.2$ & 510 & 430 & 260 & 9,600 & 9,600 & 2,200 & 2,200 & 72 & -- \\
\hline 07-13-94 & 250 & $<.2$ & 1,200 & 840 & -- & 140 & 140 & $<130$ & $<130$ & 0 & -- \\
\hline 07-14-94 & 58 & $<.2$ & 1,800 & 1,300 & -- & 170 & 160 & $<130$ & $<130$ & 0 & -- \\
\hline 07-14-94 & 170 & .2 & 50 & 17 & -- & 310 & 300 & 1,300 & 1,000 & 30 & -- \\
\hline 07-21-94 & 870 & .3 & 17,000 & 17,000 & 1,700 & 23,000 & 23,000 & 11,000 & 11,000 & 214 & 126 \\
\hline 07-21-94 & 1,600 & .4 & 59,000 & 59,000 & 2,500 & 39,000 & 39,000 & 20,000 & 20,000 & 468 & 306 \\
\hline 07-21-94 & 2,000 & .5 & 70,000 & 70,000 & 3,300 & 48,000 & 48,000 & 33,000 & 32,000 & 684 & 388 \\
\hline 11-17-94 & 1,500 & .5 & 140,000 & 140,000 & 3,700 & 39,000 & 39,000 & 23,000 & 23,000 & 782 & 396 \\
\hline $07-21-94$ & 1,500 & 1.9 & 210,000 & 200,000 & 110,000 & 110,000 & 110,000 & 75,000 & 74,000 & 1,304 & 550 \\
\hline $11-17-94$ & 2,900 & 1.4 & 230,000 & 230,000 & 190,000 & 72,000 & 71,000 & 63,000 & 63,000 & 1,332 & 336 \\
\hline 07-21-94 & 3,400 & 1.3 & 140,000 & 140,000 & 5,900 & 93,000 & 93,000 & 49,000 & 49,000 & 1,120 & 700 \\
\hline 08-01-94 & 1,300 & 1.6 & 390 & 350 & 380 & 51,000 & 51,000 & 37,000 & 37,000 & 258 & -- \\
\hline
\end{tabular}




\begin{tabular}{|c|c|c|c|c|c|c|c|c|c|c|c|}
\hline $\begin{array}{c}\text { Site } \\
\text { number }\end{array}$ & $\begin{array}{c}\text { Local } \\
\text { identifier } \\
\text { (Topographic } \\
\text { quadrangle) }\end{array}$ & Date & Time & $\begin{array}{l}\text { Discharge, } \\
\text { instan- } \\
\text { taneous } \\
\left(\mathrm{ft}^{3} / \mathrm{s}\right)\end{array}$ & $\begin{array}{c}\text { Flow rate, } \\
\text { instan- } \\
\text { taneous } \\
\text { (gal/min) }\end{array}$ & $\begin{array}{l}\text { Temper- } \\
\text { ature, } \\
\text { water } \\
\left({ }^{\circ} \mathrm{C}\right)\end{array}$ & $\begin{array}{c}\text { Specific } \\
\text { conduc- } \\
\text { tance } \\
(\mu \mathrm{S} / \mathrm{cm})\end{array}$ & $\begin{array}{l}\mathrm{pH} \text {, water } \\
\text { whole } \\
\text { field } \\
\text { (standard } \\
\text { units) }\end{array}$ & $\begin{array}{c}\text { Alkalinity, } \\
\text { water } \\
(\mathrm{mg} / \mathrm{L} \text { as } \\
\mathrm{CaCO}_{3} \text { ) }\end{array}$ & $\begin{array}{c}\text { Residue at } \\
105^{\circ} \mathrm{C} \text {, } \\
\text { dissolved } \\
\text { (mg/L) }\end{array}$ & $\begin{array}{c}\text { Carbon, } \\
\text { inorganic, } \\
\text { total } \\
(\mathrm{mg} / \mathrm{L} \\
\text { as C) }\end{array}$ \\
\hline 144 & Stoystown & 08-01-94 & 1150 & .41 & 185 & 11.0 & 1,590 & 6.0 & 100 & 1,850 & 9.4 \\
\hline 145 & Central City & 08-01-94 & 1415 & .01 & 4.9 & 13.0 & 2,600 & 6.2 & 140 & 3,410 & 12 \\
\hline 146 & Stoystown & 08-01-94 & 1050 & $<.01$ & 1.1 & 25.0 & 1,030 & 6.7 & 38 & 956 & 6.7 \\
\hline 147 & Johnstown & 08-10-94 & 0920 & $<.01$ & .5 & 21.0 & 1,350 & 6.8 & 88 & 1,300 & 4.6 \\
\hline 148 & Johnstown & 08-10-94 & 1010 & $<.01$ & .2 & 21.5 & 1,480 & 6.3 & 70 & 1,770 & 3.0 \\
\hline \multirow[t]{2}{*}{149} & Johnstown & 08-10-94 & 1115 & .69 & 310 & 14.0 & 2,480 & 5.7 & 48 & 2,840 & 3.8 \\
\hline & & $11-21-94$ & 1000 & 2.0 & 884 & 13.0 & 2,840 & 5.7 & 66 & 3,210 & 31 \\
\hline 150 & Johnstown & 08-10-94 & 1245 & $<.01$ & 1.0 & 20.5 & 2,390 & 7.3 & 232 & 2,360 & 6.4 \\
\hline 151 & Stoystown & $07-21-92$ & 1145 & .28 & 126 & 10.5 & 725 & 6.5 & 190 & 640 & 44 \\
\hline 152 & Stoystown & $07-21-92$ & 1230 & .64 & 289 & 10.5 & 870 & 6.5 & 96 & 792 & 30 \\
\hline 153 & Stoystown & $07-21-92$ & 1320 & $<.01$ & .3 & 9.5 & 700 & 6.3 & 26 & 676 & 12 \\
\hline 154 & Stoystown & $07-21-92$ & 1435 & .06 & 28 & 17.0 & 1,640 & 3.5 & 0 & 1,170 & 1.2 \\
\hline 155 & Stoystown & $07-21-92$ & 1600 & .04 & 20 & 14.0 & 2,200 & 3.2 & 0 & 2,390 & 1.1 \\
\hline \multirow[t]{2}{*}{156} & Stoystown & $07-22-92$ & 1130 & .08 & 36 & 12.5 & 2,200 & 3.5 & 0 & 2,210 & 31 \\
\hline & & $08-17-93$ & 1135 & .10 & 45 & 14.0 & 2,220 & 3.8 & 0 & 2,420 & 14 \\
\hline 157 & Stoystown & $07-22-92$ & 1305 & .01 & 3.6 & 15.5 & 2,200 & 6.7 & 370 & 3,090 & 94 \\
\hline 158 & Stoystown & $07-22-92$ & 1410 & $<.01$ & .5 & 15.5 & 4,020 & 3.8 & 0 & 6,000 & 20 \\
\hline 159 & Stoystown & $07-22-92$ & 1545 & .01 & 2.3 & 15.5 & 1,210 & 4.6 & 3 & 1,330 & 4.4 \\
\hline \multirow[t]{3}{*}{160} & Stoystown & $07-22-92$ & 1545 & .38 & 171 & 10.5 & 1,830 & 3.1 & 0 & 1,460 & 11 \\
\hline & & 08-17-93 & 1220 & .24 & 110 & 11.0 & 1,810 & 3.4 & 0 & 1,670 & 9.7 \\
\hline & & 05-09-94 & 1635 & .60 & 272 & 10.5 & 1,370 & 2.9 & 0 & 1,180 & 10 \\
\hline 161 & Stoystown & $07-22-92$ & 1620 & .04 & 20 & 15.5 & 1,380 & 3.2 & 0 & 1,160 & $<1.0$ \\
\hline 162 & Stoystown & $07-23-92$ & 0945 & .01 & 5.0 & 16.0 & 2,170 & 3.1 & 0 & 2,170 & $<1.0$ \\
\hline 163 & Stoystown & $07-23-92$ & 1025 & $<.01$ & 2.0 & 16.0 & 1,990 & 3.0 & 0 & 1,860 & 2.7 \\
\hline 164 & Hooversville & 07-23-92 & 1130 & .22 & 97 & 11.0 & 1,680 & 2.8 & 0 & 1,500 & 2.9 \\
\hline \multirow{5}{*}{165} & & 08-18-93 & 1315 & .20 & 90 & 11.0 & 2,220 & 3.4 & 0 & 2,370 & 6.8 \\
\hline & & 05-03-94 & 1710 & 1.2 & 540 & 10.5 & 1,640 & 2.8 & 0 & 1,530 & 7.4 \\
\hline & Johnstown & $07-23-92$ & 1500 & .03 & 18 & 20.0 & 3,090 & 2.7 & 0 & 5,020 & 1.2 \\
\hline & & 09-01-93 & 1400 & .07 & 33 & 19.0 & 4,910 & 2.5 & 0 & 9,650 & $<1.0$ \\
\hline & & 04-19-94 & 1600 & .07 & 33 & 12.5 & 4,980 & 2.4 & 0 & 5,680 & 14 \\
\hline \multirow[t]{3}{*}{166} & Hooversville & $07-24-92$ & 0940 & .03 & 13 & 12.0 & 2,270 & 2.7 & 0 & 2,420 & 1.6 \\
\hline & & 09-01-93 & 1000 & .01 & 4.0 & 16.0 & 2,520 & 2.6 & 0 & 2,660 & $<1.0$ \\
\hline & & 05-09-94 & 1100 & .17 & 77 & 10.5 & 1,960 & 2.5 & 0 & 1,710 & 5.9 \\
\hline 167 & Berlin & 08-03-92 & 1025 & .03 & 5.0 & 12.0 & 665 & 3.5 & 0 & 574 & 4.8 \\
\hline \multirow[t]{2}{*}{168} & New Baltimore Qua & 08-03-92 & -- & .01 & 2.3 & 12.5 & 1,180 & 6.0 & 38 & 1,070 & 18 \\
\hline & & 08-03-92 & 1110 & .01 & 2.3 & 12.5 & 1,180 & 7.0 & 38 & 1,070 & 18 \\
\hline 169 & New Baltimore Qua & 08-03-92 & 1255 & .03 & 15 & 10.0 & 1,210 & 6.0 & 28 & 1,250 & 16 \\
\hline 170 & Berlin & 08-03-92 & 1500 & .32 & 142 & 12.0 & 1,790 & 6.2 & 130 & 2,040 & 17 \\
\hline 171 & Boswell & $05-11-94$ & 1200 & .15 & 69 & 14.0 & 366 & 6.6 & 19 & 288 & 5.4 \\
\hline \multirow[t]{2}{*}{172} & Boswell & 08-05-92 & 1000 & .07 & 30 & 14.0 & 1,710 & 2.8 & 0 & 1,640 & $<1.0$ \\
\hline & & 09-02-93 & 0830 & $<.01$ & $<.1$ & 18.0 & 1,460 & 2.9 & 0 & 1,070 & 8.1 \\
\hline 173 & Boswell & 08-05-92 & 1115 & 1.0 & 470 & 10.5 & 1,460 & 6.2 & 100 & 1,180 & 23 \\
\hline 174 & Boswell & 08-05-92 & 1155 & .02 & 7.5 & 13.0 & 1,450 & 5.0 & 12 & 1,200 & 13 \\
\hline 175 & Boswell & 08-05-92 & 1315 & .01 & 5.0 & 15.5 & 1,060 & 3.2 & 0 & 708 & 5.7 \\
\hline \multirow[t]{3}{*}{176} & Boswell & 08-05-92 & 1530 & .73 & 330 & 11.0 & 890 & 5.9 & 34 & 760 & 15 \\
\hline & & 09-02-93 & 0920 & .09 & 39 & 11.0 & 967 & 5.9 & 28 & 988 & 17 \\
\hline & & 05-10-94 & 0820 & .22 & 101 & 11.0 & 1,000 & 6.2 & 20 & 1,020 & 14 \\
\hline 177 & Hooversville & 08-06-92 & 0920 & .02 & 7.0 & 11.5 & 2,000 & 2.7 & 0 & 1,750 & 1.9 \\
\hline \multirow[t]{2}{*}{178} & Hooversville & 08-06-92 & 0940 & 3.6 & 1,620 & 12.5 & 1,350 & 5.9 & 160 & 1,070 & 26 \\
\hline & & 09-08-93 & 1820 & 2.1 & 962 & 12.5 & 1,320 & 6.5 & 162 & 1,120 & 30 \\
\hline
\end{tabular}




\begin{tabular}{|c|c|c|c|c|c|c|c|c|c|c|c|}
\hline Date & $\begin{array}{c}\text { Sulfate, } \\
\text { dissolved } \\
(\mathrm{mg} / \mathrm{L} \\
{\left.\text { as } \mathrm{SO}_{4}\right)}^{2}\end{array}$ & $\begin{array}{l}\text { Fluoride, } \\
\text { total } \\
\text { (mg/L as F) }\end{array}$ & $\begin{array}{c}\text { Iron, total } \\
\text { recoverable } \\
(\mu \mathrm{g} / \mathrm{L} \\
\text { as Fe }\end{array}$ & $\begin{array}{c}\text { Iron, } \\
\text { dissolved } \\
(\mu \mathrm{g} / \mathrm{L} \\
\text { as Fe }\end{array}$ & $\begin{array}{c}\text { Iron, } \\
\text { ferrous, } \\
\text { dissolved } \\
(\mu \mathrm{g} / \mathrm{L} \\
\text { as Fe }\end{array}$ & $\begin{array}{c}\text { Manganese, } \\
\text { total } \\
\text { recoverable } \\
(\mu \mathrm{g} / \mathrm{L} \\
\text { as } \mathrm{Mn}\end{array}$ & $\begin{array}{c}\text { Manganese, } \\
\text { dissolved } \\
(\mu \mathrm{g} / \mathrm{L} \\
\text { as } \mathrm{Mn})\end{array}$ & $\begin{array}{c}\text { Aluminum, } \\
\text { total } \\
\text { recoverable } \\
(\mu \mathrm{g} / \mathrm{L} \\
\text { as Al) }\end{array}$ & $\begin{array}{c}\text { Aluminum, } \\
\text { dissolved } \\
(\mu \mathrm{g} / \mathrm{L} \\
\text { as Al) }\end{array}$ & $\begin{array}{c}\text { Acidity, } \\
\text { total } \\
\text { heated } \\
(\mathrm{mg} / \mathrm{L} \text { as } \\
\left.\mathrm{CaCO}_{3}\right)\end{array}$ & $\begin{array}{l}\text { Acidity, } \\
\text { mineral } \\
\text { (methyl } \\
\text { orange) } \\
(\mathrm{mg} / \mathrm{L} \text { as } \\
\left.\mathrm{CaCO}_{3}\right)\end{array}$ \\
\hline 08-01-94 & 1,000 & $<0.2$ & 13,000 & 12,000 & -- & 35,000 & 35,000 & 150 & $<130$ & 0 & -- \\
\hline 08-01-94 & 2,000 & $<.2$ & 70 & 29 & -- & 280 & 260 & 170 & 160 & 0 & -- \\
\hline 08-01-94 & 600 & .4 & 1,600 & 79 & -- & 120 & 120 & 300 & 140 & 0 & -- \\
\hline 08-10-94 & 610 & .3 & 81,000 & 60,000 & -- & 1,600 & 1,200 & 260 & $<130$ & 0 & -- \\
\hline 08-10-94 & 1,100 & .5 & 100,000 & 98,000 & -- & 2,000 & 2,000 & 390 & $<130$ & 92 & -- \\
\hline 08-10-94 & 1,600 & $<.2$ & 300,000 & 300,000 & -- & 3,000 & 2,900 & 790 & 580 & 540 & -- \\
\hline $11-21-94$ & 3,100 & $<.2$ & 390,000 & 330,000 & -- & 4,400 & 4,100 & 650 & 400 & 634 & -- \\
\hline 08-10-94 & 1,300 & .4 & 6,400 & 1,200 & -- & 1,200 & 1,100 & 890 & 150 & 0 & -- \\
\hline $07-21-92$ & 190 & $<.2$ & 3,000 & 2,000 & -- & 260 & 240 & $<100$ & $<100$ & 0 & 0 \\
\hline $07-21-92$ & 360 & $<.2$ & 40 & 20 & -- & 100 & 100 & 200 & $<100$ & 0 & 0 \\
\hline 07-21-92 & 330 & $<.2$ & 230 & $<10$ & -- & 320 & 300 & 2,600 & $<100$ & 0 & 0 \\
\hline 07-21-92 & 690 & $<.2$ & 2,200 & 2,200 & -- & 8,000 & 8,000 & 700 & 700 & 50 & 15 \\
\hline 07-21-92 & 1,400 & 1.2 & 3,900 & 3,900 & -- & 5,000 & 5,000 & 13,000 & 13,000 & 150 & 44 \\
\hline 07-22-92 & 1,400 & .8 & 4,400 & 4,400 & -- & 2,800 & 2,800 & 12,000 & 12,000 & 100 & 14 \\
\hline 08-17-93 & 1,400 & .7 & 3,100 & 2,800 & 660 & 2,500 & 2,500 & 9,200 & 9,200 & 98 & 10 \\
\hline 07-22-92 & 1,700 & $<.2$ & 3,000 & 2,500 & -- & 17,000 & 16,000 & 300 & 300 & 0 & 0 \\
\hline 07-22-92 & 3,600 & 1.7 & 200,000 & 200,000 & -- & 120,000 & 120,000 & 74,000 & 73,000 & 850 & 9 \\
\hline $07-22-92$ & 770 & .5 & 3,100 & 2,900 & -- & 24,000 & 24,000 & 13,000 & 13,000 & 92 & 0 \\
\hline $07-22-92$ & 960 & $<.2$ & 5,900 & 5,700 & -- & 13,000 & 13,000 & 7,200 & 7,100 & 120 & 54 \\
\hline 08-17-93 & 1,100 & $<.2$ & 6,100 & 6,100 & 1,000 & 12,000 & 12,000 & 7,300 & 7,100 & 124 & 48 \\
\hline 05-09-94 & 900 & $<.2$ & 4,400 & 4,400 & 1,000 & 11,000 & 11,000 & 5,600 & 5,600 & 104 & 30 \\
\hline 07-22-92 & 770 & $<.2$ & 3,600 & 3,500 & -- & 11,000 & 11,000 & 2,600 & 2,600 & 82 & 40 \\
\hline 07-23-92 & 1,400 & .8 & 2,500 & 2,400 & -- & 17,000 & 17,000 & 12,000 & 12,000 & 130 & 42 \\
\hline 07-23-92 & 1,200 & .3 & 7,100 & 7,100 & -- & 21,000 & 21,000 & 7,000 & 7,000 & 140 & 64 \\
\hline 07-23-92 & 840 & .8 & 26,000 & 25,000 & -- & 5,100 & 4,900 & 17,000 & 16,000 & 260 & 130 \\
\hline 08-18-93 & 1,400 & 1.0 & 64,000 & 63,000 & 1,000 & 6,600 & 6,600 & 39,000 & 39,000 & 504 & 242 \\
\hline 05-03-94 & 1,000 & .6 & 37,000 & 36,000 & 680 & 5,000 & 5,000 & 23,000 & 23,000 & 338 & 160 \\
\hline 07-23-92 & 2,200 & .8 & 320,000 & 300,000 & -- & 5,700 & 5,700 & 97,000 & 97,000 & 1,600 & 770 \\
\hline 09-01-93 & 5,800 & 1 & 760,000 & 750,000 & 300,000 & 8,600 & 8,600 & 210,000 & 210,000 & 2,760 & 1,190 \\
\hline 04-19-94 & 4,700 & 1.0 & 630,000 & 570,000 & 440,000 & 6,600 & 6,000 & 170,000 & 150,000 & 2,342 & 628 \\
\hline 07-24-92 & 1,500 & .4 & 150,000 & 150,000 & -- & 1,900 & 1,900 & 45,000 & 45,000 & 820 & 440 \\
\hline 09-01-93 & 2,100 & .4 & 140,000 & 130,000 & 130,000 & 2,400 & 2,300 & 58,000 & 58,000 & 806 & 436 \\
\hline 05-09-94 & 1,100 & -- & 120,000 & 120,000 & 44,000 & 1,500 & 1,500 & 34,000 & 34,000 & 596 & 332 \\
\hline 08-03-92 & 280 & .3 & 1,700 & 940 & -- & 6,600 & 6,600 & 7,300 & 7,200 & 76 & 17 \\
\hline 08-03-92 & 670 & $<.2$ & 33,000 & 21,000 & -- & 3,400 & 2,300 & $<130$ & $<130$ & 19 & -- \\
\hline 08-03-92 & 670 & $<.2$ & 33,000 & 21,000 & -- & 3,400 & 2,300 & $<130$ & $<130$ & 19 & -- \\
\hline 08-03-92 & 720 & .2 & 74,000 & 73,000 & -- & 12,000 & 12,000 & 300 & 300 & 120 & 0 \\
\hline 08-03-92 & 1,000 & $<.2$ & 9,700 & 9200 & -- & 35,000 & 35,000 & 300 & 200 & 0 & 0 \\
\hline 05-11-94 & 150 & $<.2$ & 950 & 570 & -- & 510 & 500 & 140 & $<130$ & 0 & -- \\
\hline 08-05-92 & 950 & .6 & 6,600 & 6,700 & -- & 14,000 & 14,000 & 24,000 & 24,000 & 260 & 70 \\
\hline 09-02-93 & 910 & .2 & 110,000 & 110,000 & 88,000 & 11,000 & 11,000 & 2,000 & 2,000 & 284 & 110 \\
\hline 08-05-92 & 810 & $<.2$ & 34,000 & 34,000 & -- & 4,400 & 4,400 & $<100$ & 200 & 0 & 0 \\
\hline 08-05-92 & 930 & $<.2$ & 180,000 & 180,000 & -- & 13,000 & 13,000 & 1,000 & 800 & 340 & 0 \\
\hline 08-05-92 & 480 & .3 & 37,000 & 37,000 & -- & 11,000 & 11,000 & 5,400 & 5,300 & 120 & 68 \\
\hline 08-05-92 & 450 & $<.2$ & 110,000 & 110,000 & -- & 6,100 & 6,100 & $<100$ & $<100$ & 162 & 0 \\
\hline 09-02-93 & 620 & $<.2$ & 120,000 & 120,000 & 120,000 & 7,300 & 7,300 & $<130$ & $<130$ & 186 & -- \\
\hline 05-10-94 & 640 & $<.2$ & 130,000 & 130,000 & -- & 8,100 & 7,800 & $<130$ & $<130$ & 232 & -- \\
\hline 08-06-92 & 1,000 & .5 & 59,000 & 58,000 & -- & 1,700 & 1,700 & 40,000 & 39,000 & 520 & 240 \\
\hline 08-06-92 & 640 & $<.2$ & 17,000 & 1,800 & -- & 620 & 620 & 8,500 & 200 & 0 & 0 \\
\hline 09-08-93 & 610 & $<.2$ & 3,500 & 1,700 & -- & 480 & 480 & 1,000 & $<130$ & 0 & -- \\
\hline
\end{tabular}




\begin{tabular}{|c|c|c|c|c|c|c|c|c|c|c|c|}
\hline $\begin{array}{c}\text { Site } \\
\text { number }\end{array}$ & $\begin{array}{c}\text { Local } \\
\text { identifier } \\
\text { (Topographic } \\
\text { quadrangle) }\end{array}$ & Date & Time & $\begin{array}{l}\text { Discharge, } \\
\text { instan- } \\
\text { taneous } \\
\left(\mathrm{ft}^{3} / \mathrm{s}\right)\end{array}$ & $\begin{array}{c}\text { Flow rate, } \\
\text { instan- } \\
\text { taneous } \\
\text { (gal/min) }\end{array}$ & $\begin{array}{l}\text { Temper- } \\
\text { ature, } \\
\text { water } \\
\left({ }^{\circ} \mathrm{C}\right)\end{array}$ & $\begin{array}{c}\text { Specific } \\
\text { conduc- } \\
\text { tance } \\
(\mu \mathrm{S} / \mathrm{cm})\end{array}$ & $\begin{array}{l}\mathrm{pH} \text {, water } \\
\text { whole } \\
\text { field } \\
\text { (standard } \\
\text { units) }\end{array}$ & $\begin{array}{l}\text { Alkalinity, } \\
\text { water } \\
(\mathrm{mg} / \mathrm{L} \text { as } \\
\left.\mathrm{CaCO}_{3}\right)\end{array}$ & $\begin{array}{c}\text { Residue at } \\
105^{\circ} \mathrm{C} \text {, } \\
\text { dissolved } \\
\text { (mg/L) }\end{array}$ & $\begin{array}{c}\text { Carbon, } \\
\text { inorganic, } \\
\text { total } \\
(\mathrm{mg} / \mathrm{L} \\
\text { as C) }\end{array}$ \\
\hline 179 & Hooversville & 05-11-94 & 1050 & .02 & 7.5 & 10.5 & 1,180 & 3.8 & 0 & 1,020 & 3.6 \\
\hline \multirow[t]{3}{*}{180} & Hooversville & 08-06-92 & 1115 & .06 & 25 & 11.0 & 2,350 & 2.7 & 0 & 2,420 & 3.1 \\
\hline & & 09-01-93 & 1100 & .07 & 30 & 11.0 & 2,590 & 2.4 & 0 & 2,480 & $<1.0$ \\
\hline & & 05-09-94 & 1145 & .38 & 171 & 11.0 & 1,630 & 2.3 & 0 & 1,350 & 3.3 \\
\hline 181 & Hooversville & 07-14-93 & 1535 & .01 & 5.0 & 8.5 & 1,220 & 3.3 & 0 & 1,110 & $<1.0$ \\
\hline 182 & Ligonier & 07-14-93 & 1730 & $<.01$ & 1.0 & 15.0 & 232 & 5.2 & 16 & 160 & 8.3 \\
\hline 183 & Ligonier & 07-14-93 & 1740 & .01 & 3.0 & 17.5 & 353 & 4.2 & 0 & 210 & 1.7 \\
\hline \multirow[t]{2}{*}{184} & Windber & 07-15-93 & 0850 & .10 & 45 & 13.5 & 2,700 & 2.8 & 0 & 2790 & 18 \\
\hline & & 04-19-94 & 1210 & .17 & 75 & 13.5 & 2,710 & 2.5 & 0 & 2,490 & 23 \\
\hline 185 & Windber & 07-15-93 & 0930 & $<.01$ & 1.9 & 18.0 & 3,420 & 2.7 & 0 & 3,050 & 1.6 \\
\hline 186 & Johnstown & 08-10-94 & 1330 & .05 & 22 & 15.5 & 2,350 & 4.8 & 4 & 2,520 & 10 \\
\hline \multirow[t]{2}{*}{187} & Windber & 07-15-93 & 1140 & .08 & 36 & 11.5 & 1,740 & 2.4 & 0 & 1,630 & 1.6 \\
\hline & & 04-19-94 & 1430 & 1.0 & 470 & 11.5 & 1,940 & 2.5 & 0 & 1,390 & $<1.0$ \\
\hline \multirow[t]{2}{*}{188} & Windber & 07-15-93 & 1240 & .11 & 51 & 18.0 & 2,270 & 2.6 & 0 & 3,070 & 1.3 \\
\hline & & 04-19-94 & 1330 & .05 & 24 & 16.0 & 1,770 & 2.8 & 0 & 1,620 & $<1.0$ \\
\hline \multirow[t]{2}{*}{189} & Johnstown & 08-10-94 & 1500 & 1.2 & 539 & 12.0 & 1,200 & 3.4 & 0 & 1,080 & 3.9 \\
\hline & & $11-21-94$ & 1150 & 1.2 & 554 & 11.5 & 1,270 & 3.1 & 0 & 980 & 4.6 \\
\hline \multirow[t]{2}{*}{190} & Johnstown & 08-15-94 & 1000 & .13 & 60 & 12.0 & 2,130 & 3.1 & 0 & 2,380 & 30 \\
\hline & & $11-21-94$ & 1100 & .10 & 47 & 11.5 & 2,370 & 3.0 & 0 & 2,110 & 14 \\
\hline 191 & Johnstown & 08-15-94 & 1115 & .01 & 5.0 & 16.5 & 3,020 & 2.8 & 0 & 4,140 & 5.6 \\
\hline 192 & Johnstown & 08-15-94 & 1200 & $<.01$ & 2.1 & 15.0 & 3,120 & 3.3 & 0 & 4,280 & 20 \\
\hline 193 & Johnstown & 08-15-94 & 1245 & $<.01$ & 2.0 & 15.5 & 1,110 & 6.9 & 194 & 1,060 & 34 \\
\hline 194 & Johnstown & 08-15-94 & 1340 & .03 & 13 & 11.5 & 1,720 & 6.8 & 132 & 1,740 & 30 \\
\hline 195 & Johnstown & 08-15-94 & 1400 & .01 & 6.4 & 14.5 & 765 & 7.1 & 168 & 580 & 32 \\
\hline 196 & Johnstown & 08-15-94 & 1445 & .03 & 12 & 12.5 & 903 & 6.8 & 224 & 704 & 40 \\
\hline 197 & Johnstown & 08-15-94 & 1525 & .13 & 60 & 12.0 & 780 & 7.2 & 134 & 656 & 29 \\
\hline 198 & Johnstown & 08-15-94 & 1700 & $<.01$ & .3 & 17.5 & 1,020 & 4.0 & 0 & 968 & $<1.0$ \\
\hline 199 & Johnstown & 08-15-94 & 1800 & $<.01$ & .5 & 20.0 & 965 & 7.1 & 156 & 744 & 29 \\
\hline 200 & Windber & 08-22-94 & 1100 & .02 & 7.5 & 8.5 & 305 & 4.6 & 2 & 316 & 22 \\
\hline 201 & Windber & 08-22-94 & 1210 & $<.01$ & 1.6 & 11.5 & 258 & 4.2 & 0 & 260 & 18 \\
\hline 202 & Central City & 08-03-92 & 1200 & .12 & 54 & 14.0 & 2,090 & 6.1 & 138 & 2,350 & 18 \\
\hline 203 & Central City & 08-03-92 & 1540 & $<.01$ & $<.1$ & 15.0 & 3,100 & 3.8 & 0 & 4,100 & 16 \\
\hline \multirow[t]{2}{*}{204} & Hooversville & 08-04-92 & 1110 & .13 & 60 & 12.0 & 2,450 & 2.7 & 0 & 2,510 & 7.0 \\
\hline & & 05-09-94 & 0945 & .35 & 158 & 10.5 & 620 & 3.1 & 0 & 382 & 5.1 \\
\hline 205 & Hooversville & 08-04-92 & 1445 & .17 & 75 & 11.5 & 1,280 & 6.3 & 150 & 1,080 & 44 \\
\hline 206 & Hooversville & 10-11-94 & 1630 & .02 & 7.2 & 10.5 & 516 & 7.1 & 102 & 438 & 30 \\
\hline \multirow[t]{2}{*}{207} & Hooversville & 08-04-92 & 1600 & .49 & 221 & 11.0 & 907 & 4.9 & 2 & 926 & 3.9 \\
\hline & & 09-01-93 & 1210 & .35 & 156 & 11.0 & 975 & 4.2 & 1 & 918 & 2.7 \\
\hline \multirow[t]{3}{*}{208} & Somerset & 08-05-92 & 1050 & .83 & 374 & 11.0 & 694 & 6.2 & 0 & 2,270 & $<1.0$ \\
\hline & & 08-19-93 & 1115 & .55 & 248 & 11.5 & 730 & 6.0 & 56 & 606 & 30 \\
\hline & & 05-04-94 & 0820 & 1.1 & 475 & 10.0 & 625 & 5.8 & 40 & 464 & 24 \\
\hline 209 & Somerset & 08-05-92 & 1130 & .14 & 64 & 19.5 & 1,670 & 3.5 & 46 & 534 & 15 \\
\hline 210 & Berlin & 08-05-92 & 1535 & .22 & 97 & 10.5 & 872 & 5.8 & 38 & 746 & 19 \\
\hline 211 & Berlin & 08-06-92 & 1000 & 1.2 & 487 & 16.5 & 1090 & 6.6 & 84 & 744 & 17 \\
\hline 212 & New Baltimore & 07-07-93 & 0945 & .66 & 26 & 18.5 & 1,940 & 3.3 & 0 & 1,950 & $<1.0$ \\
\hline 213 & Central City & 07-07-93 & 1110 & .01 & 2.3 & 18.5 & 1,780 & 3.0 & 0 & 1,710 & 4.1 \\
\hline 214 & Windber & 07-07-93 & 1300 & .03 & 12 & 19.0 & 814 & 3.1 & 0 & 624 & $<1.0$ \\
\hline 215 & Windber & 07-07-93 & 1420 & .02 & 7.3 & 22.5 & 1,080 & 3.0 & 0 & 694 & $<1.0$ \\
\hline 216 & Windber & 07-07-93 & 1520 & .02 & 6.7 & 17.5 & 584 & 5.5 & 17 & 608 & $<1.0$ \\
\hline 217 & Windber & 07-08-93 & 0835 & .01 & 2.5 & 13.5 & 1,750 & 2.9 & 0 & 1,380 & 2.1 \\
\hline
\end{tabular}




\begin{tabular}{|c|c|c|c|c|c|c|c|c|c|c|c|}
\hline Date & $\begin{array}{c}\text { Sulfate, } \\
\text { dissolved } \\
(\mathrm{mg} / \mathrm{L} \\
\left.\text { as } \mathrm{SO}_{4}\right)\end{array}$ & $\begin{array}{l}\text { Fluoride, } \\
\text { total } \\
\text { (mg/L as F) }\end{array}$ & $\begin{array}{c}\text { Iron, total } \\
\text { recoverable } \\
(\mu \mathrm{g} / \mathrm{L} \\
\text { as Fe }\end{array}$ & $\begin{array}{c}\text { Iron, } \\
\text { dissolved } \\
(\mu \mathrm{g} / \mathrm{L} \\
\text { as Fe }\end{array}$ & $\begin{array}{c}\text { Iron, } \\
\text { ferrous, } \\
\text { dissolved } \\
(\mu \mathrm{g} / \mathrm{L} \\
\text { as Fe }\end{array}$ & $\begin{array}{c}\text { Manganese, } \\
\text { total } \\
\text { recoverable } \\
(\mu \mathrm{g} / \mathrm{L} \\
\text { as } \mathrm{Mn}\end{array}$ & $\begin{array}{c}\text { Manganese, } \\
\text { dissolved } \\
(\mu \mathrm{g} / \mathrm{L} \\
\text { as } \mathrm{Mn})\end{array}$ & $\begin{array}{c}\text { Aluminum, } \\
\text { total } \\
\text { recoverable } \\
(\mu \mathrm{g} / \mathrm{L} \\
\text { as Al) }\end{array}$ & $\begin{array}{c}\text { Aluminum, } \\
\text { dissolved } \\
(\mu \mathrm{g} / \mathrm{L} \\
\text { as Al) }\end{array}$ & $\begin{array}{c}\text { Acidity, } \\
\text { total } \\
\text { heated } \\
(\mathrm{mg} / \mathrm{L} \text { as } \\
\left.\mathrm{CaCO}_{3}\right)\end{array}$ & $\begin{array}{l}\text { Acidity, } \\
\text { mineral } \\
\text { (methyl } \\
\text { orange) } \\
(\mathrm{mg} / \mathrm{L} \text { as } \\
\left.\mathrm{CaCO}_{3}\right)\end{array}$ \\
\hline $05-11-94$ & 800 & $<0.2$ & 95,000 & 85,000 & 80,000 & 6,000 & 5,900 & 700 & 700 & 172 & 2 \\
\hline $08-06-92$ & 1,400 & .5 & 180,000 & 170,000 & -- & 2,000 & 2,000 & 44,000 & 43,000 & 820 & 470 \\
\hline 09-01-93 & 2,000 & .4 & 120,000 & 120,000 & 1,400 & 2,400 & 2,400 & 51,000 & 51,000 & 780 & 438 \\
\hline 05-09-94 & 960 & .3 & 80,000 & 79,000 & 900 & 1,100 & 1,100 & 25,000 & 25,000 & 476 & 276 \\
\hline $07-14-93$ & 900 & $<.2$ & 28,000 & 26,000 & 900 & 13,000 & 12,000 & 3,300 & 3,200 & 146 & 96 \\
\hline $07-14-93$ & 120 & $<.2$ & 15,000 & 14,000 & -- & 2,200 & 2,100 & $<130$ & $<130$ & 17 & -- \\
\hline $07-14-93$ & 210 & .2 & 1,400 & 1,100 & -- & 2,700 & 3,100 & 3,900 & 3,900 & 40 & 4 \\
\hline 07-15-93 & 2,300 & $<.2$ & 120,000 & 120,000 & 110,000 & 4,200 & 4,200 & 24,000 & 24,000 & 448 & 114 \\
\hline 04-19-94 & 2,100 & .4 & 150,000 & 150,000 & 150,000 & 3,400 & 3,300 & 30,000 & 29,000 & 640 & 178 \\
\hline $07-15-93$ & 2,400 & .3 & 61,000 & 54,000 & 2,400 & 4,000 & 4,000 & 28,000 & 27,000 & 580 & 386 \\
\hline $08-10-94$ & 1,600 & .5 & 15,000 & 8,000 & -- & 3,800 & 3,800 & 13,000 & 6,100 & 80 & -- \\
\hline $07-15-93$ & 1,300 & .3 & 26,000 & 25,000 & 980 & 3,100 & 3,000 & 22,000 & 22,000 & 380 & 216 \\
\hline 04-19-94 & 1,100 & .4 & 33,000 & 33,000 & 680 & 2,500 & 2,500 & 15,000 & 15,000 & 306 & 172 \\
\hline $07-15-93$ & 2,400 & .6 & 31,000 & 31,000 & 7,000 & 42,000 & 42,000 & 100,000 & 100,000 & 820 & 168 \\
\hline 04-19-94 & 1,400 & .6 & 5,900 & 5,500 & 1,500 & 23,000 & 23,000 & 65,000 & 65,000 & 512 & 68 \\
\hline $08-10-94$ & 690 & .2 & 1,300 & 1,200 & 180 & 700 & 690 & 6,400 & 6,200 & 100 & 15 \\
\hline $11-21-94$ & 1,100 & .2 & 1,800 & 1,500 & 170 & 810 & 740 & 7,300 & 6,600 & 70 & 17 \\
\hline $08-15-94$ & 1,600 & .6 & 18,000 & 17,000 & 5,400 & 4,100 & 4,100 & 3,400 & 3,400 & 140 & 58 \\
\hline $11-21-94$ & 3,200 & .6 & 26,000 & 23,000 & 5,700 & 5,000 & 4,600 & 3,900 & 3,600 & 140 & 84 \\
\hline $08-15-94$ & 3,000 & 1.3 & 180,000 & 97,000 & 180,000 & 8,500 & 8,400 & 8,900 & 8,700 & 478 & 314 \\
\hline $08-15-94$ & 2,900 & 1.4 & 190,000 & 190,000 & 160,000 & 9,500 & 9,400 & 12,000 & 12,000 & 526 & 100 \\
\hline $08-15-94$ & 470 & .2 & 1,400 & 980 & -- & 130 & 100 & $<130$ & $<130$ & 0 & -- \\
\hline $08-15-94$ & 960 & .3 & 28,000 & 26,000 & -- & 2,900 & 2,900 & $<130$ & $<130$ & 0 & -- \\
\hline $08-15-94$ & 120 & $<.2$ & 100 & $<10$ & -- & 10 & $<10$ & $<130$ & $<130$ & 0 & -- \\
\hline $08-15-94$ & 220 & $<.2$ & 30 & $<10$ & -- & $<10$ & $<10$ & $<130$ & $<130$ & 0 & -- \\
\hline $08-15-94$ & 250 & .2 & 1,900 & $<10$ & -- & 79 & 12 & 340 & $<130$ & 0 & -- \\
\hline $08-15-94$ & 370 & $<.2$ & 3,800 & 2,600 & 2,300 & 720 & 720 & 10,000 & 10,000 & 78 & -- \\
\hline $08-15-94$ & 160 & .3 & 230 & 22 & -- & 170 & 150 & 160 & $<130$ & 0 & -- \\
\hline $08-22-94$ & 140 & .3 & 240 & 50 & -- & 520 & 490 & 680 & 610 & 24 & -- \\
\hline $08-22-94$ & 110 & .3 & 350 & 130 & -- & 630 & 570 & 670 & 580 & 26 & -- \\
\hline 08-03-92 & 1,300 & $<.2$ & 150 & 150 & -- & 86 & 41 & 640 & 220 & 0 & -- \\
\hline $08-03-92$ & 2,100 & .7 & 7,000 & 6,400 & -- & 24,000 & 22,000 & 17,000 & 16,000 & 160 & 7 \\
\hline 08-04-92 & 1,400 & .3 & 48,000 & 48,000 & -- & 3,100 & 3,100 & 55,000 & 54,000 & 620 & 256 \\
\hline 05-09-94 & 320 & $<.2$ & 1,900 & 1,900 & 200 & 270 & 270 & 4,800 & 4,800 & 80 & 28 \\
\hline 08-04-92 & 610 & .3 & 52,000 & 51,000 & -- & 1,100 & 1,100 & 200 & $<100$ & 0 & 0 \\
\hline $10-11-94$ & 180 & $<.2$ & 420 & $<10$ & -- & 23 & $<10$ & 190 & $<130$ & 0 & -- \\
\hline 08-04-92 & 550 & .3 & 4,200 & 560 & -- & 950 & 940 & 6,200 & 4,000 & 42 & 0 \\
\hline 09-01-93 & 710 & .2 & 4,400 & 750 & 900 & 1,200 & 1,200 & 9,000 & 8,000 & 56 & -- \\
\hline 08-05-92 & 1,300 & .7 & 3,700 & 3,700 & -- & 13,000 & 13,000 & 120,000 & 120,000 & 680 & 30 \\
\hline 08-19-93 & 350 & .2 & 9,500 & 4,800 & -- & 1,300 & 1,300 & 3,500 & 370 & 0 & -- \\
\hline 05-04-94 & 330 & .3 & 6,100 & 2,100 & -- & 1,100 & 1,100 & 2,300 & 440 & 0 & -- \\
\hline $08-05-92$ & 300 & .3 & 8,700 & 3,700 & -- & 1,200 & 1,200 & 3,600 & 200 & 0 & 0 \\
\hline $08-05-92$ & 450 & $<.2$ & 8,100 & 7,500 & -- & 4,600 & 4,300 & 200 & 300 & 0 & 0 \\
\hline $08-06-92$ & 430 & .2 & 1,200 & 50 & -- & 1,600 & 1,600 & $<130$ & $<130$ & 0 & -- \\
\hline 07-07-93 & 1,300 & .6 & 2,400 & 2,000 & 990 & 53,000 & 51,000 & 33,000 & 32,000 & 252 & 24 \\
\hline 07-07-93 & 1,200 & .6 & 35,000 & 32,000 & 7,100 & 11,000 & 10,000 & 39,000 & 36,000 & 396 & 142 \\
\hline $07-07-93$ & 440 & .4 & 870 & 840 & 220 & 2,000 & 2,000 & 5,900 & 5,900 & 58 & 11 \\
\hline 07-07-93 & 610 & .4 & 4,000 & 2,600 & 540 & 6,600 & 6,500 & 4,700 & 4,300 & 108 & 62 \\
\hline $07-07-93$ & 490 & $<.2$ & 78,000 & 76,000 & -- & 4,100 & 4,100 & 290 & $<130$ & 120 & -- \\
\hline 07-08-93 & 990 & .3 & 44,000 & 43,000 & 3,000 & 3,100 & 3,000 & 19,000 & 18,000 & 356 & 214 \\
\hline
\end{tabular}




\begin{tabular}{|c|c|c|c|c|c|c|c|c|c|c|c|}
\hline $\begin{array}{c}\text { Site } \\
\text { number }\end{array}$ & $\begin{array}{c}\text { Local } \\
\text { identifier } \\
\text { (Topographic } \\
\text { quadrangle) }\end{array}$ & Date & Time & $\begin{array}{l}\text { Discharge, } \\
\text { instan- } \\
\text { taneous } \\
\left(\mathrm{ft}^{3} / \mathrm{s}\right)\end{array}$ & $\begin{array}{c}\text { Flow rate, } \\
\text { instan- } \\
\text { taneous } \\
\text { (gal/min) }\end{array}$ & $\begin{array}{l}\text { Temper- } \\
\text { ature, } \\
\text { water } \\
\left({ }^{\circ} \mathrm{C}\right)\end{array}$ & $\begin{array}{c}\text { Specific } \\
\text { conduc- } \\
\text { tance } \\
(\mu \mathrm{S} / \mathrm{cm})\end{array}$ & $\begin{array}{l}\mathrm{pH} \text {, water } \\
\text { whole } \\
\text { field } \\
\text { (standard } \\
\text { units) }\end{array}$ & $\begin{array}{l}\text { Alkalinity, } \\
\text { water } \\
(\mathrm{mg} / \mathrm{L} \text { as } \\
\left.\mathrm{CaCO}_{3}\right)\end{array}$ & $\begin{array}{c}\text { Residue at } \\
105^{\circ} \mathrm{C} \text {, } \\
\text { dissolved } \\
\text { (mg/L) }\end{array}$ & $\begin{array}{c}\text { Carbon, } \\
\text { inorganic, } \\
\text { total } \\
(\mathrm{mg} / \mathrm{L} \\
\text { as C) }\end{array}$ \\
\hline 218 & Windber & 07-08-93 & 1010 & 0.07 & 33 & 10.5 & 1,350 & 5.6 & 80 & 1,100 & 28 \\
\hline \multirow[t]{2}{*}{219} & Ogletown & 07-08-93 & 1130 & .04 & 18 & 27.0 & 3,270 & 2.4 & 0 & 3,530 & 1.0 \\
\hline & & 05-03-94 & 1530 & .15 & 68 & 11.0 & 1,500 & 2.6 & 0 & 1,310 & 1.0 \\
\hline 220 & Windber & 07-08-93 & 1300 & .02 & 8.6 & 10.0 & 782 & 3.5 & 0 & 514 & 1.4 \\
\hline 221 & Windber & 07-08-93 & 1440 & .13 & 60 & 16.5 & 1,280 & 3.2 & 0 & 1,190 & 1.1 \\
\hline 222 & Windber & 07-08-93 & 1523 & .00 & 1.2 & 13.0 & 572 & 5.6 & 24 & 662 & 8.7 \\
\hline 223 & Somerset & 08-16-94 & 1100 & .06 & 25 & 16.0 & 460 & 5.6 & 10 & 508 & 5.1 \\
\hline 224 & Windber & 08-16-93 & 1420 & .07 & 30 & 15.0 & 1,510 & 6.4 & 180 & 1,490 & 54 \\
\hline \multirow[t]{2}{*}{225} & Stoystown & 08-17-93 & 1525 & .02 & -- & 12.5 & 1,180 & 5.5 & 40 & -- & 7.9 \\
\hline & & 08-16-93 & 1620 & .13 & 60 & 12.5 & 995 & 6.3 & 26 & 946 & 13 \\
\hline 226 & Stoystown & 08-17-93 & 1525 & .02 & 7.5 & 12.5 & 1,180 & 5.5 & 40 & 364 & 7.9 \\
\hline \multirow[t]{2}{*}{227} & Stoystown & 08-18-93 & 1200 & .02 & 7.5 & 19.5 & 2,590 & 3.0 & 0 & 2,990 & $<1.0$ \\
\hline & & $04-21-94$ & 1015 & .19 & 85 & 9.0 & 1,890 & 2.8 & 0 & 1,760 & $<1.0$ \\
\hline 228 & Hooversville & 08-19-93 & 1115 & $<.01$ & $<.1$ & 10.0 & 1,760 & 5.5 & 24 & 1,990 & 25 \\
\hline 229 & Windber & $08-22-94$ & 1600 & .05 & 24 & 15.0 & 628 & 6.2 & 20 & 638 & 3.8 \\
\hline 230 & Windber & 08-22-94 & 1700 & .02 & 7.2 & 16.5 & 605 & 6.1 & 34 & 534 & 11 \\
\hline 231 & Windber & 09-06-94 & 1045 & .11 & 48 & 10.5 & 1,010 & 3.4 & 0 & 1,010 & 2.8 \\
\hline 232 & Windber & 09-06-94 & 1210 & $<.01$ & 1.3 & 20.0 & 2,270 & 2.7 & 0 & 2,060 & 3.0 \\
\hline 233 & Windber & 09-06-94 & 1250 & $<.01$ & 1.0 & 20.0 & 1,920 & 2.7 & 0 & 1,780 & $<1.0$ \\
\hline 234 & Windber & 09-06-94 & 1350 & .02 & 7.9 & 16.5 & 1,430 & 3.5 & 0 & 1,030 & 5.4 \\
\hline 235 & Windber & 09-06-94 & 1420 & .02 & 7.9 & 15.0 & 700 & 3.7 & 0 & 672 & 1.3 \\
\hline 236 & Windber & $09-12-94$ & 1015 & .10 & 45 & 9.5 & 1,120 & 5.4 & 15 & 1,130 & 18 \\
\hline \multirow[t]{2}{*}{237} & Windber & 09-06-94 & 1420 & .02 & 7.9 & 15.0 & 700 & 3.7 & 0 & 672 & 1.3 \\
\hline & & $09-12-94$ & 1115 & $<.01$ & .2 & 10.5 & 938 & 3.6 & 0 & 884 & 6.3 \\
\hline 238 & Windber & $09-12-94$ & 1215 & .03 & 14 & 10.0 & 1,060 & 5.3 & 40 & 1,080 & 24 \\
\hline 239 & Windber & $09-12-94$ & 1310 & $<.01$ & .1 & 11.0 & 266 & 6.0 & 44 & 196 & 20 \\
\hline 240 & Windber & 09-12-94 & 1515 & $<.01$ & .2 & 14.0 & 595 & 5.8 & 10 & 616 & 1.5 \\
\hline 241 & Hooversville & 09-13-94 & 0845 & .01 & 3.4 & 10.5 & 302 & 5.5 & 3 & 250 & 7.1 \\
\hline \multirow[t]{2}{*}{242} & Hooversville & 09-13-94 & 1000 & .05 & 22 & 18.5 & 11,600 & 2.3 & 0 & 27,340 & 2.2 \\
\hline & & $11-21-94$ & 1415 & .04 & 18 & 17.5 & 9,700 & 2.2 & 0 & 20,320 & 3.3 \\
\hline 243 & Hooversville & 09-19-94 & 1320 & .02 & 7.9 & 11.0 & 353 & 6.3 & 28 & 268 & 8.6 \\
\hline 244 & Hooversville & 09-19-94 & 1400 & .01 & 4.8 & 10.0 & 313 & 6.3 & 32 & 316 & 12 \\
\hline 245 & Hooversville & 09-19-94 & 1730 & .30 & 12 & 16.5 & 834 & 6.0 & 36 & 788 & 8.3 \\
\hline 246 & Windber & 09-19-94 & 1750 & .01 & 3.9 & 15.5 & 1,120 & 6.4 & 30 & 1,180 & 6.9 \\
\hline 247 & Windber & 09-19-94 & 1820 & .15 & 67 & 15.5 & 1,350 & 6.6 & 54 & 1,500 & 12 \\
\hline 248 & Johnstown & 09-20-94 & 0900 & .25 & 114 & 11.5 & 1,840 & 6.2 & 58 & 1,810 & 23 \\
\hline 249 & Hooversville & 09-21-94 & 1130 & .09 & 41 & 13.0 & 1,260 & 4.8 & 1 & 1,390 & 4.0 \\
\hline 250 & Hooversville & 09-21-94 & 1200 & $<.01$ & 1.4 & 14.0 & 1,420 & 3.1 & 0 & 1,420 & $<1.0$ \\
\hline 251 & Hooversville & 09-21-94 & 1230 & $<.01$ & .7 & 14.5 & 1,780 & 2.9 & 0 & 1,590 & $<1.0$ \\
\hline 252 & Hooversville & 09-21-94 & 1340 & $<.01$ & .8 & 13.5 & 1,650 & 3.3 & 0 & 2,110 & 3.6 \\
\hline 253 & Hooversville & 09-21-94 & 1500 & $<.01$ & 1.9 & 16.5 & 1,430 & 3.7 & 0 & 1,920 & $<1.0$ \\
\hline 254 & Hooversville & 09-21-94 & 1600 & $<.01$ & 1.0 & 16.5 & 820 & 3.4 & 0 & 690 & $<1.0$ \\
\hline 255 & Hooversville & $09-21-94$ & 1740 & .05 & 24 & 10.5 & 560 & 5.7 & 64 & 480 & 30 \\
\hline 256 & Somerset & 09-26-94 & 1030 & $<.01$ & .8 & 10.0 & 133 & 5.8 & 28 & 102 & 9.4 \\
\hline 257 & Somerset & 09-26-94 & 1200 & $<.01$ & 1.1 & 14.0 & 671 & 6.9 & 84 & 576 & 21 \\
\hline 258 & Somerset & 09-26-94 & 1300 & .01 & 3.3 & 14.5 & 1,310 & 3.8 & 0 & 1,380 & 5.0 \\
\hline 259 & Hooversville & 09-26-94 & 1450 & 1.9 & 867 & 11.5 & 878 & 6.3 & 98 & 748 & 24 \\
\hline 260 & Hooversville & $09-27-94$ & 0900 & .04 & 18 & 10.0 & 353 & 6.0 & 38 & 296 & 7.4 \\
\hline 261 & Stoystown & 10-03-94 & 1100 & .21 & 96 & 11.5 & 1,120 & 4.6 & 1 & 1,000 & 2.1 \\
\hline 262 & Stoystown & 10-03-94 & 1300 & .01 & 3.0 & 11.5 & 367 & 6.4 & 16 & 296 & 7.0 \\
\hline
\end{tabular}




\begin{tabular}{|c|c|c|c|c|c|c|c|c|c|c|c|}
\hline Date & $\begin{array}{c}\text { Sulfate, } \\
\text { dissolved } \\
(\mathrm{mg} / \mathrm{L} \\
\left.\text { as } \mathrm{SO}_{4}\right)\end{array}$ & $\begin{array}{l}\text { Fluoride, } \\
\text { total } \\
\text { (mg/L as F) }\end{array}$ & $\begin{array}{c}\text { Iron, total } \\
\text { recoverable } \\
(\mu \mathrm{g} / \mathrm{L} \\
\text { as Fe }\end{array}$ & $\begin{array}{c}\text { Iron, } \\
\text { dissolved } \\
(\mu \mathrm{g} / \mathrm{L} \\
\text { as Fe }\end{array}$ & $\begin{array}{c}\text { Iron, } \\
\text { ferrous, } \\
\text { dissolved } \\
(\mu \mathrm{g} / \mathrm{L} \\
\text { as Fe }\end{array}$ & $\begin{array}{c}\text { Manganese, } \\
\text { total } \\
\text { recoverable } \\
(\mu \mathrm{g} / \mathrm{L} \\
\text { as } \mathrm{Mn}\end{array}$ & $\begin{array}{c}\text { Manganese, } \\
\text { dissolved } \\
(\mu \mathrm{g} / \mathrm{L} \\
\text { as } \mathrm{Mn})\end{array}$ & $\begin{array}{l}\text { Aluminum, } \\
\text { total } \\
\text { recoverable } \\
(\mu \mathrm{g} / \mathrm{L} \\
\text { as Al) }\end{array}$ & $\begin{array}{c}\text { Aluminum, } \\
\text { dissolved } \\
(\mu \mathrm{g} / \mathrm{L} \\
\text { as Al) }\end{array}$ & $\begin{array}{c}\text { Acidity, } \\
\text { total } \\
\text { heated } \\
(\mathrm{mg} / \mathrm{L} \text { as } \\
\left.\mathrm{CaCO}_{3}\right)\end{array}$ & $\begin{array}{l}\text { Acidity, } \\
\text { mineral } \\
\text { (methyl } \\
\text { orange) } \\
(\mathrm{mg} / \mathrm{L} \text { as } \\
\left.\mathrm{CaCO}_{3}\right)\end{array}$ \\
\hline 07-08-93 & 670 & $<0.2$ & 690 & 220 & -- & 33 & 81 & 310 & 150 & 0 & -- \\
\hline $07-08-93$ & 2,400 & .8 & 160,000 & 140,000 & 10,000 & 31,000 & 30,000 & 13,000 & 12,000 & 940 & 608 \\
\hline 05-03-94 & 910 & .3 & 69,000 & 69,000 & -- & 13,000 & 13,000 & 5,600 & 5,600 & 328 & 208 \\
\hline 07-08-93 & 530 & .3 & 310 & 290 & 110 & 5,700 & 5,700 & 4,600 & 4,600 & 54 & 13 \\
\hline $07-08-93$ & 850 & .2 & 2,900 & 2,700 & 800 & 2,400 & 2,400 & 4,600 & 4,600 & 66 & 22 \\
\hline 07-08-93 & 290 & $<.2$ & 30 & 28 & -- & 45 & 45 & $<130$ & $<130$ & 0 & -- \\
\hline $08-16-94$ & 260 & $<.2$ & 2,500 & 2,500 & -- & 3,000 & 3,000 & 820 & 210 & 5.8 & -- \\
\hline $08-16-93$ & 750 & .3 & 830 & 450 & -- & 3,900 & 3,900 & 150 & 140 & 0 & -- \\
\hline $08-17-93$ & 170 & $<.2$ & 16,000 & 1,900 & -- & 5,300 & 2,300 & 540 & $<130$ & 0 & -- \\
\hline $08-16-93$ & 55 & .3 & 120,000 & 57,000 & -- & 6,600 & 6,600 & 8,500 & 910 & 76 & -- \\
\hline $08-17-93$ & 170 & $<.2$ & 16,000 & 1,900 & -- & 5,300 & 2,300 & 540 & $<130$ & 0 & -- \\
\hline $08-18-93$ & 1,600 & 1.1 & 21,000 & 21,000 & 1,500 & 19,000 & 19,000 & 110,000 & 110,000 & 940 & 258 \\
\hline $04-21-94$ & 1,100 & .7 & 12,000 & 12,000 & 1,300 & 14,000 & 13,000 & 71,000 & 69,000 & 536 & 142 \\
\hline $08-19-93$ & 1,300 & .2 & 220,000 & 170,000 & -- & 8,300 & 8,300 & 1,400 & 640 & 324 & -- \\
\hline $08-22-94$ & 340 & $<.2$ & 2,200 & 27 & -- & 380 & 95 & 270 & $<130$ & 0 & -- \\
\hline $08-22-94$ & 290 & .2 & 4,000 & 3,600 & -- & 2,000 & 2,000 & $<130$ & $<130$ & 0 & -- \\
\hline 09-06-94 & 830 & .4 & 1,600 & 880 & 320 & 10,000 & 10,000 & 5,700 & 5,700 & 108 & 18 \\
\hline 09-06-94 & 1,900 & $<.2$ & 69,000 & 68,000 & 39,000 & 23,000 & 23,000 & 1,300 & 1,300 & 422 & 250 \\
\hline 09-06-94 & 1,700 & $<.2$ & 41,000 & 41,000 & 2,500 & 23,000 & 23,000 & 4,000 & 4,000 & 336 & 206 \\
\hline 09-06-94 & 1,100 & .2 & 34,000 & 26,000 & 8,900 & 12,000 & 10,000 & 1,100 & 1,100 & 146 & 46 \\
\hline 09-06-94 & 640 & .3 & 620 & 500 & 130 & 7,500 & 7,300 & 2,000 & 1,900 & 60 & -- \\
\hline $09-12-94$ & 780 & $<.2$ & 40 & 24 & -- & 720 & 730 & 790 & 730 & 48 & -- \\
\hline $09-06-94$ & 640 & .3 & 620 & 500 & 130 & 7,500 & 7,300 & 2,000 & 1,900 & 60 & -- \\
\hline $09-12-94$ & 720 & .2 & 50,000 & 12,000 & 11,000 & 1,400 & 1,400 & 1,900 & 150 & 82 & 11 \\
\hline $09-12-94$ & 710 & $<.2$ & 70 & 69 & -- & 62 & 57 & 260 & 240 & 24 & -- \\
\hline $09-12-94$ & 88 & $<.2$ & 43,000 & 1,800 & -- & 1,300 & 1,400 & 1,000 & $<130$ & 20 & -- \\
\hline $09-12-94$ & 410 & $<.2$ & 4,700 & 29 & -- & 2,600 & 2,000 & 4,400 & $<130$ & 12 & -- \\
\hline 09-13-94 & 190 & .2 & 5,300 & 3,300 & -- & 1,600 & 1,600 & 250 & 250 & 22 & -- \\
\hline 09-13-94 & 20,000 & 8.9 & $2,750,000$ & $2,750,000$ & $2,440,000$ & 28,000 & 28,000 & 940,000 & 980,000 & 12,240 & 4,410 \\
\hline $11-21-94$ & 27,000 & -- & $2,660,000$ & $2,210,000$ & $2,120,000$ & 22,000 & 20,000 & 780,000 & 660,000 & 9,664 & 3,920 \\
\hline 09-19-94 & 130 & $<.2$ & 2,000 & 630 & -- & 43 & 35 & 330 & $<130$ & 0 & -- \\
\hline 09-19-94 & 110 & $<.2$ & 220 & 34 & -- & 17 & $<10$ & 190 & $<130$ & 0 & -- \\
\hline 09-19-94 & 470 & $<.2$ & 210 & 46 & -- & 120 & 90 & $<130$ & $<130$ & 0 & -- \\
\hline 09-19-94 & 690 & $<.2$ & 20 & -- & -- & 240 & -- & $<130$ & -- & 0 & -- \\
\hline $09-19-94$ & 840 & $<.2$ & 490 & 64 & -- & 840 & 800 & 150 & $<130$ & 0 & -- \\
\hline $09-20-94$ & 1,000 & .2 & 30,000 & 30,000 & -- & 1,400 & 1,400 & 3,900 & 650 & 13 & -- \\
\hline $09-21-94$ & 1,100 & .5 & 36,000 & 33,000 & -- & 5,600 & 5,500 & 1,600 & 1,500 & 84 & -- \\
\hline $09-21-94$ & 1,600 & 1 & 9,500 & 9,000 & 1,900 & 3,600 & 3,500 & 17,000 & 16,000 & 180 & 44 \\
\hline $09-21-94$ & 1,800 & 1.0 & 11,000 & 9,800 & 1,100 & 6,300 & 5,400 & 20,000 & 17,000 & 256 & 98 \\
\hline $09-21-94$ & 2,000 & 1.3 & 5,600 & 2,600 & 790 & 13,000 & 13,000 & 42,000 & 37,000 & 320 & 28 \\
\hline $09-21-94$ & 1,900 & .6 & 630 & 470 & 420 & 7,800 & 7,100 & 46,000 & 43,000 & 310 & 0 \\
\hline $09-21-94$ & 950 & .3 & 3,800 & 3,200 & 330 & 2,000 & 1,700 & 8,400 & 7,200 & 100 & 20 \\
\hline $09-21-94$ & 300 & $<.2$ & 7,100 & 6,500 & -- & 480 & 450 & 150 & $<130$ & 0 & -- \\
\hline $09-26-94$ & 31 & $<.2$ & 540 & 520 & -- & 240 & 240 & $<130$ & $<130$ & 5.4 & -- \\
\hline $09-26-94$ & 310 & .2 & 570 & 36 & -- & 33 & 16 & 460 & $<130$ & 0 & -- \\
\hline $09-26-94$ & 970 & .3 & 38,000 & 38,000 & 40,000 & 8,300 & 8,300 & 5,300 & 5,300 & 162 & 6 \\
\hline $09-26-94$ & 440 & .2 & 180 & 60 & -- & 190 & 180 & 320 & $<130$ & 0 & -- \\
\hline $09-27-94$ & 170 & $<.2$ & 9,400 & 8,500 & -- & 410 & 400 & $<130$ & $<130$ & 16 & -- \\
\hline $10-03-94$ & 830 & $<.2$ & 90 & 50 & -- & 7,100 & 6,600 & 3,300 & 3,100 & 28 & -- \\
\hline $10-03-94$ & 190 & $<0.2$ & 8,600 & 8,600 & -- & 2,500 & 2,100 & $<130$ & $<130$ & 4.0 & -- \\
\hline
\end{tabular}


Appendix 3. Field data and laboratory analyses of mine discharges_-Continued

\begin{tabular}{|c|c|c|c|c|c|c|c|c|c|c|c|}
\hline $\begin{array}{c}\text { Site } \\
\text { number }\end{array}$ & $\begin{array}{c}\text { Local } \\
\text { identifier } \\
\text { (Topographic } \\
\text { quadrangle) }\end{array}$ & Date & Time & $\begin{array}{l}\text { Discharge, } \\
\text { instan- } \\
\text { taneous } \\
\left(\mathrm{ft}^{3} / \mathrm{s}\right)\end{array}$ & $\begin{array}{c}\text { Flow rate, } \\
\text { instan- } \\
\text { taneous } \\
\text { (gal/min) }\end{array}$ & $\begin{array}{l}\text { Temper- } \\
\text { ature, } \\
\text { water } \\
\left({ }^{\circ} \mathrm{C}\right)\end{array}$ & $\begin{array}{c}\text { Specific } \\
\text { conduc- } \\
\text { tance } \\
(\mu \mathrm{S} / \mathrm{cm})\end{array}$ & $\begin{array}{l}\mathrm{pH} \text {, water } \\
\text { whole } \\
\text { field } \\
\text { (standard } \\
\text { units) }\end{array}$ & $\begin{array}{c}\text { Alkalinity, } \\
\text { water } \\
(\mathrm{mg} / \mathrm{L} \text { as } \\
\left.\mathrm{CaCO}_{3}\right)\end{array}$ & $\begin{array}{l}\text { Residue at } \\
105^{\circ} \mathrm{C} \\
\text { dissolved } \\
(\mathrm{mg} / \mathrm{L})\end{array}$ & $\begin{array}{c}\text { Carbon, } \\
\text { inorganic, } \\
\text { total } \\
(\mathrm{mg} / \mathrm{L} \\
\text { as C) }\end{array}$ \\
\hline 263 & Stoystown & $10-03-94$ & 1630 & 0.01 & 4.8 & 15.5 & 1,290 & 6.5 & 54 & 1,340 & 14 \\
\hline 264 & Stoystown & $10-03-94$ & 1710 & $<.01$ & 1.6 & 13.5 & 2,570 & 6.4 & 340 & 3,090 & 97 \\
\hline 265 & Central City & $10-11-94$ & 0930 & $<.01$ & 1.2 & 9.5 & 1,270 & 6.3 & 84 & -- & 9.2 \\
\hline 266 & Central City & $10-11-94$ & 1010 & $<.01$ & .8 & 8.0 & 2,160 & 6.8 & 168 & 1,650 & 44 \\
\hline 267 & Windber & $10-11-94$ & 1110 & $<.01$ & .4 & 10.5 & 210 & 6.6 & 90 & 148 & 26 \\
\hline 268 & Geistown & $10-11-94$ & 1330 & .09 & 40 & 11.5 & 1,200 & 6.3 & 64 & 1,230 & 19 \\
\hline 269 & Hooversville & $10-11-94$ & 1745 & .01 & 4.8 & 10.0 & 1,010 & 3.7 & 0 & 1,020 & $>2.7$ \\
\hline 270 & Hooversville & $10-11-94$ & 1840 & .18 & 80 & 9.5 & 713 & 6.6 & 112 & 682 & 28 \\
\hline
\end{tabular}


Appendix 3. Field data and laboratory analyses of mine discharges-Continued

\begin{tabular}{|c|c|c|c|c|c|c|c|c|c|c|c|}
\hline Date & $\begin{array}{l}\text { Sulfate, } \\
\text { dissolved } \\
(\mathrm{mg} / \mathrm{L} \\
\left.\text { as } \mathrm{SO}_{4}\right)\end{array}$ & $\begin{array}{l}\text { Fluoride, } \\
\quad \text { total } \\
\text { (mg/L as F) }\end{array}$ & $\begin{array}{l}\text { Iron, total } \\
\text { recoverable } \\
(\mu \mathrm{g} / \mathrm{L} \\
\text { as } \mathrm{Fe}\end{array}$ & $\begin{array}{c}\text { Iron, } \\
\text { dissolved } \\
(\mu \mathrm{g} / \mathrm{L} \\
\text { as Fe }\end{array}$ & $\begin{array}{c}\text { Iron, } \\
\text { ferrous, } \\
\text { dissolved } \\
(\mu \mathrm{g} / \mathrm{L} \\
\text { as Fe }\end{array}$ & $\begin{array}{c}\text { Manganese, } \\
\text { total } \\
\text { recoverable } \\
(\mu \mathrm{g} / \mathrm{L} \\
\text { as } \mathrm{Mn}\end{array}$ & $\begin{array}{c}\text { Manganese, } \\
\text { dissolved } \\
(\mu \mathrm{g} / \mathrm{L} \\
\text { as } \mathrm{Mn})\end{array}$ & $\begin{array}{l}\text { Aluminum, } \\
\text { total } \\
\text { recoverable } \\
(\mu \mathrm{g} / \mathrm{L} \\
\text { as Al) }\end{array}$ & $\begin{array}{c}\text { Aluminum, } \\
\text { dissolved } \\
(\mu \mathrm{g} / \mathrm{L} \\
\text { as Al) }\end{array}$ & $\begin{array}{c}\text { Acidity, } \\
\text { total } \\
\text { heated } \\
\left(\mathrm{mg}^{\prime} \mathrm{L} \text { as }\right. \\
\left.\mathrm{CaCO}_{3}\right)\end{array}$ & $\begin{array}{c}\text { Acidity, } \\
\text { mineral } \\
\text { (methyl } \\
\text { orange) } \\
(\mathrm{mg} / \mathrm{L} \text { as } \\
\left.\mathrm{CaCO}_{3}\right)\end{array}$ \\
\hline $10-03-94$ & 910 & $<0.2$ & 16,000 & 14,000 & -- & 1,700 & 1,500 & $<130$ & $<130$ & 0 & -- \\
\hline $10-03-94$ & 1,400 & $<.2$ & 2,900 & 2,400 & -- & 14,000 & 13,000 & $<130$ & $<130$ & 0 & -- \\
\hline $10-11-94$ & 480 & .3 & 72,000 & 63,000 & -- & 5,400 & 5,100 & 480 & $<130$ & 32 & -- \\
\hline $10-11-94$ & 480 & .2 & 6,500 & 4,200 & -- & 310 & 310 & $<130$ & $<130$ & 0 & -- \\
\hline $10-11-94$ & 4.5 & $<.2$ & 15,000 & 12,000 & -- & 3,000 & 3,000 & $<130$ & $<130$ & 0 & -- \\
\hline $10-11-94$ & 680 & $<.2$ & 700 & 280 & -- & 680 & 680 & 880 & 300 & 0 & -- \\
\hline $10-11-94$ & 980 & $<.2$ & 290 & 180 & 100 & 500 & 500 & 12,000 & 12,000 & 80 & 5 \\
\hline $10-11-94$ & 310 & .2 & 110 & 13 & -- & 10 & $<10$ & 200 & $<130$ & 0 & -- \\
\hline
\end{tabular}


Appendix 4. Prioritization index (PI) for all mine discharges

[lb/d, pounds per day; gal/min, gallons per minute; <, less than]

\begin{tabular}{|c|c|c|c|c|c|c|c|c|c|c|c|c|c|c|c|c|c|c|c|}
\hline $\begin{array}{c}\text { Site } \\
\text { number }\end{array}$ & $\begin{array}{c}\mathrm{pH} \\
\text { (units) }\end{array}$ & $\begin{array}{l}\text { Iron, } \\
\text { total } \\
(\mathrm{lb} / \mathrm{d} \\
\text { as Fe) }\end{array}$ & Rank & Score & $\begin{array}{c}\text { Acidity, } \\
\text { total } \\
\text { heated } \\
\text { (lb/d as } \\
\left.\mathrm{CaCO}_{3}\right)\end{array}$ & Rank & Score & $\begin{array}{c}\text { Sulfate, } \\
\text { total } \\
(\mathrm{lb} / \mathrm{d} \text { as } \\
\left.\mathrm{CaCO}_{3}\right)\end{array}$ & Rank & Score & $\begin{array}{c}\text { Aluminum, } \\
\text { dissolved } \\
\text { (lb/d } \\
\text { as Al) }\end{array}$ & Rank & Score & $\begin{array}{c}\text { Manganese, } \\
\text { total } \\
(\mathrm{lb} / \mathrm{d} \\
\text { as } \mathrm{Mn})\end{array}$ & Rank & Score & $\begin{array}{c}\text { Discharge, } \\
\text { instan- } \\
\text { taneous, } \\
\text { (gal/min) }\end{array}$ & $\begin{array}{l}\text { Final } \\
\text { score }\end{array}$ & $\mathrm{PI}$ \\
\hline 16 & 3.3 & 1,700 & 1 & 10 & 6,750 & 1 & 10 & 29,700 & 1 & 10 & 486 & 2 & 10 & 232 & 1 & 10 & 2,250 & 50 & 1 \\
\hline 19 & 5.1 & 876 & 3 & 10 & 1,580 & 6 & 10 & 10,300 & 4 & 10 & 25.6 & 20 & 10 & 85.4 & 4 & 10 & 1,780 & 50 & 2 \\
\hline 81 & 4.8 & 116 & 13 & 10 & 739 & 11 & 10 & 12,100 & 3 & 10 & 31.9 & 17 & 10 & 47.0 & 10 & 10 & 1,400 & 50 & 3 \\
\hline 95 & 4.6 & 41.2 & 24 & 10 & 353 & 23 & 10 & 8,120 & 6 & 10 & 34.1 & 15 & 10 & 23.5 & 19 & 10 & 981 & 50 & 4 \\
\hline 4 & 2.8 & 125 & 11 & 10 & 1,130 & 8 & 10 & 4,010 & 17 & 10 & 83.5 & 7 & 10 & 21.7 & 20 & 10 & 348 & 50 & 5 \\
\hline 125 & 2.4 & 351 & 6 & 10 & 3,180 & 3 & 10 & 8,640 & 5 & 10 & 232 & 4 & 10 & 178 & 2 & 10 & 225 & 50 & 6 \\
\hline 22 & 3.0 & 80.6 & 16 & 10 & 538 & 15 & 10 & 2,016 & 24 & 10 & 25.5 & 21 & 10 & 20.2 & 22 & 10 & 224 & 50 & 7 \\
\hline 3 & 2.8 & 140 & 10 & 10 & 1,170 & 7 & 10 & 2,976 & 19 & 10 & 100 & 5 & 10 & 42.8 & 11 & 10 & 155 & 50 & 8 \\
\hline 110 & 4.5 & 162 & 9 & 10 & 539 & 14 & 10 & 4,200 & 16 & 10 & 18.9 & 26 & 10 & 12.4 & 30 & 9 & 449 & 49 & 9 \\
\hline 208 & 6.2 & 16.6 & 39 & 9 & 3,050 & 4 & 10 & 5,830 & 10 & 10 & 539 & 1 & 10 & 58.3 & 9 & 10 & 374 & 49 & 10 \\
\hline 104 & 3.0 & 16.3 & 41 & 9 & 466 & 18 & 10 & 3,840 & 18 & 10 & 31.2 & 18 & 10 & 33.6 & 12 & 10 & 200 & 49 & 11 \\
\hline 141 & 2.7 & 121 & 12 & 10 & 751 & 10 & 10 & 864 & 49 & 9 & 42.6 & 10 & 10 & 63.4 & 7 & 10 & 48 & 49 & 12 \\
\hline 242 & 2.3 & 726 & 4 & 10 & 3,230 & 2 & 10 & 5,280 & 12 & 10 & 259 & 3 & 10 & 7.39 & 42 & 9 & 22 & 49 & 13 \\
\hline 14 & 3.6 & 8.44 & 62 & 8 & 844 & 9 & 10 & 7,000 & 8 & 10 & 93.0 & 6 & 10 & 64.2 & 6 & 10 & 799 & 48 & 14 \\
\hline 103 & 3.2 & 7.85 & 67 & 8 & 481 & 17 & 10 & 5,760 & 11 & 10 & 34.0 & 16 & 10 & 25.6 & 16 & 10 & 436 & 48 & 15 \\
\hline 63 & 3.4 & 13.6 & 45 & 9 & 465 & 19 & 10 & 864 & 48 & 9 & 63.2 & 8 & 10 & 25.9 & 14 & 10 & 277 & 48 & 16 \\
\hline 97 & 3.2 & 66.2 & 19 & 10 & 440 & 21 & 10 & 2,360 & 21 & 10 & 35.5 & 14 & 10 & 3.31 & 67 & 8 & 197 & 48 & 17 \\
\hline 160 & 3.1 & 12.1 & 49 & 9 & 246 & 27 & 10 & 1,970 & 25 & 10 & 14.6 & 31 & 9 & 26.7 & 13 & 10 & 171 & 48 & 18 \\
\hline 15 & 3.6 & 69.1 & 18 & 10 & 256 & 26 & 10 & 1,130 & 42 & 9 & 18.4 & 28 & 9 & 19.6 & 23 & 10 & 96 & 48 & 19 \\
\hline 38 & 3.0 & 61.8 & 21 & 10 & 414 & 22 & 10 & 796 & 51 & 9 & 38.4 & 13 & 10 & 6.08 & 47 & 9 & 78 & 48 & 20 \\
\hline 188 & 2.6 & 19.0 & 37 & 9 & 502 & 16 & 10 & 1,470 & 32 & 9 & 61.2 & 9 & 10 & 25.7 & 15 & 10 & 51 & 48 & 21 \\
\hline 121 & 6.0 & 13.8 & 44 & 9 & 138 & 41 & 9 & 7,250 & 7 & 10 & 5.98 & 52 & 9 & 17.0 & 26 & 10 & 1,510 & 47 & 22 \\
\hline 149 & 5.7 & 1116 & 2 & 10 & 2010 & 5 & 10 & 5,950 & 9 & 10 & 2.16 & 76 & 8 & 11.2 & 34 & 9 & 310 & 47 & 23 \\
\hline 6 & 4.4 & 36.4 & 28 & 9 & 125 & 45 & 9 & 2310 & 22 & 10 & 22.4 & 22 & 10 & 12.9 & 29 & 9 & 306 & 47 & 24 \\
\hline 164 & 2.8 & 30.3 & 32 & 9 & 303 & 25 & 10 & 978 & 45 & 9 & 18.6 & 27 & 10 & 5.94 & 48 & 9 & 97 & 47 & 25 \\
\hline 189 & 3.4 & 8.41 & 64 & 8 & 647 & 12 & 10 & 4460 & 15 & 10 & 40.1 & 11 & 10 & 4.53 & 61 & 8 & 539 & 46 & 26 \\
\hline 176 & 5.9 & 436 & 5 & 10 & 642 & 13 & 10 & 1780 & 27 & 10 & .40 & 126 & 6 & 24.2 & 18 & 10 & 330 & 46 & 27 \\
\hline 17 & 3.3 & 11.6 & 51 & 9 & 198 & 33 & 9 & 1260 & 36 & 9 & 17.0 & 29 & 9 & 6.48 & 45 & 9 & 284 & 45 & 28 \\
\hline 7 & 3.0 & 12.0 & 50 & 9 & 197 & 34 & 9 & 721 & 53 & 9 & 21.8 & 23 & 10 & 2.62 & 78 & 8 & 91 & 45 & 29 \\
\hline 204 & 2.7 & 34.6 & 30 & 9 & 446 & 20 & 10 & 1010 & 44 & 9 & 38.9 & 12 & 10 & 2.23 & 85 & 7 & 60 & 45 & 30 \\
\hline
\end{tabular}


Appendix 4. Prioritization index (PI) for all mine discharges-Continued

\begin{tabular}{|c|c|c|c|c|c|c|c|c|c|c|c|c|c|c|c|c|c|c|c|}
\hline $\begin{array}{c}\text { Site } \\
\text { number }\end{array}$ & $\begin{array}{c}\mathrm{pH} \\
\text { (units) }\end{array}$ & $\begin{array}{l}\text { Iron, } \\
\text { total } \\
(\mathrm{lb} / \mathrm{d} \\
\text { as Fe) }\end{array}$ & Rank & Score & $\begin{array}{c}\text { Acidity, } \\
\text { total } \\
\text { heated } \\
(\mathrm{lb} / \mathrm{d} \text { as } \\
\left.\mathrm{CaCO}_{3}\right)\end{array}$ & Rank & Score & $\begin{array}{c}\text { Sulfate, } \\
\text { total } \\
(\mathrm{lb} / \mathrm{d} \text { as } \\
\left.\mathrm{CaCO}_{3}\right)\end{array}$ & Rank & Score & $\begin{array}{c}\text { Aluminum, } \\
\text { dissolved } \\
\text { (lb/d } \\
\text { as } \mathrm{Al})\end{array}$ & Rank & Score & $\begin{array}{c}\text { Manganese, } \\
\text { total } \\
(\mathrm{lb} / \mathrm{d} \\
\text { as } \mathrm{Mn})\end{array}$ & Rank & Score & $\begin{array}{l}\text { Discharge, } \\
\text { instan- } \\
\text { taneous, } \\
\text { (gal/min) }\end{array}$ & $\begin{array}{l}\text { Final } \\
\text { score }\end{array}$ & $\mathrm{PI}$ \\
\hline 117 & 3.1 & 8.32 & 65 & 8 & 235 & 30 & 9 & 605 & 61 & 8 & 27.7 & 19 & 10 & 17.1 & 25 & 10 & 21 & 45 & 31 \\
\hline 165 & 2.7 & 69.1 & 17 & 10 & 346 & 24 & 10 & 475 & 72 & 8 & 21.0 & 24 & 10 & 1.23 & 99 & 7 & 18 & 45 & 32 \\
\hline 207 & 4.9 & 11.1 & 53 & 9 & 111 & 46 & 9 & 1460 & 33 & 9 & 10.6 & 35 & 9 & 2.52 & 81 & 8 & 221 & 44 & 33 \\
\hline 184 & 2.8 & 64.8 & 20 & 10 & 242 & 29 & 9 & 1240 & 39 & 9 & 13.0 & 32 & 9 & 2.27 & 84 & 7 & 45 & 44 & 34 \\
\hline 34 & 2.7 & 16.1 & 43 & 9 & 156 & 39 & 9 & 605 & 60 & 8 & 10.6 & 36 & 9 & 7.06 & 43 & 9 & 42 & 44 & 35 \\
\hline 140 & 2.5 & 22.7 & 35 & 9 & 222 & 31 & 9 & 648 & 57 & 8 & 10.4 & 37 & 9 & 15.6 & 28 & 9 & 27 & 44 & 36 \\
\hline 124 & 2.6 & 10.2 & 56 & 8 & 187 & 35 & 9 & 648 & 58 & 8 & 19.2 & 25 & 10 & 11.4 & 32 & 9 & 18 & 44 & 37 \\
\hline 190 & 3.1 & 13.0 & 48 & 9 & 101 & 47 & 9 & 1150 & 40 & 9 & 2.45 & 72 & 8 & 2.95 & 69 & 8 & 60 & 43 & 38 \\
\hline 219 & 2.4 & 34.6 & 29 & 9 & 203 & 32 & 9 & 518 & 70 & 8 & 2.59 & 71 & 8 & 6.70 & 44 & 9 & 18 & 43 & 39 \\
\hline 109 & 5.9 & 84.2 & 15 & 10 & 134 & 42 & 9 & 1400 & 34 & 9 & .37 & 131 & 6 & 4.54 & 60 & 8 & 180 & 42 & 40 \\
\hline 31 & 3.2 & 3.72 & 85 & 7 & 182 & 36 & 9 & 670 & 56 & 8 & 16.9 & 30 & 9 & 10.6 & 37 & 9 & 155 & 42 & 41 \\
\hline 101 & 3.2 & 2.39 & 92 & 7 & 132 & 43 & 9 & 1100 & 43 & 9 & 6.60 & 49 & 9 & 2.53 & 80 & 8 & 117 & 42 & 42 \\
\hline 40 & 3.1 & 4.32 & 79 & 8 & 148 & 40 & 9 & 378 & 81 & 8 & 12.6 & 34 & 9 & 4.86 & 55 & 8 & 75 & 42 & 43 \\
\hline 36 & 3.0 & 6.71 & 71 & 8 & 82.6 & 56 & 8 & 929 & 47 & 9 & 1.50 & 84 & 7 & 21.7 & 21 & 10 & 43 & 42 & 44 \\
\hline 187 & 2.4 & 11.2 & 52 & 9 & 164 & 38 & 9 & 562 & 65 & 8 & 9.50 & 41 & 9 & 1.34 & 96 & 7 & 36 & 42 & 45 \\
\hline 42 & 3.1 & 2.33 & 94 & 7 & 86.4 & 53 & 9 & 562 & 66 & 8 & 6.05 & 51 & 9 & 11.2 & 33 & 9 & 36 & 42 & 46 \\
\hline 180 & 2.7 & 54.0 & 22 & 10 & 246 & 28 & 9 & 420 & 77 & 8 & 12.9 & 33 & 9 & .60 & 129 & 6 & 25 & 42 & 47 \\
\hline 28 & 3.1 & 1.21 & 117 & 6 & 101 & 48 & 9 & 433 & 74 & 8 & 9.98 & 39 & 9 & 5.85 & 49 & 9 & 84 & 41 & 48 \\
\hline 172 & 2.8 & 2.38 & 93 & 7 & 93.6 & 51 & 9 & 342 & 84 & 7 & 8.64 & 43 & 9 & 5.04 & 54 & 9 & 30 & 41 & 49 \\
\hline 212 & 3.3 & .75 & 133 & 6 & 78.6 & 57 & 8 & 406 & 78 & 8 & 9.98 & 38 & 9 & 16.5 & 27 & 10 & 26 & 41 & 50 \\
\hline 1 & 2.8 & 8.83 & 60 & 8 & 73.0 & 59 & 8 & 288 & 93 & 7 & 6.14 & 50 & 9 & 5.76 & 50 & 9 & 16 & 41 & 51 \\
\hline 178 & 5.9 & 330 & 7 & 10 & .01 & 206 & 3 & 12400 & 2 & 10 & 3.89 & 59 & 8 & 12.1 & 31 & 9 & 1620 & 40 & 52 \\
\hline 130 & 3.9 & .24 & 164 & 4 & 90.0 & 52 & 9 & 1920 & 26 & 10 & 7.50 & 46 & 9 & 4.80 & 56 & 8 & 250 & 40 & 53 \\
\hline 10 & 3.5 & 1.10 & 119 & 6 & 35.1 & 77 & 8 & 571 & 64 & 8 & 2.78 & 70 & 8 & 133 & 3 & 10 & 122 & 40 & 54 \\
\hline 248 & 6.2 & 41.0 & 25 & 10 & 17.8 & 99 & 7 & 1370 & 35 & 9 & .89 & 99 & 7 & 1.92 & 88 & 7 & 114 & 40 & 55 \\
\hline 249 & 4.8 & 17.7 & 38 & 9 & 41.3 & 72 & 8 & 541 & 68 & 8 & .74 & 106 & 7 & 2.76 & 73 & 8 & 41 & 40 & 56 \\
\hline 126 & 2.9 & 1.22 & 116 & 6 & 86.1 & 54 & 9 & 253 & 97 & 7 & 8.74 & 42 & 9 & 7.49 & 41 & 9 & 26 & 40 & 57 \\
\hline 139 & 2.6 & 9.20 & 59 & 8 & 73.0 & 58 & 8 & 250 & 98 & 7 & 3.12 & 65 & 8 & 6.08 & 46 & 9 & 13 & 40 & 58 \\
\hline 60 & 2.9 & 1.38 & 112 & 6 & 55.3 & 63 & 8 & 384 & 80 & 8 & 6.60 & 48 & 9 & 10.8 & 35 & 9 & 6.4 & 40 & 59 \\
\hline 173 & 6.2 & 192 & 8 & 10 & .01 & 218 & 2 & 4570 & 14 & 10 & 1.13 & 93 & 7 & 24.8 & 17 & 10 & 470 & 39 & 60 \\
\hline
\end{tabular}


Appendix 4. Prioritization index (PI) for all mine discharges-Continued

\begin{tabular}{|c|c|c|c|c|c|c|c|c|c|c|c|c|c|c|c|c|c|c|c|}
\hline $\begin{array}{c}\text { Site } \\
\text { number }\end{array}$ & $\begin{array}{c}\mathrm{pH} \\
\text { (units) }\end{array}$ & $\begin{array}{l}\text { Iron, } \\
\text { total } \\
(\mathrm{lb} / \mathrm{d} \\
\text { as Fe) }\end{array}$ & Rank & Score & $\begin{array}{c}\text { Acidity, } \\
\text { total } \\
\text { heated } \\
(\mathrm{lb} / \mathrm{d} \text { as } \\
\left.\mathrm{CaCO}_{3}\right)\end{array}$ & Rank & Score & $\begin{array}{c}\text { Sulfate, } \\
\text { total } \\
(\mathrm{lb} / \mathrm{d} \text { as } \\
\left.\mathrm{CaCO}_{3}\right)\end{array}$ & Rank & Score & $\begin{array}{c}\text { Aluminum, } \\
\text { dissolved } \\
\text { (lb/d } \\
\text { as } \mathrm{Al})\end{array}$ & Rank & Score & $\begin{array}{c}\text { Manganese, } \\
\text { total } \\
(\mathrm{lb} / \mathrm{d} \\
\text { as } \mathrm{Mn})\end{array}$ & Rank & Score & $\begin{array}{l}\text { Discharge, } \\
\text { instan- } \\
\text { taneous, } \\
\text { (gal/min) }\end{array}$ & $\begin{array}{l}\text { Final } \\
\text { score }\end{array}$ & $\mathrm{PI}$ \\
\hline 11 & 4.4 & 9.47 & 57 & 8 & 32.6 & 80 & 8 & 588 & 63 & 8 & 1.31 & 89 & 7 & 2.61 & 79 & 8 & 136 & 39 & 61 \\
\hline 44 & 3.6 & .22 & 170 & 4 & 99.0 & 49 & 9 & 1150 & 41 & 9 & 8.62 & 44 & 9 & 3.99 & 63 & 8 & 133 & 39 & 62 \\
\hline 231 & 3.4 & .92 & 125 & 6 & 62.2 & 62 & 8 & 478 & 71 & 8 & 3.28 & 62 & 8 & 5.76 & 51 & 9 & 48 & 39 & 63 \\
\hline 5 & 4.5 & .16 & 180 & 4 & 38.5 & 75 & 8 & 1560 & 31 & 9 & 3.27 & 64 & 8 & 10.6 & 36 & 9 & 341 & 38 & 64 \\
\hline 221 & 3.2 & 2.09 & 96 & 7 & 47.5 & 68 & 8 & 612 & 59 & 8 & 3.31 & 61 & 8 & 1.73 & 92 & 7 & 60 & 38 & 65 \\
\hline 55 & 5.7 & 38.9 & 27 & 10 & 50.8 & 66 & 8 & 340 & 85 & 7 & .07 & 182 & 4 & 5.40 & 52 & 9 & 45 & 38 & 66 \\
\hline 156 & 3.5 & 1.90 & 100 & 7 & 43.2 & 71 & 8 & 605 & 62 & 8 & 5.18 & 56 & 8 & 1.21 & 101 & 7 & 36 & 38 & 67 \\
\hline 76 & 3.4 & 7.14 & 69 & 8 & 52.9 & 65 & 8 & 239 & 99 & 7 & 4.12 & 58 & 8 & 1.34 & 95 & 7 & 35 & 38 & 68 \\
\hline 166 & 2.7 & 23.4 & 34 & 9 & 128 & 44 & 9 & 234 & 100 & 7 & 7.02 & 47 & 9 & .30 & 164 & 4 & 13 & 38 & 69 \\
\hline 20 & 2.4 & 40.0 & 26 & 10 & 165 & 37 & 9 & 227 & 103 & 7 & 1.34 & 87 & 7 & .50 & 138 & 5 & .7 & 38 & 70 \\
\hline 144 & 6.0 & 28.9 & 33 & 9 & .01 & 208 & 3 & 2220 & 23 & 10 & .29 & 139 & 5 & 77.7 & 5 & 10 & 185 & 37 & 71 \\
\hline 261 & 4.6 & .10 & 195 & 3 & 32.3 & 81 & 8 & 956 & 46 & 9 & 3.57 & 60 & 8 & 8.18 & 39 & 9 & 96 & 37 & 72 \\
\hline 70 & 4.0 & .10 & 196 & 3 & 71.8 & 60 & 8 & 394 & 79 & 8 & 8.36 & 45 & 9 & 7.87 & 40 & 9 & 41 & 37 & 73 \\
\hline 227 & 3.0 & 1.89 & 101 & 7 & 84.6 & 55 & 8 & 144 & 118 & 6 & 9.90 & 40 & 9 & 1.71 & 93 & 7 & 7.5 & 37 & 74 \\
\hline 24 & 3.0 & 7.56 & 68 & 8 & 30.2 & 83 & 7 & 122 & 124 & 6 & 2.23 & 74 & 8 & 4.68 & 58 & 8 & 3 & 37 & 75 \\
\hline 142 & 2.2 & 4.20 & 81 & 8 & 33.6 & 79 & 8 & 102 & 132 & 6 & 1.47 & 85 & 7 & 2.79 & 72 & 8 & 2.5 & 37 & 76 \\
\hline 211 & 6.6 & 7.01 & 70 & 8 & .01 & 243 & 2 & 2510 & 20 & 10 & .76 & 102 & 7 & 9.35 & 38 & 9 & 487 & 36 & 77 \\
\hline 225 & 6.3 & 86.4 & 14 & 10 & 54.7 & 64 & 8 & 39.6 & 171 & 4 & .66 & 110 & 6 & 4.75 & 57 & 8 & 60 & 36 & 78 \\
\hline 21 & 3.3 & 3.81 & 84 & 7 & 34.2 & 78 & 8 & 348 & 83 & 7 & .66 & 109 & 6 & 3.92 & 64 & 8 & 46 & 36 & 79 \\
\hline 155 & 3.2 & .94 & 123 & 6 & 36.0 & 76 & 8 & 336 & 86 & 7 & 3.12 & 66 & 8 & 1.20 & 102 & 7 & 20 & 36 & 80 \\
\hline 46 & 3.2 & 1.80 & 103 & 7 & 50.4 & 67 & 8 & 118 & 126 & 6 & 5.28 & 55 & 8 & 1.18 & 104 & 7 & 20 & 36 & 81 \\
\hline 8 & 2.8 & 4.32 & 80 & 8 & 39.0 & 74 & 8 & 104 & 130 & 6 & 4.32 & 57 & 8 & .57 & 134 & 6 & 5.8 & 36 & 82 \\
\hline 59 & 2.9 & 2.72 & 90 & 7 & 24.6 & 88 & 7 & 100 & 133 & 6 & 2.05 & 78 & 8 & 2.90 & 71 & 8 & 3.1 & 36 & 83 \\
\hline 79 & 2.2 & 31.2 & 31 & 9 & 94.6 & 50 & 9 & 149 & 116 & 6 & 2.38 & 73 & 8 & .24 & 172 & 4 & 2 & 36 & 84 \\
\hline 170 & 6.2 & 16.5 & 40 & 9 & .01 & 220 & 2 & 1700 & 30 & 9 & .34 & 136 & 5 & 59.6 & 8 & 10 & 142 & 35 & 85 \\
\hline 12 & 6.4 & 13.4 & 46 & 9 & .01 & 228 & 2 & 1750 & 29 & 9 & .21 & 148 & 5 & 17.5 & 24 & 10 & 86 & 35 & 86 \\
\hline 62 & 3.5 & .23 & 169 & 4 & 39.9 & 73 & 8 & 162 & 113 & 6 & 5.62 & 54 & 9 & 3.06 & 68 & 8 & 52 & 35 & 87 \\
\hline 58 & 5.9 & 19.7 & 36 & 9 & 19.3 & 97 & 7 & 332 & 88 & 7 & .21 & 145 & 5 & 1.85 & 89 & 7 & 35 & 35 & 88 \\
\hline 186 & 4.8 & 3.96 & 82 & 7 & 21.1 & 95 & 7 & 422 & 75 & 8 & 1.61 & 82 & 7 & 1.00 & 109 & 6 & 22 & 35 & 89 \\
\hline 100 & 5.8 & .21 & 173 & 4 & 5.07 & 137 & 5 & 1770 & 28 & 9 & 1.86 & 79 & 8 & 2.91 & 70 & 8 & 352 & 34 & 90 \\
\hline
\end{tabular}


Appendix 4. Prioritization index (PI) for all mine discharges-Continued

\begin{tabular}{|c|c|c|c|c|c|c|c|c|c|c|c|c|c|c|c|c|c|c|c|}
\hline $\begin{array}{c}\text { Site } \\
\text { number }\end{array}$ & $\begin{array}{c}\mathrm{pH} \\
\text { (units) }\end{array}$ & $\begin{array}{l}\text { Iron, } \\
\text { total } \\
(\mathrm{lb} / \mathrm{d} \\
\text { as } \mathrm{Fe})\end{array}$ & Rank & Score & $\begin{array}{c}\text { Acidity, } \\
\text { total } \\
\text { heated } \\
(\mathrm{lb} / \mathrm{d} \text { as } \\
\left.\mathrm{CaCO}_{3}\right)\end{array}$ & Rank & Score & $\begin{array}{c}\text { Sulfate, } \\
\text { total } \\
(\mathrm{lb} / \mathrm{d} \text { as } \\
\left.\mathrm{CaCO}_{3}\right)\end{array}$ & Rank & Score & $\begin{array}{c}\text { Aluminum, } \\
\text { dissolved } \\
\text { (lb/d } \\
\text { as } \mathrm{Al} \text { ) }\end{array}$ & Rank & Score & $\begin{array}{c}\text { Manganese, } \\
\text { total } \\
(\mathrm{lb} / \mathrm{d} \\
\text { as } \mathrm{Mn})\end{array}$ & Rank & Score & $\begin{array}{l}\text { Discharge, } \\
\text { instan- } \\
\text { taneous, } \\
\text { (gal/min) }\end{array}$ & $\begin{array}{l}\text { Final } \\
\text { score }\end{array}$ & PI \\
\hline 210 & 5.8 & 9.43 & 58 & 8 & $<0.01$ & 205 & 3 & 524 & 69 & 8 & 0.35 & 134 & 6 & 5.35 & 53 & 9 & 97 & 34 & 91 \\
\hline 75 & 3.3 & 1.98 & 99 & 7 & 28.8 & 85 & 7 & 176 & 111 & 6 & 1.22 & 90 & 7 & 1.22 & 100 & 7 & 30 & 34 & 92 \\
\hline 161 & 3.2 & .86 & 129 & 6 & 19.7 & 96 & 7 & 185 & 106 & 7 & .62 & 112 & 6 & 2.64 & 77 & 8 & 20 & 34 & 93 \\
\hline 129 & 3.7 & .17 & 179 & 4 & 18.8 & 98 & 7 & 306 & 91 & 7 & 1.75 & 80 & 8 & 3.67 & 66 & 8 & 17 & 34 & 94 \\
\hline 72 & 3.7 & .08 & 205 & 3 & 45.4 & 69 & 8 & 144 & 117 & 6 & 5.78 & 53 & 9 & 4.54 & 59 & 8 & 8.6 & 34 & 95 \\
\hline 191 & 2.8 & 10.8 & 54 & 9 & 28.7 & 86 & 7 & 180 & 107 & 7 & .52 & 118 & 6 & .51 & 137 & 5 & 5 & 34 & 96 \\
\hline 259 & 6.3 & 1.87 & 102 & 7 & .01 & 227 & 2 & 4580 & 13 & 10 & 1.35 & 86 & 7 & 1.98 & 87 & 7 & 867 & 33 & 97 \\
\hline 111 & 3.4 & .19 & 175 & 4 & 29.5 & 84 & 7 & 216 & 104 & 7 & 3.06 & 69 & 8 & 2.34 & 82 & 7 & 30 & 33 & 98 \\
\hline 154 & 3.5 & .74 & 134 & 6 & 16.8 & 100 & 7 & 232 & 101 & 7 & .24 & 143 & 5 & 2.69 & 76 & 8 & 28 & 33 & 99 \\
\hline 128 & 3.6 & .08 & 206 & 3 & 22.2 & 91 & 7 & 336 & 87 & 7 & 2.15 & 77 & 8 & 3.70 & 65 & 8 & 28 & 33 & 100 \\
\hline 177 & 2.7 & 4.96 & 75 & 8 & 43.7 & 70 & 8 & 84.0 & 141 & 5 & 3.28 & 63 & 8 & .14 & 184 & 4 & 7 & 33 & 101 \\
\hline 94 & 3.0 & 3.90 & 83 & 7 & 21.4 & 94 & 7 & 51.0 & 167 & 4 & .75 & 103 & 7 & 4.50 & 62 & 8 & 2.5 & 33 & 102 \\
\hline 73 & 3.5 & 1.73 & 104 & 7 & 15.0 & 102 & 7 & 76.8 & 147 & 5 & 1.09 & 94 & 7 & 2.30 & 83 & 7 & 1.6 & 33 & 103 \\
\hline 137 & 5.3 & .11 & 192 & 3 & 64.8 & 61 & 8 & 367 & 82 & 7 & 2.16 & 75 & 8 & .67 & 126 & 6 & 180 & 32 & 104 \\
\hline 13 & 6.0 & 5.18 & 74 & 8 & .01 & 210 & 3 & 749 & 52 & 9 & .25 & 142 & 5 & 1.81 & 91 & 7 & 52 & 32 & 105 \\
\hline 169 & 6.0 & 13.3 & 47 & 9 & 21.6 & 93 & 7 & 130 & 121 & 6 & .05 & 192 & 3 & 2.16 & 86 & 7 & 15 & 32 & 106 \\
\hline 174 & 5.0 & 16.2 & 42 & 9 & 30.6 & 82 & 7 & 83.7 & 143 & 5 & .07 & 181 & 4 & 1.17 & 105 & 7 & 7.5 & 32 & 107 \\
\hline 71 & 3.8 & .10 & 198 & 3 & 24.3 & 90 & 7 & 100 & 135 & 6 & 3.10 & 68 & 8 & 2.69 & 74 & 8 & 3.8 & 32 & 108 \\
\hline 77 & 3.8 & .10 & 199 & 3 & 24.3 & 89 & 7 & 100 & 134 & 6 & 3.10 & 67 & 8 & 2.69 & 75 & 8 & 3.8 & 32 & 109 \\
\hline 32 & 3.4 & .24 & 167 & 4 & 13.8 & 105 & 7 & 207 & 105 & 7 & 1.32 & 88 & 7 & .93 & 113 & 6 & 18 & 31 & 110 \\
\hline 116 & 3.6 & .16 & 184 & 4 & 13.7 & 106 & 7 & 178 & 110 & 6 & 1.15 & 92 & 7 & 1.19 & 103 & 7 & 15 & 31 & 111 \\
\hline 234 & 3.5 & 3.22 & 86 & 7 & 13.8 & 104 & 7 & 104 & 131 & 6 & .10 & 169 & 4 & 1.14 & 106 & 7 & 7.9 & 31 & 112 \\
\hline 205 & 6.3 & 46.8 & 23 & 10 & .01 & 221 & 2 & 549 & 67 & 8 & .09 & 176 & 4 & .99 & 110 & 6 & 75 & 30 & 113 \\
\hline 78 & 4.5 & .02 & 235 & 2 & 21.8 & 92 & 7 & 679 & 54 & 9 & .63 & 111 & 6 & .94 & 112 & 6 & 65 & 30 & 114 \\
\hline 179 & 3.8 & 8.55 & 61 & 8 & 15.5 & 101 & 7 & 72.0 & 150 & 5 & .06 & 185 & 4 & .54 & 135 & 6 & 7.5 & 30 & 115 \\
\hline 209 & 3.5 & 6.68 & 72 & 8 & .01 & 199 & 3 & 230 & 102 & 7 & .15 & 156 & 5 & .92 & 114 & 6 & 64 & 29 & 116 \\
\hline 2 & 3.1 & .41 & 148 & 5 & 9.94 & 115 & 6 & 107 & 128 & 6 & .56 & 116 & 6 & .95 & 111 & 6 & 9 & 29 & 117 \\
\hline 181 & 3.3 & 1.68 & 106 & 7 & 8.76 & 119 & 6 & 54.0 & 161 & 5 & .19 & 149 & 5 & .78 & 119 & 6 & 5 & 29 & 118 \\
\hline 162 & 3.1 & .15 & 185 & 4 & 7.80 & 124 & 6 & 84.0 & 142 & 5 & .72 & 107 & 7 & 1.02 & 107 & 7 & 5 & 29 & 119 \\
\hline 192 & 3.3 & 4.79 & 76 & 8 & 13.3 & 107 & 7 & 73.1 & 149 & 5 & .30 & 138 & 5 & .24 & 173 & 4 & 2.1 & 29 & 120 \\
\hline
\end{tabular}


Appendix 4. Prioritization index (PI) for all mine discharges-Continued

\begin{tabular}{|c|c|c|c|c|c|c|c|c|c|c|c|c|c|c|c|c|c|c|c|}
\hline $\begin{array}{c}\text { Site } \\
\text { number }\end{array}$ & $\begin{array}{c}\mathrm{pH} \\
\text { (units) }\end{array}$ & $\begin{array}{l}\text { Iron, } \\
\text { total } \\
(\mathrm{lb} / \mathrm{d} \\
\text { as Fe) }\end{array}$ & Rank & Score & $\begin{array}{c}\text { Acidity, } \\
\text { total } \\
\text { heated } \\
(\mathrm{lb} / \mathrm{d} \text { as } \\
\left.\mathrm{CaCO}_{3}\right)\end{array}$ & Rank & Score & $\begin{array}{c}\text { Sulfate, } \\
\text { total } \\
(\mathrm{lb} / \mathrm{d} \text { as } \\
\mathrm{CaCO}_{3} \text { ) }\end{array}$ & Rank & Score & $\begin{array}{c}\text { Aluminum, } \\
\text { dissolved } \\
\text { (lb/d } \\
\text { as Al) }\end{array}$ & Rank & Score & $\begin{array}{c}\text { Manganese, } \\
\text { total } \\
(\mathrm{lb} / \mathrm{d} \\
\text { as } \mathrm{Mn})\end{array}$ & Rank & Score & $\begin{array}{l}\text { Discharge, } \\
\text { instan- } \\
\text { taneous, } \\
\text { (gal/min) }\end{array}$ & $\begin{array}{l}\text { Final } \\
\text { score }\end{array}$ & PI \\
\hline 26 & 3.1 & 0.41 & 147 & 5 & 8.82 & 118 & 6 & 39.6 & 170 & 4 & 0.99 & 96 & 7 & 1.01 & 108 & 7 & 1.5 & 29 & 121 \\
\hline 236 & 5.4 & .02 & 238 & 2 & 25.9 & 87 & 7 & 421 & 76 & 8 & .39 & 127 & 6 & .39 & 153 & 5 & 45 & 28 & 122 \\
\hline 56 & 4.2 & .06 & 216 & 3 & 7.68 & 125 & 6 & 55.2 & 158 & 5 & .84 & 101 & 7 & 1.27 & 98 & 7 & 20 & 28 & 123 \\
\hline 82 & 6.1 & 8.21 & 66 & 8 & 8.06 & 123 & 6 & 69.1 & 151 & 5 & .02 & 211 & 3 & .68 & 124 & 6 & 12 & 28 & 124 \\
\hline 175 & 3.2 & 2.22 & 95 & 7 & 7.20 & 128 & 6 & 28.8 & 187 & 4 & .32 & 137 & 5 & .66 & 128 & 6 & 5 & 28 & 125 \\
\hline 151 & 6.5 & 4.54 & 77 & 8 & .01 & 238 & 2 & 287 & 94 & 7 & .15 & 157 & 5 & .39 & 152 & 5 & 126 & 27 & 126 \\
\hline 35 & 6.0 & 3.00 & 89 & 7 & .01 & 207 & 3 & 173 & 112 & 6 & .12 & 164 & 4 & 1.84 & 90 & 7 & 48 & 27 & 127 \\
\hline 23 & 3.4 & .04 & 226 & 2 & 14.4 & 103 & 7 & 51.8 & 166 & 4 & 1.58 & 83 & 7 & 1.30 & 97 & 7 & 12 & 27 & 128 \\
\hline 112 & 3.5 & .06 & 219 & 2 & 10.7 & 113 & 6 & 132 & 120 & 6 & 1.15 & 91 & 7 & .75 & 120 & 6 & 12 & 27 & 129 \\
\hline 215 & 3.0 & .35 & 152 & 5 & 9.46 & 117 & 6 & 53.4 & 163 & 4 & .38 & 129 & 6 & .58 & 132 & 6 & 7.3 & 27 & 130 \\
\hline 258 & 3.8 & 1.51 & 108 & 7 & 6.42 & 131 & 6 & 38.4 & 174 & 4 & .21 & 147 & 5 & .33 & 160 & 5 & 3.3 & 27 & 131 \\
\hline 213 & 3.0 & .97 & 122 & 6 & 10.9 & 111 & 6 & 33.1 & 178 & 4 & .99 & 95 & 7 & .30 & 163 & 4 & 2.3 & 27 & 132 \\
\hline 185 & 2.7 & 1.39 & 111 & 6 & 13.2 & 108 & 7 & 54.7 & 159 & 5 & .62 & 114 & 6 & .09 & 198 & 3 & 1.9 & 27 & 133 \\
\hline 152 & 6.5 & .14 & 186 & 4 & .01 & 236 & 2 & 1250 & 38 & 9 & .35 & 135 & 6 & .35 & 158 & 5 & 289 & 26 & 134 \\
\hline 123 & 6.4 & .51 & 143 & 5 & .01 & 231 & 2 & 1250 & 37 & 9 & .39 & 128 & 6 & .15 & 182 & 4 & 248 & 26 & 135 \\
\hline 54 & 6.7 & 10.5 & 55 & 8 & .01 & 251 & 1 & 129 & 122 & 6 & .19 & 151 & 5 & .84 & 118 & 6 & 111 & 26 & 136 \\
\hline 29 & 4.1 & .01 & 254 & 1 & 11.9 & 110 & 6 & 141 & 119 & 6 & 1.62 & 81 & 8 & .32 & 162 & 5 & 19 & 26 & 137 \\
\hline 214 & 3.1 & .13 & 188 & 4 & 8.35 & 122 & 6 & 63.4 & 154 & 5 & .85 & 100 & 7 & .29 & 165 & 4 & 12 & 26 & 138 \\
\hline 41 & 5.5 & 8.42 & 63 & 8 & 13.0 & 109 & 6 & 52.9 & 164 & 4 & .01 & 213 & 3 & .44 & 146 & 5 & 9 & 26 & 139 \\
\hline 48 & 4.5 & .61 & 141 & 5 & 4.80 & 139 & 5 & 53.8 & 162 & 5 & .27 & 141 & 5 & .87 & 116 & 6 & 8 & 26 & 140 \\
\hline 113 & 3.3 & .04 & 227 & 2 & 8.72 & 120 & 6 & 94.8 & 138 & 5 & .91 & 98 & 7 & .58 & 131 & 6 & 7.9 & 26 & 141 \\
\hline 158 & 3.8 & 1.20 & 118 & 6 & 5.10 & 136 & 5 & 21.6 & 196 & 3 & .44 & 123 & 6 & .72 & 122 & 6 & .5 & 26 & 142 \\
\hline 122 & 2.9 & 1.66 & 107 & 7 & 8.69 & 121 & 6 & 14.6 & 215 & 3 & .74 & 104 & 7 & .09 & 200 & 3 & .2 & 26 & 143 \\
\hline 223 & 5.6 & .75 & 132 & 6 & 1.74 & 169 & 4 & 78.0 & 146 & 5 & .06 & 186 & 4 & .90 & 115 & 6 & 25 & 25 & 144 \\
\hline 220 & 3.5 & .03 & 232 & 2 & 5.57 & 134 & 6 & 54.7 & 160 & 5 & .47 & 121 & 6 & .59 & 130 & 6 & 8.6 & 25 & 145 \\
\hline 235 & 3.7 & .06 & 215 & 3 & 5.69 & 133 & 6 & 60.7 & 155 & 5 & .18 & 152 & 5 & .71 & 123 & 6 & 7.9 & 25 & 146 \\
\hline 216 & 5.5 & 6.27 & 73 & 8 & 9.65 & 116 & 6 & 39.4 & 172 & 4 & .01 & 225 & 2 & .33 & 159 & 5 & 6.7 & 25 & 147 \\
\hline 217 & 2.9 & 1.32 & 114 & 6 & 10.7 & 112 & 6 & 29.7 & 184 & 4 & .54 & 117 & 6 & .09 & 196 & 3 & 2.5 & 25 & 148 \\
\hline 247 & 6.6 & .39 & 149 & 5 & .01 & 244 & 1 & 675 & 55 & 8 & .10 & 168 & 4 & .68 & 125 & 6 & 67 & 24 & 149 \\
\hline 268 & 6.3 & .34 & 156 & 5 & .01 & 226 & 2 & 326 & 89 & 7 & .14 & 158 & 5 & .33 & 161 & 5 & 40 & 24 & 150 \\
\hline
\end{tabular}


Appendix 4. Prioritization index (PI) for all mine discharges-Continued

\begin{tabular}{|c|c|c|c|c|c|c|c|c|c|c|c|c|c|c|c|c|c|c|c|}
\hline $\begin{array}{c}\text { Site } \\
\text { number }\end{array}$ & $\begin{array}{c}\mathrm{pH} \\
\text { (units) }\end{array}$ & $\begin{array}{l}\text { Iron, } \\
\text { total } \\
(\mathrm{lb} / \mathrm{d} \\
\text { as } \mathrm{Fe})\end{array}$ & Rank & Score & $\begin{array}{c}\text { Acidity, } \\
\text { total } \\
\text { heated } \\
(\mathrm{lb} / \mathrm{d} \text { as } \\
\left.\mathrm{CaCO}_{3}\right)\end{array}$ & Rank & Score & $\begin{array}{c}\text { Sulfate, } \\
\text { total } \\
(\mathrm{lb} / \mathrm{d} \text { as } \\
\left.\mathrm{CaCO}_{3}\right)\end{array}$ & Rank & Score & $\begin{array}{c}\text { Aluminum, } \\
\text { dissolved } \\
\text { (lb/d } \\
\text { as } \mathrm{Al} \text { ) }\end{array}$ & Rank & Score & $\begin{array}{c}\text { Manganese, } \\
\text { total } \\
(\mathrm{lb} / \mathrm{d} \\
\text { as } \mathrm{Mn})\end{array}$ & Rank & Score & $\begin{array}{l}\text { Discharge, } \\
\text { instan- } \\
\text { taneous, } \\
\text { (gal/min) }\end{array}$ & $\begin{array}{l}\text { Final } \\
\text { score }\end{array}$ & PI \\
\hline 224 & 6.4 & 0.30 & 160 & 5 & $<0.01$ & 229 & 2 & 270 & 95 & 7 & 0.05 & 194 & 3 & 1.40 & 94 & 7 & 30 & 24 & 151 \\
\hline 33 & 3.9 & .03 & 231 & 2 & 4.44 & 143 & 5 & 86.7 & 139 & 5 & .50 & 120 & 6 & .57 & 133 & 6 & 8.4 & 24 & 152 \\
\hline 114 & 3.5 & .04 & 228 & 2 & 5.94 & 132 & 6 & 79.2 & 145 & 5 & .58 & 115 & 6 & .48 & 142 & 5 & 5.5 & 24 & 153 \\
\hline 30 & 3.1 & .11 & 191 & 3 & 7.39 & 127 & 6 & 24.8 & 193 & 3 & .74 & 105 & 7 & .40 & 150 & 5 & 4.4 & 24 & 154 \\
\hline 232 & 2.7 & 1.08 & 120 & 6 & 6.58 & 130 & 6 & 29.6 & 185 & 4 & .02 & 206 & 3 & .36 & 157 & 5 & 1.3 & 24 & 155 \\
\hline 127 & 2.6 & 1.72 & 105 & 7 & 7.58 & 126 & 6 & 25.0 & 192 & 3 & .02 & 209 & 3 & .50 & 140 & 5 & 1.3 & 24 & 156 \\
\hline 39 & 6.2 & .62 & 140 & 5 & .01 & 216 & 3 & 159 & 114 & 6 & .08 & 180 & 4 & .46 & 143 & 5 & 63 & 23 & 157 \\
\hline 96 & 6.3 & .38 & 150 & 5 & .01 & 223 & 2 & 437 & 73 & 8 & .08 & 178 & 4 & .29 & 167 & 4 & 52 & 23 & 158 \\
\hline 194 & 6.8 & 4.37 & 78 & 8 & .01 & 255 & 1 & 150 & 115 & 6 & .02 & 207 & 3 & .45 & 145 & 5 & 13 & 23 & 159 \\
\hline 120 & 3.2 & .51 & 142 & 5 & 10.1 & 114 & 6 & 31.5 & 182 & 4 & .07 & 183 & 4 & .19 & 176 & 4 & 7.5 & 23 & 160 \\
\hline 115 & 3.6 & .05 & 224 & 2 & 4.31 & 145 & 5 & 56.2 & 157 & 5 & .37 & 130 & 6 & .51 & 136 & 5 & 3.9 & 23 & 161 \\
\hline 159 & 4.6 & .09 & 204 & 3 & 2.54 & 162 & 5 & 21.3 & 197 & 3 & .36 & 132 & 6 & .66 & 127 & 6 & 2.3 & 23 & 162 \\
\hline 163 & 3.0 & .17 & 178 & 4 & 3.36 & 155 & 5 & 28.8 & 186 & 4 & .17 & 154 & 5 & .50 & 139 & 5 & 2 & 23 & 163 \\
\hline 253 & 3.7 & .01 & 242 & 2 & 7.07 & 129 & 6 & 43.3 & 168 & 4 & .98 & 97 & 7 & .18 & 180 & 4 & 1.9 & 23 & 164 \\
\hline 138 & 2.7 & .33 & 157 & 5 & 4.11 & 146 & 5 & 16.7 & 206 & 3 & .21 & 146 & 5 & .44 & 147 & 5 & 1.6 & 23 & 165 \\
\hline 47 & 3.2 & .73 & 135 & 6 & 3.69 & 151 & 5 & 14.8 & 214 & 3 & .17 & 153 & 5 & .27 & 169 & 4 & 1.6 & 23 & 166 \\
\hline 171 & 6.6 & .79 & 131 & 6 & .01 & 247 & 1 & 124 & 123 & 6 & .11 & 166 & 4 & .42 & 149 & 5 & 69 & 22 & 167 \\
\hline 135 & 6.6 & .86 & 130 & 6 & .01 & 242 & 2 & 180 & 108 & 7 & .09 & 170 & 4 & .10 & 192 & 3 & 60 & 22 & 168 \\
\hline 202 & 6.1 & .10 & 200 & 3 & .01 & 212 & 3 & 842 & 50 & 9 & .14 & 160 & 5 & .06 & 218 & 2 & 54 & 22 & 169 \\
\hline 255 & 5.7 & 2.05 & 97 & 7 & .01 & 203 & 3 & 86.4 & 140 & 5 & .04 & 199 & 3 & .14 & 185 & 4 & 24 & 22 & 170 \\
\hline 260 & 6.0 & 2.03 & 98 & 7 & 3.46 & 153 & 5 & 36.7 & 176 & 4 & .03 & 203 & 3 & .09 & 202 & 3 & 18 & 22 & 171 \\
\hline 51 & 4.3 & .07 & 212 & 3 & 5.18 & 135 & 6 & 43.2 & 169 & 4 & .45 & 122 & 6 & .09 & 201 & 3 & 18 & 22 & 172 \\
\hline 167 & 3.5 & .10 & 197 & 3 & 4.56 & 142 & 5 & 16.8 & 205 & 3 & .43 & 124 & 6 & .40 & 151 & 5 & 5 & 22 & 173 \\
\hline 27 & 3.0 & .36 & 151 & 5 & 5.04 & 138 & 5 & 10.6 & 230 & 2 & .50 & 119 & 6 & .14 & 183 & 4 & 1 & 22 & 174 \\
\hline 218 & 5.6 & .27 & 161 & 5 & .01 & 202 & 3 & 265 & 96 & 7 & .06 & 188 & 4 & .01 & 241 & 2 & 33 & 21 & 175 \\
\hline 9 & 6.1 & 3.06 & 88 & 7 & .01 & 215 & 3 & 30.6 & 183 & 4 & .01 & 215 & 3 & .21 & 175 & 4 & 6.7 & 21 & 176 \\
\hline 269 & 3.7 & .02 & 241 & 2 & 4.61 & 141 & 5 & 56.5 & 156 & 5 & .69 & 108 & 7 & .03 & 228 & 2 & 4.8 & 21 & 177 \\
\hline 132 & 5.9 & .44 & 146 & 5 & 2.99 & 158 & 5 & 38.2 & 175 & 4 & .01 & 229 & 2 & .44 & 148 & 5 & 4.3 & 21 & 178 \\
\hline 25 & 5.9 & 3.18 & 87 & 7 & 4.68 & 140 & 5 & 19.7 & 200 & 3 & .01 & 237 & 2 & .19 & 177 & 4 & 3.9 & 21 & 179 \\
\hline 131 & 3.3 & .93 & 124 & 6 & 2.31 & 164 & 4 & 15.6 & 207 & 3 & .06 & 189 & 4 & .18 & 178 & 4 & 3.1 & 21 & 180 \\
\hline
\end{tabular}


Appendix 4. Prioritization index (PI) for all mine discharges-Continued

\begin{tabular}{|c|c|c|c|c|c|c|c|c|c|c|c|c|c|c|c|c|c|c|c|}
\hline $\begin{array}{c}\text { Site } \\
\text { number }\end{array}$ & $\begin{array}{c}\mathrm{pH} \\
\text { (units) }\end{array}$ & $\begin{array}{l}\text { Iron, } \\
\text { total } \\
(\mathrm{lb} / \mathrm{d} \\
\text { as } \mathrm{Fe})\end{array}$ & Rank & Score & $\begin{array}{c}\text { Acidity, } \\
\text { total } \\
\text { heated } \\
(\mathrm{lb} / \mathrm{d} \text { as } \\
\left.\mathrm{CaCO}_{3}\right)\end{array}$ & Rank & Score & $\begin{array}{c}\text { Sulfate, } \\
\text { total } \\
\text { (lb/d as } \\
\mathrm{CaCO}_{3} \text { ) }\end{array}$ & Rank & Score & $\begin{array}{c}\text { Aluminum, } \\
\text { dissolved } \\
\text { (lb/d } \\
\text { as } \mathrm{Al} \text { ) }\end{array}$ & Rank & Score & $\begin{array}{c}\text { Manganese, } \\
\text { total } \\
(\mathrm{lb} / \mathrm{d} \\
\text { as } \mathrm{Mn})\end{array}$ & Rank & Score & $\begin{array}{l}\text { Discharge, } \\
\text { instan- } \\
\text { taneous, } \\
\text { (gal/min) }\end{array}$ & $\begin{array}{l}\text { Final } \\
\text { score }\end{array}$ & PI \\
\hline 143 & 3.9 & $<0.01$ & 256 & 1 & 4.33 & 144 & 5 & 21.8 & 195 & 3 & 0.62 & 113 & 6 & 0.86 & 117 & 6 & 1.4 & 21 & 181 \\
\hline 250 & 3.1 & .16 & 183 & 4 & 3.02 & 157 & 5 & 26.9 & 189 & 4 & .27 & 140 & 5 & .06 & 212 & 3 & 1.4 & 21 & 182 \\
\hline 64 & 6.4 & .66 & 137 & 5 & .01 & 233 & 2 & 68.4 & 152 & 5 & .02 & 205 & 3 & .39 & 154 & 5 & 19 & 20 & 183 \\
\hline 37 & 3.6 & .09 & 203 & 3 & 2.94 & 159 & 5 & 21.2 & 198 & 3 & .19 & 150 & 5 & .25 & 171 & 4 & 6.8 & 20 & 184 \\
\hline 105 & 3.7 & .70 & 136 & 5 & 2.45 & 163 & 4 & 17.3 & 204 & 3 & .07 & 184 & 4 & .29 & 166 & 4 & 6 & 20 & 185 \\
\hline 53 & 3.6 & .07 & 210 & 3 & 3.97 & 149 & 5 & 28.2 & 188 & 4 & .43 & 125 & 6 & .04 & 223 & 2 & 4.6 & 20 & 186 \\
\hline 134 & 4.1 & .02 & 234 & 2 & 3.46 & 152 & 5 & 38.9 & 173 & 4 & .11 & 167 & 4 & .46 & 144 & 5 & 4 & 20 & 187 \\
\hline 57 & 5.5 & 2.50 & 91 & 7 & 3.92 & 150 & 5 & 12.1 & 225 & 2 & .01 & 245 & 1 & .38 & 156 & 5 & 1.6 & 20 & 188 \\
\hline 233 & 2.7 & .49 & 144 & 5 & 4.03 & 147 & 5 & 20.4 & 199 & 3 & .05 & 195 & 3 & .28 & 168 & 4 & 1 & 20 & 189 \\
\hline 252 & 3.3 & .05 & 221 & 2 & 3.07 & 156 & 5 & 19.2 & 201 & 3 & .36 & 133 & 6 & .12 & 186 & 4 & .8 & 20 & 190 \\
\hline 118 & 2.6 & .22 & 172 & 4 & 2.64 & 161 & 5 & 6.84 & 237 & 2 & .23 & 144 & 5 & .12 & 187 & 4 & .3 & 20 & 191 \\
\hline 197 & 7.2 & 1.37 & 113 & 6 & .01 & 268 & 1 & 180 & 109 & 6 & .09 & 173 & 4 & .06 & 217 & 2 & 60 & 19 & 192 \\
\hline 66 & 6.8 & .35 & 153 & 5 & .01 & 259 & 1 & 83.5 & 144 & 5 & .09 & 175 & 4 & .18 & 179 & 4 & 58 & 19 & 193 \\
\hline 229 & 6.2 & .63 & 138 & 5 & .01 & 217 & 2 & 97.9 & 136 & 5 & .04 & 200 & 3 & .11 & 189 & 4 & 24 & 19 & 194 \\
\hline 18 & 6.4 & .87 & 128 & 6 & .01 & 235 & 2 & 31.7 & 180 & 4 & .01 & 216 & 3 & .11 & 188 & 4 & 11 & 19 & 195 \\
\hline 226 & 5.5 & 1.44 & 109 & 6 & .01 & 200 & 3 & 15.3 & 210 & 3 & .01 & 219 & 2 & .48 & 141 & 5 & 7.5 & 19 & 196 \\
\hline 80 & 2.7 & .62 & 139 & 5 & 3.36 & 154 & 5 & 6.24 & 241 & 2 & .12 & 162 & 5 & .03 & 227 & 2 & .4 & 19 & 197 \\
\hline 65 & 5.8 & .12 & 190 & 3 & .01 & 204 & 3 & 97.4 & 137 & 5 & .09 & 174 & 4 & .08 & 203 & 3 & 58 & 18 & 198 \\
\hline 157 & 6.7 & .13 & 187 & 4 & .01 & 249 & 1 & 73.4 & 148 & 5 & .01 & 217 & 2 & .73 & 121 & 6 & 3.6 & 18 & 199 \\
\hline 168 & 6.0 & .91 & 127 & 6 & .52 & 180 & 4 & 18.5 & 202 & 3 & .01 & 242 & 2 & .09 & 195 & 3 & 2.3 & 18 & 200 \\
\hline 89 & 3.5 & .34 & 155 & 5 & 1.48 & 171 & 4 & 10.8 & 229 & 2 & .06 & 187 & 4 & .08 & 207 & 3 & 1.5 & 18 & 201 \\
\hline 108 & 7.0 & .07 & 213 & 3 & .01 & 262 & 1 & 310 & 90 & 7 & .09 & 172 & 4 & .03 & 225 & 2 & 60 & 17 & 202 \\
\hline 61 & 6.7 & 1.44 & 110 & 6 & .01 & 252 & 1 & 15.1 & 213 & 3 & .09 & 171 & 4 & .11 & 191 & 3 & 60 & 17 & 203 \\
\hline 106 & 7.1 & 1.22 & 115 & 6 & .01 & 264 & 1 & 3.06 & 253 & 1 & .08 & 179 & 4 & .39 & 155 & 5 & 51 & 17 & 204 \\
\hline 230 & 6.1 & .35 & 154 & 5 & .01 & 211 & 3 & 25.1 & 191 & 3 & .01 & 221 & 2 & .17 & 181 & 4 & 7.2 & 17 & 205 \\
\hline 263 & 6.5 & .92 & 126 & 6 & .01 & 239 & 2 & 52.4 & 165 & 4 & .01 & 231 & 2 & .10 & 193 & 3 & 4.8 & 17 & 206 \\
\hline 67 & 4.2 & .07 & 208 & 3 & .86 & 177 & 4 & 18.5 & 203 & 3 & .04 & 197 & 3 & .22 & 174 & 4 & 2 & 17 & 207 \\
\hline 90 & 2.9 & .11 & 193 & 3 & 2.83 & 160 & 5 & 12.8 & 219 & 2 & .17 & 155 & 5 & .03 & 230 & 2 & 1.9 & 17 & 208 \\
\hline 251 & 2.9 & .09 & 202 & 3 & 2.15 & 167 & 4 & 15.1 & 211 & 3 & .14 & 159 & 5 & .05 & 220 & 2 & .7 & 17 & 209 \\
\hline 270 & 6.6 & .11 & 194 & 3 & .01 & 245 & 1 & 298 & 92 & 7 & .12 & 163 & 4 & .01 & 246 & 1 & 80 & 16 & 210 \\
\hline
\end{tabular}


Appendix 4. Prioritization index (PI) for all mine discharges-Continued

\begin{tabular}{|c|c|c|c|c|c|c|c|c|c|c|c|c|c|c|c|c|c|c|c|}
\hline $\begin{array}{c}\text { Site } \\
\text { number }\end{array}$ & $\begin{array}{c}\mathrm{pH} \\
\text { (units) }\end{array}$ & $\begin{array}{l}\text { Iron, } \\
\text { total } \\
(\mathrm{lb} / \mathrm{d} \\
\text { as } \mathrm{Fe})\end{array}$ & Rank & Score & $\begin{array}{c}\text { Acidity, } \\
\text { total } \\
\text { heated } \\
(\mathrm{lb} / \mathrm{d} \text { as } \\
\left.\mathrm{CaCO}_{3}\right)\end{array}$ & Rank & Score & $\begin{array}{c}\text { Sulfate, } \\
\text { total } \\
\text { (lb/d as } \\
\mathrm{CaCO}_{3} \text { ) }\end{array}$ & Rank & Score & $\begin{array}{c}\text { Aluminum, } \\
\text { dissolved } \\
\text { (lb/d } \\
\text { as } \mathrm{Al} \text { ) }\end{array}$ & Rank & Score & $\begin{array}{c}\text { Manganese, } \\
\text { total } \\
(\mathrm{lb} / \mathrm{d} \\
\text { as } \mathrm{Mn})\end{array}$ & Rank & Score & $\begin{array}{c}\text { Discharge, } \\
\text { instan- } \\
\text { taneous, } \\
\text { (gal/min) }\end{array}$ & $\begin{array}{l}\text { Final } \\
\text { score }\end{array}$ & PI \\
\hline 238 & 5.3 & 0.01 & 246 & 1 & 4.03 & 148 & 5 & 119 & 125 & 6 & 0.04 & 198 & 3 & 0.01 & 244 & 1 & 14 & 16 & 211 \\
\hline 183 & 4.2 & .05 & 223 & 2 & 1.44 & 172 & 4 & 7.56 & 235 & 2 & .14 & 161 & 5 & .10 & 194 & 3 & 3 & 16 & 212 \\
\hline 265 & 6.3 & 1.04 & 121 & 6 & .46 & 182 & 4 & 6.91 & 236 & 2 & .01 & 250 & 1 & .08 & 206 & 3 & 1.2 & 16 & 213 \\
\hline 245 & 6.0 & .03 & 233 & 2 & .01 & 209 & 3 & 67.7 & 153 & 5 & .02 & 210 & 3 & .02 & 234 & 2 & 12 & 15 & 214 \\
\hline 107 & 5.2 & .05 & 220 & 2 & 2.10 & 168 & 4 & 36.4 & 177 & 4 & .03 & 202 & 3 & .03 & 226 & 2 & 9.2 & 15 & 215 \\
\hline 241 & 5.5 & .22 & 171 & 4 & .90 & 176 & 4 & 7.75 & 234 & 2 & .01 & 226 & 2 & .07 & 210 & 3 & 3.4 & 15 & 216 \\
\hline 262 & 6.4 & .31 & 159 & 5 & .14 & 193 & 3 & 6.84 & 238 & 2 & .01 & 238 & 2 & .09 & 199 & 3 & 3 & 15 & 217 \\
\hline 74 & 6.5 & .32 & 158 & 5 & .23 & 187 & 4 & 4.32 & 245 & 1 & .01 & 241 & 2 & .11 & 190 & 3 & 2.4 & 15 & 218 \\
\hline 43 & 3.5 & .16 & 181 & 4 & .83 & 178 & 4 & 2.16 & 257 & 1 & .05 & 196 & 3 & .06 & 214 & 3 & .5 & 15 & 219 \\
\hline 102 & 4.7 & .01 & 248 & 1 & 2.16 & 166 & 4 & 14.6 & 216 & 3 & .06 & 190 & 3 & .08 & 204 & 3 & 15 & 14 & 220 \\
\hline 98 & 6.1 & .26 & 163 & 4 & .01 & 214 & 3 & 13.5 & 218 & 2 & .01 & 240 & 2 & .06 & 215 & 3 & 2.4 & 14 & 221 \\
\hline 254 & 3.4 & .05 & 225 & 2 & 1.20 & 173 & 4 & 11.4 & 226 & 2 & .09 & 177 & 4 & .02 & 233 & 2 & 1 & 14 & 222 \\
\hline 86 & 6.6 & .07 & 211 & 3 & .01 & 240 & 2 & 15.1 & 212 & 3 & .01 & 214 & 3 & .05 & 219 & 2 & 9 & 13 & 223 \\
\hline 200 & 4.6 & .02 & 237 & 2 & 2.16 & 165 & 4 & 12.6 & 221 & 2 & .05 & 191 & 3 & .05 & 222 & 2 & 7.5 & 13 & 224 \\
\hline 145 & 6.2 & .01 & 260 & 1 & .01 & 219 & 2 & 118 & 127 & 6 & .01 & 228 & 2 & .02 & 235 & 2 & 4.9 & 13 & 225 \\
\hline 68 & 6.7 & .01 & 253 & 1 & .01 & 253 & 1 & 105 & 129 & 6 & .01 & 234 & 2 & .08 & 208 & 3 & 4.6 & 13 & 226 \\
\hline 85 & 4.6 & .06 & 217 & 2 & .33 & 184 & 4 & 8.40 & 232 & 2 & .01 & 239 & 2 & .08 & 205 & 3 & 2.5 & 13 & 227 \\
\hline 93 & 3.6 & .01 & 244 & 1 & .90 & 175 & 4 & 12.1 & 224 & 2 & .03 & 204 & 3 & .06 & 211 & 3 & 2.2 & 13 & 228 \\
\hline 87 & 6.4 & .24 & 168 & 4 & .01 & 230 & 2 & 12.7 & 220 & 2 & .01 & 243 & 2 & .09 & 197 & 3 & 1.8 & 13 & 229 \\
\hline 92 & 5.8 & .02 & 240 & 2 & .24 & 186 & 4 & 22.4 & 194 & 3 & .01 & 236 & 2 & .02 & 232 & 2 & 1.7 & 13 & 230 \\
\hline 84 & 6.1 & .24 & 165 & 4 & .01 & 213 & 3 & 12.6 & 222 & 2 & .01 & 259 & 1 & .06 & 213 & 3 & .5 & 13 & 231 \\
\hline 133 & 3.8 & .01 & 263 & 1 & .73 & 179 & 4 & 5.28 & 242 & 2 & .05 & 193 & 3 & .08 & 209 & 3 & .4 & 13 & 232 \\
\hline 136 & 6.6 & .16 & 182 & 4 & .01 & 241 & 2 & 5.22 & 243 & 2 & .01 & 220 & 2 & .02 & 237 & 2 & 7.5 & 12 & 233 \\
\hline 264 & 6.4 & .06 & 218 & 2 & .01 & 232 & 2 & 26.9 & 190 & 3 & .01 & 246 & 1 & .27 & 170 & 4 & 1.6 & 12 & 234 \\
\hline 182 & 5.2 & .18 & 177 & 4 & .20 & 189 & 4 & 1.44 & 261 & 1 & .01 & 255 & 1 & .03 & 231 & 2 & 1 & 12 & 235 \\
\hline 69 & 3.7 & .01 & 262 & 1 & .91 & 174 & 4 & 4.18 & 246 & 1 & .11 & 165 & 4 & .05 & 221 & 2 & .4 & 12 & 236 \\
\hline 99 & 6.2 & .10 & 201 & 3 & .12 & 194 & 3 & 6.72 & 239 & 2 & .01 & 263 & 1 & .06 & 216 & 3 & .4 & 12 & 237 \\
\hline 228 & 5.5 & .26 & 162 & 5 & .39 & 183 & 4 & 1.56 & 260 & 1 & .01 & 262 & 1 & .01 & 245 & 1 & .1 & 12 & 238 \\
\hline 243 & 6.3 & .19 & 176 & 4 & .01 & 224 & 2 & 12.3 & 223 & 2 & .01 & 218 & 2 & .01 & 251 & 1 & 7.9 & 11 & 239 \\
\hline 246 & 6.4 & .01 & 266 & 1 & .01 & 234 & 2 & 32.3 & 179 & 4 & .01 & 233 & 2 & .01 & 243 & 2 & 3.9 & 11 & 240 \\
\hline
\end{tabular}


Appendix 4. Prioritization index (PI) for all mine discharges-Continued

\begin{tabular}{|c|c|c|c|c|c|c|c|c|c|c|c|c|c|c|c|c|c|c|c|}
\hline $\begin{array}{c}\text { Site } \\
\text { number }\end{array}$ & $\begin{array}{c}\mathrm{pH} \\
\text { (units) }\end{array}$ & $\begin{array}{l}\text { Iron, } \\
\text { total } \\
(\mathrm{lb} / \mathrm{d} \\
\text { as } \mathrm{Fe})\end{array}$ & Rank & Score & $\begin{array}{c}\text { Acidity, } \\
\text { total } \\
\text { heated } \\
(\mathrm{lb} / \mathrm{d} \text { as } \\
\left.\mathrm{CaCO}_{3}\right)\end{array}$ & Rank & Score & $\begin{array}{c}\text { Sulfate, } \\
\text { total } \\
\text { (lb/d as } \\
\mathrm{CaCO}_{3} \text { ) }\end{array}$ & Rank & Score & $\begin{array}{c}\text { Aluminum, } \\
\text { dissolved } \\
\text { (lb/d } \\
\text { as } \mathrm{Al} \text { ) }\end{array}$ & Rank & Score & $\begin{array}{c}\text { Manganese, } \\
\text { total } \\
(\mathrm{lb} / \mathrm{d} \\
\text { as } \mathrm{Mn})\end{array}$ & Rank & Score & $\begin{array}{c}\text { Discharge, } \\
\text { instan- } \\
\text { taneous, } \\
\text { (gal/min) }\end{array}$ & $\begin{array}{l}\text { Final } \\
\text { score }\end{array}$ & PI \\
\hline 49 & 6.7 & 0.20 & 174 & 4 & $<0.01$ & 250 & 1 & 11.0 & 228 & 2 & $<0.01$ & 235 & 2 & 0.03 & 224 & 2 & 3.4 & 11 & 241 \\
\hline 198 & 4.0 & .01 & 243 & 2 & .28 & 185 & 4 & 1.33 & 262 & 1 & .04 & 201 & 3 & $<.01$ & 256 & 1 & .3 & 11 & 242 \\
\hline 148 & 6.3 & .24 & 166 & 4 & .22 & 188 & 4 & 2.64 & 254 & 1 & $<.01$ & 269 & 1 & $<.01$ & 250 & 1 & .2 & 11 & 243 \\
\hline 196 & 6.8 & $<.01$ & 259 & 1 & $<.01$ & 258 & 1 & 31.7 & 181 & 4 & .02 & 212 & 3 & $<.01$ & 262 & 1 & 12 & 10 & 244 \\
\hline 119 & 5.0 & $<.01$ & 252 & 1 & 1.54 & 170 & 4 & 3.55 & 252 & 1 & $<.01$ & 232 & 2 & .02 & 236 & 2 & 4 & 10 & 245 \\
\hline 201 & 4.2 & $<.01$ & 255 & 1 & .50 & 181 & 4 & 2.11 & 258 & 1 & .01 & 223 & 2 & .01 & 242 & 2 & 1.6 & 10 & 246 \\
\hline 150 & 7.3 & .08 & 207 & 3 & $<.01$ & 269 & 1 & 15.6 & 208 & 3 & $<.01$ & 253 & 1 & .01 & 240 & 2 & 1 & 10 & 247 \\
\hline 83 & 4.5 & $<.01$ & 257 & 1 & .17 & 192 & 3 & 14.4 & 217 & 2 & .01 & 224 & 2 & .01 & 238 & 2 & .8 & 10 & 248 \\
\hline 237 & 3.6 & .12 & 189 & 4 & .20 & 190 & 3 & 1.73 & 259 & 1 & $<.01$ & 266 & 1 & $<.01$ & 252 & 1 & .2 & 10 & 249 \\
\hline 203 & 3.8 & $<.01$ & 249 & 1 & .19 & 191 & 3 & 2.52 & 255 & 1 & .02 & 208 & 3 & .03 & 229 & 2 & .1 & 10 & 250 \\
\hline 206 & 7.1 & .04 & 229 & 2 & $<.01$ & 266 & 1 & 15.6 & 209 & 3 & .01 & 222 & 2 & $<.01$ & 258 & 1 & 7.2 & 9 & 251 \\
\hline 147 & 6.8 & .49 & 145 & 5 & $<.01$ & 254 & 1 & 3.66 & 251 & 1 & $<.01$ & 260 & 1 & $<.01$ & 247 & 1 & .5 & 9 & 252 \\
\hline 244 & 6.3 & .01 & 245 & 1 & $<.01$ & 222 & 2 & 6.34 & 240 & 2 & $<.01$ & 230 & 2 & $<.01$ & 265 & 1 & 4.8 & 8 & 253 \\
\hline 267 & 6.6 & .07 & 209 & 3 & $<.01$ & 246 & 1 & .02 & 270 & 1 & $<.01$ & 264 & 1 & .01 & 239 & 2 & .4 & 8 & 254 \\
\hline 52 & 3.8 & .02 & 236 & 2 & .12 & 195 & 3 & 1.32 & 263 & 1 & $<.01$ & 248 & 1 & $<.01$ & 248 & 1 & .2 & 8 & 255 \\
\hline 239 & 6.0 & .05 & 222 & 2 & .02 & 198 & 3 & .11 & 269 & 1 & .01 & 270 & 1 & .01 & 261 & 1 & .1 & 8 & 256 \\
\hline 195 & 7.1 & .01 & 250 & 1 & .01 & 263 & 1 & 9.22 & 231 & 2 & .01 & 227 & 2 & .01 & 267 & 1 & 6.4 & 7 & 257 \\
\hline 193 & 6.9 & .03 & 230 & 2 & .01 & 261 & 1 & 11.3 & 227 & 2 & .01 & 244 & 1 & .01 & 253 & 1 & 2 & 7 & 258 \\
\hline 222 & 5.6 & .01 & 268 & 1 & .01 & 201 & 3 & 4.18 & 247 & 1 & .01 & 249 & 1 & .01 & 268 & 1 & 1.2 & 7 & 259 \\
\hline 146 & 6.7 & .02 & 239 & 2 & .01 & 248 & 1 & 7.92 & 233 & 2 & .01 & 252 & 1 & .01 & 259 & 1 & 1.1 & 7 & 260 \\
\hline 256 & 5.8 & .01 & 258 & 1 & .05 & 196 & 3 & 30 & 268 & 1 & .01 & 257 & 1 & .01 & 257 & 1 & .8 & 7 & 261 \\
\hline 266 & 6.8 & .06 & 214 & 3 & .01 & 257 & 1 & 4.61 & 244 & 1 & .01 & 258 & 1 & .01 & 254 & 1 & .8 & 7 & 262 \\
\hline 240 & 5.8 & .01 & 247 & 1 & .03 & 197 & 3 & .98 & 265 & 1 & .01 & 268 & 1 & .01 & 249 & 1 & .2 & 7 & 263 \\
\hline 88 & 6.5 & .01 & 269 & 1 & .01 & 237 & 2 & 3.74 & 250 & 1 & .01 & 251 & 1 & .01 & 266 & 1 & 1.2 & 6 & 264 \\
\hline 153 & 6.3 & $<.01$ & 267 & 1 & $<.01$ & 225 & 2 & 1.19 & 264 & 1 & $<.01$ & 265 & 1 & $<.01$ & 263 & 1 & 0.3 & 6 & 265 \\
\hline 91 & 6.8 & $<.01$ & 264 & 1 & $<.01$ & 256 & 1 & 4.14 & 248 & 1 & $<.01$ & 247 & 1 & $<.01$ & 260 & 1 & 1.5 & 5 & 266 \\
\hline 257 & 6.9 & $<.01$ & 251 & 1 & $<.01$ & 260 & 1 & 4.09 & 249 & 1 & $<.01$ & 254 & 1 & $<.01$ & 269 & 1 & 1.1 & 5 & 267 \\
\hline 50 & 7.1 & $<.01$ & 261 & 1 & $<.01$ & 267 & 1 & 2.40 & 256 & 1 & $<.01$ & 256 & 1 & $<.01$ & 270 & 1 & 1 & 5 & 268 \\
\hline 199 & 7.1 & $<.01$ & 265 & 1 & $<.01$ & 265 & 1 & 0.96 & 266 & 1 & $<.01$ & 261 & 1 & $<.01$ & 264 & 1 & 0.5 & 5 & 269 \\
\hline 45 & 9.7 & $<.01$ & 270 & 1 & $<.01$ & 270 & 1 & 0.41 & 267 & 1 & $<.01$ & 267 & 1 & $<.01$ & 255 & 1 & 0.04 & 5 & 270 \\
\hline
\end{tabular}




\section{Appendix 5. Field data and laboratory analyses for surface-water sites}

$\left[\mathrm{ft}^{3} / \mathrm{s}\right.$, cubic foot per second; ${ }^{\circ} \mathrm{C}$, degrees Celsius; $\mu \mathrm{S} / \mathrm{cm}$, microsiemen per centimeter at 25 degrees Celsius; $\mathrm{mg} / \mathrm{L}$, milligram per liter; ug/L, micrograms per liter; <, less than; --, no data available]

\begin{tabular}{|c|c|c|c|c|c|c|c|c|c|}
\hline Date & Time & $\begin{array}{c}\text { Discharge, } \\
\text { instantaneous } \\
\left(\mathrm{ft}^{3} / \mathrm{s}\right)\end{array}$ & $\begin{array}{l}\text { Temperature, } \\
\text { water } \\
\left({ }^{\circ} \mathrm{C}\right)\end{array}$ & $\begin{array}{c}\text { Specific } \\
\text { conductance } \\
(\mu \mathrm{S} / \mathrm{cm})\end{array}$ & $\begin{array}{c}\mathrm{pH} \\
\text { (standard } \\
\text { units) }\end{array}$ & $\begin{array}{c}\text { Alkalinity, } \\
\text { total } \\
(\mathrm{mg} / \mathrm{L} \text { as } \\
\left.\mathrm{CaCO}_{3}\right)\end{array}$ & $\begin{array}{c}\text { Residue } \\
\text { at } 105^{\circ} \mathrm{C} \text {, } \\
\text { dissolved } \\
(\mathrm{mg} / \mathrm{L})\end{array}$ & $\begin{array}{c}\text { Carbon, } \\
\text { inorganic, } \\
\text { total } \\
(\mathrm{mg} / \mathrm{L} \\
\text { as C) }\end{array}$ & $\begin{array}{c}\text { Sulfate, } \\
\text { total } \\
(\mathrm{mg} / \mathrm{L} \\
\left.\text { as } \mathrm{SO}_{4}\right)\end{array}$ \\
\hline \multicolumn{10}{|c|}{03039200 Clear Run near Buckstown, Pa., Site 808 (LAT 4002 49N LONG 07850 00W) } \\
\hline September 1, 1992 & 1510 & 1.8 & 15.0 & 1,200 & 6.7 & 42 & 982 & 9.2 & 600 \\
\hline July 27,1993 & 1715 & .78 & 21.5 & 2,320 & 6.2 & 50 & 1,770 & 8.2 & 1,200 \\
\hline May 23, 1994 & 1820 & 3.2 & 15.0 & 620 & 6.0 & 26 & 490 & 5.5 & 280 \\
\hline \multicolumn{10}{|c|}{03039300 Wells Creek at Mostoller, Pa., Site 813 (LAT 4004 11N LONG 07856 45W) } \\
\hline September 2, 1992 & 0820 & 2.6 & 12.0 & 665 & 6.1 & 15 & 564 & 3.1 & 200 \\
\hline July 27, 1993 & 1015 & 3.9 & 19.5 & 689 & 4.8 & 2 & 556 & $<1.0$ & 330 \\
\hline May 24, 1994 & 0840 & 12 & 13.0 & 385 & 5.9 & 3 & -- & $<1.0$ & 160 \\
\hline \multicolumn{10}{|c|}{03039340 Beaverdam Creek at Stoystown, Pa., Site 814 (LAT 4005 35N LONG 07857 16W) } \\
\hline September 2, 1992 & 0910 & 2.5 & 12.5 & 397 & 6.4 & 96 & 336 & 19 & 79 \\
\hline July 27, 1993 & 0845 & 2.3 & 19.5 & 460 & 7.7 & 100 & 336 & 25 & 100 \\
\hline May 24, 1994 & 0930 & 9.9 & 14.0 & 311 & 7.4 & 66 & 216 & 6.9 & 71 \\
\hline \multicolumn{10}{|c|}{03039440 Quemahoning Creek at Boswell, Pa., Site 818 (LAT 4009 54N LONG 07901 51W) } \\
\hline September 1, 1992 & 1130 & 19 & 15.0 & 400 & 6.1 & 34 & 362 & 9.6 & 140 \\
\hline July 28, 1993 & 1130 & 10 & 20.0 & 650 & 5.8 & 42 & 504 & 14 & 280 \\
\hline May 23, 1994 & 1150 & 67 & 16.0 & 290 & 6.6 & 20 & 246 & 4.7 & 100 \\
\hline \multicolumn{10}{|c|}{03039700 Dark Shade Creek at Central City, Pa., Site 824 (LAT 4006 18N LONG 07847 55W) } \\
\hline September 1, 1992 & 1610 & 3.1 & 18.5 & 209 & 3.8 & 0 & 140 & $<1.0$ & 65 \\
\hline July 28, 1993 & 1315 & 1.4 & 23.5 & 231 & 3.7 & 0 & 152 & $<1.0$ & 160 \\
\hline May 23, 1994 & 1435 & 13 & 16.5 & 125 & 4.1 & 0 & 94 & $<1.0$ & 45 \\
\hline \multicolumn{10}{|c|}{03039750 Dark Shade Creek at Reitz, Pa., Site 826 (LAT 4008 03N LONG 07848 53W) } \\
\hline September 2, 1992 & 0815 & 21 & 11.0 & 682 & 3.8 & 0 & 612 & 1.6 & 350 \\
\hline July 28, 1993 & 1015 & 13 & 15.0 & 1,130 & 3.3 & 0 & 990 & 1.4 & 770 \\
\hline May 23, 1994 & 1050 & 53 & 13.0 & 550 & 3.8 & 0 & 468 & 2.6 & 330 \\
\hline \multicolumn{10}{|c|}{03039920 Little Paint Creek at Scalp Level, Pa., Site 829 (LAT 4014 46N LONG 07850 49W) } \\
\hline September 1, 1992 & 1450 & 1.9 & 23.5 & 410 & 5.5 & 4 & 360 & $<1.0$ & 170 \\
\hline July 28, 1993 & 1820 & 1.1 & 28.5 & 490 & 5.7 & 2 & 426 & $<1.0$ & 260 \\
\hline May 24, 1994 & 0915 & 10 & 13.0 & 236 & 6.7 & 7 & 200 & 2.3 & 87 \\
\hline \multicolumn{10}{|c|}{03039925 North Fork Bens Creek at North Fork, Pa., Site 833 (LAT 4015 58N LONG $0790101 \mathrm{~W}$ ) } \\
\hline September 1, 1992 & 0910 & 1.3 & 13.0 & 61 & 6.7 & 3 & 90 & $<1.0$ & 9.0 \\
\hline July 27, 1993 & 1350 & .86 & 18.0 & 64 & 7.0 & 3 & 78 & $<1.0$ & 7.7 \\
\hline May 23, 1994 & 1215 & 6.4 & 11.5 & 50 & 6.9 & 3 & 58 & $<1.0$ & 9.2 \\
\hline \multicolumn{10}{|c|}{03039930 South Fork Bens Creek near Thomasdale, Pa., Site 831 (LAT 4013 41N LONG 07902 49W) } \\
\hline September 1, 1992 & 0805 & 8.9 & 13.0 & 44 & 6.4 & 8 & 80 & 1.5 & 8.0 \\
\hline July 27, 1993 & 1250 & 3.5 & 19.0 & 490 & 7.2 & 7 & 88 & 1.8 & 7.7 \\
\hline May 23, 1994 & 1015 & 7.7 & 11.5 & 330 & 5.8 & 4 & 52 & $<1.0$ & 8.0 \\
\hline \multicolumn{10}{|c|}{03039950 South Fork Bens Creek near Ferndale, Pa., Site 832 (LAT 4015 02N LONG 07858 20W) } \\
\hline September 1, 1992 & 1015 & 7.0 & 13.5 & 773 & 5.6 & 92 & 668 & 19 & 320 \\
\hline July 27, 1993 & 1035 & 6.6 & 18.0 & 840 & 7.3 & 100 & 654 & 23 & 320 \\
\hline May 23, 1994 & 1430 & 33 & 16.0 & 383 & 6.9 & 46 & 312 & 10 & 140 \\
\hline
\end{tabular}


Appendix 5. Field data and laboratory analyses for surface-water sites-Continued

$\left[\mathrm{ft}^{3} / \mathrm{s}\right.$, cubic foot per second; ${ }^{\circ} \mathrm{C}$, degrees Celsius; $\mu \mathrm{S} / \mathrm{cm}$, microsiemen per centimeter at 25 degrees Celsius; $\mathrm{mg} / \mathrm{L}$, milligram per liter; ug/L, micrograms per liter; <, less than; --, no data available]

\begin{tabular}{|c|c|c|c|c|c|c|c|c|c|}
\hline Date & $\begin{array}{c}\text { Fluoride, } \\
\text { total } \\
\text { (mg/L } \\
\text { as F) }\end{array}$ & $\begin{array}{c}\text { Iron, total } \\
\text { recoverable } \\
(\mu \mathrm{g} / \mathrm{L} \\
\text { as Fe })\end{array}$ & $\begin{array}{c}\text { Iron, } \\
\text { dissolved } \\
(\mu \mathrm{g} / \mathrm{L} \\
\text { as Fe })\end{array}$ & $\begin{array}{c}\text { Manganese, } \\
\text { total } \\
\text { recoverable } \\
(\mu \mathrm{g} / \mathrm{L} \\
\text { as } \mathrm{Mn})\end{array}$ & $\begin{array}{l}\text { Manganese, } \\
\text { dissolved } \\
(\mu \mathrm{g} / \mathrm{L} \\
\text { as } \mathrm{Mn})\end{array}$ & $\begin{array}{c}\text { Aluminum, } \\
\text { total } \\
\text { recoverable } \\
(\mu \mathrm{g} / \mathrm{L} \\
\text { as } \mathrm{Al})\end{array}$ & $\begin{array}{l}\text { Aluminum, } \\
\text { dissolved } \\
(\mu \mathrm{g} / \mathrm{L} \\
\text { as Al }\end{array}$ & $\begin{array}{l}\text { Acidity, } \\
\text { total } \\
\text { heated } \\
(\mathrm{mg} / \mathrm{L} \text { as } \\
\left.\mathrm{CaCO}_{3}\right)\end{array}$ & $\begin{array}{l}\text { Acidity, } \\
\text { mineral } \\
\text { (methyl } \\
\text { orange) } \\
(\mathrm{mg} / \mathrm{L} \text { as } \\
\left.\mathrm{CaCO}_{3}\right)\end{array}$ \\
\hline \multicolumn{10}{|c|}{03039200 Clear Run near Buckstown, Pa., Site 808 (LAT 4002 49N LONG 07850 00W) } \\
\hline September 1, 1992 & $<0.2$ & 1,800 & 150 & 290 & 200 & 940 & $<130$ & 0 & 0 \\
\hline July 27, 1993 & $<.2$ & 6,100 & 4,800 & 600 & 600 & 140 & $<130$ & 0 & -- \\
\hline May 23, 1994 & $<.2$ & 360 & 120 & 610 & 560 & 370 & 300 & 0 & -- \\
\hline \multicolumn{10}{|c|}{03039300 Wells Creek at Mostoller, Pa., Site 813 (LAT 4004 11N LONG 07856 45W) } \\
\hline September 2, 1992 & $<.2$ & 320 & 31 & 800 & 780 & $<130$ & $<130$ & 0 & 0 \\
\hline July 27, 1993 & $<.2$ & 240 & 90 & 1,900 & 1,900 & 1,400 & 1,400 & 14 & -- \\
\hline May 24, 1994 & $<.2$ & 770 & 150 & 1,000 & 950 & 1,000 & 150 & 5.2 & -- \\
\hline \multicolumn{10}{|c|}{03039340 Beaverdam Creek at Stoystown, Pa., Site 814 (LAT 4005 35N LONG 07857 16W) } \\
\hline September 2, 1992 & $<.2$ & 430 & 78 & 41 & 23 & 220 & $<130$ & 0 & 0 \\
\hline July 27,1993 & $<.2$ & 360 & 20 & 70 & 50 & 400 & 400 & 0 & -- \\
\hline May 24, 1994 & $<.2$ & 460 & 24 & 47 & 31 & $<130$ & $<130$ & 0 & -- \\
\hline \multicolumn{10}{|c|}{03039440 Quemahoning Creek at Boswell, Pa., Site 818 (LAT 4009 54N LONG 07901 51W) } \\
\hline September 1, 1992 & $<.2$ & 3,300 & 2,400 & 720 & 720 & $<130$ & $<130$ & 0 & 0 \\
\hline July 28, 1993 & $<.2$ & 4,500 & 2,700 & 1,700 & 1,600 & 190 & $<130$ & 0 & -- \\
\hline May 23, 1994 & $<.2$ & 3,100 & 2,100 & 940 & 900 & $<130$ & $<130$ & 0 & -- \\
\hline \multicolumn{10}{|c|}{03039700 Dark Shade Creek at Central City, Pa., Site 824 (LAT 4006 18N LONG 07847 55W) } \\
\hline September 1, 1992 & $<.2$ & 1,500 & 1,400 & 530 & 530 & 2,500 & 2,500 & 34 & 3 \\
\hline July 28, 1993 & $<.2$ & 1,000 & 980 & 680 & 660 & 3,000 & 3,000 & 36 & 4 \\
\hline May 23, 1994 & $<.2$ & 1,000 & 980 & 320 & 330 & 1,800 & 1,800 & 22 & 0 \\
\hline \multicolumn{10}{|c|}{03039750 Dark Shade Creek at Reitz, Pa., Site 826 (LAT 4008 03N LONG 07848 53W) } \\
\hline September 2, 1992 & .3 & 18,000 & 16,000 & 3,100 & 3,100 & 4,900 & 4,600 & 70 & 8 \\
\hline July 28, 1993 & .2 & 24,000 & 21,000 & 5,000 & 4,900 & 8,800 & 8,600 & 120 & 42 \\
\hline May 23, 1994 & .2 & 8,300 & 5,500 & 2,500 & 2,400 & 4,400 & 4,100 & 54 & 4 \\
\hline \multicolumn{10}{|c|}{03039920 Little Paint Creek at Scalp Level, Pa., Site 829 (LAT 4014 46N LONG 07850 49W) } \\
\hline September 1, 1992 & $<.2$ & 6,100 & 1,600 & 410 & 360 & 7,100 & $<130$ & 12 & 0 \\
\hline July 28, 1993 & $<.2$ & 7,600 & 5,300 & 460 & 450 & 3,600 & 200 & 19 & -- \\
\hline May 24, 1994 & $<.2$ & 8,700 & 6,300 & 200 & 220 & 3,700 & 510 & 15 & -- \\
\hline \multicolumn{10}{|c|}{03039925 North Fork Bens Creek at North Fork, Pa., Site 833 (LAT 4015 58N LONG $0790101 \mathrm{~W}$ ) } \\
\hline September 1, 1992 & $<.2$ & 20 & $<10$ & $<10$ & $<10$ & $<130$ & $<130$ & 6.0 & 0 \\
\hline July 27, 1993 & $<.2$ & 2,300 & 20 & 460 & $<50$ & 3,100 & $<130$ & 2.4 & -- \\
\hline May 23, 1994 & $<.2$ & 30 & $<10$ & 32 & 22 & $<130$ & $<130$ & 5.6 & -- \\
\hline \multicolumn{10}{|c|}{03039930 South Fork Bens Creek near Thomasdale, Pa., Site 831 (LAT 4013 41N LONG 07902 49W) } \\
\hline September 1, 1992 & $<.2$ & 190 & $<10$ & 29 & $<10$ & 180 & $<130$ & 2.4 & 0 \\
\hline July 27, 1993 & $<.2$ & 2,300 & 50 & 280 & 210 & 1,900 & 200 & 0 & -- \\
\hline May 23, 1994 & $<.2$ & 110 & 20 & 25 & 16 & $<130$ & 130 & 5.0 & -- \\
\hline \multicolumn{10}{|c|}{03039950 South Fork Bens Creek near Ferndale, Pa., Site 832 (LAT 4015 02N LONG 07858 20W) } \\
\hline September 1, 1992 & $<.2$ & 900 & $<10$ & 230 & 230 & 370 & $<130$ & 0 & 0 \\
\hline July 27, 1993 & .2 & 950 & 490 & -- & -- & -- & -- & 0 & -- \\
\hline May 23, 1994 & $<.2$ & 1,300 & 120 & 200 & 200 & 510 & $<130$ & 0 & -- \\
\hline
\end{tabular}




\begin{tabular}{|c|c|c|c|c|c|c|c|c|c|}
\hline Date & Time & $\begin{array}{c}\text { Discharge, } \\
\text { instantaneous } \\
\left(\mathrm{ft}^{3} / \mathrm{s}\right)\end{array}$ & $\begin{array}{c}\text { Temperature, } \\
\text { water } \\
\left({ }^{\circ} \mathrm{C}\right)\end{array}$ & $\begin{array}{c}\text { Specific } \\
\text { conductance } \\
(\mu \mathrm{S} / \mathrm{cm})\end{array}$ & $\begin{array}{c}\mathrm{pH} \\
\text { (standard } \\
\text { units) }\end{array}$ & $\begin{array}{c}\text { Alkalinity, } \\
\text { total } \\
(\mathrm{mg} / \mathrm{L} \text { as } \\
\mathrm{CaCO}_{3} \text { ) }\end{array}$ & $\begin{array}{c}\text { Residue } \\
\text { at } 105^{\circ} \mathrm{C} \text {, } \\
\text { dissolved } \\
(\mathrm{mg} / \mathrm{L})\end{array}$ & $\begin{array}{c}\text { Carbon, } \\
\text { inorganic, } \\
\text { total } \\
(\mathrm{mg} / \mathrm{L} \\
\text { as C) }\end{array}$ & $\begin{array}{c}\text { Sulfate, } \\
\text { total } \\
(\mathrm{mg} / \mathrm{L} \\
\left.\text { as } \mathrm{SO}_{4}\right)\end{array}$ \\
\hline \multicolumn{10}{|c|}{03039957 Bens Creek at Ferndale, Pa., Site 834 (LAT 4016 58N LONG 07856 10W) } \\
\hline September 1, 1992 & 1120 & 10 & 15.5 & 525 & 6.1 & 66 & 454 & 14 & 190 \\
\hline July 28, 1993 & 1245 & 8.0 & 23.5 & 630 & 7.4 & 76 & 478 & 16 & 230 \\
\hline May 23, 1994 & 1615 & 58 & 17.5 & 260 & 7.8 & 32 & 226 & 11 & 85 \\
\hline \multicolumn{10}{|c|}{03040000 Stonycreek River at Ferndale, Pa., Site 805 (LAT $401708 \mathrm{~N}$ LONG 07855 15W) } \\
\hline September 1, 1992 & 1140 & 198 & 19.5 & 498 & 5.4 & 2 & 414 & $<1.0$ & 240 \\
\hline July 27, 1993 & 0920 & 127 & 23.0 & 820 & 4.2 & 0 & 802 & $<1.0$ & 470 \\
\hline May 23, 1994 & 1700 & 541 & 19.5 & 411 & 4.8 & 2 & 362 & $<1.0$ & 190 \\
\hline \multicolumn{10}{|c|}{395836078554901 Glades Creek near Shanksville, Pa., Site 806 (LAT 3958 36N LONG 07855 49W) } \\
\hline September 1, 1992 & 0740 & 3.2 & 13.0 & 554 & 6.9 & 74 & 428 & 15 & 160 \\
\hline July 27, 1993 & 0810 & 3.9 & 19.5 & 761 & 6.7 & 100 & 678 & 20 & 250 \\
\hline May 24, 1994 & 1325 & 6.6 & 18.0 & 588 & 6.1 & 66 & 500 & 14 & 190 \\
\hline \multicolumn{10}{|c|}{400014078540201 Stonycreek River at Shanksville, Pa., Site 801 (LAT 4000 14N LONG $0785402 W$ ) } \\
\hline September 1, 1992 & 0850 & 11 & 16.0 & 557 & 6.8 & 58 & 532 & 10 & 190 \\
\hline July 27, 1993 & 1245 & 11 & 23.5 & 740 & 6.8 & 100 & 596 & 19 & 220 \\
\hline May 24, 1994 & 1225 & 21 & 18.0 & 446 & 6.4 & 50 & 360 & 11 & 140 \\
\hline \multicolumn{10}{|c|}{400033078511601 Boone Run near Shanksville, Pa., Site 807 (LAT 4000 33N LONG 07851 16W) } \\
\hline September 1, 1992 & 1400 & 3.2 & 15.0 & 161 & 6.8 & 5 & 134 & 1.3 & 61 \\
\hline July 27, 1993 & 1400 & .84 & 22.5 & 490 & 5.0 & 10 & 506 & 2.7 & 270 \\
\hline May 23, 1994 & 1900 & 5.1 & 14.5 & 141 & 6.0 & 2 & 134 & 1.0 & 60 \\
\hline \multicolumn{10}{|c|}{400056078540501 Rhoads Creek at Shanksville, Pa., Site 810 (LAT 4000 56N LONG 07854 05W) } \\
\hline September 1, 1992 & 1030 & 14 & 18.5 & 610 & 6.8 & 24 & 540 & 5.1 & 280 \\
\hline July 27, 1993 & 1110 & 2.5 & 22.5 & 535 & 6.3 & 48 & 538 & 6.4 & 230 \\
\hline May 24, 1994 & 1045 & 23 & 16.5 & 412 & 6.6 & 15 & 352 & 3.4 & 170 \\
\hline \multicolumn{10}{|c|}{400058078552301 Schrock Run near Shanksville, Pa., Site 811 (LAT 4000 58N LONG 07855 23W) } \\
\hline September 1, 1992 & 0945 & 2.2 & 12.5 & 1,220 & 6.8 & 64 & 1,010 & 15 & 610 \\
\hline July 27, 1993 & 0950 & 1.3 & 19.5 & 1,390 & 5.8 & 28 & 1,110 & 9.1 & 730 \\
\hline May 24, 1994 & 1135 & 3.4 & 15.0 & 825 & 6.4 & 26 & 684 & 6.8 & 440 \\
\hline \multicolumn{10}{|c|}{400337078513701 Calendars Run at Buckstown, Pa., Site 809 (LAT 4003 37N LONG 07851 37W) } \\
\hline September 1, 1992 & 1300 & .11 & 13.0 & 224 & 7.1 & 30 & 180 & 3.6 & 30 \\
\hline July 28, 1993 & 1440 & $<.01$ & 18.5 & 250 & 6.1 & 20 & 190 & 5.3 & 19 \\
\hline May 23, 1994 & 1715 & .87 & 15.5 & 160 & 7.1 & 10 & 144 & 2.1 & 40 \\
\hline \multicolumn{10}{|c|}{400414078545101 Lamberts Run at Lambertsville, Pa., Site 812 (LAT 4004 14N LONG $0785451 \mathrm{~W}$ ) } \\
\hline September 1, 1992 & 1135 & 2.6 & 14.0 & 2,330 & 6.7 & 28 & 2,360 & 5.9 & 1,500 \\
\hline July 27, 1993 & 1420 & 3.9 & 20.5 & 2,550 & 6.6 & 14 & 2,450 & 3.1 & 1,800 \\
\hline May 23, 1994 & 2000 & 7.2 & 18.0 & 2,350 & 6.1 & 30 & 2,450 & 6.5 & 1,800 \\
\hline \multicolumn{10}{|c|}{400611078555801 Stonycreek River at Kantner, Pa., Site 802 (LAT 4006 11N LONG 07855 58W) } \\
\hline September 2, 1992 & 1000 & 35 & 13.5 & 650 & 6.0 & 42 & 564 & 8.3 & 260 \\
\hline July 27, 1993 & 1140 & 23 & 23.5 & 884 & 7.2 & 42 & 678 & 9.1 & 420 \\
\hline May 23, 1994 & 1620 & 91 & 20.0 & 567 & 7.6 & 22 & 470 & 4.5 & 260 \\
\hline \multicolumn{10}{|c|}{400701078481601 Laurel Run at Central City, Pa., Site 825 (LAT $400701 N$ LONG 07848 16W) } \\
\hline September 1, 1992 & 1710 & 7.2 & 17.5 & 137 & 6.1 & 8 & 144 & 2.0 & 44 \\
\hline July 28, 1993 & 1200 & 2.0 & 20.5 & 229 & 5.0 & 3 & 192 & 1.9 & 120 \\
\hline May 23, 1994 & 1400 & 10 & 16.0 & 99 & 5.1 & 2 & 106 & $<1.0$ & 38 \\
\hline
\end{tabular}




\begin{tabular}{|c|c|c|c|c|c|c|c|c|c|}
\hline Date & $\begin{array}{c}\text { Fluoride, } \\
\text { total } \\
(\mathrm{mg} / \mathrm{L} \\
\text { as F) }\end{array}$ & $\begin{array}{l}\text { Iron, total } \\
\text { recoverable } \\
(\mu \mathrm{g} / \mathrm{L} \\
\text { as Fe })\end{array}$ & $\begin{array}{c}\text { Iron, } \\
\text { dissolved } \\
(\mu \mathrm{g} / \mathrm{L} \\
\text { as Fe })\end{array}$ & $\begin{array}{c}\text { Manganese, } \\
\text { total } \\
\text { recoverable } \\
(\mu \mathrm{g} / \mathrm{L} \\
\text { as } \mathrm{Mn})\end{array}$ & $\begin{array}{c}\text { Manganese, } \\
\text { dissolved } \\
(\mu \mathrm{g} / \mathrm{L} \\
\text { as } \mathrm{Mn})\end{array}$ & $\begin{array}{l}\text { Aluminum, } \\
\text { total } \\
\text { recoverable } \\
(\mu \mathrm{g} / \mathrm{L} \\
\text { as } \mathrm{Al})\end{array}$ & $\begin{array}{l}\text { Aluminum, } \\
\text { dissolved } \\
(\mu \mathrm{g} / \mathrm{L} \\
\text { as Al }\end{array}$ & $\begin{array}{l}\text { Acidity, } \\
\text { total } \\
\text { heated } \\
(\mathrm{mg} / \mathrm{L} \text { as } \\
\left.\mathrm{CaCO}_{3}\right)\end{array}$ & $\begin{array}{c}\text { Acidity, } \\
\text { mineral } \\
\text { (methyl } \\
\text { orange) } \\
(\mathrm{mg} / \mathrm{L} \text { as } \\
\left.\mathrm{CaCO}_{3}\right)\end{array}$ \\
\hline \multicolumn{10}{|c|}{03039957 Bens Creek at Ferndale, Pa., Site 834 (LAT 4016 58N LONG 07856 10W) } \\
\hline September 1, 1992 & $<0.2$ & 80 & $<10$ & $<10$ & $<10$ & $<130$ & $<130$ & 0 & 0 \\
\hline July 28, 1993 & $<.2$ & 210 & 30 & $<50$ & $<50$ & 200 & 160 & 0 & -- \\
\hline May 23, 1994 & $<.2$ & 270 & $<10$ & 56 & 40 & 250 & $<130$ & 0 & -- \\
\hline \multicolumn{10}{|c|}{03040000 Stonycreek River at Ferndale, Pa., Site 805 (LAT 4017 08N LONG 07855 15W) } \\
\hline September 1, 1992 & $<.2$ & 1,200 & 630 & 1,300 & 1,200 & 990 & 640 & 15 & 0 \\
\hline July 27, 1993 & $<.2$ & 1,000 & 340 & 2,600 & 2,500 & 4,700 & 4,400 & 34 & -- \\
\hline May 23, 1994 & $<.2$ & 1,700 & 630 & 1,400 & 1,400 & 1,800 & 1,100 & 16 & -- \\
\hline \multicolumn{10}{|c|}{395836078554901 Glades Creek near Shanksville, Pa., Site 806 (LAT 3958 36N LONG 07855 49W) } \\
\hline September 1, 1992 & $<.2$ & 420 & 37 & 400 & 380 & $<130$ & $<130$ & 0 & 0 \\
\hline July 27, 1993 & $<.2$ & 960 & 50 & 600 & 600 & 1,000 & 100 & 0 & -- \\
\hline May 24, 1994 & $<.2$ & 460 & 77 & 930 & 820 & 290 & $<130$ & 0 & -- \\
\hline \multicolumn{10}{|c|}{ 400014078540201 Stonycreek River at Shanksville, Pa., Site 801 (LAT 4000 14N LONG $0785402 W$ ) } \\
\hline September 1, 1992 & $<.2$ & 1,000 & 83 & 450 & 210 & 820 & 130 & 0 & 0 \\
\hline July 27, 1993 & $<.2$ & 500 & 40 & 500 & 440 & 330 & $<100$ & 0 & -- \\
\hline May 24, 1994 & $<.2$ & 390 & 220 & 820 & 780 & $<130$ & $<130$ & 0 & -- \\
\hline \multicolumn{10}{|c|}{400033078511601 Boone Run near Shanksville, Pa., Site 807 (LAT 4000 33N LONG 07851 16W) } \\
\hline September 1, 1992 & $<.2$ & 1,500 & 720 & 290 & 290 & 340 & $<130$ & 8.6 & 0 \\
\hline July 27, 1993 & $<.2$ & 3,900 & 2,700 & 1,200 & 1,200 & 1,200 & 400 & 12 & -- \\
\hline May 23, 1994 & $<.2$ & 990 & 720 & 360 & 390 & 630 & 440 & 12 & -- \\
\hline \multicolumn{10}{|c|}{400056078540501 Rhoads Creek at Shanksville, Pa., Site 810 (LAT 4000 56N LONG 07854 05W) } \\
\hline September 1, 1992 & $<.2$ & 140 & 100 & 81 & 57 & 1,300 & 1,300 & 0 & 0 \\
\hline July 27, 1993 & $<.2$ & 120 & 14 & 130 & 130 & $<100$ & $<100$ & 0 & -- \\
\hline May 24, 1994 & $<.2$ & 160 & 21 & 1,000 & 880 & $<130$ & $<130$ & 0 & -- \\
\hline \multicolumn{10}{|c|}{400058078552301 Schrock Run near Shanksville, Pa., Site 811 (LAT 4000 58N LONG 07855 23W) } \\
\hline September 1, 1992 & .2 & 5,400 & 130 & 2,500 & 2,200 & 3,200 & $<130$ & 0 & 0 \\
\hline July 27,1993 & $<.2$ & 5,800 & 2,800 & 6,000 & 5,800 & 2,800 & $<100$ & 0 & -- \\
\hline May 24, 1994 & $<.2$ & 1,300 & 590 & 4,000 & 3,600 & 660 & $<130$ & 0 & -- \\
\hline \multicolumn{10}{|c|}{400337078513701 Calendars Run at Buckstown, Pa., Site 809 (LAT 4003 37N LONG 07851 37W) } \\
\hline September 1, 1992 & $<.2$ & 160 & 45 & 170 & 160 & $<130$ & $<130$ & 0 & 0 \\
\hline July 28, 1993 & $<.2$ & 40 & 10 & 60 & $<50$ & $<100$ & $<100$ & 0 & -- \\
\hline May 23, 1994 & .2 & 310 & 100 & 820 & 730 & 600 & 180 & 0 & -- \\
\hline \multicolumn{10}{|c|}{400414078545101 Lamberts Run at Lambertsville, Pa., Site 812 (LAT 4004 14N LONG 0785451 W) } \\
\hline September 1, 1992 & $<.2$ & 930 & 81 & 1,300 & 1,200 & 440 & $<130$ & 0 & 0 \\
\hline July 27, 1993 & $<.2$ & 1,800 & 140 & 1,500 & 1,300 & 1,000 & 170 & 0 & -- \\
\hline May 23, 1994 & $<.2$ & 3,700 & 300 & 3,400 & 3,100 & 1,300 & 250 & 0 & -- \\
\hline \multicolumn{10}{|c|}{400611078555801 Stonycreek River at Kantner, Pa., Site 802 (LAT 4006 11N LONG 07855 58W) } \\
\hline September 2, 1992 & $<.2$ & 160 & 61 & 75 & 65 & 240 & 150 & 0 & 0 \\
\hline July 27, 1993 & $<.2$ & 240 & 20 & 170 & 100 & 240 & 200 & 0 & -- \\
\hline May 23, 1994 & $<.2$ & 180 & $<10$ & 450 & 400 & 370 & 290 & 0 & -- \\
\hline \multicolumn{10}{|c|}{400701078481601 Laurel Run at Central City, Pa., Site 825 (LAT $400701 N$ LONG 07848 16W) } \\
\hline September 1, 1992 & $<.2$ & 2,300 & 620 & 590 & 540 & 1,900 & $<130$ & 7.4 & 0 \\
\hline July 28, 1993 & $<.2$ & 2,700 & 2,100 & 1,000 & 1,000 & 800 & $<100$ & 11 & -- \\
\hline May 23, 1994 & $<.2$ & 760 & 640 & 480 & 500 & 670 & 360 & 0 & -- \\
\hline
\end{tabular}




\begin{tabular}{|c|c|c|c|c|c|c|c|c|c|}
\hline Date & Time & $\begin{array}{c}\text { Discharge, } \\
\text { instantaneous } \\
\left(\mathrm{ft}^{3} / \mathrm{s}\right)\end{array}$ & $\begin{array}{c}\text { Temperature, } \\
\text { water } \\
\left({ }^{\circ} \mathrm{C}\right)\end{array}$ & $\begin{array}{c}\text { Specific } \\
\text { conductance } \\
(\mu \mathrm{S} / \mathrm{cm})\end{array}$ & $\begin{array}{c}\mathrm{pH} \\
\text { (standard } \\
\text { units) }\end{array}$ & $\begin{array}{c}\text { Alkalinity, } \\
\text { total } \\
(\mathrm{mg} / \mathrm{L} \text { as } \\
\left.\mathrm{CaCO}_{3}\right)\end{array}$ & $\begin{array}{c}\text { Residue } \\
\text { at } 105^{\circ} \mathrm{C}, \\
\text { dissolved } \\
(\mathrm{mg} / \mathrm{L})\end{array}$ & $\begin{array}{l}\text { Carbon, } \\
\text { inorganic, } \\
\text { total } \\
(\mathrm{mg} / \mathrm{L} \\
\text { as C) }\end{array}$ & $\begin{array}{c}\text { Sulfate, } \\
\text { total } \\
(\mathrm{mg} / \mathrm{L} \\
\left.\text { as } \mathrm{SO}_{4}\right)\end{array}$ \\
\hline \multicolumn{10}{|c|}{400706078552801 Oven Run at Rowena, Pa., Site 815 (LAT 4007 06N LONG 07855 28W) } \\
\hline September 2, 1992 & 1100 & 0.57 & 13.0 & 1,930 & 2.7 & 0 & 2,130 & $<1.0$ & 1,100 \\
\hline July 27, 1993 & 1700 & .55 & 23.5 & 2,350 & 2.8 & 0 & 2,740 & $<1.0$ & 2,000 \\
\hline May 24, 1994 & 1020 & 3.1 & 12.5 & 1,320 & 3.2 & 0 & 1,240 & $<1.0$ & 820 \\
\hline \multicolumn{10}{|c|}{400738078552801 Pokeytown Run at Wilbur Pa., Site 837 (LAT 4007 38N LONG 07855 28W) } \\
\hline July 27, 1993 & 1610 & .68 & 19.0 & 2,960 & 2.9 & 0 & 3,970 & $<1.0$ & 3,500 \\
\hline SEP 08... & 1100 & .40 & 15.0 & 3,510 & 2.7 & 0 & 6,370 & $<1.0$ & 4,100 \\
\hline May 24, 1994 & 1100 & 2.0 & 14.5 & 1,670 & 3.1 & 0 & 2,090 & 1.0 & 1,400 \\
\hline \multicolumn{10}{|c|}{400822079035901 North Branch Quemahoning Creek near Coal Junction, Pa., Site 820 (LAT 4008 22N LONG 07903 59W) } \\
\hline September 1, 1992 & 0830 & 6.9 & 15.0 & 124 & 6.4 & 13 & 148 & 3.3 & 30 \\
\hline July 27, 1993 & 0845 & 1.8 & 21.0 & 135 & 6.3 & 15 & 116 & 4.7 & 35 \\
\hline May 23, 1994 & 0840 & 30 & 13.0 & 87 & 5.5 & 6 & 90 & 2.0 & 25 \\
\hline \multicolumn{10}{|c|}{400826078580401 Higgins Run near Boswell, Pa., Site 823 (LAT 4008 26N LONG 07858 04W) } \\
\hline September 1, 1992 & 1640 & 2.0 & 14.5 & 970 & 6.6 & 86 & 828 & 16 & 460 \\
\hline July 28, 1993 & 1430 & 3.0 & 17.5 & 910 & 6.3 & 86 & 736 & 18 & 420 \\
\hline May 23, 1994 & 1500 & 6.3 & 15.5 & 620 & 7.4 & 60 & 514 & 2.3 & 250 \\
\hline \multicolumn{10}{|c|}{400841078544901 Fallen Timber Run at Hooversville, Pa., Site 816 (LAT 4008 41N LONG 07854 49W) } \\
\hline September 1, 1992 & 1815 & .32 & 13.5 & 502 & 5.3 & 3 & 498 & 1.6 & 270 \\
\hline July 27, 1993 & 1500 & .30 & 17.0 & 457 & 5.0 & 2 & 422 & 1.0 & 320 \\
\hline May 24, 1994 & 1200 & 1.2 & 12.0 & 310 & 5.5 & 4 & 294 & 2.9 & 160 \\
\hline \multicolumn{10}{|c|}{400854078490201 Clear Shade Creek at Reitz, Pa., Site 827 (LAT 4008 54N LONG 07849 02W) } \\
\hline September 2, 1992 & 0915 & 34 & 12.5 & 42 & 5.9 & 4 & 90 & $<1.0$ & 10 \\
\hline July 28, 1993 & 0850 & 7.1 & 20.5 & 57 & 6.3 & 10 & 94 & 2.4 & 8.4 \\
\hline May 23, 1994 & 1140 & 75 & 14.5 & 40 & 5.4 & 4 & 48 & $<1.0$ & 93 \\
\hline \multicolumn{10}{|c|}{400908078585701 Twomile Run near Boswell, Pa., Site 822 (LAT 4009 08N LONG 07858 57W) } \\
\hline September 1, 1992 & 1600 & .52 & 16.0 & 510 & 5.4 & 3 & 514 & $<1.0$ & 240 \\
\hline July 28, 1993 & 1315 & .48 & 21.0 & 662 & 6.2 & 12 & 592 & $<1.0$ & 320 \\
\hline May 23, 1994 & 1410 & 4.3 & 18.0 & 490 & 6.7 & 6 & 458 & 1.2 & 230 \\
\hline \multicolumn{10}{|c|}{400954079040501 Beaverdam Creek at Jennerstown, Pa., Site 819 (LAT 4009 54N LONG $0790405 W$ ) } \\
\hline September 1, 1992 & 1000 & 2.3 & 13.5 & 97 & 6.5 & 28 & 124 & 6.2 & 10 \\
\hline July 28, 1993 & 1015 & 1.5 & 19.5 & 208 & 6.1 & 34 & 156 & 8.3 & 43 \\
\hline May 23, 1994 & 1025 & 9.8 & 12.5 & 86 & 6.9 & 12 & 64 & 3.1 & 21 \\
\hline \multicolumn{10}{|c|}{401017079005301 Roaring Run at Pilltown, Pa., Site 821 (LAT 4010 17N LONG 07900 53W) } \\
\hline September 1, 1992 & 1200 & 3.5 & 16.5 & 282 & 6.1 & 24 & 292 & 5.6 & 97 \\
\hline July 28, 1993 & 1230 & 1.0 & 22.5 & 872 & 6.1 & 46 & 706 & 12 & 430 \\
\hline May 23, 1994 & 1250 & 17 & 19.5 & 250 & 6.8 & 20 & 206 & 5.5 & 91 \\
\hline \multicolumn{10}{|c|}{401018078542901 Stonycreek River at Blough, Pa., Site 803 (LAT 4010 18N LONG 07854 29W) } \\
\hline September 1, 1992 & 1745 & 51 & 21.5 & 660 & 5.4 & 11 & 576 & $<1.0$ & 310 \\
\hline July 27, 1993 & 1310 & 23 & 27.0 & 1,100 & 3.8 & 0 & 896 & $<1.0$ & 720 \\
\hline May 23, 1994 & 1730 & 122 & 20.5 & 617 & 6.8 & 5 & 498 & 1.2 & 310 \\
\hline \multicolumn{10}{|c|}{401059078495201 Roaring Fork near Hillsboro, Pa., Site 828 (LAT 4010 59N LONG 07849 52W) } \\
\hline September 2, 1992 & 1025 & 4.8 & 13.5 & 142 & 4.5 & 0 & 162 & $<1.0$ & 50 \\
\hline July 28, 1993 & 0730 & 1.8 & 19.0 & 203 & 3.5 & 0 & 142 & $<1.0$ & 120 \\
\hline May 23, 1994 & 1240 & 13 & 13.5 & 80 & 5.0 & 1 & 74 & $<1.0$ & 28 \\
\hline
\end{tabular}




\begin{tabular}{|c|c|c|c|c|c|c|c|c|c|}
\hline Date & $\begin{array}{c}\text { Fluoride, } \\
\text { total } \\
(\mathrm{mg} / \mathrm{L} \\
\text { as F) }\end{array}$ & $\begin{array}{c}\text { Iron, total } \\
\text { recoverable } \\
(\mu \mathrm{g} / \mathrm{L} \\
\text { as Fe })\end{array}$ & $\begin{array}{c}\text { Iron, } \\
\text { dissolved } \\
(\mu \mathrm{g} / \mathrm{L} \\
\text { as Fe })\end{array}$ & $\begin{array}{c}\text { Manganese, } \\
\text { total } \\
\text { recoverable } \\
(\mu \mathrm{g} / \mathrm{L} \\
\text { as } \mathrm{Mn})\end{array}$ & $\begin{array}{c}\text { Manganese, } \\
\text { dissolved } \\
(\mu \mathrm{g} / \mathrm{L} \\
\text { as } \mathrm{Mn})\end{array}$ & $\begin{array}{l}\text { Aluminum, } \\
\text { total } \\
\text { recoverable } \\
(\mu \mathrm{g} / \mathrm{L} \\
\text { as } \mathrm{Al})\end{array}$ & $\begin{array}{l}\text { Aluminum, } \\
\text { dissolved } \\
(\mu \mathrm{g} / \mathrm{L} \\
\text { as Al }\end{array}$ & $\begin{array}{c}\text { Acidity, } \\
\text { total } \\
\text { heated } \\
(\mathrm{mg} / \mathrm{L} \text { as } \\
\left.\mathrm{CaCO}_{3}\right)\end{array}$ & $\begin{array}{l}\text { Acidity, } \\
\text { mineral } \\
\text { (methyl } \\
\text { orange) } \\
(\mathrm{mg} / \mathrm{L} \text { as } \\
\left.\mathrm{CaCO}_{3}\right)\end{array}$ \\
\hline \multicolumn{10}{|c|}{400706078552801 Oven Run at Rowena, Pa., Site 815 (LAT 4007 06N LONG 07855 28W) } \\
\hline September 2, 1992 & 0.8 & 23,000 & 23,000 & 21,000 & 21,000 & 26,000 & 26,000 & 350 & 124 \\
\hline July 27, 1993 & .5 & 21,000 & 19,000 & 39,000 & 36,000 & 46,000 & 42,000 & 450 & 136 \\
\hline May 24, 1994 & .5 & 15,000 & 15,000 & 15,000 & 15,000 & 19,000 & 18,000 & 190 & 66 \\
\hline \multicolumn{10}{|c|}{400738078552801 Pokeytown Run at Wilbur Pa., Site 837 (LAT 4007 38N LONG 07855 28W) } \\
\hline July 27, 1993 & 1.1 & 400,000 & 400,000 & 14,000 & 14,000 & 140,000 & 140,000 & 1,740 & 670 \\
\hline SEP 08... & 1.7 & 490,000 & 520,000 & 14,000 & 13,000 & 190,000 & 180,000 & 2,180 & 650 \\
\hline May 24, 1994 & .6 & 100,000 & 100,000 & 6,700 & 6,700 & 55,000 & 55,000 & 528 & 166 \\
\hline \multicolumn{10}{|c|}{400822079035901 North Branch Quemahoning Creek near Coal Junction, Pa., Site 820 (LAT 4008 22N LONG 07903 59W) } \\
\hline September 1, 1992 & $<.2$ & 1,100 & 40 & 380 & 370 & 210 & $<130$ & 0 & 0 \\
\hline July 27,1993 & $<.2$ & 1,700 & 160 & 320 & 320 & 200 & $<100$ & 0 & -- \\
\hline May 23, 1994 & $<.2$ & 580 & 250 & 330 & 350 & 180 & $<130$ & 4.0 & -- \\
\hline \multicolumn{10}{|c|}{400826078580401 Higgins Run near Boswell, Pa., Site 823 (LAT 4008 26N LONG 07858 04W) } \\
\hline September 1, 1992 & $<.2$ & 160 & $<10$ & 52 & 33 & $<130$ & $<130$ & 0 & 0 \\
\hline July 28, 1993 & $<.2$ & 210 & 24 & 110 & 59 & 200 & $<100$ & 0 & -- \\
\hline May 23, 1994 & $<.2$ & 440 & $<10$ & 160 & 130 & 260 & 140 & 0 & -- \\
\hline \multicolumn{10}{|c|}{400841078544901 Fallen Timber Run at Hooversville, Pa., Site 816 (LAT 4008 41N LONG 07854 49W) } \\
\hline September 1, 1992 & .3 & 490 & 50 & 710 & 670 & 1,300 & 720 & 20 & 0 \\
\hline July 27, 1993 & .3 & 100 & 90 & 570 & 570 & 1,200 & 600 & 9.6 & -- \\
\hline May 24, 1994 & $<.2$ & 250 & 52 & 280 & 240 & 740 & 260 & 1.4 & -- \\
\hline \multicolumn{10}{|c|}{400854078490201 Clear Shade Creek at Reitz, Pa., Site 827 (LAT 4008 54N LONG 07849 02W) } \\
\hline September 2, 1992 & $<.2$ & 140 & 48 & 53 & 43 & 170 & $<130$ & 7.2 & 0 \\
\hline July 28,1993 & $<.2$ & 140 & 100 & $<50$ & $<50$ & $<100$ & $<100$ & 0 & -- \\
\hline May 23, 1994 & $<.2$ & 140 & 85 & 88 & 80 & 190 & $<130$ & 6.2 & -- \\
\hline \multicolumn{10}{|c|}{400908078585701 Twomile Run near Boswell, Pa., Site 822 (LAT 4009 08N LONG 07858 57W) } \\
\hline September 1, 1992 & $<.2$ & 120 & 50 & 2,900 & 2,800 & 860 & 730 & 13 & 0 \\
\hline July 28, 1993 & $<.2$ & 140 & 40 & 2,200 & 2,200 & 760 & 700 & 7.6 & -- \\
\hline May 23, 1994 & $<.2$ & 390 & $<10$ & 2,100 & 2,100 & 800 & $<130$ & 6.2 & -- \\
\hline \multicolumn{10}{|c|}{400954079040501 Beaverdam Creek at Jennerstown, Pa., Site 819 (LAT 4009 54N LONG $0790405 W$ ) } \\
\hline September 1, 1992 & $<.2$ & 290 & 130 & 90 & 84 & 140 & $<130$ & 0 & 0 \\
\hline July 28, 1993 & $<.2$ & 600 & 28 & 330 & 290 & 200 & $<100$ & 0 & -- \\
\hline May 23, 1994 & $<.2$ & 450 & 80 & 190 & 160 & 170 & $<130$ & 0 & -- \\
\hline \multicolumn{10}{|c|}{401017079005301 Roaring Run at Pilltown, Pa., Site 821 (LAT 4010 17N LONG 07900 53W) } \\
\hline September 1, 1992 & $<.2$ & 2,600 & 1,500 & 820 & 820 & 180 & $<130$ & 0 & 0 \\
\hline July 28, 1993 & .2 & 4,500 & 1,200 & 2,200 & 2,200 & 200 & $<130$ & 0 & -- \\
\hline May 23, 1994 & $<.2$ & 2,100 & 890 & 620 & 600 & 370 & $<130$ & 0 & -- \\
\hline \multicolumn{10}{|c|}{401018078542901 Stonycreek River at Blough, Pa., Site 803 (LAT 4010 18N LONG 07854 29W) } \\
\hline September 1, 1992 & $<.2$ & 1,200 & 270 & 1,100 & 1,100 & 710 & 140 & 7.0 & 0 \\
\hline July 27, 1993 & .2 & 1,700 & 490 & 2,800 & 2,800 & 7,500 & 7,500 & 62 & 5 \\
\hline May 23, 1994 & $<.2$ & 2,700 & 410 & 1,300 & 1,300 & 1,800 & $<130$ & 7.8 & -- \\
\hline \multicolumn{10}{|c|}{401059078495201 Roaring Fork near Hillsboro, Pa., Site 828 (LAT 4010 59N LONG 07849 52W) } \\
\hline September 2, 1992 & $<.2$ & 500 & 380 & 1,100 & 1,100 & 680 & 680 & 15 & 0 \\
\hline July 28, 1993 & $<.2$ & 1,000 & 750 & 1,400 & 1,400 & 700 & 700 & 16 & -- \\
\hline May 23, 1994 & $<.2$ & 240 & 170 & 440 & 450 & 540 & 510 & 11 & -- \\
\hline
\end{tabular}


Appendix 5. Field data and laboratory analyses for surface-water sites-Continued

\begin{tabular}{|c|c|c|c|c|c|c|c|c|c|}
\hline Date & Time & $\begin{array}{c}\text { Discharge, } \\
\text { instantaneous } \\
\left(\mathrm{ft}^{3} / \mathrm{s}\right)\end{array}$ & $\begin{array}{l}\text { Temperature, } \\
\text { water } \\
\left({ }^{\circ} \mathrm{C}\right)\end{array}$ & $\begin{array}{c}\text { Specific } \\
\text { conductance } \\
(\mu \mathrm{S} / \mathrm{cm})\end{array}$ & $\begin{array}{c}\mathrm{pH} \\
\text { (standard } \\
\text { units) }\end{array}$ & $\begin{array}{c}\text { Alkalinity, } \\
\text { total } \\
(\mathrm{mg} / \mathrm{L} \text { as } \\
\left.\mathrm{CaCO}_{3}\right)\end{array}$ & $\begin{array}{c}\text { Residue } \\
\text { at } 105^{\circ} \mathrm{C} \text {, } \\
\text { dissolved } \\
(\mathrm{mg} / \mathrm{L})\end{array}$ & $\begin{array}{c}\text { Carbon, } \\
\text { inorganic, } \\
\text { total } \\
(\mathrm{mg} / \mathrm{L} \\
\text { as C) }\end{array}$ & $\begin{array}{c}\text { Sulfate, } \\
\text { total } \\
(\mathrm{mg} / \mathrm{L} \\
\left.\text { as } \mathrm{SO}_{4}\right)\end{array}$ \\
\hline \multicolumn{10}{|c|}{401121078562801 Quemahoning Creek at Quemahoning Reservoir Outflow, Site 817 (LAT 401121 L LONG $0785628 W$ ) } \\
\hline September 1, 1992 & 1500 & 13 & 25.0 & 266 & 5.5 & 18 & 260 & 3.4 & 84 \\
\hline July 27,1993 & 1900 & .09 & 26.0 & 206 & 7.1 & 50 & 146 & 11 & 35 \\
\hline May 23, 1994 & 1915 & 74 & 20.0 & 201 & 7.2 & 12 & 192 & 2.3 & 64 \\
\hline \multicolumn{10}{|c|}{ 401243078535501 Shade Creek at Seanor, Pa., Site 836 (LAT 4012 43N LONG 07853 55W) } \\
\hline September 1, 1992 & 1610 & 80 & 18.5 & 322 & 4.5 & 0 & 282 & $<1.0$ & 140 \\
\hline July 28, 1993 & 1700 & 40 & 27.5 & 670 & 3.5 & 0 & 474 & $<1.0$ & 410 \\
\hline May 24, 1994 & 1030 & 137 & 13.5 & 300 & 3.8 & 0 & 228 & $<1.0$ & 130 \\
\hline \multicolumn{10}{|c|}{401437078530201 Stonycreek River near Windber, Pa., Site 804 (LAT 4014 37N LONG 07853 02W) } \\
\hline September 2, 1992 & 1220 & 122 & 17.5 & 456 & 5.5 & 2 & 402 & $<1.0$ & 210 \\
\hline July 28,1993 & 1520 & 77 & 27.5 & 840 & 3.9 & 0 & 654 & $<1.0$ & 550 \\
\hline May 24, 1994 & 1330 & 386 & 17.0 & 390 & 5.2 & 2 & 334 & $<1.0$ & 170 \\
\hline \multicolumn{10}{|c|}{401441078530201 Paint Creek near Windber, Pa., Site 830 (LAT 4014 41N LONG 07853 02W) } \\
\hline September 2, 1992 & 1105 & 14 & 14.0 & 1,220 & 3.6 & 0 & 1,210 & $<1.0$ & 720 \\
\hline July 28, 1993 & 1420 & 9.9 & 24.5 & 1,380 & 3.4 & 0 & 1,210 & $<1.0$ & 960 \\
\hline May 24, 1994 & 1400 & 43 & 17.0 & 800 & 3.6 & 0 & 732 & 3.0 & 510 \\
\hline \multicolumn{10}{|c|}{401821078543601 Solomon Run at Johnstown, Pa., Site 835 (LAT 4018 21N LONG 07854 36W) } \\
\hline September 1, 1992 & 1320 & 22 & 23.0 & 1,080 & 6.0 & 5 & 1,020 & 1.3 & 550 \\
\hline July 27, 1993 & 1515 & 2.6 & 27.0 & 1,150 & 6.6 & 7 & 914 & 2.7 & 560 \\
\hline May 23, 1994 & 1845 & 6.8 & 18.0 & 770 & 6.8 & 24 & 690 & 9.1 & 330 \\
\hline
\end{tabular}


Appendix 5. Field data and laboratory analyses for surface-water sites-Continued

\begin{tabular}{|c|c|c|c|c|c|c|c|c|c|}
\hline Date & $\begin{array}{c}\text { Fluoride, } \\
\text { total } \\
\text { (mg/L } \\
\text { as F) }\end{array}$ & $\begin{array}{c}\text { Iron, total } \\
\text { recoverable } \\
(\mu \mathrm{g} / \mathrm{L} \\
\text { as Fe })\end{array}$ & $\begin{array}{c}\text { Iron, } \\
\text { dissolved } \\
(\mu \mathrm{g} / \mathrm{L} \\
\text { as Fe })\end{array}$ & $\begin{array}{c}\text { Manganese, } \\
\text { total } \\
\text { recoverable } \\
(\mu \mathrm{g} / \mathrm{L} \\
\text { as } \mathrm{Mn})\end{array}$ & $\begin{array}{c}\text { Manganese, } \\
\text { dissolved } \\
(\mu \mathrm{g} / \mathrm{L} \\
\text { as } \mathrm{Mn})\end{array}$ & $\begin{array}{l}\text { Aluminum, } \\
\text { total } \\
\text { recoverable } \\
(\mu \mathrm{g} / \mathrm{L} \\
\text { as } \mathrm{Al})\end{array}$ & $\begin{array}{c}\text { Aluminum, } \\
\text { dissolved } \\
(\mu \mathrm{g} / \mathrm{L} \\
\text { as Al }\end{array}$ & $\begin{array}{c}\text { Acidity, } \\
\text { total } \\
\text { heated } \\
(\mathrm{mg} / \mathrm{L} \text { as } \\
\left.\mathrm{CaCO}_{3}\right)\end{array}$ & $\begin{array}{c}\text { Acidity, } \\
\text { mineral } \\
\text { (methyl } \\
\text { orange) } \\
(\mathrm{mg} / \mathrm{L} \text { as } \\
\left.\mathrm{CaCO}_{3}\right)\end{array}$ \\
\hline \multicolumn{10}{|c|}{401121078562801 Quemahoning Creek at Quemahoning Reservoir Outflow, Site 817 (LAT 4011 21N LONG $0785628 W$ ) } \\
\hline September 1, 1992 & $<0.2$ & 40 & 16 & $<10$ & $<10$ & $<130$ & $<130$ & 0 & 0 \\
\hline July 27, 1993 & $<.2$ & 260 & 260 & 550 & 120 & 600 & $<100$ & 0 & -- \\
\hline May 23, 1994 & $<.2$ & 100 & $<10$ & 300 & 280 & $<130$ & $<130$ & 0 & -- \\
\hline \multicolumn{10}{|c|}{401243078535501 Shade Creek at Seanor, Pa., Site 836 (LAT 4012 43N LONG 07853 55W) } \\
\hline September 1, 1992 & $<.2$ & 1,800 & 1,500 & 1,200 & 1,200 & 1,600 & 1,600 & 28 & 1 \\
\hline July 28, 1993 & $<.2$ & 550 & 340 & 2,800 & 2,800 & 4,200 & 4,000 & 48 & 12 \\
\hline May 24, 1994 & $<.2$ & 1,600 & 860 & 1,300 & 1,200 & 2,000 & 1,900 & 19 & -- \\
\hline \multicolumn{10}{|c|}{401437078530201 Stonycreek River near Windber, Pa., Site 804 (LAT 4014 37N LONG $0785302 W$ ) } \\
\hline September 2, 1992 & $<.2$ & 850 & 500 & 1,100 & 1,100 & 1,200 & 1,100 & 14 & 0 \\
\hline July 28, 1993 & $<.2$ & 470 & 380 & 3,000 & 2,900 & 4,500 & 4,400 & 40 & 3 \\
\hline May 24, 1994 & $<.2$ & 1,200 & 410 & 970 & 910 & 1,100 & 340 & 6.2 & -- \\
\hline \multicolumn{10}{|c|}{401441078530201 Paint Creek near Windber, Pa., Site 830 (LAT 4014 41N LONG 07853 02W) } \\
\hline September 2, 1992 & .3 & 14,000 & 8,100 & 6,700 & 6,700 & 15,000 & 15,000 & 138 & 22 \\
\hline July 28, 1993 & .2 & 8,800 & 5,200 & 10,000 & 10,000 & 13,000 & 13,000 & 104 & 9 \\
\hline May 24, 1994 & .2 & 7,200 & 3,600 & 5,100 & 4,800 & 9,100 & 8,200 & 70 & 3 \\
\hline \multicolumn{10}{|c|}{401821078543601 Solomon Run at Johnstown, Pa., Site 835 (LAT $401821 \mathrm{~N}$ LONG 07854 36W) } \\
\hline September 1, 1992 & $<.2$ & 31,000 & 17,000 & 1,600 & 1,600 & 840 & $<130$ & 40 & 0 \\
\hline July 27, 1993 & $<.2$ & 17,000 & 8,200 & 2,700 & 2,700 & 1,800 & $<100$ & 11 & -- \\
\hline May 23, 1994 & $<.2$ & 11,000 & 4,200 & 820 & 780 & 1,100 & $<130$ & 0 & -- \\
\hline
\end{tabular}


